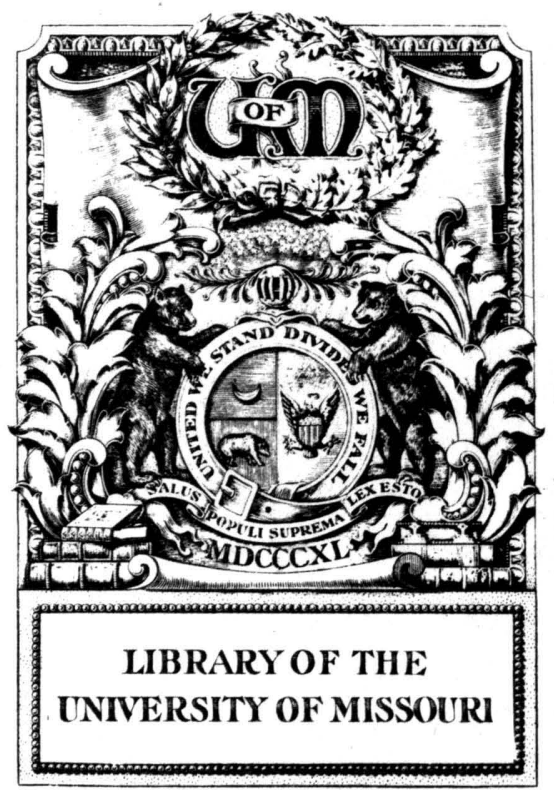




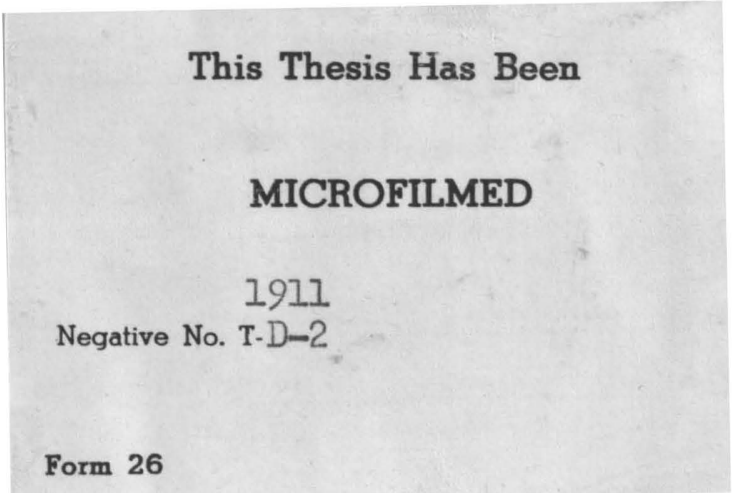




\title{
A STUDY \\ of the
}

CHEMICAL COMPOSITION OF STEERS

on

DIFTERENT PIANES OF NUTRITION

and of

THE RELATIVE COST

of

MAINTENANCE AND GROWTH

by

ROBERT MOULTON, 3. S., M. S. A.

\author{
SUBMITTED IN PARTIAL FULEILLMENT OF THE \\ REQUIREMENTS TPOR THE DEGREP OF \\ DOCTOR OF PHILOSOPHY \\ In $\operatorname{tin} \theta$ \\ GRADUATE DEPARTMENT \\ of tho \\ COLLEGE OF AGRICULTURE \\ of the \\ UNIVERSITY OF MISSOURI
}

JUNE, 1911. 

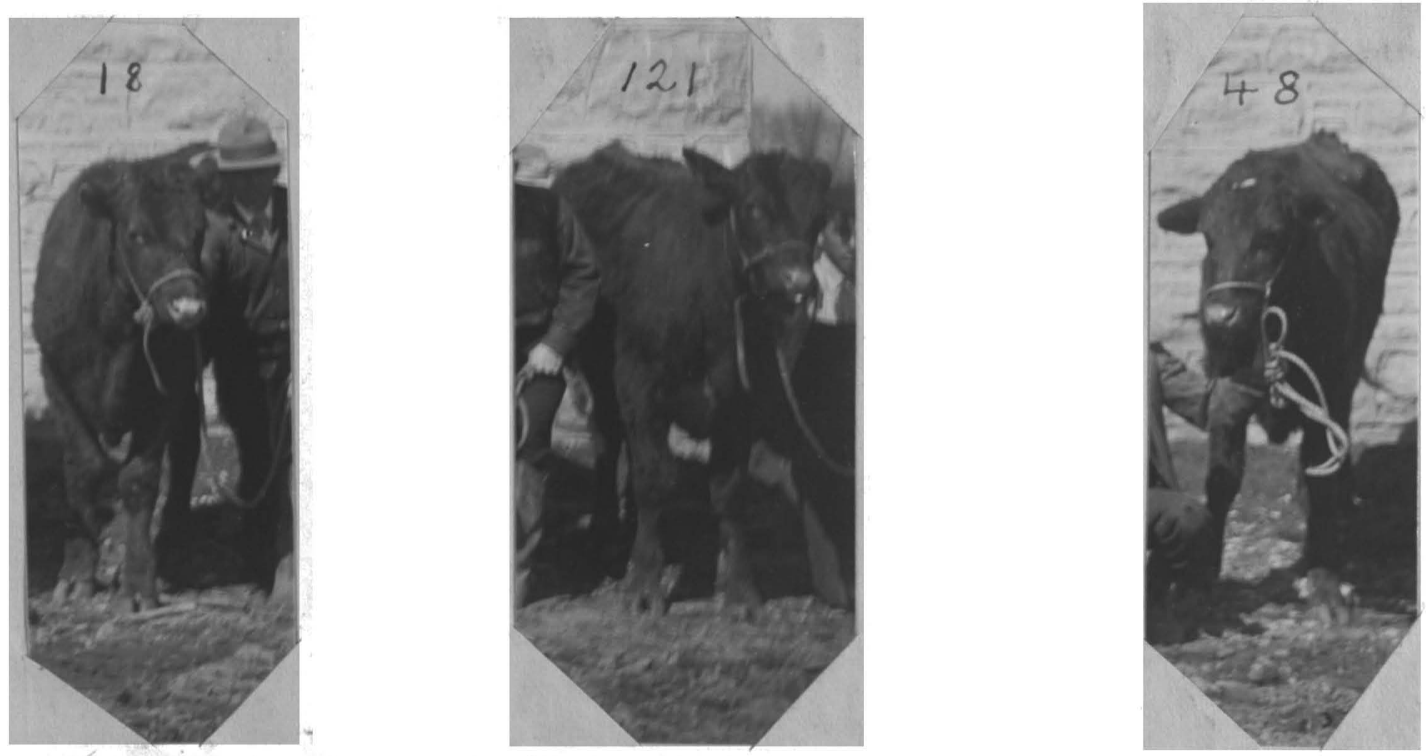

at feginming of experiment.
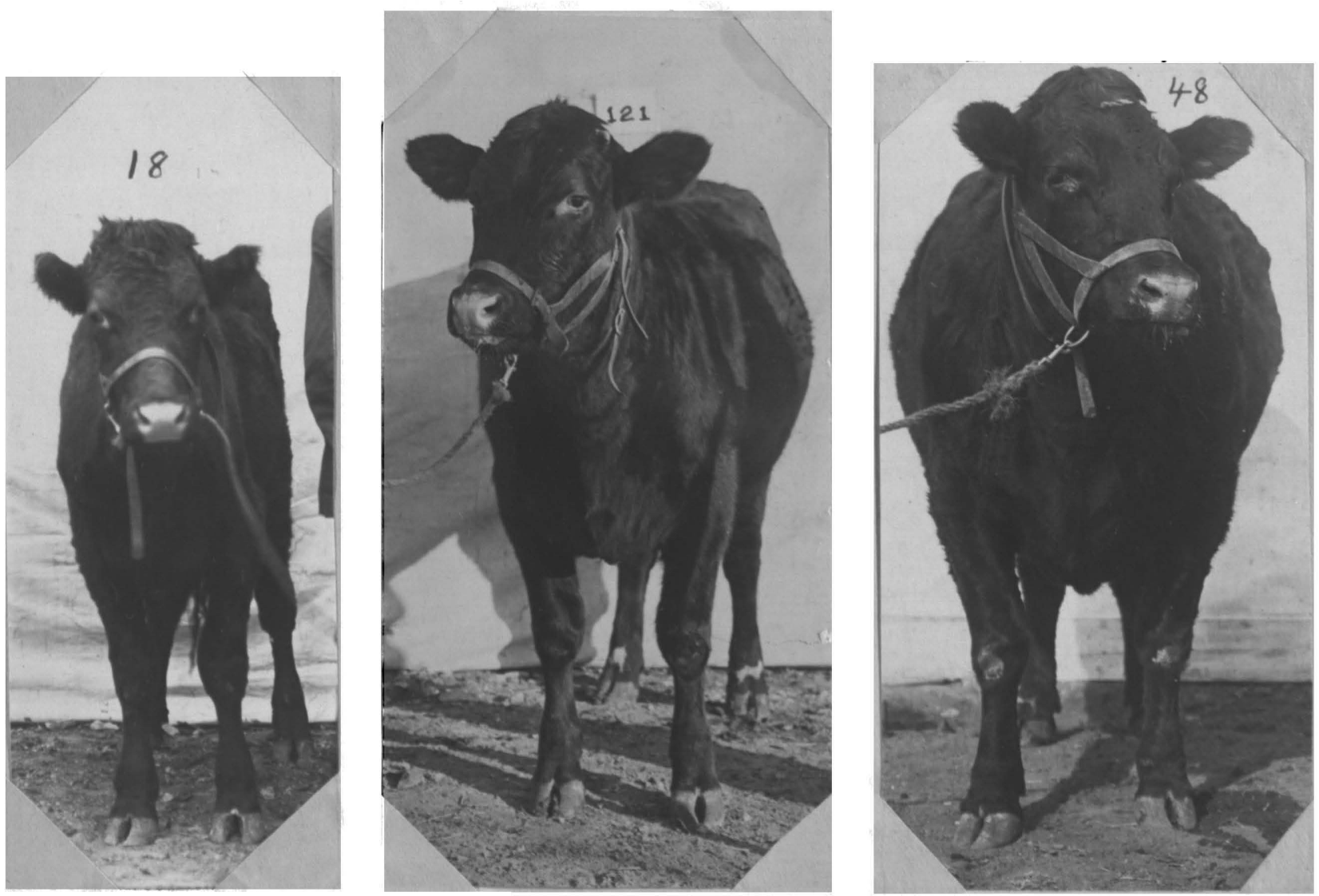

\section{3}

at the end of the experiment. 
. dis

$378.7 \mathrm{mmi}$

1911
$M 86$

TABLE OF COITEITS.

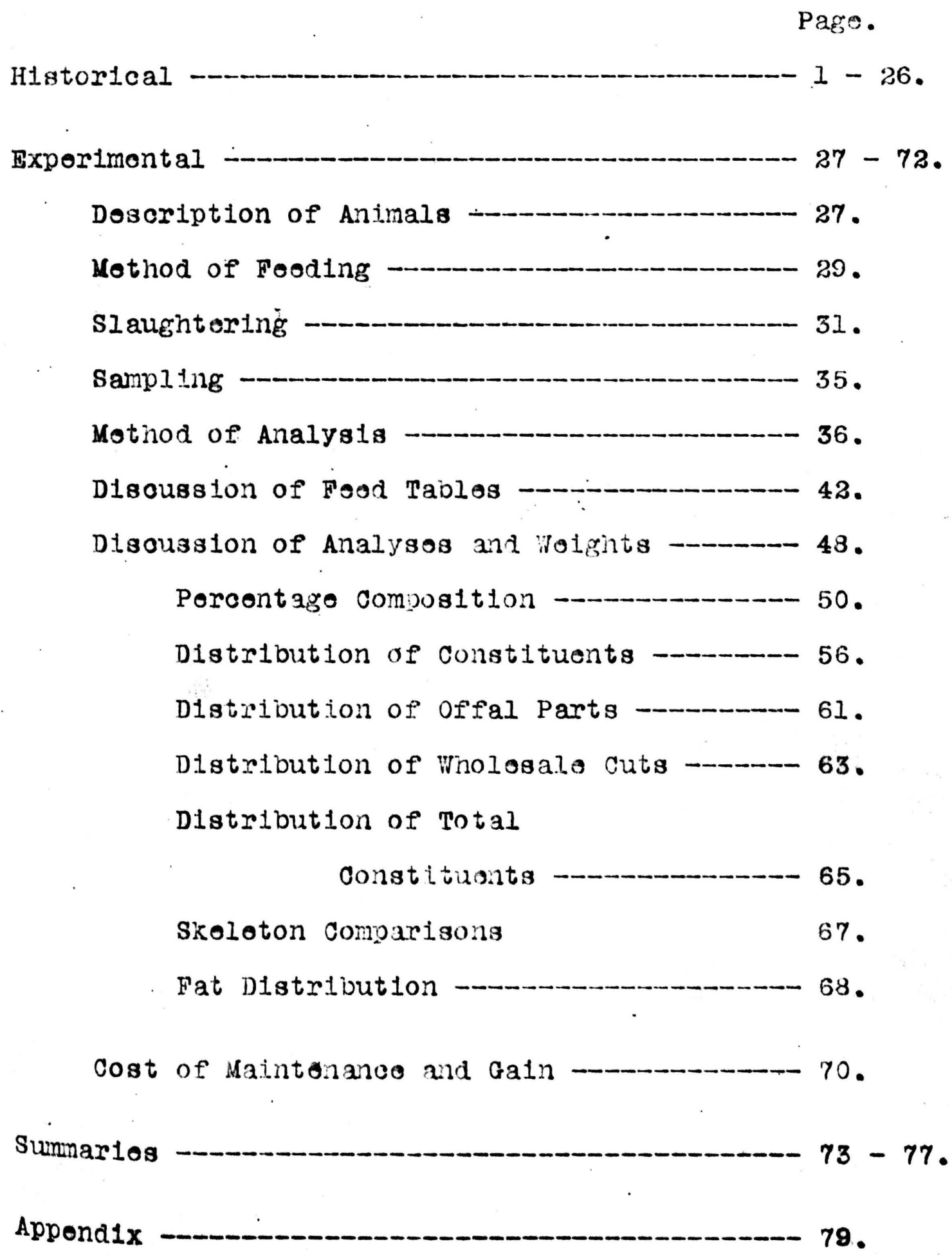




\section{HISTORICAL.}

The first classical work along the lines of investIgation with which this thesis is concornod was dono by Lawos and Gilbert at the Rothamsted Experiment station, England, about the midile of the nineteonth contury. (Phil. Trans., part 2, 1859; "Composition of AnImals", Rothamsted Expt. Sta., 1858.) Their work contains the analyses of one calf, two oxcn, ono lamb, four sheop, and two plgs, and tho fresh wolghts of the individual organs and other soparated parts of two calves, two holfors, fourtoon bullocks, two hundrod forty nino sheop, and fifty-nine pigs. A thorough disoussion is made of tho table for each constituent determinod, and also of the table giving the sumnary of the composition of the ten animals analyzed. The authors also give tables and discussion of the samo on tho rolation of the constituonts stored up in tho incroase to the constituents consumed in the food.

Anothor yapor, (Ph1l. Trans., 1883, p. 865) supplementary to the above publloation appoared in June 1883 and doalt wholly with the composition of the mineral matter of ontlro antmals analyzod and of tho separatod parts.

Theso authors used the so-called "fasted Iive wolght" for obtalning the porcontages of the welghts of the organs and parts to tho whole. Tho animal was kopt without food for elghteon to twonty-four hours, then wolghed just before being klliod. Th1s wolght constitutes the fasted 
live woight. This weight is open to the objection that wolght of the contents of the alimentary tract 1s.included, and this woight is a varying quantity.

In the analytloal work propor the problem was to keop the large number of samples from spolling until the matorial could bo analyzod. Thoy acoomplishod this by dryIng the samples at the temporature of boiling water, collooting thio fat which molted from the samples during this process, and also what oould be squeszed out through oloths. Tho residue still containing some fat but free from molsture Is oalled the orude dry substanoe, and th1s was subsequently ground and used for the determination of nitrogen, mineral matter, and the remaining fat. This operation was carried out separately for each organ and part of the offal and for each division of the carcass. The carcasses of the calves woro dividod Into throo parts: (I) flesh, fit, kiding and kldnoy mombrano; (2) kldnoy fat; (3) bones. Tho carcasses of the oxen wero divided into flve parts: (I) flesh and fat; (2) kidnoy fat and membrano; (3) kidnoy; (4) flesh julco; (5) bonos.

- Their work showed that the bonos containod five to soven times as much minoral matter as tho softer parts. The percentage of mineral mattor in the goft parts is in all cases greater for the loan animal than for the fat animal. The percentages of mineral matter in the soft parts of the offal is genorally about the samo as that in the soft parts 
"3"

of the carcass. Consldering the entire animal the soft parts yleld mach less than 1 por cent of the live weight as mineral matter while the bones yleld from 3 to 4 por cont of the weight as mineral matter. As the animal fattens the per cont of mineral matter referred to entiro animal decreases in both bones and soft parts, which shows that 1ts increase is in a less proportion to the other constituents during the fattioning portod.

As to the fat the authors show that the amount of fat surrounding the kidneys Increases considerabily as the antmal fattons. In general the por cent of fat in the caroass Increases with age, other conditions bolng the same. A fat calf shows but 16.6 per cent of fat in the carcass, Wintle a modorately fat ox shows 34.8 por cent. In a mature, fattened boef animal it thus appears that about one-third of the live welght consists of fat. It also appears that three-fourths of this fat is found in the carcass. The oaul and intostinal fat forms tho greater portion of the fat associated with the offal. A much smaller portion of the fat surrounds the hoart whllo the remalning offal parts furnish but ilttle fat in comparison with those two just mentIoned.

As to nitrogen; there is four to five times as mich nitrogon in the soft parts of the carcass as in the bones. As the animal fattens, the percentage of nitrogen in the carcass decroases. The percontage of vater docreases also. It Is pointed out that the reason for this may be that the 


\section{$n$ 4n}

nitrogenous matertal of the body requires water to carry on Its functions properly. The fat calf shows about the highest percentage of nitrogen. Veal 1s considered loan meat and this is born out by these figures.

The authors have compared tho determinations of nitrogen obtained in three difforont ways. From the percentago of crudo dry substanse was subtracted tho por cent of minoral matter and fat found by analysis, tho rosult vas tho . por cent of nitrogenous matorial. Dividing by the factor 6.3 tho por cent of nitrogon thus found ras compared to the per cont of nitrogen found by a determination upon the composito omde dry substanco, and also to that found by adding togothor tho amounts of nitrogon found in oach soparato orudo dry substanoo. The results by these throo mothods comparo vory favorably with oach othor, although the rosults obtainod by diroot analysis aro all nighor than those obtalnod by calculation.

Again the colieoted offal parts contain a highor por oont of nitrogon than the collootod carcass parts. Howovor, about throo-fifths of the nitrogon is oontalisod in the orroass. Sinoo about one-fifth of this is in the oarcass bones, tho soft odible portion of tho carcass will contaln about ono-half of tho ontiro nitrogon of tho body. Sinoo some parts of tho offal aro odiblo, a part of tho twoflfths oxisting hero may not bo lost as food. Summarizing the rosults on wator, nitrogonous matorlal, fat and minoral 
matter, thore is soon a tendenoy of the por oont of nitrogenous compounds to rise and fall with the per cent of mineral matter. Th1s would seem to indloate some relation between the materlal furnishing tho minoral constituents and the nitrogen containing materlal in the body. The proportion of fat is generally greater than that of the nitrogenous compounds. In the caroass of the calf, however, they aro equal, in the half fat ox tho fat is one-fourth moro, in the fat ox thero is two and one-half times as much fat as nitrogenous substanco. In the carcass of good fat boof thore may be throe tines as much fat as nitrogonous substanco.

The authors have instituted Inquirios in an endoavor to learn what proportion of the fat and nttrogen of slaughtered antmals is actually consumed as food. This information comblned with their own observations, deductions and oaloulations of data, furnish the information of the following tablo oaloulated for tho entiro body.

\begin{tabular}{|c|c|c|c|}
\hline$\vdots$ & $\begin{array}{l}\text { Por oont Nitrogenous } \\
\text { Matorlal usod as food }\end{array}$ & $\begin{array}{l}\text { Por cont fat } \\
\text { usod as Food. }\end{array}$ & \\
\hline Oalvos & 60 & 95 & $\vdots$ \\
\hline : Oxen & 60 & 80 & : \\
\hline :Lambs & 50 & 95 & : \\
\hline Shoop & 50 & 75 & $\vdots$ \\
\hline P1gs & 78 & 90 & \\
\hline
\end{tabular}




\section{$n 6 "$}

They also assume that all the carcass fat and about one-fifth of the offal fat may be used as food.

To roturn to tho tables, the authors point out that wile the percentages of mineral and nitrogenous matter In the oaroass of the animal decreases during the fattening prooess, the percentage of fat 1ncreases. Th1s Incroase in the peroentage of fat is in greater proportion than the decrease of the other constituents, which means that the per cent of solids increases with fattoning. This is show by the percentage of water in the carcasses of the three animals analyzed: Calf, 62.25 por oent; Half lat 0x, 54 por cont; Fat 0x, 45.5 por oont. As meat is sold by the butcher the percentage of water would be $I$ to $z$ per cent less in each case due to $10 s$ by ovaporation:

The proportion of bone becomes less, the fatter the animal, but the porcentage of dry matter in the bone increased as the antmal matured.

Lawes and Glibert attempt to show the composition of the Increase in welght of a number of heifers and bullocks. These antmals, startod in the experiment under an average cond.tion of fatness, wore assumed to have the composition of the half fat ox which was analyzed. They were fod upon Pattoning food for a number of rooks and at the close of the exportmont were assumed to have the composition of the fat ox analyzod. 


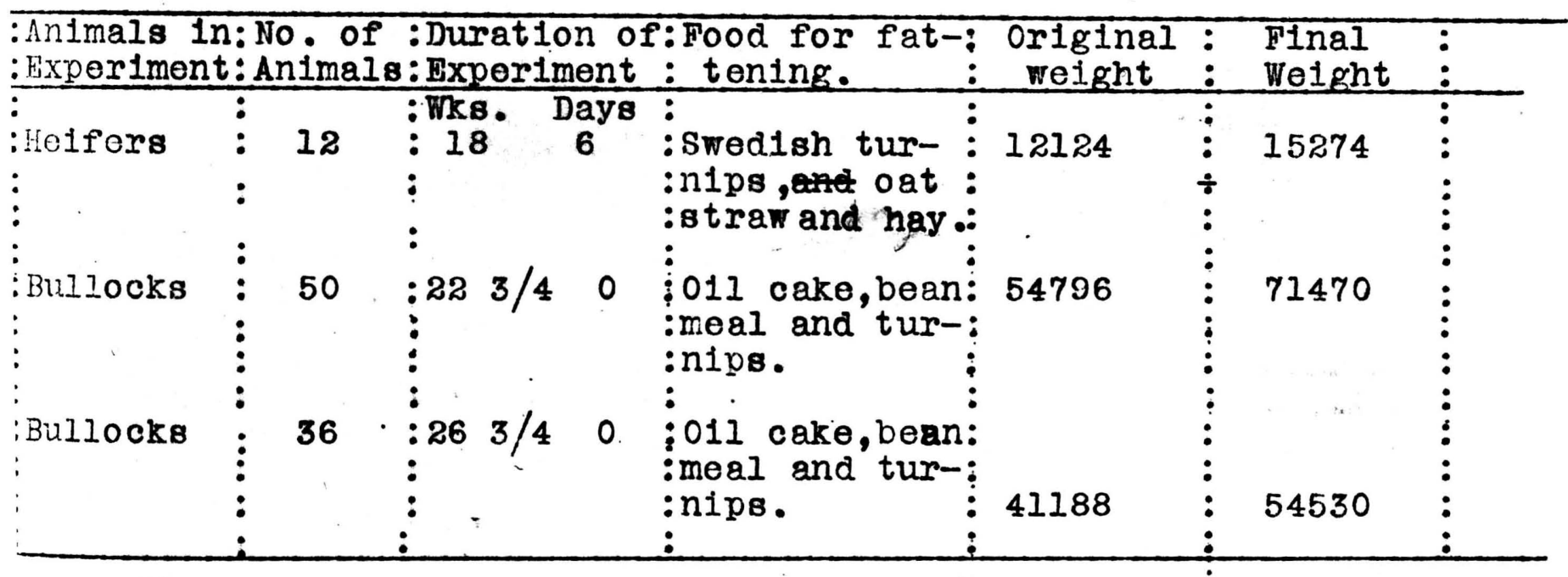

Calculated per cent in Increase.

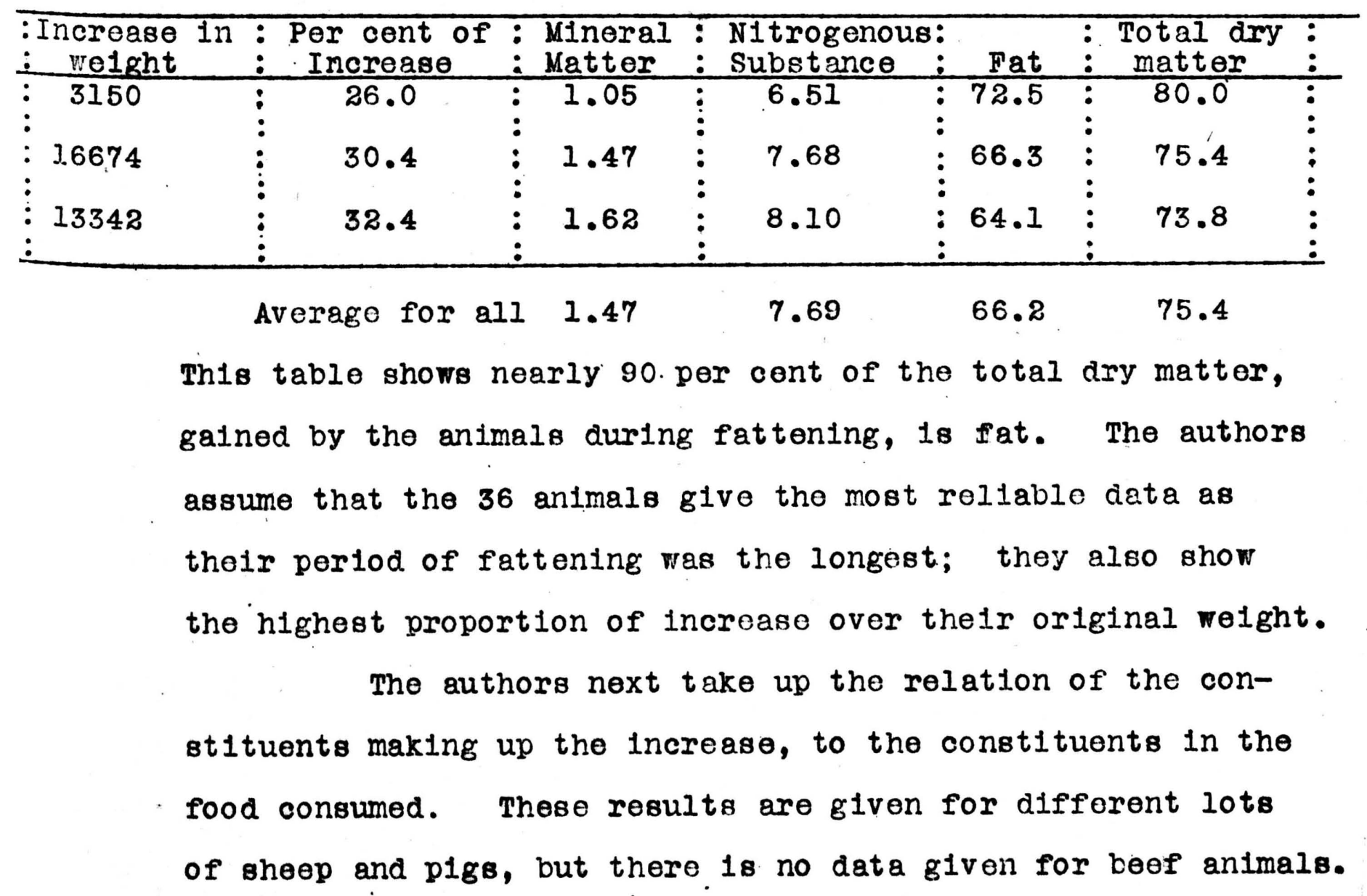


For sheep a general mean of all experiments gave the follow1ng:- 100 parts of dry matter in the food consumed gave 8.06 parts stored up in increase in the animal and 91.94 parts explred, perspired or volded. This quantity stored up in Increase was divided as follows. Mineral matter 0.21; n1trogenous compounds 0.72 ; non-nitrogenous matter (fat) 7.13; total 8.06 .

For p1gs 100 parts of dry matter in food gave 17.27 parts stored up in increase and 82.73 parts explred, perspired or volded. The increase was divided as follows:- Mineral matter 0.02; nitrogenous compounds 1.44; non-n1trogenous substance (fat) 15.81; total 17.27.

In all cases the amount and composition of the food consumed to produce the increase was determined by experiment, and the composition of the increase was calculated from that of the antmals analyzed.

As to the relation of the fat stored up in the increase to the ready formed fat in the food consumed, the authors point out that in the case of pigs, in whose food the ready formed fat was dotermined, an average of 400 to 500 parts of fat was stored up in the increase to 100 parts of fatty matter in the food consumed. Th1s plainly shows that a part of the fat stored up is synthesized or prepared from constltuents in the food other than the ready formed fat In the food. They hold that it may be produced from the nitrogenous constituents but are rather inclined to believe that the non-nitrogenous constituents, such as starch, constitute the main source of this formed fat. Discussing the relation of starch to fat ohemically they conclude that it 
would require 2.5 parts of starch to produce one part of fat, this relation being close to the minimum value. Taking the case of the single fat pig analyzed 13.2 parts of fat out of a total of 14.94 parts incroase were stored up for 100 parts of dry matter in the food. Of th1s, 3.26 parts could have been furnlshed by the food consumed. At least 9.94 parts must have been formed within the body from other constituents and consldering starch the material for this purpose 1t would require 9.94 times 2.5 equals 24.8 parts of staroh to provide this additional fat. Add to this the fat in the food, 3.26 , and the 1.73 parts of mineral and nitrogenous materlal fixed in the increase and we have 29.84 parts out of 100 parts of dry matter in the food contributing to 14.94 parts of dry 1ncrease. This would leave 70.16 parts explred, perspired or volded instead of 85.06 parts which $1 \mathrm{~s}$ found by taking the difference between 100 parts of dry matter In food and 14.94 parts stored in increase.

From this and other calculations it appears that 1t requires about two parts of dry matter of the food to produce one part of dry matter Increase, and that one-third of the dry matter of the food seems to be devoted directly to the formation of the increase. The remaining two-thirds of the dry matter of the food will contribute but little, if Indeed any, to the production of the 1ncrease. They probably furnish energy for the transformation golng on in the body Independent of Inorease of relght. 
As the the food of sheep and oxen there is about one-half as much dry increase produced from 100 parts of dry matter in the food as with p1gs. Also the proportion of fat increase is much smaller in the case of ruminents and their food is often richer in fat. It thus appears that a less proportion of the dry matter of the food would be used in the production of the fat in the increase.

Again considering the nitrogenous compounds we notice that 5 per cent or less of the nitrogen consumed is stored up as increase. The authors found that in the case of pigs a larger portion of the nitrogen consumed in the fattening food was excreted as urea. So that it may be possible or even probable that the nitrogeneous compounds may also vield the elements for the production of fat.

ACTUAL FRESH WEIGHTS OF ORGANS AND PARTS OF ANIMALS IN DIFFERENT CONDITIONS OF GROWTH AND FATNESS.

Lawes and GIIbert have given the above data for between 300 and 400 animals, in an effort to trace the tendenoy of relative development of the different parts as the animal grew and fattoned. On beef animals the actual fresh weights of the parts of two calves, two helfers and fourteon bullocks were obtalned. These 18 animals include the calf and two bullocks slaughtered for analysis.

The results show that the internal organs and offal parts in general increase in their actual welght as the animal fattens. Their proportion to the live weight of the animal, however, diminishes. Th1s is true expecially of the organs, 
which in general do not lay on fat during the fattening process. The internal fat increases both in actual weight and in percentage to the live welght of the animal. The carcass also Inoreases in weight and percentage during this period. COMPOSITION OF THE ASH OF CERTAIN SEPARATED PARTS AND OF THE ENTIRE ANIMALS SLAUGHTERTD FOR HUMAN FOOD. Th1s 1s supplementary to the first report of the authors and was published in June 1883. They report the results of the analysis of ash of the carcasses, the offal parts and the ash from the ent1re animals. The ashes were obtalned by burning the composited crude dry substance of the parts making up these divisions.

12 analyses were made upon ash of carcass,

$17 "$ " " ashes of offal parts,

$11 "$ " " " " entire animals.

For the ashes of the entire antmals the results are reported for crude ash and pure ash. The latter report 1s the same as the former excluding the sand and charcoal. Following 18 the report of the crude and pure ash of the threo animals figured upon their fasted live weight as 100. The contents of the stomach and Intestines are not Included in the parts analyzed.

\begin{tabular}{|c|c|c|c|c|c|c|c|}
\hline & \multicolumn{3}{|c|}{ Crude Ash. } & \multicolumn{4}{|c|}{ Pure Ash. } \\
\hline & Carcass & :Offal & Entire & :Carcass & Offal & Entire & $\bar{\vdots}$ \\
\hline Fat Calf & 2.782 & : & 3.800 & $\vdots 2.772$ & 1.006 & 3.779 & $\vdots$ \\
\hline Half Fat ox & 3.603 & $: 1.061$ & 4.664 & 3.568 & I. 044 & 4.612 & $\vdots$ \\
\hline Fat ox & 3.019 & $\vdots 0.901$ & 3.920 & $\vdots 2.997$ & 0.882 & 3.879 & $\vdots$ \\
\hline
\end{tabular}


The presence of carbonic acid in the ash is of interest in that it indicates more or less exactly the amount of base combined with organic acid. But the amount presont may be modifled by the conditions of incineration of the materlal, perhaps causing them to comblne with other constituents of the ash expoliting carbonic actd and forming more stable salts. The authors made some determinations of carbonlc acid upon some of their samples of ash after three difforent troatments. (1) After standing and not relgnited, (2) after relgnition, (3) after treatment with ammonium carbonate and heating to a low red heat.

Per Cent of Carbonic Acld.

\begin{tabular}{|c|c|c|}
\hline & $\begin{array}{l}\text { Average of five } \\
\text { : carcass ashes } \\
\end{array}$ & $\begin{array}{l}\text { Average of elght } \\
\text { entlire animal ashes }\end{array}$ \\
\hline $\begin{array}{l}\text { After standing not } \\
: \text { relgnltod }\end{array}$ & $\vdots \quad 2.59$ & 2.20 \\
\hline :After relgnition & 0.87 & 0.87 \\
\hline $\begin{array}{l}\text { Using }\left(\mathrm{NH}_{4}\right)_{\mathrm{CO}_{3}} \\
\text { and Ignit Ing }\end{array}$ & 1.52 & 1.48 \\
\hline
\end{tabular}

The authors havo adopted the results for carbonlc acid furnished by the last method, that 1s, using the ammontum carbonate. The ashes for the determination of the other constituents wore welghed out in the relgnition condition, whioh gives the. low result for carbonlc actd. Th1s accounts for the high totals of the complete ash analysis. The first constituent reported in the table, - Iron 
peroxide -, is much higher in the ashes of the offal parts than in the ashes of the carcass parts. In general it may be sald that the animal ash consists largely of phosphate of lime, that lime and magnesia are the charactertstic bases of bone ash, and that potash and soda are the characterlstic bases of blood and flesh. The bones furnish most of the phosphoric acid, some 1s contained in other parts also, and some may be formed from the phosphorlzed nitrogenous matter by oxtdation of the phosphorus in burning. The sulphurtc acld will be formed in part by the oxidation of sulphur in - burning.

The authors flgure that an excoss of base 18 found In ash of oxen and sheop, and a deficiency in the case of p1gs. The ash of the offal parts, which contain but little bone, run higher in potash and soda than does the ash of the carcass. Also the proportion of soda to potash is greater in the offal parts. These parts include the blood whose ash contains a high ratio of soda to potash.

The authors also have calculated the welght of ash ylelded by the different animals on the basis of 1000 pounds. It is thus seen that welght for welght, oxen carry off more mineral matter than elther sheep or pigs. The loss to the land in mineral constituents is not an important 1tem in the fattening antmals, although for growing animals the amount Is greater. Comparing animals to other farm products, it may be sald in a genoral way that an acre of land rould lose more phosphortc actd in milk, and four or flve times as much 
phosphorlc acid in wheat, weight for weight, as it would lose in the fattening of oxen or sheop. Of lime the acre of land would lose trice as much in animal increase as in mllk or wheat, but only one-tenth as much as in hay. of potash a small fraction of a pound would be carried off by the animal, six times as much milk, twenty times as much by wheat and one-hundred times as much by hay.

other work along this line of neat investigation has been done and some mention should be made of these. In 1894 Dr. Paul Schwoitzer of the hissouri Agricultural Fixporiment station published the results of his rork with ten boof animals giving the fresh weights and the analytical data of the parts of the offal and the carcass. The carcass was divided into wholesale cuts according to the old Fnglish system which varies to some extent with the systom used today at the American Packing House. Instead of proparing the sample fiom the entire organ or part, a slice was cut out from the center of the same and having assumed that this sice represonted a fair sample of the whole, it was usod to obtain the material welghed out for analysis. In drying the fresh matcrial for analysis the fat would melt out from the fatty portion. To obviate this difficulty the visible fat was carefuliy trimmed off, welghed, and assuming same to be pure fat it was arded to the fat obtalned by analysis of the dried sample and the per cents of the constituents recalculated to obtain the percentage composition of the frosh material. 
Because of the above variations in the analytical procedure It seems useless to compare this data with that of other investigators, as no conclusions could be properly drawn therefrom.

A. R. Vinson (Beltraege zur Methodik der Analyse ganzer Tlerkoerper, Univ. of Goettingen, 1904) has reviewed the work of Lawes and Gllbert, Henneberg, soxhlet and the German Agricultural soclety. Much of the data of Lawes and Gilbert reported in pounds and ounces has been changed over to the metric system. Henneberg (Jour. fthr Landw. 1878 p. 549 ) reports slaughter house welghts, welghts of food const1tuents consumed and growth. In flesh and fat of a number of shoep.

The work of Soxhlet (Versuch ther Fettbildung Im Tlerkörpen; Zeit. des Landw. Vereins Im Bayern Aug. 1881), gives the result with three pigs, one belng killed as a cheok animal and the other two after having been fattened 75 and 82 days respectively. A report is made of the live welght, empty welght, dry matter, molsture, fat, fat free dry matter, albumen, nitrogen and ash of the three animals, and the increase of each constituent in the last two plgs during growth, using the check antmal as a basis. Martiny reports the work published by the Gorman Agrlcultural soclety (Heft 18). This is a roport upon the prinolpal slaughtoring houso wolghts for thirty head of boef cattle of three breeds. The average, the highest and the lowest welghts are reported for each breed. 
Vinson himself undortook some slaughtoring exporiments with pigs. The object of his investigation was to determine how much flesh can be used as food from the carcass and the offal. He obtalined the live weight at the stall and just before ktlling. In planning the slaughtering house work, he divide the data of weight there obtalned into stx divisions.

1. offal - cannot be used as food for man.

2. Offal - used as food by man.

3. Offal - fat used as food by man.

4. Contents of stomach, intestines and bladder (urine).

5. Carcass: Including head, tall, feet, ears, kidney and kidney fat. Carcass split and each half wotghed separately.

6. Loss including bristlos.

After cooling the carcass down, it was rolghed and divlded into tho following parts. Head (with oars) foot and tail, kidnoy fat, kldney, knuckles, hams, shoulder, belly, sldes, back, "carbonade", chuck and ribs. Each part was welghed and further divided into flesh and fat, bone and skin. The followlng were taken for the analytical work. (1) Kldney fat, (2) belly fat without skin, (3) back fat without skin, (4) flesh and fat from other parts including kldney but not including skin, head, feot and tall, (5) flosh and skin of hoad, feot and tail which could be romoved by hand, and the skin of knuckles, (6) skin of other carcass 
parts not in (5), (7) composite bones.

These wore ground in a mill or chopper in preparation for weighing out the sample. Duplicates of about 300 grams were welghed out into beakers and dried at $100^{\circ} \mathrm{C}$. The fat which melted out was poured through a funnel stopperod with a plug of cotton, the fat beling recoived into a tarod flask. When most of the molsture was gone, the mass was treated with ether, and the solution poured through the same filter into a second tarod flask. This was repeated several times and the residue was then dried again troated with ethor and pourod off as beforo into a thlrd tared flask. After distilling off tho ether and drying, the three portions woro welghod and mixed. This fat was studiod for its lodine value, refractive tindex and average moledular weight and melting point. These last determinations wore made upon the kidney fat, back fat, belly fat and intestinal fat only. The molsture and fat free residue was allowed to come to an air dry condition, then ground fine. Upon this were made determinations of molsture, fat, ash and nitrogen, and from these, results wore calculated to the fresh matorial. Vinson describes at some length his studies in the comparison of analytical methods for meats, and also roports the results of his work upon the different fats of the pig. The fat of pigs fed a normal ration is compared with the fat of plgs fed (1) sugar, (2) tankage, and (3) 
peanut 011. He reports the welghts of the following parts for the four different kinds of fed pigs. Heart fat, intestinal fat, kldney fat, back fat, belly fat, flesh, bones and skin. The lodine value and refractive index were determined upon each of these fats for the four different kinds of foeding, and the average molecular welght, saponifacation value and delting point upon the fatty aclds obtalined from each fat, for the different kinds of feeding. The most interesting varlations shown are the differences between fat Instde the animal:- heart fat, kidney fat, intestinal fat:and fat on the outside:- belly. fat, back fat - etc. The Inside fat uniformly shows a higher melting point and a lower lodine value than do the outside fats. The fats from the ples fed upon peanut oll show without exception a higher lodine value and a lower melting point than do the fats obtained from the other methods of foeding. In general the lodtne value for the different fats is lowest for the normal or sugar feeding.

The rosults for refradtive indices, molecular weights and saponffacation values show little or no definfte varlation with one another.

VInson also studied the Influence of these ddfferent kinds of feeding upon the composition of the heart and hoart fat. The heart fat from the protein (tankage) fod plg was distinctly different, physlcally, from the others. on analysis it shows the highest per cent of rater. In regard to the fat the heart from the sugar fed pig contains the 
"19"

highest per cent of fat; the largest anount of heart fat also was obtained from this same pig. From the tankage fed pig we obtain a large amount of heart fat, which, however, differs from the normal hoart fat in 1 ts high molsture and low fat content. The corresponding heart shows little difference from the heart of the normal fed animal.

A remarkable fact is the large welght of the heart of the pig fed upon peanut o1l, this animal also gave the highest wolght of flesh. It would be difficult to say definitely whether this was due to individuality or strictly to the foed, in view of the fact that we have but one experiment furnishing the data. It is highly probable that a carbohydrate ration favors the addition of fat, both within and about the heart, which ration rich in fat does not appear to do.

Bulletin No. 53 Division of Chemistry, United States Department of Agriculture published in 1898 by Dr. W1ley deals with the Chemical Composition of the Carcasses of PIgs of different breed. Ten representative animals of each of the following slx breods; Poland China, Berksh1re, Duroc Jersey, Chester White, Tamworth, Yorkshire were ralsed under a standard controlled diet to about 200 pounds welght, by the Iowa Fxperiment station. They were slaughtered at Swift's Chicago Packing House, the welghts of the carcasses and soparated parta being taken at this timo, with the excoption of the hal and blood. Three representat1ve carcasses of the Duroc Jorsoy and one obch of one of the other breeds, were selected for 
analysis. Before leaving Chlcago, each carcass was divided, and the following cuts welghed and sent to Wasmington for analysls. Two American clear backs; two cloar bollies; two short cut hams; two Now York shoulders; four foet; spare ribs; tenderlolns; neck bones; back bones; lean and Iat trimmingș; tall. On arriving in Washington these were again welghed and divided into the following:- Meat (lean and fat), bones, marrow, skin, spinal cord, tendons, hoofs, After wolghing these parts thoy were used for the analysis proper.

To briefly sumarlzo this investigation, the data shows the following points. (1) The Tamworth shows the highest percentage of bones and hence the heaviost skeleton. The Duroc Jersey shows the lowest per cent of bones, ( 2 )the Berkshlre shows the hlghest per cont of water, 43.1 ,per cent and the Duroc Jersey the lowest, 30.3 per cent, (3) the Duroc Jersey shows the highost per cent of fat, 57.68 per cont, and the Berkshire the lowest 40.46 , (4) the Berkshire shows the highest por cont of nitrogenous substance, 13.02 per cont, while the Duroc Jersey shows the lowest 8.96 per cent.

Emmett and Grindloy (Jour. of Ind. \& Eng. Chem. July 1907 ) have reported analyses of beef kept in cold storage and in the frosh condition. Two beef steors were slaughtered, the carcasses divided into two halves as usual and placed In cold storage. The round, rib, plate and loin were taken 
for analysis from ono-half of the carcass of one animal after two days, and the same cuts from the other half after 22 days further intorval. From the other animal, tho chuck and loln were taken for analysis from storage from one-half of the carcass after six days, and the same cuts from the other half of the animal after 37 days longor in storage. The lean beef from these cuts after thorough grindIng and careful sampling were submitted to a more or 1 ess complete analysis. The following results are roported. Water; soluble and insoluble dry substance; coagulable and non-coagulable soluble protein; Insoluble proteln; nitrogenous and non-nitrogenous organto extractives; soluble and insoluble ash; nitrogen as coagulable and non-coagulable soluble protein, as non protein soluble substance, as 1:1soluble substanco; rat1o of protein to non-protein substanco in meats and their oxtraots; inorganic and organio soluble phosphorus; Insolublo phosphorus.

The conolusions dram by the authors from this work are (1) no 10ss of molsture from the meat after the 22 days storago and a small. $108 \mathrm{~s} 1.3$ por cont after 37 days. (2) No apparent change in the forms of ash, protein, and sol1ds and only a small change in the soluble phosphorus and nonnitrogenous extractives after 22 days and (3) that the nutritIve value was unaltored. (4) Aftor 37 days the ohango of the forms of solids, proteln, phosphorus and extractives was notlooable but as far as nutritive value was concernod had not lost any appreolable amount, but had rather gained than other- 
wise due to an increase in soluble protein and extractives. Grindley and his colliaborators have published a sertes of elght or more papers on the chemistry of flesh (Jour. Amer. Chem. Soc. 1904 to date), but thetr work does not bear directly along our line.

At the present time investigations are in progress at the Vermont Experiment station on the composition of young. pork fed upon milk, varytng from sktm milk to whole milk. The rosults of this work have not yet been published. Wildt, (Landwirt. Verskcstat. 15 ( 1872 ) 404) rorkIng with rabbits, constdered the composition of kones with spocial reforence to the age of the antmal. He shows that the composition of the skeleton varies very markedly in rabbits of different ages. The fat increases and at the anme time the water content decreases. In per cent of the rreah, the nosseln" remains nearly constant for varying ages, but reckoned upon the molsture and fat free basis, the proportion of "ossein" is smaller, with age. According to Wildt the "pure" or fat and water froe bono contains in addition to the "osseln" only calclum and magneslum phosphate, calclum carbonate and calctum fluorlde. He found the ratio of organ1c to inorganlc matter in the skeleton decreased very greatly with ago. He gives as a result of his investigations that the composition of the skeleton of full grown animals Is dependent only upon the degree of fatness of the animal, and that the age has littlo effect, after full growth is reached. 
Diiring (ze1ts. Phys. Chem. 7, 1882, 446) working Wh the bohes of fowls gives the following composition for breast, humerus, and fomur of the hen and goose (our average): dry substance, 93.26; ash, 57.85 per cent.

C. Sedimalr (Ze1ts. f. B101. 37, 1898, 25 ) studied the effect of hunger upon the skeleton of cats, and reached the following conclusions. The bones contained in most cases a higher percentage of water and a lower percentrge of fat after a perlod of hunger. The dry substance decreased both absolutely and proportlonately, the hollow bones of the extremities losing more in welght than the rest of the skeleton. The loss of dry matter in the skeleton was largely fat, but at the same time there is an actual loss of every const1tuent, the Inorgan1c as well as the organtc part. Longer duration of the perlod of hunger increased the $10 \mathrm{ss}$ in the skeleton.

The effect of lack of nourlshment upon the skeleton of rabblts was investigated by H. Gusmitta, (Abst. In Jahrs. Ber. Tler. Chem, 24, 188s, 401). He concluded that during starvation; (1) the total welght of the skeleton docroases; (2) the fat content decregses very markedry; (3) the total amount of organlc matter, other than fat, remalns nearly constant; (4) the proportion of calclum phosphate to ossein romalns practically the samo.

The effect of starvation upon the skeleton of rabbits was also investigated by H. Wolske, (Ze1ts. Physiol. 
Chom. 221895,595$)$. In this rork he used four animals of the same ago. One was killed as a check, the others confined without food. At the ond of seven days another was killed. The remaining animals died. In ton to eleven days respectively. HIs results show that the skeleton lost less in proportion than any other part of the body. The greater part of the loss in welght of the skeleton was as fat. The table quoted here gives the rosults of Welske's experiment in condonsed form.

\begin{tabular}{|c|c|c|c|c|}
\hline $\begin{array}{l}\text { \% skoloton in } \\
\text { whole body. }\end{array}$ & $\begin{array}{c}I \\
\text { Chock } \\
\text { Antmel } \\
\% \\
32.46\end{array}$ & $\begin{array}{l}\text { II. } \\
\text { Kiliod } \\
\text { after } 7 \text { das. } \\
41.7\end{array}$ & $\begin{array}{c}\text { III } \\
\text { D1ed In } \\
10 \text { das. } \\
\phi_{0.7} \\
41.7\end{array}$ & $\begin{array}{l}\text { IV. } \\
\text { Died in } \\
11 \text { d88. } \\
\text { \% } \\
39.9\end{array}$ \\
\hline $\begin{array}{l}\text { Loss in wolght } \\
\text { of skeloton }\end{array}$ & $-\infty-$ & 4.1 & 3.3 & . \\
\hline Fat in skeleton & 13.04 & 0.54 & 0.79 & 0.52 \\
\hline Ash in bones* & 61.94 & 60.27 & 62.26 & 60.56 \\
\hline $2^{0_{5}}$ in Dones & 24.17 & 24.02 & 24.67 & 24.22 \\
\hline
\end{tabular}

Wheokoned on the $\mathrm{H}_{2} \mathrm{O}$ and fat freo bas1s

P. F. Trowbrldge and F. W. Woodman (Jour. Ind. and Eng: Chem. Vol. 1, No. 10... 0ot., 1910.) give as the conolusions of their work with five steors the following:

(1) Young, growing stoers continue to grow in helght and bulld up skeletion evon when losing welght.

(2) The skeleton is uneffected by poor nutrition unt1I practically all of the fat has boen removed from the muscles and other organs.

(3) The prinolpal offoct of poor nutrition upon the skeleton 1 s the removal of the fat or arrow and the replace- 
ment of this with wator.

(4) The per cont of organic matter other than fat is practloally constant for the wholo skeleton, under different conditions of nourishment.

(5) No evidenoe was obtained to rarraint the conclusion that the mineral matter is resorbed, or afrected in amount, due to lack of proper nourlshment, although in one steer thero is some indication that this may have taken place.

(6) The proportion of fat and molsturo in the correspondIng parts of the skoleton is falrly constant for normally fod stoors. In stoors which have suffored from insuffictent nutrition for a long perlod the fat may be nearly all resorbed from the skeleton, and this rosorbtion takes placo from all parts of the skeleton.

(7) The proportion of organic and intneral matter in the skeleton varios with age. This proportion varios in the different parts of the skeleton, according to the nature of the bone.

(8) The per cent of phosphorus in the ash of the skeloton of steors is noarly constant. The por cont of phosphorus in the ash of different parts of the same steer varles, but the average for the corresponding outs of the flve steers Is falrly constant, showing a varlation of not more than 0.7 per oent.

The results of malnutrition upon the water and fat content of the body of animals has been potinted out by carl 
Voit (Hermann's Handb. d. Physiol. 6, 1881, 1-575). He assorts that in the case of bad nourtshment the whole body becomes watery; a woll nourlshed organism, un the contrary, contains more dry substanco, since in it thore is more fatty tissue with less water content.

I. Pfolffer (Zeits. f. Blologie 23, 1886, 340) working on dogs, rabits and chlckens cane to similar conclusions. S. Hatal (Amer. Jour. Physiol. 18, 1907, 309) working with rats showod that partial starvation gave a high percentage of water in the fatty tissue.

C.R.Moulton and P. orrowbride Ina paper on the composition of the fat of beef animals (Jour. of Ind. and Eng. Chom. Vol. 1, No. 11, p. 761) have shown that the percontare of fat in the fatty t1sauo of stoors 1ncroases with the fatness of tho animal while the molsture decreases.

C. K. Franols and P. F. Trombridge (Jour. of B1ol. Chom., VII, No. 1, p. 8I) in their article on phosphorus in boof animals give tho following results: 1 , the offal systerns contatu the highost percontagos, of phosphorus (not Including the bones) of all parts of the animal, the order being - nervous system, liver, resplratory system, digestIve system and excrotory system, and circulatory system; 2 , the fat carcass cuts, or in the thin animals the cuts containing the most connective tissue, are lowest in phosphorus; the cuts high in lean meat are high in phosphorus; 
" 27"

\section{EXPERIMENTAL PART.}

\section{DESCRIPTION OF ANIMALS.}

Provious Treatment.

The steers used in the experiment, numbers 18, 121, and 48, belonged to the group known, at the Agricultural Exporiment station of the Untversity of Missour1, as Regular Maintenance Cattle. Provious to May, 190\%, they had been used in a cooperative feeding experiment. They were discarded from that experiment on account of their poor showing. They were good representatives of a poor feeding type of animal. They were turned to pasture unt11 November, 1906 , When they were put on a ration of alfalfa hay and kept on $1 t$ until the beginning of this experiment, February 1, 1907. At this time they were coarse steers in a very thin condition. Quartors and General Troatment.

At the beginning of the experiment, these steers were kept at night in the Dalry Barn, and during the day were given the run of a small lot. In the barn they were tied in stalls, each of the stalls being three feet and elght inches wlde and floored with plank. Sawdust was used as bodding. The lot in which they were turnod during the day was long and narrow and contalned about 1000 square feet. During wet weather of spring this lot became very muddy several times 


$$
" 2 \sigma^{4}(2) "
$$

3 , on a molsture and fat free condition those cuts (lean) which are highost in connective tissue are lowest in anount of phosphorus; 4, there seoms to bo no relation between ash and phosphorus content. 
and It was found necessary to move the cattle to another lot, which contained three-fourths of an acre.

on July 11, 1907, the steers were moved to the new shed bullt for this experiment. This shed faces south and has an open front. The stalls are each three feed eight inches wide and floored with plank. Sawdust was st1ll used as bedding. The steers wore tied in the stalls at night and-given the run, during the day, of a lot containing 1400 aquare feet and provided with a hydrant and water trough. Each steer had a neck strap with a brass tag giving his number.

The steers were fod hay and grain at night and grain in the morning. After eating the morning feed, they wore welghed and turned into the lot. They were fed at the same hour each night and morning and were weighed at the same hour each morning.

\section{Broed and Age.}

No. 48 was a grado Shorthorn classed as a sentor yoarling in Decomber, 1905. Calved in the spring of 1904, he was therefore almost throe years old at the beginning of this experiment. He wa nearly five yoars old when slaughtored.

No. 121 was a grado Shorthorn. In November, 1905 he had been purohased as a calf. He was thus a scant two yoars old at the beginning of this experiment. He.was between 
" $29 n$

two and a half and three years old when slaughtered.

No. 18 was a grade Shorthorn purchased at the same time as No. 121 and of the me age. He was nearly three. years old when slaughtered.

\section{Method of Feeding.}

The grain fed these steers was composed of corn chop (cracked corn) and linseed meal in the proportion of elght parts corn to one part linseod. The hay was alfalfa hay. On February 1,1907 , the steers were put on maintenance, 1.e. they wore fed sufflolent food to maintain their body wolght but not to allow any gain. The daily ration per thousand pounds varled around seven and a half pounds of grain and four-tenths as much hay. The quantity of foed was increased or lessoned as was necessary to keep the body weight constant. Water and salt were given ad libitum.

No. 18. This steer weighed 763.6 pounds at the first of February, 1907. From then unt1l November 12, 1907 he was kept on maintenance. H1s average welght for the last ten days of the maintenance period was 778.1 pounds. On November 12, 1907, he was slaughtered for analysis. No. 121. Th1s steer welghed 763.5 pounds at the beginning of February 1907. From then until July 10, 1907, . he was kept on maintenance. H1s average weight for the last ten days of the maintenance period was 764.8 pounds. on July 11, the feed was ralsed in quantity gradually until the 
steer was consuming all he would eat. This was continued unt11 Decomber 10, 1907, when the steer welghed 1261.3 pounds. This made a gain in five months of 497.1 pounds. On Decombor 11, 1907, this steor was slaughtered for analysis. No. 48. Th1s steer wetghed 840 pounds at the first of Fobruary 1907. From then until June 30, 1907 he mas kept on malntenance. H1s average weight for the last ten days of the maintenance perlod was 841.5 pounds. At this time he was gradually put on full feed until he was consuming all he would eat. In the middle of November, 1907 , this steer showed lack of appetite and had a bad cough. Th1s steer caught cold in the digestion stalls. He was blanketed for several nights. His cough still continued into December. On December 19 the tuberculine test was tried. The stecr showed a high temperature but gave no reaction for tuberculosis. From then unt1l January 15, 1908, he was fed all the hay he could eat, no attempt belng made to keep the proportion of hay to grain at tho theoretical figuro. In May the steor was again'off feed'and out of condition. Towards the latter part of the summer he ploked up and his appetite returned. Th1s animal was kept on full feed until January 18, 1909, when he welghed 1785 pounds, a gain of 943.5 pounds in 17.5 months. On January 18, 1909, this steer was slaughtered for analysis.

Digestion Trtal. From October 29, 1907, noon unt11 November 8,1907 , noon, steors 48 and 18 were in a digestion 
experiment in the digestion stalls. The results of the trial will not be discussed in this thesis.

Welght and Feed Records.

Dally records of the weights of the animals and of the wolghts of feed fed and feed refused were kept throughout the experiment. Representative amples of the corn, IInseed, and alfalfa hay were taken for each lot of feed and wore analyzed for the usual constituents by the offlcial methods. Samples were also taken of the refused hay and refused grain. These wero analyzed as barow.

No1sture, ash, crude proteln, orude fat, crude flbre, and nitrogen freo extract were determined by the offlotal Methods of the A. O. A. C. (U. S. Dopartment of Agriculture, Bureau of Chemletry. Bulletin No. 107, rev1sed pp. 38 - 56). Records and Methods of slaughtering,

on the morning the animal was to be slaughtered it was fed and weighed as usual but no water was given. The animal was taken for slaughtering to the slaughter house. Th1s 1s a two story frame bullding otwated botween-thomatry

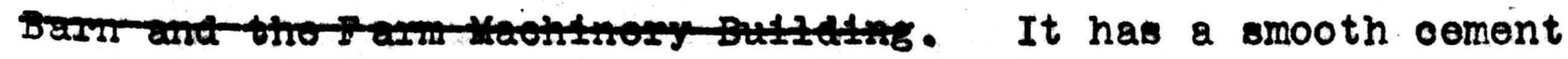
floor, 1s suppliod with a drain, steam, water, eloctric ourrent for lighting and power, stoves for heating, a windlaes and pulley with a strong rope for holsting the animal, an overhead track for hangling the oarcasses, and a falrly complete set of slaughtering and butohering tools. The steor 
was killed with a killing hammer, then strung up by the heels and bled as completely as possible. The blood was caught In a tared pan and welghed and its volume determined. Samples were taken in triplicate for analysis before the blood clotted, All blood whlch oozed from the earcass on to the floor during tho aressing of the carcass, was colloctod and

The carcass was lowered and the regular slaughter house separations made as practlced by the Kansas olty paokers. Welghts were taken of all the parts and organs as soon as they were separated by the butcher. These Included: the feet; the dew olaws; the hide; the head; teeth; horns; tongue total; tongue marketable; tongue bones; tongue base; gullet; lungs and windplpe; heart, porlcardium and adherent arter1es; heart marketable; heart lean; caul fat (the apron covering the intestines and stomach); diaphragm (skirt), stomach and contents, àdherent organs and fat; stomach cleaned; intestines and contents, adhorent organs and fat; intestines cleaned; stomach fat; Intestinal fat; spleon; pancreas; liver; gall bladder and gall; penls; bladdoriand contents; bladder; tall; brains; and splnal cord. The stomach was oloaned by washing in water. The intestines were cleaned by stripping and washing. The longth of the intestines was measured. All adherent fat had been separatod as cloanly as possible provious to the washing.

\section{Offel Parts.}


future work. Analysos wore made of the foliowing:

1 hido and halr;

2 circulatory systom, including heart, pericarcium, adhorent fat and large arteries;

3 resplratory oystem, 1nicluding lungs and trachea;

4 nervous system, including brain and spinal cord;

5 digestive and excretory system, Including clean stomach, clean Intestines, spleen, pancreas, gall bladder and gall, ponts and bladdor (ompty). tongue baso, gullet, dlaphragm; $1 \therefore ; ;$

6 11ver;

7 the offal fat, including caul fat, stomach and intestinal fat;

8 and the kidneys.

Carcass. As the weather was generally cold enough to chlll the carcasses in the slaughter house, thoy were hung for two days to chill out and sot. Tho carcass was thon wolghed in whole or in parts and it was cut up into wholesale outs as is the practioe of the Kansas C1ty packers. The following are the outs: ohin, chuok, nook, rib, plate, flank, loln, round, mump, shank, and the kldney and the kidney fat. The wolghts of these were reoorded and each out was thon soparated Into loan, fat and bono, making as cloan a soparation as was possible by hand, using a boning knifo. The parts woro wolghod. The hoad and the tail from the offal parts wore separated in the same manner. The total skeloton of the animal was composited and analyzed as one sample. 
The kldneys wére analyzed as a soparate samplo, both kldneys being taken. The kldney fat was treated as a separate sample. In all cases the right half of the animal was taken for this work, the loft half being used for photographs, water color drawings and cooperative cooking experiments. The following samples wero analyzed:

1 shin, shank, head and tall, loan and fat;

2 round and rump, lean and fat;

3 loin, loan and fat;

4 flank and plate, lean and fat;

$5 \mathrm{rib}, \mathrm{loan}$ and fat;

6 chuck and neck, loan and fat.

The above classification of samples holds in its entirlty for steor No. 18 alone.

The following additional samples wero analyzed for Steor No. 121. The loan heart was analyzed soparately from the elrculatory system. The markotable tongue was analyzed soparately as was the stomach. The round and rump lean formod one smplo and the round and mup fat another; the loin lean one samplo and the loin fat another. The Ilb loan was alayzod soparately from the rib fat.

W1th steer No. 48 the heart marketable was analyzed separately from the clrculatory systom. The stomach and marketable tongue formed samples soparate from the digestive and excretory system. The lean and fat of the rump formed one sample, the round loan anothor and the round fat another. 
" 35 "

The loin lean, loin fat, $\mathrm{rlb}$ lean and rib fat fomed four soparate samples. The skeleton with this animal was divided into samples as follows: feot, head and tail; shin and shank; round; rump; loin; chuck and neck; flank and plate; rib:

When plans were first made for this work with the Regular Maintenance steers it was thought that tho analyses of total systems or total animal were all that were wanted. It was later decided to increase the number of samples as this would mako posstble some comparisons which wero then deemed valuable.

Preparation of Samples.

As soon as the skeleton samples could be got roady they were ground through a Mann bone grinder, mixed well and a sample taken and sent to the chemical laboratory. The lean and fat and offal samples were ground through a power grinder with plates with holes of four difforent stzes. Samples were ground through the coarser plate and next the socond plate. The samples were then well mixed and quartered down, if nocessary, and then ground through a finer plate. The large samples were then quartered down again and ground through the finest plate. Very homogeneous and fine samples were easily obtained in this manner. An especially difficult sample to get uniform and ropresentative was the respiratory system. The cartilagenous rings of the trachea would partly romain behind in the grinder whtle the softer lungs were squeezed out past them. But by using a knife and patience 
these could be cut fine and mixed with the lungs. The aocompanying table jives the triplicate anglysos of throo samjes erom exch of the steors. These samples are among those harcest to rake uniform.

\section{COMPARISION OF TRIPLICATE DET FRMINATIONS.}

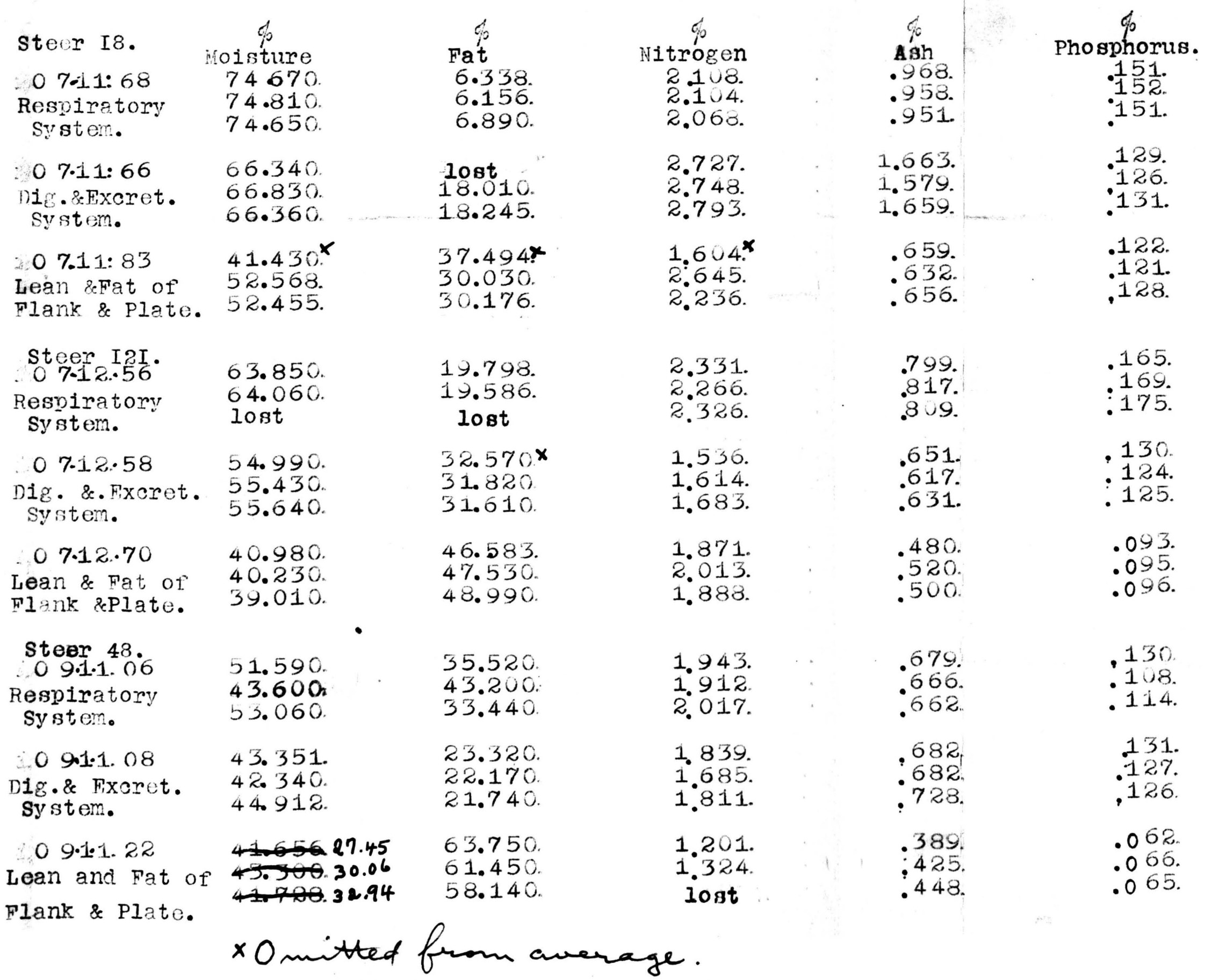


$" 36 a "$

\section{Mothod of Analyg1s.}

Moloture $\left(\mathrm{H}_{2} \mathrm{O}\right)$. For thls work tho S. and S. extraotion sholls and glass tubos with hardenod fllter papor bottoms woro fliled about ono-third full of Ignitod sea sand and then stuffed with fat free absorbent cotton. In our later work, cotton alone was used. The tubes were numbered consocutively, extracted with ether, dried in vacuo and welghed in glass stoppered wolghing bottles: This was done previous to slaughtering. A counterpolsed weighing bottle was found very convenient as it obviated complications arising from a broken welghing bottle, the use of a new bottle and subsoquent corrections of welghts. Scheibler vacuum desiccators six Inches in diameter with stop cocks in the lid were filled to the depth of an inch with C.P. sulphurle acid (sp. gr. 1.84). A brass gauze or porcelain plate was placed on the shelf of the desiccator and a half inch above this supported by corks or rubber stoppers was a second gauze: Clean paper was placed on this. It was necessary to have the ground glass surfaces and stop cocks fit well. A lubricant of three parts of hard paraffine and five parts of yellow vasoline was propared by melting together these ingredlents and allowing the mixture to cool slowly. In cold weathor a littlo more vasolino is used and in hot weather a little more paraffine to give the mixture the proper consist- 
ency.

The thoroughly mixed samples were placed in welghing bottles provided with short aluminum scoops and triplicate samplos of three to five grams wore wolghod out. The cotton was removed from the extraction tube and placed in a flat bottomed, shallow glazed porcelain dish and the sand was pourd carefully into the dish. The moat sample was placed on the sand and the whole was carefully and thoroughly inixed and thein returned to the tube by a steol spatula. Tho cotton was ueod to wipe every trace of the sample from the dish and spatula. A largo shoot of glazed papor prevented loss of sand. The last of the unused cotton was placed in the top of the tube. Later whon cotton alono was used, the mixing of the sample was greatly facilitated and the danger of 1088 of sand was entirely romoved. The sand or cotton, was used to soparate the particles of the sample and so allow a more thorough drying and extraotion. Otherwise the samples had to bo ground and reoxtracted a socond time. The triplicate samplos woro placod in soparato desiccators in ordor to a vold a Ioss in oaso a dosiccator was broken or acid spliled on the cones. The desiccators held fiftoen to twonty tubes. The dosiccators whon full woro exhaustod to a one millimetor vacuum by means of a Geryk duplex vacuum pump. The desiccators were rotated carefully twitco a day to $\mathrm{mlx}$ the concontrated acld with the supernatant watery layor. Aftor twonty-four to forty-elght hours or longer, as convonient, air was allowed 
to bubble slowly through a sulphurlc acld towor into the desiccator until the vacuum was destroyed. The tubes were transferrod to desiccators holding fresh acid and the drying was continued as before. The tubes were then transferred to glass stoppered woighing bottles and weighed in the welghing bottlo. The drying was continued to constant welght as given in detail above. Loss in weight is moisture. Fat. The dry tubes from the moisture determinations wore extracted for twenty-four hours in sohxlet extractors, using ether. They wero partially driod in an electric oven at a low temporature and then dried in the vacuum desiccators as given in detail above. They wore welghed as above and dried again to constant weight. Loss in weight is fat. Nitrogen. Nitrogen was determined by the modified Kjoldahl-Gunnlng mothod. Triplicate samples were wolghed out as in the fat determination and placed in $\mathrm{S}$. and $\mathrm{S}$. No. 595 fllter papers and introduced Into a 500 c. c. Kjeldahl flask. For hide and halr 0.50 to 0.75 grams was used, for lean moat 1.00 to 1.25 grams, and for fat samples 2.50 to 3.50 grams. Other samples in accordance to the nitrogen content. Twenty-five cubtc contimeters of C.P. concentrated sulphuric acld was used for the meats and 35 to $50 \mathrm{c.c}$. for fats. About 0.7 grams of morcury was added and the digestion was made on a digestion frame. When the sample had ceased foamIng and was not pasty, 7 to 10 grams of $\left(\mathrm{K}_{2} \mathrm{SO}_{4}\right)$ potassium sulphate was added and the digestion was continued for one or two hours. The flasks wore then cooled and the nocks 
" 39 "

washed down with water. They were again digested for an hour or more. About 300 c.c. of nitrogen free water was added to the cool flasks also a plece of paraffine the size of a pea and a fow small pleces of granulated zinc. Then 85 c.c. of the alkali solution ( 100 c.c. for fats) was added carefully, the flask was connected with a condensor, the contents were mlxed, the flasks bolled for forty minutes and the distillate caught in a wido mouth roceiving flask containing the necessary amount of one-tenth normal hydrochloric acid with some cochineal indicator. The above alkali solution was made by dissolving forty pounds of Greonbank alkali and 375 grams of potassium sulphide in thirty litres of iistilled water. For fats and other foaming matorials 800 c.c. Kjeldahl flasks were used.

Proteln. The protein was calculated by multiplying the nitrogen by the factor 6.25 .

Ash. Triplicate samples of ten to fifteen grams wore welghod out as for fat and placed in numbered, tared porcelain crucibles. The samples were dried in ovens and then charred carofully. Lator they were ashed over fletcher burnors, using a low heat and taking olenty of time. In this way fusion and loss of chlorites was provented.

Phosphoms. The crucibles from the ash determinations were leached with atrong hydrochloric acid and a little nitric acid. The solutions were neutralized and ammonium nitrate was added. The phosphorus was precipitated at $65^{\circ} \mathrm{C}$ 
with acid ammonium molybdate. The yollow phospho-molybdate was filteres off, washed, dissolved in ammonia and hot water and the phosphorus was roprecipitated with magnesia mixture. The precipitate was ignited strongly in a gasoIIne muffle and welghed as the pyrophosphate (U. S. Department of Agriculture, Bureau of Chemistry, Bulletin 107, rovised, p. 2).

The time elapsing between the grinding of the sample and the preliminary part of the analysis, 1.e., to a point where the semple was safe, was made as short as possible. The samples were kept in Whitall and Tatum sample jars provided with rubber gaskets, glass tops and metal clamps so no 10 ss of molsture could occur. They were kopt in cold storage at just above froozing; so it can be safoly sald that the frosh sample was analyzed. An outline of the program for slaughtoring woek will 1llustrato this. The animal was killed Monday morning. The offal samples were ground, sampled and started on the analysis that afternoon and the following day. The chomical and slaughtor house force always worked nights; so by Wodnesday noon the offal samples, were safe. On Wednesday the carcass was cut up, the separations and composites made and the grinding of samples begun. By the end of the week, analyser were all well on their way and our rush work was over. 


\section{Mothod of Analysis for Bone Samples.}

Molsture. Samples for molsture wero wolghed out diroctly and rapidiy, in tripliozte, in tared porcelain evaporating dishes the size of the sample varying according to the coarseness or fineness of the bone. For finely ground samples 25 to 40 grams wore considered sufficlent while for coarse samples 100 grams or even more were sometimes taken. The dishes containing the welghed samples wore at once placed in vacuum destecators and dried as in the molsture determination above. The dish and dry bone was welghed rather rapldiy in the open and tho drying was continued unt1l the 1088 in weight was less than 25 or 30 milligrams.

- Fat. The dry samples from the above doterminations wore transforred carefully to scxhlet extractors having a disk of hard fllter papor in the bottom for filtering the other extraot. Redistilled anhydrous ethor was used for the extraction, the extract boing collected in welghed flasks. The extraotion was continued for thirty hours. The ether was distllled off and saved and the flasks were drled for twonty hours in vacuo and wolghod.

The residue from the extraction was saved, the triplicates were combined and the whole was ground in a stool mill until fine enough to pass through a mililmotor mosh slove. Th1s alr dry samplo was kopt for further detorminations of molsture, fat, nitrogon ash and phosphorus. 


\section{"42"}

N1trogen. The nitrogen was determined as given in deta1l above using $0.5 \mathrm{gram}$ samples.

Molsture and Ash. Two grem samples were weighed out in tared porcelain crucibles and dried at $100-110^{0} \mathrm{C}$. The difference in welght between crucible plus sample and dry weight of crucible plus sample gave the moisture. The samples were then ashed by igntting over fletcher burners until practically free from carbon and the ignition. Was completed in a muffle at a dulf red heat. A clear white ash was readily obtained by this means in a short time.

Phosphorus. The ash from the above determination was dissolved by digestion in hot, dilute nitric acid and the solution was made, up to $250 \mathrm{c} . \mathrm{c}$. Aliquots of $25 \mathrm{c.c}$. were taken and the phosphorus determined as given in detall above.

\section{Discussion and Interpretation of Data} Feed and Weight Talbes.

Tables 1,2 and 3 give by ten day periods, in pounds the average welghts of the steers; the grain and hay offered, refused and consumed; the consumption dally per 1000 pounds and per pound of gain; the maintenance requirements; the consumption above malntenance; the consumption above maintenance per pound of gain; and the protein, fat nitrogen free extract and fibre consumed. For maintenance for a 750 pound steer 7.50 pounds of grain and 3.75 pounds of hay were taken as the dally requirement per 1000 pounds; 
For a steer 800 to 1000 pounds seven pounds of grain and 3.50 pounds of hay, and for a steer over 1000 pounds 6.50 pounds of grain and 3.25 pounds of hay. These flgures were obtained from maintenance trials on six steers including the three antmals concerned in this thesis, the data being worked out and the above values proposed by the Department of Animal Husbandry at the University of Missouri. The weights by days will not here be given.

The average weight at the beginning of a period is the average of ten consecutive weights, the first weight In each perlod being the sixth of the weights averaged. The average welght at the close of a perlod is the a verage of ten consecutive welghts, the last welght in each period being the fifth of the ten welghts averaged and the first welght of the following perlod is the sixth of the ten weights averaged. Hence the final weight for one perlod is also the inftial welght for the perlod lmmediately following. The protein, fat, nitrogen free extract and fibre. consumed are calculated from tables four to elght and are the difforence botween weights in feod offered and weights in feed refused.

At the bottom of the tables are found the total, average per day, and average per day per 1000 pounds of the feeds consumed and the constituents consumed.

It w1ll be seen in taple I that No. 18 consumed on the average dally 5.75 pounds of grain and 2.43 pounds of hay. The average dally consumption por 1000 pounds was $\mathbf{7 . 4 9}$ 
pounds of grain and 3.17 pounds of hay while the maintenance figures are 7.50 pounds of grain and 3.75 pounds of hay. With those animals the hay was only four-tenths of the grain. The flgures for grain agroe very woll but it will be seon that this steer consumed on the average daily 0.58 pounds of hay less than maintenance roquirements keoping his body weight constant, however. His cost of maintenance is, then, below our average figures.

Steor 121 (table 2 ) during 160 days of maintenance consumed on the average daily 6.10 pounds of grain and 2.68 pounds of hay, or an average dally consumption per 1000 pounds of 8.04 pounds of grain and 3.53 pounds of hay. His cost of maintenance is highor than our average. During the 153 days of the full fed period he consumed on the average dally 18.34 pounds of grain and 7.21 pounds of hay, gaining 497.1 pounds in weight.

This gain was made on a consumption above maintenance of 1754.12 pounds of grain and 577.18 pounds of hay or 3.53 pounds of grain and 1.16 pounds of hay per pound of gain.

Steor 48 (table 3 ) during 150 days of maintenanco consumed on the average dally 6.82 pounds of grain and 2.97 pounds of hay, or an average datly consumption per 1000 pounds of 8.15 pounds of grain and 3.55 pounds of hay. H1s cost of maintenance is therefore above our average. . During the 567 days of the full fed pertod, he consumed on the average dally 16.93 pounds of grain and 7.01 pounds of hay, gaining 343.5 pounds in welght. This gain was made on a consumption above maintenance of 4482.03 pounds of grain and 1412.27 pounds 
of hay," or 4.75 pounds of grain and 1.50 pounds of hay per pound of gain.

\section{Foed Anaiys1: Tables.}

Tables $4,5,6,7$ and 8 give the analyses of all foeds fod to the steors, all foods refused, tho welghts of the constituents consumed and refused in each food and the total const1tuents consumed by ton day per1ods. At first samples wero froquently ohanged durling a ton day porlod. In suoh a case the weight of feed was divided proportionately accordIng to the date of the division and welght of feed fed on each day. Adding the two parts gave the total consumption of the portod.

Stoor 18 refused no feod and the constituents offered and consumed aro the same. Steors 121 and 48 rofused foed after the boginning of the full fod perlods, showing that at times the amount of feod offered was more than appotite or capaolty could take care of.

In table 9 are found the maintenance requirements In proteln, fat, nitrogon freo extraot and orude flbre for threo different maintenanco rations. These aro calculated. from the average analyses of the feods fod in this exporiment during four yoars using the rations given on pages 48 and 38. By reforring to table 1 it w11l be soen that for steor 18 the avorage dally oonsumption per 1000 poundis was: protein, 1.250 pounds, fat 0.361 pounds; nitrogen free extract 6.209 pounds; and crude f1bre 1.875 pounds. These are olose to the fleures In table 9 which are: proteln, 1.343 pounds; fat, 0.380 
pounds; n1trogen free extract, 6.536 pounds; and crude fibre, 1.465 pounds. The flgures for steer 121 (table 10) are: proteln, 1.334 pounds; fat, 0.378 pounds; nitrogen Troe extract, 6.804 pounds and cmude fibre 1.435 pounds. For steer 48 (table 1l) they are: proteln, 1.350 pounds; fat, 0.383 pounds; nitrogen freo extract, 6.867 pounds and crude flbre $1.434 \cdot$ pounds.

In tables 10 and 11 are found the total consumption, malntenance requirements, and consumption above malntenance, for each constituent of the feed for steers 121 and 48 . steor 18 was on maintenance throughout the experiment and 80 does not appear in these tables. ' One set of basal requiremonts are floured from the malntenance flgures and the second from the previous malntenance perlod of the steer. These latter are roduced to 93.3 por cent and 86 per cont as the maintenance requirement drops to the level of 800 pound steers and 1000 pound steers. At the foot of the tables are found the totals. The close agreoment betweon the two sets of excoss of constituent above requirement is due to the fact that the three steors consldered in this paper were used in figuring the maintenance requirements given on pages 48 and 43. The total consumption above maintenance for each constituent or the total productive consumption is also given in k110s for the data calculated with the previous maintenance period as the base. For steer 121 the total productive consumption of protein 1s 389.723 pounds; fat, 88.299 pounds; nitrogen freo oxtract, 1385.534 pounds; orude f1bre, 238.087 pounds. 
For steer 48 the total productive consumption of protein is 681.863 pounds; fat, 188.472 pounds; nitrogen free extract, 3442.802 pounds; crude flbre, 659.406 pounds. Steer 12f had gained 497.1 pounds and steer 48, 943.5 pounds. Thus - 121 required above maintenance for each pound of gain 0.583 pounds protein, 0.178 pounds fat, 2.787 pounds nitrogen free extract and 0.479 pounds of crude fibre. And 48 required above maintenance for each pound of gain 0.723 pounds protein, 0.200 poundsfat, 3.649 pounds nitrogen free extract and 0.699 pounds crude fibre. The first gain in weight of steer 48 was less costiy than this for 1 t is tho last gain in weight that is expensive, To put on the final touches in finish and fatness makes a good appearance but is unecononical. Steor 48 being out of condition part of the time will likely account, partly for the greater cost of each pound of gain. 


\section{CARGASS AND OFFAL.}

\section{Analyser and Welghts.}

The oarcasses of these three animals were graded by a professional outter from swift and Company of Kansas C1ty. The carcass of. Steer 18 graded as No. 3 , that of steor 121 as No. 1 but a little under finish and that of Steor 48 as No. I but greatly overdone and too fat.

Tho carcdss of steer 48 showed no slgns of tuberoulosis but some of the organs showed somo tubercules and thus confirmed the provious susplotons concerning this steor. Table 18 gives all slaughter house wolghts in grams taken of the three animals also the welghts of the different outs of meats with the welghts of lean, fat and bone separated. The offal welghts are for the total offal parts unless noted otherw18e. The carcass.wolghts are for the right half only. In general the welghts of the parts or organs increase with tho wolght of the animal. There 1s, howevor, loss difforonce betweon stoors 121 and 48 (the two full fed steors) than botwoon stoors 18 and 121. Stoor 121 had boon fod sufflolont to give him his full growth without laying on of muoh fat.

Tablos 13, 14 and 15 glve the laboratory numbers and analyses of all parts of the throo antmals analyzed. From these and the preoseding talo all the subsequent tables are derived.

In tablo 16 the systomo of the throe animals whion rero analyaed in parts aro oomposited and the composition of 
the total system obtained. Take for example, the digestive, and excretory systom of stoor 18. The analysis of the partial system (for the organs composing this systom soe page 33 and following), of the liver and of the kidneys is given. By adding tho welght of molsturo in these throo parts and dividing by the total welght of the system tho per cent of moisture In the entire system was calculated; and so on for the othor constituents, and systems. The dry substanco is the difference botweon the total and the molsture and the protein 18 nitrogen multiplied by 6.25 .

Table 17 is the table used for caloulating the composition of the frosh bone samplos. Part of tho analysos were made on tho frosh sample and part on tho air dry samplo. These lattor wero caloulated to a molsturo and fat froo basis and back to the frosh basis.

Tablos 18 to 26 aro tho tables usod in caloulating the welghts of the different constituents in the loan, the fat and the bone of each wholesale out of meat, of the foroquarters, of tho hindquarters, of the caroass and of the an1mal. These are oaloulated for tho cuts on both sides of the animal and so the weights aro double those given in table 12. Tho totals woro bullt up as shown in the discussion of table 16 (above.). The peroontages aro taken from the oomposite samplo analyzed.

Tables 27 to 33 show the bullding up of the total wholesale out, the quarters, the carcass and finally the 
total empty animal as analyzod. The mothod of bullding up tho composite is that doscribed abovo.

Sinco analyses woro made on composite samples and not on the Individual parts of each cut or systom, an exact comparison between the animals can be made only of the composite samples. Tho basis of analysis of Stoor 18 is best used as a standard, for fower samples more analyzod with this animal than in the caso of the others. To bring the data together in shape for comparison as outlined above, tables 33 to 39 wero made.

\section{Percontage Composition.}

Table 33 shows the percon rage composition of the various organs and cuts of meat anfyzed using steor 18 as a basis. The blod of the maintenance steor, No. 18, is higher in molsturo content and lower in dry substance than 1s the blood of elthor of the other two steors. The blood of No. 48 is 2 por cent lower in molsturo content and the blood of No. 121 is 1.5 per.cent lowor than the blood of No. 48. Steor 18 is shown to have 0.4 per cent fat in $h 1 s$ blood while the othors show none. This may well be due to Incomplete drying of the sample. In none of the blood samples subsequently analyzed has there beon found any ethor extract. It may bo that our mothod does not permlt the obtalning of the fat in the blood in the other extract and so It can only be sald that the ether extract as mun hore shows no fat in the blood. The proteln content varies invergely as the molsture erom 18 per cont to 20.3 por cont. 
The ash is 0.688 per cont in the blood of No. $18,0.775$ per cent in the blood of No. 48 but only 0.248 per cent in the blood of No: 12l. We can not account for the low percontage In the case of No. 12l. Analyses of other blood samples have, however, glven equally low rosults. The ash content 1s considerably higher in the full fed steer than in the maintenance steer. The porcentage of phosphorus in the blood is practically the same in all three cases; 0.22 por cent for No. 18, 0.28 per cent for No. 121, and 0.21. per cent for No, 48. We should expect the blood of No. 121 to to show the lowest phosphorus content since the ash is lowest here, but it does show the highest content.

Tho hide and halr runs noticeably high in molsture and protein. The molsture contont is 65.4 per cent in the hide of No. 18, 59.8 por cent with No. 121 and 59.2 por cent with No. 48. The fat content, as is to be expected, Incroases directly with the fatness of the steor; No. 18, 2.88 per cent; No. 121, 4.97 per cent; No. $48,8.60$ per cont. On a molsture free basis the fat mins: No. 18, 8.324 per cent; No. $121,12.350$ per cent; No. 48, 21.099 per cent. The protein content runs from about 32 per cent to 34.6 per cent being lowest in steer 18 and highest in steer 121. On a molsture free basis the protein runs; No. 18, 91.959 per cent; No: $121,85.968$ per cent; No. $48,81.391$ per cent. On a mo1sture and fat free bas1s: No. 18, 100.30 per cent; No. $121,98.080$ per cent; No. 48, 103.15 per cent. This shows that the protein factor of 6.25 does not hold for 
hide and halr. The ash and phosphorus content of the hide and hair decreases with the fatness of the steer, consequently with the fatness of the hide: The notable exception is the ash of steer 48 which runs unaccountaily high. The ash runs 0.868 per cent, 0.758 per cent and 1.197 per cent. The phosphorus is 0.068 per cent, 0.056 per cent and 0.048 per cent.

The skeleton of the three animals runs fairly constant in molsture, fat, protoin, ash and phosonorus, the values being: molsture, 28 to 29 per cont; fat, 21 to 25 per cent; protein, 19 to 22 per cent; ash 25 to 27 per cont; phosphorus, nearly 5 per cent. The composition of the skeleton of those three animals secms to be practically indevendent of the condition of the animal. But steer 18 runs 4 per cent higher in fat and 3 por cent lower in nitrogen than the fattor animals. As has been noted on table 17, the phosphorus data of steor 18 is believed to be unreliable and so no discussion will be made here concerning the low porcentage of phosphorus ( 2.870 per cent).

The clrculatory systom decroases very rarkodly in water contont and increasod in fat contont with increasing fatness of the steers, 62 per cent of the system being fat in stoer 48. This shows to what extent fat is laid on around the pertcardium. The protein, ash and phosphorus ciecreases relatively as the fat increases, but on a molsture and fat free basis there would bo shown an actual increase in these constituents. The semo things aro true regarding the resolra- 
tory system. But this systom shows rolatively less fat and more protein than the preceeding system shows. The nervous system runs rather constant in moisture content, about 69 per cent. The ether extract, however, runs: 17.6 in Steer 18, 19.5 per cent in steer 121 and only 13 per cent in steer 48. This may be due to differences in mechanical soparation. Outside the sheath of thetcord is found some quantitios of fat. Had the sheath and fat been separated with the cord in the case of No. 18 and No. 121 and only the cord itself boen placed in the sample in the case of No. 48 this would account for the difference in the fat results. Such an inconsistency might have occurred in the first slaughtoring or two. The cord alone was soparated in all subsequent casos. The protoin is about 11 por cont in the first two While it is 12 por cont in the case of No. 48. The ash and phosphoms are fairly constant.

The total digestive and excretory systom runs 67 to 68 per cent molsture, 15 to 17 per cont fat, 13 to 14 per cent protein, $I$ td 1.5 per cent ash and 0.15 to 0.20 per cent phosphorus. It must be remombored that the fat had boen stripped off this systom and so the excess of fat in tho Pattor steors will not bo shown in the percentago tables. Tho highor porcontago of fat in tho case of No. I2l may oasily bo due to tho difforonco in tho mochanteal soparation in the 3laughtor house. Tho livor of the throo animals mans constant in composition: 68 to 69 por cont moisturo, 3.5 to 4.5 por cont fat, 18 to 20 por cont protein, 1.25 to 1.40 por cont ash and 0.30 to 0.35 por cont phosphorus. The kidnoys 
also run falrly constant in composition although Steer 48 runs 4 por oont lower in molsturo and h1ghor in fat than the other two. Th1s and the low percentage of fat in No. 121 ( 5.56 per cent) may be due somewhat to varlations in the removal of the kidney fat. The values mun 71 to 75 per cent molsturo, 5.5, 8.7 and 12 per cont fat, 15 to 17 per cent protein, 0.95 per cont to 1.15 per cent ash, and 0.20 per cont to 0.88 per cont phosphorus.

In the offal fat and kldney fat the dry substance and fat 1norease with the fatness of the steor while the molsture, proteln, ash, and phosphorus decroase. The kidney fat has a greater percontage of dry substanco and fat than the offal fat. The fat in these samples runs from 80 to 95 per oont.

Passing to tho oarcass samples it is seon that the ghin, shank, hoad and tall loan and fat runs highest in molsturo content, being 67.5 per cont, 62.3 per oent and 57.8 per cent for steors 18,121 and 48 respootively. It muns lowest In fat in all oases, beling 12 por cent, 18.2 per cont, and 23.5 per cont. The protein is h1ghest horo 11kew1so-20.1 por cont, 18.3 per cont and 17.8 per cent. The ash and phosphorus is near the top in the oase of No. 18 and at the top with the other two steers. Th1s is thensobnest sample of all the composite samples analyzed. The fat inoroases rolatively with the fatness of the steors while the othor oonstituents deorease. One exoeption 1s the ash of steor 48 Whioh 1s the highest of the three. 
$" 55 "$

The round and rump lean and fat ranks next in low percentage of fat and high percentage of the other constituents. A close third is the chuck and neck lean and fit. Next comes the rib, loan and fat, then the loin loan and fat; and last the flank and plate lean and fat. The excoption In the case of steer 48 is to be noted in that the loin and rib trado places. The flank and plate cut runs from 30 per cent to 60 per cent fat showing what a very fat cut it is. The protein muns from 15 per cent to 8 per cent, the ash from 0.65 per cent to 0.42 vor cent, tise ash ror. 0.65 per cent to 0.42 per cent and the phosphorus from 0.124 per cent to 0.064 per cent. The fat and dry substance Increase in per cent with fatnoss of the stoer.

Tho total animal has 56.40 per cont moisture in No. $18,48.38$ por cent in No. 121 and 40.41 per cent in No. 48. The fat runs 18.59 per cent, 30.66 per cent and 42.34 per cent; the protein, 18.85 por cent, 16.02 per cont and 13.02 per cont; the ash, 5.72 per cent, 4.19 per cent and 3.49 por cent; and tho phosphorus 0.677 por cent, 0.748 por cont and 0.627 per cent. The. low percentage of phosphorus In the case of No. 18 is due to the low phosphorus content of the bone and is consequently congidered as erronoous. It can be seen that the relation pointed out just above holds for the entire animal, namely: the fat content increases relatively and the other constituents decrease rolatively with the incroasing fatness of the steers. 
" $56 "$

Distribution of Constituents in Entire. Animal.

Table 34 shows, the distribution of the analytical constituents in the ontire animal. The weight of constituont in the entire antmal is taken as the base and the ariount of the constituent in one system or cut is expressed in per cent of the total constituent.

In the blood the molsture is 7 to 8 per cent of the total molsture. It is about constint for the first two steers ( 8 per cent) while stoer 48 shows 7 per cont. The dry substance runs about 2 por cent of the total dry substance but for No. 48 it is 1.22 per cont. The protein is 5 to 6 per cent of the total protein. Horo stoer 121 is tho highost. The ash is 0.64 to 0.79 pes cent of tho total ash, steer l2l being a very marked exception with only 0.29 por cont. The triplicato detorminations of ash in the blood of Steor 121 were as follows:- 0.229 per cent, 0.237 por cent, and 0.278 per cent. So this data must be accepted. The phosphorus runs 0.173 por cent, 0.186 per cent and 0.117 per cent of the total phosphorus. This is $2 \mathrm{~s}$ we should expect from the ash data.

With the hide and halr the molsture is $10.16,7.39$ and 8.32 per cent of the total molsture; the dry substance is $6.96,4.72$ and 3.88 per cent of the total cry substance; the fat is $1.36,0.97$ and 1.15 por cont of the total fat; the protein is $14.81,12.99$ and 14.46 per cent of the total protein; the ash is $1.33,1.09$ and 1.35 per cont of the total ash; and the phosphorus is $0.880,0.450$ and 0.430 per cent 
of the total phosphorus. In general each constituent forms uent

relativoly less of the total eonbentas the animal increases in size. The antmal increases in welght faster than it increases Its surface area, hence its hide, and so the relative proportion decreases.

In the circulatory system the moisture forms 0.89 to,0.72 per cent of the total molsture; the dry substance, 0.88 to 1.08 per cent of the total dry substance; the fat, $1.43,1.20$ and 1.38 per cent of the total fat; the protein, 0.59 to 0.44 per cent of the total protein; the ash, 0.116 , 0.104 and 0.109 per cent of the total ash.; and the phosphorus, 0.16 to 0.11 per cent of the total phosphorus. The general tendency is the same as in the case of the hide and hair.

The respiratory system, however, shows a tendency diametrically opposed to the tondency of the two systems preceding. The constituent here in almost every case forms a rolatively greater part of the total constituent as the animal incroasos in welght. Howover, Steor 121 shows a rolatively smaller percentage of moisture aid protetn here than does No. 18. Th1s shows a marked development of the lungs as the animal increases in welght and the dovelopmont is relatively groater than the increase in weight. The per conts of the total constituents are: molsturo $1.39,1.23$ and 1.85 por cont of the total; dry substance $0.61,0.66$ and 1.28 por cent of the total; fat, $0.365,0.603$ and 1.336 per cont of the total; protein, $0.960,0.846$ and 1.420 per cent of the total; ash, $0.176,0.181$ and 0.290 por cont of the total; 
and phosphorus $0.024,0.213$ and 0.279 por cont of the total. The norvous systom again shows the same tondency as the hide and hair and circulatory systom. Tho constituont is a smallor por cont of tho total constituent.as the woight of tho animal incroases, The values aro: molsture $0.289,0.202$ and 0.184 per oont to the total; dry substanco $0.176,0.089$ and 0.054 por cent ot tho total; fat 0.234 , 0.092 and 0.033 per cont; protein $0.134,0.094$ and 0.107 por cont; ash 0.076, 0.054 and 0.055 por cont; and phosphorus $0.154,0.076$ and 0.072 per cont of the total.

Tine order in tho total digestive and excrotory systom follows the othor systems as far as the dry substanoo, fat and ash aro conoornod. The molsturo,'protoin and phosphorus, howover, aro highost with stoor 121 and in steors 18 and 48 thoy aro about oqual. Tho values aro: molsturo 8.86, 11.06 and 9.37 por cont of tho total molsture; protoin 5.47 , phosphoris

6.31 and 5.41 of the total protein; Nasil 1.69, 2.11 and 1.75 phoophorus por cent of the total $\mathrm{f}^{3}$; dry substanco $5.62,5.23$ and 2.89 por cent of the total dry substanoo; fat $6.43,4.61$ and 1.97 por cont ot tho total fat; and ash $2.04,1.70$ and 1.56 por cont of the total ash.

Tho rolative amounts of tho constituonts which aro found in tho livor first incroasos for stoor 121 and romatns about constant for Steor 48. The dry substance and fat are oxcoptions, the values for stoor 48 falling bolow those of No. 18. The f1gures aro: molsturo 1.096, 2.003 and 1.943 por cent of the total molsturo; dry substanoe $0.637,0.88$ and 
0.572 per cont ot the total dry substanco; fat $0.167,0.22$ and 0.113 por cont; protein $0.899,1.777$ and 1.563 per cent; ash $0.196,0.447$ and 0.449 per cont; and phosphorus 0.411 , 0.673 and 0.546 per cont.

In the kldneys a constant relation does not appear. The constituents increaso absolutely, but relatively in some case the rolation romains about constant, in others it increases betwoon No. 18 and No. 121 and thon docroasos for No. 48, and in others it decroases. The percentages of the total constituents are: molsture $0.346,0.35,0.30$ por cent of the total; dry substanco $0.149,0.102,0.083$ por cent; fat 0.122 , 0.044 per cont, 0.049 per cent; protein $0.205,0.238$ and 0.198 per cont; ash $0.049,0.051$, 0.056 per cont; phosphorus $0.081,0.068$ and 0.053 per cont.

With the offal fat and kidnoy fat there $1 \mathrm{~s}$ a constant and nottoeablo incroaso in tho rolativo porcentages as the animal incroases in wolght. A rolatively groator part of tho total constituonts is in theso samples for the animal lays on a largo amount of fatty tissuo horo when it is fatton1ng. By adding the percentages for fat of these two samples It w111 be seon that 12,20 and 24 per cent of. the total fat of the animal is found here in steors 18, 121 and 48, respootIvely.

In the case of the skeleton the constituents form a decreasing proportion of the total as the animal incroases In welght. From 84 to 90 per cent of all the ash and phosphor us 18 in the skeleton, ono-fifth to ono-sixth of the proteln, 
n60"

27 down to 5 por cent of the fat, 32 to 13 per cent of the dry substance and 10 to 7.5 per cent of the molsture.

The shin, shank, hoad, and tail lean and fat sam-

ple is relatively a waste out or at least a poor cut. It would therofore be a good part of the animal to eliminate during growing or at least to reduce to a minimum. It can be soen by glancing through the figures that the constituents of this sample form from 4 per cent down to 0.60 per cent of the total constituents and there is decrease as the animal increases in welght.

Tho round and rump loan and fat contains a constant proportion of the total constituents about 15 per cent of the molsture, 10 per cent of the dry substance, 9 to 10 per cont of the fat, 13.5 per cont of the protein, 2 to 2.5 per cent of the ash, and 3.3 to 2.5 per cent of the phosphorus. The same is true of the chuck and neck lean and fat. Hero the values are 17 to 18 per cent of the total moisture, 11 to 12 por cent of the dry substance, 11 to 12 per cont of the fat, 14 to 16 per cent of the protein, 2 to 3.5 per cent of the ash, and 2.7 to 3.4 per cont of the phosphorus. Thus the constituents in the chuck and neck are a relatively lareer the oxse in

percentage of the total constituents than is/the round and rump.

In the rib lean and fat the molsture, dry substanco, fat, protoin and aon form a rolatively increasing proportion of the total constituent as the animal grows in woight. The phosphorus relatively decreases. The values are 5 to 6 
per cent of the total molsture, 4 to 7.7 per cent of the ary substance, 4.6 to 9.1 per cent of the fat, 4.79 to 5.05 por cent of the protein, 0.67 to 0.96 per cent of the ash and 1.1 to 0.92 per ceint of the phosphorus.

The constituent in the loin lean and fat increase relatively as the animal grows and fattens. The porcentages are 10 to 11 per cent of the total molsture, 8.5 to 12.7 per cent of the dry substance, 1 I.8 to 14.7 per cont of the fat, 8.8 to 9.68 per cent of the protein, 1.28 to 1.88 per cent of the ash and 2,15 to 1.85 per cent of the phosphorus.

The flank and plate lean and fat shows the same relations as the rib lean and fat, namely: the moisture, the dry substance, fat, protein and ash form a relatively greater proportion of the total as the animal fattens. The values run $6.93,9.33$, and 0.38 per cont of tho total moisture; 8.11, 13.24 and 14.74 por cent of the dry substanco; 12.05,. . 17.63 and 18.15 per cent of the fat; $6.02,8.51$ and 7.84 per cont of the prote1n; $0.84,1.35$ and 1.52 per cont of the ash; and $1.36,1.44$ and 1.28 per cont of tho phosphorus.

\section{DISTRIBUTION OF OFFAL PARTS.}

In table 35 are given the welghts in kilograms and pounds of various of the offal parts of the arimals and the porcentages compared to the IIvo and warm empty weifhts. The warm empty velght of the animal is obtained by subtracting the "flll", the contonts of the stomach, intestines, and bladdor, from the l1ve welght. The empty welght forms an 
increasing percentage of the total, the fatter and heavier the animal, being 88.18 per cent for No. $18,89.30$ por cent for No. 121 and 91.98 por cont for 48 . The carcass is 59, 60 and 64 per cent of the live weight and 67,68 and 69.7 per cent of the empty weight. Thus with increasing weight of the animal a smaller proportionate part is fill and a greator part is carcass. Consequently the animal "dresses out" higher and higher. The hide and hair runs $7.49,5.25$ and 5.08 por cent of the ilve woight and $8.50,5.88$ and 5.53 per cont of the empty wolght. On the other hand, the offal fat incroasos rolativoly and absolutoly boing $1.66,4.81$ and 7.64 por cent of the live weight and $1.89,5.39$ and 8.30 per cont of the empty wolght. The blood forms a relatively decreasing proportion of the animal. It increases in wolght about 57 por cont from steor 18 to steer 121 with only a 5 per cent inoroaso from there to stoor 48 . The blood is $4.55,4.29$ and 3.17 por cont of the live wetght and $5.16,4.81$ and 3.44 por cont of the ompty woight. The heart increases constantly in wolght but is a relatively smaller proportion of the whole as the animal grows larger. It is $0.436,0.280$ and 0.210 por cont of tho live woight and $0.495,0.314$ and 0.228 per cent of tho ompty wolght. The respiratory systom boars out the statoment given in the discussion of table 34. This systom inoroases absolutely in wolght but also rolatively in proportion to the total. Howover, the porcontages for steor 121 are not h1ghor than for steor 18 but a littlo lower. Referrod to the empty wolght this systom 1s $1.02,0.91$ and 1.47 per cont of the total. 
The stomach about doubles in weight in going from Stoor 18 to steer 121 and then stays constant for steer 48 . The porcontage compared to the total first incroases slightly and thon falls. The values roforred to tho empty welght aro 2.53, 2.80 and 1990 per cent. The woight of the intestines is about the same for steors 18 and 48 while No. 121 muns three to four kilos heavier. The per cent to the empty wolght docroases, boing $2.02,1.96$ and 0.95 per cont. The length of the intestines was measured in the two larger steers and found to be about 185 foet in each. The longth per 100 pounds of empty welght is 16.77 foet and 11.22 foot for No. 121 and No. 48 respectively. The liver increases noticeably in. wolght while the proportion increases and then falls again. The por cont of ompty weight is $0.87,1.38$ and 1.10 per cent. Tho gall bladdor and gall increasos in weight and the proportion Incroases and then decroases, being $0.031,0.095$ and 0.077 por cent of the ompty woight. The spleen increases in woight and the percentage of empty weight runs $0.16,0.18$ and 0.14 per cent. The pancreas weighs about 250,420 and 300 grams in these animals. In the first two animals it is 0.082 per cont of the empty weight while in. No. 48 it is only 0.040 por cent of the empty reight.

\section{D1stribution of Cuts.}

Table 36 shows the distrtbution of the vartous wholesale cuts of meat in the carcass and in the empty animal. 
The foroquarters, as well as the hindquarters, of oach animal are almost one-third of the ompty animal and ono-half of the carcass. The forequarters are slightly the heavier and form a Iltle larger proportion of the whole. With Increasing welght of animal the foroquarters are an inoreasing proportion of the live welght, an lnoreasing and slightly decreasing part of the empty weight, and an incroasing and then decreasing proportion of the carcass weight. The hindquarters are an increasing proportion of the live welght, a constant and then increasing proportion of the empty weight, and a decreasing and then Incroasing proportion of the carcass weight. The hindquartors of steer 48 are a ereater proportion of the Iive, empty, and carcass welghts than is the case in oithor of the two other steers. The shins (fore shanks) are a smaller proportion of the total as the anmal increases in woight. They are 3.45 to 2.14 per cent of the empty welght and 5.15 to 3.07 per cent of the carcass. The plates are a greater proportion of tho total in the two heavy animals - about io per cont of the ompty welght and 15 per cont of the carcass - than in the thin animial, where they aro 7.36 and 10.96 por cent respectively. Tho chucks are a smaller part of the total in the two full fod animals than in the maintonance animal. They run 17.64, 15.59 and 15.96 per cent of tho empty welght and $26.28,22.92$ and 22.91 per cent of the carcass. The necks become a smaller part of the total as the animal Incroases in wolght, running $1.05,0.71$ and 0.65 per cont of the empty weight and $1.57,1.04$ and 0.93 per cent of 
tho deroas. The rlbs are a greater part of the total vith increasing weight of animal, being $6.23,6.83$ and 7.88 por cont of the empty animal and $9.28,10.05$ and 11.32 per cent of the carcass.

The shanks run as do the shins but the values are 2.67 to 1.55 por cent and 3.97 to 2.23 per cent in place of the 3 and 5 per cont of the shins. The rounds decrease with incroasing weight of animal - 12.76, 11.57, 10.27 per cent of empty weight and 19.01, 17.01 and 14.74 per cent of cajcass. on the othor hand, the values for the rumps increase 2.33 , $2.35,2.63$ por cont of the empty animal and $3.47,3.45$ and 3.78 por cent of the carcass. The proportion of loins increases noticeably being $10.96,12.09$ and 12.89 per cent of the empty volght and $16.33,17.77$ and 18.51 per cent of the caroass. The flanks follow the same rule, belng $1.62,1.71$ and $3.43 \% 0 f$ tho empty animal and $2,41,2.52$ and 4.92 por cont of the carcass. With the kldney fat the same is true. The values run $1.05,1.65$ and 2.47 per cont and $1.57,2.42$ and 3.55 per cont of the empty animal and carcass respectiveiy.

\section{Distribution of Total constituents.}

Table 37 shows the porcontages of the constituents in the warm ompty animal and in the empty animal analyzod. The latter value 1s obtained by subtracting the horns, roofs, teeth and dew claws from the former. Tho difference botween the warm ompty wolght of the animal and the bullt up animal 
analyzed (which is the total animal given in tables 28, 30 and 32 ) plus the horns, hoofs, teeth and dew claws, gives the loss on cooling and sampling. Great care was taken to prevent any loss of the sample belng cut up or separated, evory particle and plece was returned to the proper container whenever any was aropped or flew away from the cleaver. Some "sawdust" was 108t. Th1s 10s8 is considered as molsture and is added to the welght of molsture obtained from analysis to give the grand total of molsture. on this basis the percentages aro given.

The loss on cooling is a falrly constant porcontage of the empty woight, running $3.37,2.67$ and 2.83 per cont tuken in the usual ordor. The percentage of total molsturo In the empty animal, less horns and so forth, runs one or two por cont above that in the animal as analyzed and is 57.45 , 50.08 and 42.31 per cent. The dry substance on the same basis is 42.55 por cont, 49.92 per cont and 57.69 por cont; the protoln is 18.40 por cont, 15.59 per cont and 12.73 per cent; the fat is $18.15,29.84$ and 41.37 per cent; the ash Is $5.58,4.08$ and 3,41 por cont; and the phosphoms is 0.661 , 0.728 and 0.619 per cent. Thoso all rul a littlo lower than in the animal as analyzed on account of the groator wolght of the warm empty animal loss horns, hoofs, tooth and dow claws.

Tho skoloton 18 17.01, 11.66 and 9.79 por cont of the Ilvo welght; $19.88,13.06$ and 10.64 per cont of the rarm empty wolght. The skoloton of tho oaroass 1 s $22.04,14.79$ 
and 12.03 per cent of the carcass. The loan meat of tho animal is $39.21,35.36$ and 30.43 per cent of the l1ve woight; $44.47,39.60$ and 33.08 por cent of the wamn ompty weight. Tho earoass lean 1s 65.57, 59.96 and 47.08 of the carcass. The fat (hand separated and exclusive of the offal fat) is $7.34,16.56$ and 26.26 por cont of the live weight; 8.33 , 18.54 and 28.55 per cont of the wam empty weight! The fat of the carcass $1 . \mathrm{s} 12.36,27.25$ and 40.89 per cont of the carcass. The relative mount of fat incroases, while the lean and bone relatively decrease, with increastng woight of the antmal.

\section{Skeleton Comparisons.}

Table 38 gives the comparison of tho constituents in the skeloton to tho constituonts in tho total animal and in the carcass. According to the table the skeleton contalns $9.56,7.76$ and 7.13 per cont of the total molsturo; 32.71, 18.47 and 13.15 per cent of the total dry substance; 27.03 , 9.31 and 5.47 por cont of the total fat; $19.92,18.40$ and 16.45 per cent of the total proteln; $88.03,87.17$ and 83.86 por cent of the total ash; and $84.53(9), 86.52$ and 86.01 por cent of the total phosphorus. The skeleton in the animal thus contains a rolativoly smaller amount of the total molsture, a relatively less amount of the total ary substance, a decreasing proportion of the fat and a slightly decroasing proportion of the total protein, ash and phosphorus. The same rolation holds for the skeloton of the carcass compared to the carcass. The excoption in both cases is in the case 
of the phosphorus of the skeleton of steer 18. This data has been pointed out before as unreliable on account of a loss of all but one sample of the bone. We belleve that a true value would bear out the above relations. The proportion of each constituent in the carcass skeleton of the total constituent in the carcass is similar to that in the total animal. The carcass skoleton has of the constituents in the carcass: $11.409,9.298$, and 8.030 per cent of the moisture; $34.967,19.696$ and 14.550 per cent of the dry substance; $27.549,9.599$, and 6.474 of the fat; $22.736,20.931$, and 18.480 per cent of the protein; $90.055,87.972$ and 85.924 per cent of the ash; $84.172,86.843$, and 87.317 per cent of the phosphorus. The phosphorus of the carcass skeleton of Steer 121 is only 86.84 per cent of the total phosphorus of the carcass, one half per cent lower than in steer 48 . The proportion of the phosphorus in the skeleton to the total is a bout constant in those twro animals.

\section{Fat Distribution.}

Table 39 gives a special study of the analytical fat in the total animals. The total fat in the animal is $54.465 \mathrm{kllograms}$ in steer $18,151.116 \mathrm{k} 1$ lograms in steer 121, and $307.082 \mathrm{kllograms}$ in steer 48. The weight of fat in the total fleshy parts of the animal exclusive of the kidney fat 1s $27.660 \mathrm{kllograms}$ for steer 18, 94.471 kilograms for Steer 121 and $199.074 \mathrm{kllogram}$ for steer 48 . The percontage of fat in the entire animal and in the skeloton have been 
compared previously but are given here for comparison. The fat in the flesh and internal organs (exclusive of offal and kidney fat) is 60.72 per cent of the total fat in steer 18, 70.20 per cent for steer 121 and 70.69 per cent for steer 48. It is about constant in the fat animals and 10 per cont above that in the thin steer. The fat in the offal and kidney fat is a greater proportion of the whole as the animal Is fatter, being 12.24 per cent, 20.50 per cent and 23.84 per cont. The fat in the offal and kidney fat is 24.11 per cent fat in the fiesh of the onimal (less the kidney fat) in Steor 18, 32.69 per cont in steer 121 and 36.77 per cent in steer 48. The fat in the flesh is 50.79 per cent of the total fat for $s$ teer $18,62.71$ per cent for steer 121 and 64.89 per cent for steer 48. The fat in the skeleton is 27.03 , 0.31 and 5.47 per cent of the total fat in the threo animals. These flgures show, in simple words, that fat is laid on more rapialy on the internal organs and in the abdominal cavity than on the axternal part of the animal as it is fattened. The fat deposited in and over the flesh is a somewhat greater part of the entire fat but changes only from 51 per cent to 65 per cent. In the thin animal over one-fourth of the total fat $1 \mathrm{~s}$ in the skeleton while in the fatter animals only 9.31 per cent and 5.47 per cent is there. An animal on malntenance will bulld up his skeleton and store up pat in 1t bofore, 1t will devoto much materlal to the fleshy parts. 
n70n

Cost of Maintonance and Woight Gainod.

Tables 40 to. 48 inclusive give tho data used in computing the malntonance costs, the cost of each pound of gain and the enorgy stored in each pound of gain. The values for poroontago of digestible protein and onergy value for corn, alfalfa and Ilnseod moal wore obtainod from tho tables glven by H. P. Armsby in Farmers Bullotin No. of tho U. S. Department of Agriculturo. The energy value of coon, linsood and alfalfa aro glvon in thorms jer 100 pounds of food, a them bolng tho quantity of hoat requtrod to ra1so 1,000 k1lograms of wator 10 C in temporaturo. A therm is, thoroforo, 1000 largo oalorios or 1,000,000 small calorios. During tho maintinanco portod of stoor 18 this ailmal consumod dally in its food 0.691 pounds of digostiblo protoin and 5.881 thorms of onorgy. Steor 121 consumed 0.741 pounds of digostlble protoin and 6.278 thorms. Stoor 48 consumod 0.827 pounds of digestiblo protoin and 7.004 thorms. Armsby gives tho maintonanco roquiromonts of 750 poind: stoors as 0.40 pounds of digostible protoin and 4.95 therms daily. Our two 750 pound steors roqulrod from 75 per cont to 85 por cont moro digestible protoln and from 18 por cont to 26 por cont moro onorgy. The hoavior steor roqulrod 90 per cent moro digestible proteln and about 32 por cont more onergy than a stoor of corrosponding wolght on Armsby's roqulroments. Thls groat differonco may likely be due to the difforenoo in 
the breod of cattlo. The Heroford-Shorthorn grade stecr is a large framed animal while the cattle at Ponnsylvinla state Coliege aro small.

Tablo 41 gives the data for computing the total productivo digostible protein and total productivo onorgy consumed above malntenance by steses 121 and 48 durling tho full fod portod. Stoor 121 had consumod 199.39 pounds of productive difestible protoin and 1737.632 thems of energy. It had gainod 497.1 poundis. Thoro woro roquirod, thoroforo, 0.401 pounds of digestible protoin and 3.496 thems of enerey for oach pound of gain. Stoor 48 consumed 505.173 pounds of productive digentiblo proteln and 4418. 563 productive thorms. This steor galnod 943.5 pounds and thus roquirod por pound of gain 0.535 pounds of digestible protein and 4.633 thorms of onergy.

Tablo 42 shows tho wolght in kilograms of tho difforont analytical constituonts stoor 121 had in excess of Stoor 18. It is hore assumed that the threo steors had practloally tho same composition while on malntonance and this excoss is taken as showing the amount of the constituonts ratned by the stoor during the full fec rerfod. Stcor 121 thus had 74.79 k110s of molsture, $125.117 \mathrm{k} 110 \mathrm{~s}$ of dry substance, $96.651 \mathrm{kllos}$ of fat, $23.72 \mathrm{k} 110 \mathrm{~s}$ of protein, 3.884 kllos of ash and 1.704 k1los of phosphorus abovo steer 18. The therms stored in the fat and protein gained wero calculatod from Bonodict's and Osterberg's value for fat ( 9.523 por kilo) and the avorage of stolmann and Kohler's values for protoin 
( 5.665 por $\mathrm{k} 110$ ) as given in "The Principles of Animal Nutrition" by H. P. Armsby, page 244. Steer 121 stored 134.374 therms in the protein gained and 920.407 therms in the fat gained, or a total of 1054.781 therms.' The animal thus stored up an amount of energy equal to 60 per cent of the productive energy consumed.

Table 43 show the same things for steer 48 as table 42 shows for steer 121: However, Steer 48 weighed, during the maintenarice period, 63.3 pounds or $31.434 \mathrm{kilos}$ more than steer 18. It is assumed that this difference in weight has the same composition as steer 18. Steer 48 had therefore $110.079 \mathrm{kllos}$ of molsture, $290.775 \mathrm{kilos}$ of dry substance, 246.774 k1los of fat, 33.939 kilos of protein, $6.873 \mathrm{k} 1 \mathrm{k}$ os of ash and $2.392 \mathrm{k} 110 \mathrm{~s}$ of phosphoms above steer 18. This animal stored 192.264 therms in its protoin gined and 2350.029 therms in the fat stored, or a total of 42.293 thorms. It thus stored up an amount of energy equal to 57.5 per cent of the productive energy consumed. 


\section{$173 "$}

\section{Sunmaries.}

Blood. As to composition the water content decreases while the dry substance and protein incresse with fatness of the steers. The phosphorus is constant and the ash show no relation to condition. The constituents form a slightly decreasing proportion of the total constituents in the animal. The weight of the blood forms a decreasing proportion of the empty welght of the animal. The blood of No. 121 is 57 per cent more by wejght than the blood of No. 18. No. 48 shows but a 5 per cent increase over No. 121. The heart is a smaller proportion of the empty weight as the animal fattens.

Circulatory system. The percentage of fat in this system increases with the fatness of the animal while the other constituents decrease. The system forms a relatively decreasing proportion of the animal.

Hide and Hair. The percentage of dry substance, fat, and protein in the hide and hair increse while the other constituents decrease with increasing fatness of the animal. The welght of the hide and hair as well as the weights of its constituents form a smalier proportion of the total as the animal fattens.

Norvous system The composition of this system is constant. It forms a cecreasing proportion of the animal as the animal fattens.

Respiratory system. The porcentage of fat in this 


\section{"74"}

system increases with increasing fatness of the ailmal while the othor constituents deorease. The system (as well as the constituents ) forms a greater proportion of the total as tho animal fattens. There 1s, however, not much differenco betweon stoer 18 and steor 121 .

\section{Digestive and Exarotory systom. This system has}

a constant composition. It forms a decroasing proportion of the empty animal as the animal fattens. The liver is an inoroasing proportion of the total and so is the gall bladder and gall. The sploen is about constant, as $1 \mathrm{~s}$ the pancroas for No. 18 and No. 121. The varlous organs increase in wolght it is true, but not in proportion to the increase in weight of the animal. The stomach inoroasos proportiunally from No. 18 to No. 121 but falls again for No. 43. Offal Fat and Kidnoy Fat. Those samplos show incroasing per cont.of dry substance and fat with inoroasing fatness of the steors. The other constituents decroase. They form a greater part of the empty animal (and of the total consituents) as the animal fattens. Twelve to trenty-four por cent of the total fat is here.

The carcass cuts will be troated in the ordor of highest peroontage of moisture, protoin, asin, and phosphorus and rowestior per cent of dry substance, and fat. Shin, shank, Hoad and Iail Lean and Fat.

This out comes first in the abovo order. The fat and dry substance Increase as the fatnoss of the steor. The cut is a decreasing part of the empty animal and carcass. 
Round and Rump Lean and Fat comes second in high per cont of molsture, oto. Th1s cut has a constant composition. It forms relatively less of the empty animal and carcass as the animal fattens. The rump cut alone increases, however, as the animal fattens.

Chuck and Nock Loan and Fat. This ranks third, has a constant coraposition and forms less of the empty animal and carcass as the animal fattens.

R1b Lean and Fat. This cut ranks fourth. The per cent of dry substance and fat incroase, the other constituents decrease, as the animal fattens. This cut forms a greater part of the empty animal and carcass as the animal Pattens.

Loin Lean and Fat. This cut ranks fifth. Otherwise it follows exactly the rib lean and fat.

Flank and Plate Lean and Fat. This cut ranks

sixth. Otherwise it follows the rib lean and fat.

Skeletion. The skeleton runs fairly constant in composition in all three animals in spite of the extreme thinness of steer 18. The skeleton and the varlous constituents increase in weight with the weight of the animal but the increase is proportional for all the constituents. The constituents form a decreasing proportion of the total constituents and the welght of skeleton is a smaller part of the enpty animal and carcass as the antmal fattens. From 90 to 84 per cent of all the ash and phosphorus is found here, onefifth to one-sixth the protein, and twenty-seven to five por 
cont of the total fat.

Lean Flesh. This is 44.5 to 33.1 per cent of the empty animal and 65.6 to 47.1 per cent of the carcass. It decreases proportionately as the animal fattons.

Fat Flesh, (exclusive offal fat.). This 18 8.3 to 28.6 per cont of the empty animal and 12.4 to 40.9 per cent of the caroass. It increases proportionately with the fatness of the stoor.

Total Antmal. The percontago of fat in the animal incroasos with the fatnoss of tho steor. The other constituonts docroaso. Tho loan animal 1s over half molsturo ( 56 - 57 por cont) and the fat antmal 40 por cont moisturo. Tho fat animal 18 ovor 40 por cont whilo the loan animal is only 18.6 por cont.

The "fill" is a smaller part of the animal and the carcass a largor part with tncroasing fatnoss.

Fat Distribution. In the thin animal 12 por cont of the total fat $1 \mathrm{~s}$ in tho offal and kidnoy fat, 12.5 por cont in tho adiposo tissuo, 27 por cont in the bones. Tho romalnder to in the loan flosh and internal organs. In tho fattor animal 21 por cont of tho total antmal fat is in tho offal and kldnoy fat, 38.8 por cont in tho adipose tissuo, 9 por cont in the bonos and the romainder in the loan flosh and internal organs. In tho fattost stoor 24 por cont of the total fat 1 in in tho offal and kidnoy fat, 46 por cont in the adiposo tissuo, 5.5 por cont in the bones, and the romalndor In tho loan flosh and intornal organs.

Maintonance cost of Stoor 18, Por thousand pounds Ilve wolght dally tho consumption, or cost, war 7.49 pounds 
grain and 3.17 pounds hay; or 1.25 pounds protein, 0.361 pounds fat, 6.299 pounds nitrogen froe extract, and 1.275 pounds of crude fibro; or 0.691 pounds of digestible protein and 5.881 thorms of energy.

Maintenanco cost of steor 121. In the same units as above tho cost was 8.04 pounds grain and 3.53 pounds hay; or 1.33 pounds protein, 0.378 pounds fat, 6.804 pounds nitrogon froo extract, and 1.435 pounds crude fibre; or 0.741 pounds of digestible protein and 6.278 therms of onergy. Maintenazce cost of Steor 48. Tho cost was, in tho above units, 8.15 pounds grain and 3.55 pounds hay; or 1.35 pounds protoin, 0.383 pounds fat, 6.867 pounds nitrogein Proe oxtract, 1.434 pounds crude fibro; or 0.827 pounds digestible protein and 7.004 therms.

Cost of Gain, stoor 121. The cost per pound of gain was: 3.53 pounds grain and 1.16 pounds of hay; or 0.583 pounds of protein, 0.178 pounds of fat, 2.787 pounds of nitrogen froo oxtract, and 0.479 pounds of crude ribre; or 0.401 pounds of digostible protein and 3.496 therms. This steor stored up in tho fat and protein gained 60 por cont of the onergy consumed above maintenanco. Cost of Gain, Stoor 48. The cost per pound of gain was: 4.75 pounds grain and 1.50 pounds of hay; or 0.723 pounds protoin, 0.200 pounds of fat, 3.649 pounds of nitrogen froe extract, and 0.699 pounds of crudo fibro; or 0.535 pounds of digestiblo protein and 4.683 thorms. This stoor stored up in the fat and protein gainod 57.5 por cont of the onorgy consumed above maintonance. 
The work of which this thesis is a part was origthally planned by President H. J. Waters of Wnahattan, Kansas, formerly Dean of the College of Agrlculture of the University of Missour1. The work was done under the limediate direction of Professor P. F. Trowbrlige of the Department of Agricultural Chomlstry. The author wishes to acknowledge his 1ndebtedness to them, to Mr. L. D. Haigh for part of the abstracts of l1terature and for other assistance, and to his past and present associates in the Department of Agricultural Chemistry. 
Table I. Slesr 18. Wright and Ferd Recoad - 10 Day Prriods.

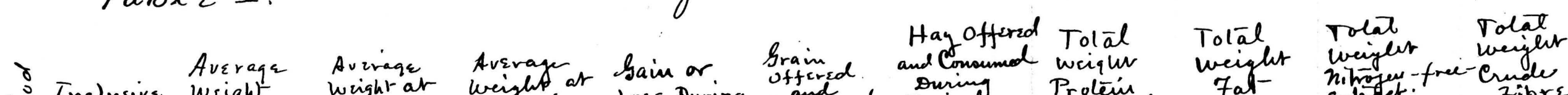

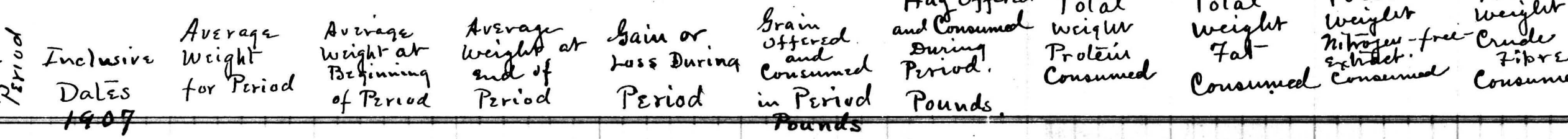

$12 / 1-2 \% \quad 764.6 \quad 763.6 \quad 762.9-0.7$

$22 / 11-2 / 20 \quad 756.0 \quad 762.9 \quad 746.6-16.3$

$32 / 21-3 / 2737,1746.6736 .9-9.7$

$43 / 3-8 / 12739.5736 .9742 .1+5.2$

$53 / 3_{3}-3 / 22747.9742 .1748 .8+6.7$

$63 / 28-4 / 1348.3748 .8750 .7+1.9$

$74 / 2-4 / 11750.6750 .7 \quad 754.7+4.0$

$84 / 12-4 / 21$

$94 / 22-5 \%$

$106 / 2-5 / 11$

$115 / 12-5 / 21$

$125 / 22-5 / 31$

$136 / 1-6 / 10$

$144,6 / 20$

$15-6 / 21-6 / 30$

$167 / 1 / 10$

$177 / 11-7 / 20$

$187 / 2-7 / 30$

$197 / 31-8 / 9$

$208 / 10-8 / 19$

$218 / 20-8 / 29$

$228 / 30-9 / 8$

$23 \quad 9 / 9-9 / 18$

$249 / 19-9 / 28$

$25-9 / 29-10 / 8$

$2610 / 9-10 / 18$

$271019-10 / 28$

$281029-117$

$2911 / 8-11 / 11$

Auerage

p 79 .
$761.0754,7 \quad 765.2+10.5$

$770,4765,2 \quad 769,9+47$

769,7

768.5

769.9

767,0

$-29$

780,5

784.5

767.0

$776,5+9,5$

$7820+5.5$

$777.5-4.5$

7580

.7775

$7475-30.0$

748.0

$747,5+758,0+10,5$

$\begin{array}{llll}7595 & 758.0 & 754.7 & -3.3\end{array}$

$750.9 \quad 754.7 \quad 752.8-1.9$

759.6

7528

$7649+121$

764.8

766,4

764.9

$760.2-47$

$760.2772 .9+12.7$

772,8

77.29

$7776+4,7$

$7780^{-} \quad 777.6$

$7662-11.4$

$770.8 \quad 766.2 \quad 789.8+23.6$

$801,47898 \quad 8029+13.1$

799.9

$8029796,4-6.5$

791.8

$796,4 \quad 791,3 \ldots-5.1$

788.7

785

778.1

767,3

$791.3 \quad 7820-9,3$

$7820 \quad 781.8 \quad-0.2$

781,84 days

Average perday
$58.0 \quad 54.00 \quad / 3.490$ $60.0 \quad 2750 \quad 10.238$

$60,02500 \quad 9.911$

$695 \quad 2500 \quad 10961$

$75.0 \quad 29,50 \quad 12 ! 59$

$75.0 \quad 3000 \quad 12220$

75.0

725

64,0

600

30.0012 .225

$28.75-11.785$

$2525 \quad 10,386$

2500

$60,0 \quad 2500$

$60.0 \quad 2500$

$49.0 \quad 19,50$

$40.0 \quad 1500$

$48.5 \quad 1950$

50.

50.

54.0

55

55

55.

55.0

550

55.

$52.5 \quad 21.00$

$50,0 \quad 20,00$

$50,020.00$

9,911

9911

9.483

7497

6023

7.442

7.662

2000

2200

7.662

8317

22.50

8439

8439

9450

2250,10328

$2250 \quad 10328$

$2250 \quad 10239$

8961

8,533

8533

$50,0 \quad 20.00 \quad 8502$

20,0

8.00

3.412

16330690.00272 .452

6.75

0.75

2.43

0,989

$3,17 \quad 1.250$
$3,200 \quad 5.9,47 / \quad 19,928$

$2.82551 .044 \quad 10.932$

$\begin{array}{llll}2.7822 & 50.120 \quad 10.078\end{array}$

$3.150756,590 \quad 10,320$

3.44762 .00511 .999

$3.456 \quad 62.190$

12.169

$\begin{array}{llll}3.456 & 62 ! 90 \quad 12 ! 69\end{array}$

333760024

11.679

$2943 \quad 52940 \quad 10.264$

278050.120

10.078

$2780 \quad 5012010.078$

284750182

10,621

233140,661

8517

$1885+32851$

6.620

231040320

8509

238041.530

8.733

$2380 \quad 41530$

8,733

$2579 \quad 44.999$

9.588

199145600

9.787

199145600

9.737

$2890 \quad 46609$

8.468

289946.858

7,113

289946.858

$7,1 / 3$

$2896 \quad 46.776$

7,328

282743,746

8.768

$269241.702 \quad 8351$

269241.702

8351

$2.613 \quad 41.434 \quad 8.382$

$1.072 / 6.667 \quad 3.843$ Average pew day piev $1000^{\# 7.49}$
0276

0360
4.833

$6.299 \quad 1.275$ 
Table II Ster 121 werght and ofeed record - 10 Day Perivd

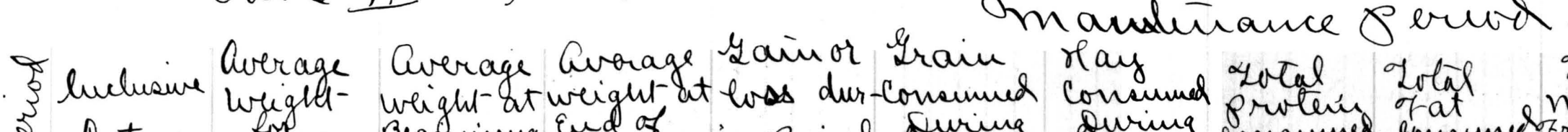

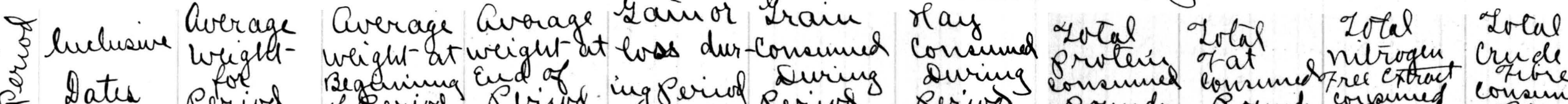

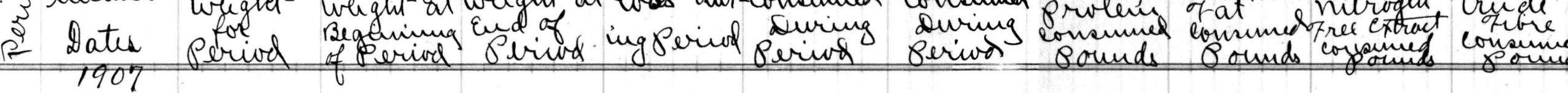

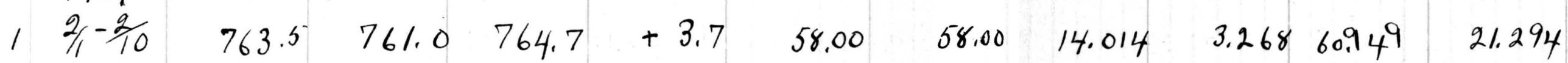

$\begin{array}{lllllllllllll}2 & 2 / 1 / 2 / 20 & 762.7 & 764.7 & 746.7 & -19.0 & 60.00 & 27.50 & 10.238 & 2.825 & 51.044 & 10.932\end{array}$

$\begin{array}{llllllllllllll}3 & 2 / 21 & -3 / 2 & 731.5 & 745.7 & 732.8 & -12.9 & 60.00 & 25.00 & 9.911 & 2.782 & 50.120 & 10.078\end{array}$

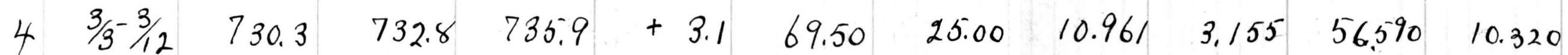

$\begin{array}{llllllllllll}5 & 3 / 3-\frac{3}{22} & 746.3 & 735.9 & 75 \% & +15.3 & 75.00 & 29.50 & 12.159 & 3.447 & 62.005 & 11.999\end{array}$

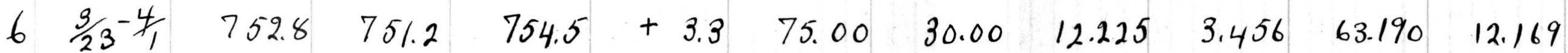

$7 \quad$ 告先 $750.4 \quad 754.5 \quad 750.4 \quad-4.1 \quad 75.00 \quad 30.00 \quad 12.225 \quad 3.456 \quad 63.190 \quad 12.169$

$8 \quad \begin{array}{lllllllllllll}12 & -4 / 21 & 757.2 & 750.4 & 762.0 & +11.6 & 72.50 & 28.95 & 11.785 & 3.337 & 60.024 & 11.679\end{array}$

$9 \quad \frac{4}{2} 2-\frac{3}{1} \quad 769.5 \quad 762.0 \quad 770.0+8.0 \quad 64.00 \quad 25.25 \quad 10.386 \quad 2.943 \quad 52.939 \quad 10.264$

$10 \quad 5 / 2-\frac{5}{11} \quad 767.5 \quad 770.0 \quad 764.0 \quad-6.0 \quad 60.00 \quad 25.00 \quad 9.911 \quad 2.780 \quad 50.120 \quad 10.078$

$11 \quad \frac{5}{12}-\frac{5}{21} \quad 767.5 \quad 764.0 \quad 775.0+11.0 \quad 60.00 \quad 25.75 \quad 10.009 \quad 2.793 \quad 50.397 \quad 10.334$

$12 \quad 5 / 22^{-\frac{3}{3}} \quad 781.5 \quad 775.0 \quad 782.5+7.5 \quad 60.00 \quad 25.00 \quad 9.483 \quad 2.732 \quad 50.182 \quad 10.621$

$13 \quad \frac{6}{2}=\frac{6}{10} \quad 781.0 \quad 782.5 \quad 779.0 \quad-3.5 \quad 49.00 \quad 19.50 \quad 7.497 \quad 2.331 \quad 40.661 \quad 8.529$

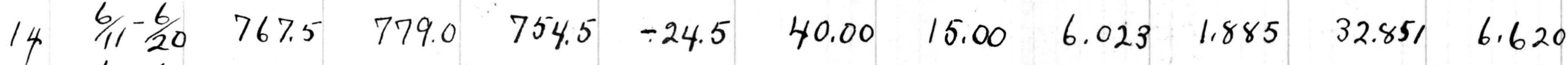

$15 \quad \frac{6}{21}-\frac{6}{30} \quad 748.5 \quad 754.5 \quad 755.7+1.2 \quad 48.50 \quad 19.50 \quad 7.442 \quad 2.310 \quad 40.320 \quad 8.509$

$16 \quad 7 / 7 / 10 \quad 7642 \quad 755.7 \quad 771.5+16.8 \quad 50.00 \quad 20.00 \quad 7.662 \quad 2.380 \quad 41.530 \quad 8.733$

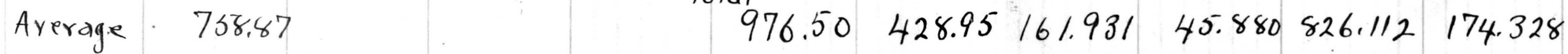

$\begin{array}{lllllllll}\text { Average per Day } & 6.103 & 2.681 & 1.012 & 0.287 & 5.163 & 1.089\end{array}$

$\begin{array}{llllllllll}\text { Average per Day per looo\# } & 8.042 & 3.533 & 1.334 & 0.378 & 6.804 & 1.435\end{array}$ 
Table IIa height and 7 eed Records. 10 Llay Periods.

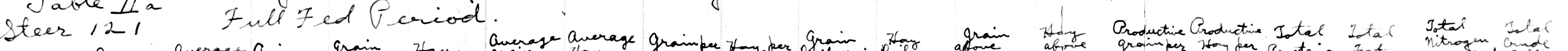

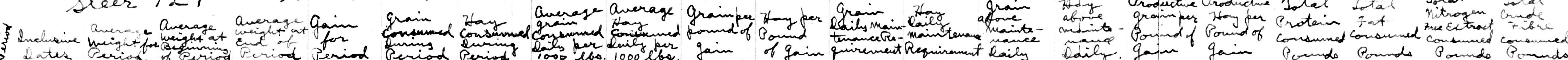

\begin{tabular}{|c|c|c|c|c|c|c|c|c|c|c|c|c|c|c|c|}
\hline $17 \quad 7 / 11-7 / 20$ & 778.0 & $771,5^{-}$ & 787.7 & 16.2 & 84.00 & 34.00 & 10.80 & 4.37 & 5.19 & $2 ! 0^{\circ}$ & 5.446 & 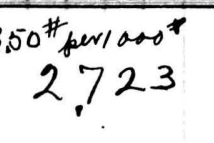 & 2954 & 0.677 & 1.82 \\
\hline $18 \quad 7 / 21-7 / 30$ & 805.9 & 787.7 & 836.0 & 48.3 & 129.00 & 51,50 & 16.01 & 6.39 & 267 & 1.07 & 5.641 & 2.820 & 7.259 & 2,330 & 50 \\
\hline $197 / 31-8 / 9$ & 858.6 & 836.0 & 879.4 & 48.4 & 153.75 & 62.00 & 17.91 & 7.22 & 3,54 & 1.43 & 6.010 & 3,005 & 9.365 & 3,195 & 216 \\
\hline $20^{8 / 10-8 / 19}$ & 913.2 & 879,4 & 932.1 & 52.7 & 160.50 & $55.25^{\circ}$ & 17.58 & 6.05 & 3.05 & 1.05 & 6.392 & 3.196 & 9.658 & 2329 & \\
\hline $218 / 20-8 / 29$ & 933.8 & 932.1 & 950.9 & 18.8 & 179.50 & 71,50 & 19.27 & 7.68 & 9,55 & $3.80^{6,4}$ & 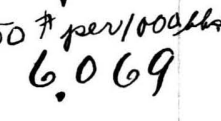 & 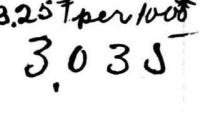 & 11.881 & 4.115 & 63 \\
\hline $28 / 3=9 / 8$ & 974.2 & 950.9 & 984.9 & 34.0 & 186.75 & $67.70^{\circ}$ & 19.17 & $6.95^{\circ}$ & 5.49 & 1.99 & 6.332 & 3.166 & 12,343 & 3,609 & 3.63 \\
\hline $39 / 9-9 / 18$ & 997.8 & 984.9 & 1030.0 & 45.1 & 197.00 & 79.00 & 19.74 & 7.92 & 4.37 & 1.75 & 6.486 & 3,243 & 13,214 & 4.657 & 2.93 \\
\hline $249 / 19-9 / 28$ & 1056.3 & 1030.0 & 1077.4 & 47.4 & 208.50 & 84.50 & 19.74 & 8.00 & 4.40 & 1.78 & 6.866 & 3,483 & 13,984 & 5.017 & 2.95 \\
\hline $25-9 / 29-10 / 8$ & 1097.4 & 1077.4 & 1111.3 & 33.9 & 221.75 & 83.00 & 20.20 & 7.56 & 654 & $2.45^{\circ}$ & 7.133 & 3.567 & 15.042 & 4.733 & 4.44 \\
\hline $2610 / 9-10 / 18$ & 1133.3 & 1111.3 & 1126.6 & 15.3 & 206.25 & 77,50 & 18.20 & 684 & 13.48 & 5.07 & 7.866 & 3.683 & 13.259 & 4.067 & 8,67 \\
\hline $27 \% \frac{19}{-10 / 28}$ & $1 / 32.7$ & 1126.6 & 1168.6 & 42.0 & 199.00 & 81,00 & 1757 & 7.15 & 4.74 & 1.93 & 7,863 & 3,681 & 12.537 & 4.419 & 299 \\
\hline $28^{10 / 29^{-11}} / 8$ & 1190.3 & 1168.6 & 1201.5 & 32.9 & 221,50 & 87,75 & 18.61 & 7.37 & 6.73 & 2,67 & 7.737 & 3.868 & 14413 & 4.907 & 4.3 \\
\hline $29 \mathrm{~m} / 8-11 / 17$ & 1211.9 & 1201.5 & 1212.4 & 10.9 & 222.75 & 88,75 & 18.38 & 7.32 & 20.44 & 8.14 & 7,877 & 3.939 & 14.398 & 4.936 & 1321 \\
\hline $30111 / 18-111 / 27$ & 1208.9 & 1212.4 & 1228.7. & 16.3 & 187.50 & 79.00 & 15.51 & 653 & 11,50 & $4,85^{-}$ & 7.858 & 3.929 & 10,892 & 3.971 & 1.68 \\
\hline $3111 / 28-12 / 7$ & 1258.1 & 1228.7 & 1266.4 & 37.7 & 188.50 & 76.75 & 14.98 & 6.10 & 5.00 & 2.04 & 8.178 & 4.089 & 10.672 & 3,586 & 2.83 \\
\hline $321 / 8-1 \% 10$ & 1261.3 & 12664 & 3 days & & 60.00 & 24.00 & 15.85 & 6,34 & & & 8.198 & 4.099 & 11,802 & 3.901 & \\
\hline
\end{tabular}
Total $2806.251103 .20^{\circ}$ Jotal Maintenancelost Period 1052.134526 .067 alaily average $18.34 \quad 7.21$

$0.4213 .241 \quad 4.10571 .65515246$ $0.48 \quad 19.755 \quad 6.137107 .110 \quad 22.495$ $\begin{array}{lllll}0.74 & 23.482 & 5.548127 .139 & 26.889\end{array}$ $0,44 \quad 23,556 \quad 5,654129292 \quad 24,478$ $2.19 \quad 30536 \quad 9.399151 .37927 .046$ $\begin{array}{lllll}1.06 & 33.937 & 9,703 / 55,855 & 21,147\end{array}$ $\begin{array}{llll}1,03 & 36,740 & 10,355 / 67,229 & 24,994\end{array}$ $106 \quad 38.69210,971176.031 \quad 27541$ $1.40 \quad 36.996 \quad 11.746181 .947 \quad 34.885$ $266 \quad 34.740 \quad 10963170.385 \quad 32.496$ $1.0534 .153 .10 .739166 .473 \quad 33.735$ $1.4937 .725 \quad 11.902184 .464 \quad 36.662$ $453 \cdot 38.01110 .992185 .670 \quad 37.082$ $2.43 \quad 32.694 \quad 10.175157 .849 \quad 32.752$ $0.9532 .472 / 0.18 / 157.73 / 31.970$ $10.24128 .81450 .043 \quad 10.022$ 476.971141 .3842340 .252439 .440 

Table IRI Steer 48 Weight and Feed Record - 10 day periods.

Surchine werage average Qnerage

gain or Grain itar Iotal Iotal Iotal Iotal $\$$ Dates for Period Begiming End of

int

\section{0 \\ 840.0 \\ 834.2}

$-5.8$

$22 / 11-\frac{2}{20}$

827.5

834.2

802.3

814.8

814.8

$-19.4$

$-9.3$

$4 \frac{8}{3}-\frac{3}{12}$

807.2805 .5

805.5

$807.2+1.7$

$53 / 13-\frac{3}{22}$

$6 \frac{3}{23}-\frac{4}{1}$

$7 \quad 4 / 2-\frac{4}{11}$

$8 \quad 4 / 12-\frac{4}{21}$

$9 \quad 4 / 22-5 / 1$

$10 \quad 5 / 2-\frac{5}{11}$

$11 \quad 5 / 2-\frac{5}{21}$

$125 / 22-\frac{5}{31}$

$136 / 1-\frac{6}{10}$

$14 \quad 6 / 11-\frac{6}{20}$

$15 \quad 6 / 2>\frac{6}{30}$ Average
$821.8817 .0826 .2+9.2$

$833.2826 .2833 .5+7.3$

$838.0833 .5841 .5+8.0$

$845.9841 .5857 .4+9.9$

$859.085 \% .4859 .5+8.1$

$856.5859 .5 \quad 859.0-0.5$

$859.0 \quad 859.0$

859.7

848.7

841.5

836.6
$809.4807 .2 \cdot 817.0+9.8$

$58.00 \quad 58.00 \quad 14.0 / 8$

$3.273-60.950$

20.396

60.00

$27.50 \quad 10.234$

2.826

$5 \% .041$

10.930

60.00

25.00

9.970

2.783

69.50

25.00

10.961

3.15

75.00

29.5

12.156

3. 443

77.50

31.25

12.666

3.572

13. 109

3.693

$\begin{array}{lll}12.782 & 3.651\end{array}$

$63.595 \quad 12.304$

$\begin{array}{lll}80.00 & 32.50 & 13.10^{9}\end{array}$

3.693

3.623

$66.5 \%$

13.158

78.50

70.50

70.00

59.00

50.00

20.00

$22.25 \quad 8.450$

$2.622 \quad 455780 \quad 9.700$ $1023.00 .445 .00 \quad 169.404 \quad 48.067 \quad 861.775 \quad 180.000$

Average per Day

Average per Day pera
6.82

8.152
$2.967 \quad 1.129$

$3.546 \quad 1.350$
$0.320 \quad 5.745 \quad 1.200$

$0.383 \quad 6.867 \quad 1.434$ 
Lable III A Ster 48 Weight and Feed Recarde - valay Reriods.

$$
\text { Full Fed Period }
$$

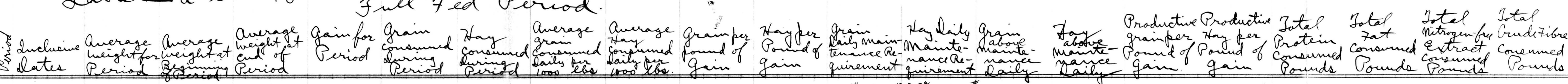

\begin{tabular}{|c|c|c|c|c|c|c|c|c|c|c|c|c|c|c|c|c|c|c|c|c|}
\hline $7 / 1-7 / 10$ & 849.9 & 846.9 & 854.0 & +7.1 & 83.00 & 34.50 & 9.77 & 4.06 & 11,69 & 4.86 & $5.94^{9}$ & 2,974 & 2.351 & 0.476 & 3,31 & 0.67 & 12.860 & 3.979 & 69.490 & 14.980 \\
\hline $7 / 11-\frac{7}{20} 0$ & 866.5 & 854.0 & 889.8 & +35.8 & 118.50 & 46,00 & 13.10 & $5.8 \%$ & 3.17 & 1.28 & 6.066 & 3.032 & 5.284 & 1.568 & 1.48 & 0.44 & 17.460 & 5,406 & 94500 & 20050 \\
\hline$\frac{7}{2} 1-\frac{7}{30}$ & 917.5 & 889.8 & 957.4 & +67.6 & 149,00 & 60.00 & $16: 24$ & 6.54 & 2,204 & .888 & 6.423 & 3.211 & 8.477 & 2.789 & 1.254 & 0.413 & 228880 & 7.100 & 123.910 & 26,170 \\
\hline $7 / 31-8 / 4$ & 992.9 & 957.4 & 1002.8 & +45.4 & 179.8 .25 & 70,00 & 17.96 & 7.05 & 3.93 & 1.54 & 6.950 & 3.475 & 10.88 & 3.525 & 2.40 & 0.78 & 27.137 & 6.409 & $1.46,715$ & 30.462 \\
\hline $8 / 10-8 / 19$ & $10 / 2.3$ & 1002.8 & 1016.5 & $f 13.7$ & 18600 & 58,50 & 18.37 & 5.78 & 13.58 & $4.27^{6.6}$ & & 3.289 & 12.021 & 2.561 & 8.77 & 1.87 & 26.881 & 4.274 & 1.47 .827 & 26.269 \\
\hline $8 / 20-\frac{8}{2} 9$ & 1012.6 & 1016.5 & 1027.7 & +11.2 & 19250 & 75.50 & 19.01 & 7.45 & 17.19 & 6.65 & 6.582 & 3.29 .1 & 12.668 & 4,259 & 11.31 & 3.80 & 32.500 & 9,848 & 1.61 .865 & 28.749 \\
\hline $8 / 30-\frac{9}{8}$ & 1054.1 & 1027.7 & 1069.6 & +41.9 & 199.50 & $79.50^{\circ}$ & 18.93 & 7.54 & 4.76 & 1.90 & 6.852 & 3,426 & 13.098 & 4.524 & 3.13 & 1,08 & 37.101 & 10.482 & 169.234 & 25.209 \\
\hline $39 / 9-9 / 18$ & 1076.6 & 1069.6 & 1099.9 & +30.3 & 280.00 & 80.00 & 18.58 & 7.43 & 6.60 & 2.64 & 6.998 & 3,499 & 13.002 & 4,501 & 4.29 & 1.49 & 37,230 & 10.513 & $169: 770$ & 25.380 \\
\hline $4^{4} 9 /, 9^{-}$ & 1118.7 & 1099.9 & 1128.8 & +28.9 & 206.736 & 85.00 & 18.49 & 7.60 & 7.16 & 2.94 & 7.272 & 3.636 & 13.408 & 4.864 & 4.64 & 1.68 & 38.563 & 11.633 & 176,004 & 27.665 \\
\hline $9 / 29^{-}$ & 1150.8 & $1 / 28.8$ & $1 / 71.5$ & +42.7 & 217,00 & 74.50 & 18.86 & 6.47 & 5.08 & 1.74 & 7.480 & 3.740 & $14 \cdot 220$ & 3.710 & 3.33 & 0.87 & 35.611 & 111406 & 176.760 & 31.666 \\
\hline $10-10 / 8$ & 1188.9 & $117 / .5$ & 1215.7 & +44.2 & 22250 & 89.00 & 18.71 & $7 \cdot 49$ & 5,03 & 2.01 & 7.728 & 3.864 & 14.522 & 5,036 & 3.29 & 1.14 & 37.982 & 11.969 & 599 & 37.159 \\
\hline $10 / 9-10 / 28$ & 1233.2 & 1215.7 & 1236.0 & +20.3 & 226.00 & 90.00 & 18.24 & 7.30 & 11.08 & 4.43 & 8.016 & 4.008 & 14.484 & 4.992 & 7.14 & 2.46 & 38.390 & 12.108 & 187.670 & 37.590 \\
\hline $28 \quad 10 / 29^{-11 / 7}$ & 1241.3 & 1236.0 & 1243.2 & +7.2 & 225.00 & 71.75 & 18,13 & 5.78 & 31,25 & 9.97 & 8.068 & 4.034 & 14.432 & 3.146 & 20.04 & 4,37 & 36.361 & 11.482 & 180.217 & 30.210 \\
\hline $911 / 188^{-11 / 7}$ & 1242.7 & 1243.2 & 1233.6 & -9.6 & 144.00 & 73.25 & 11.59 & 5.90 & & & 8.078 & 4.039 & 6.322 & 3.291 & & & 27.328 & 8.0301 & 125.79 .7 & 29.665 \\
\hline & 1210.1 & 1233.6 & $1 / 85.5$ & -48.1 & 85,00 & 53.25 & 7,02 & 4.40 & & & 7.866 & 3.933 & 0.634 & 1.397 & & & 17.623 & 4.935 & $.77,902$ & 21.084 \\
\hline $11 / 28^{-1}$ & 1181.4 & $1 / 85.5$ & 1187.5 & +2.0 & $94 \times 25$ & 59,00 & 7.98 & 4.99 & 47.15 & 29.50 & 7.679 & 3.839 & 1.751 & 2,061 & 8.76 & 10.31 & 19.010 & 5.425 & $-86: 226$ & 23.338 \\
\hline & 1199.2 & 1187.5 & 1195,0 & +7.5 & 120.75 & 63.00 & 10.12 & 5.28 & 16.11 & 8.40 & 7.756 & 3.878 & 4.324 & 1.976 & 5.77 & 2.63 & 22.619 & 6.7501 & 105.967. & 25.410 \\
\hline & 1198.6 & 11950 & 1206.8 & +11.8 & 106.50 & 80.50 & 8.886 & 6.716 & 91026 & 6.822 & 7.791 & 3.895 & 2.859 & 4.155 & 2.423 & 3,521 & 23.395 & 6.355 & 102,384 & 31.321 \\
\hline$/ 2$ & 1220.9 & 1206.8 & 1231.4 & +24.6 & 139.25 & 78.00 & 11.405 & 6.388 & 5.661 & 3.171 & 7.936 & 3.968 & 5.989 & 3.832 & 2.435 & 1.557 & 26.024 & 7.908 & 123.586 & 32.659 \\
\hline 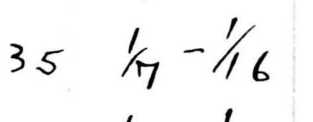 & 1242.6 & 1231.4 & 1263.1 & +31.7 & 132.75 & 60.00 & 10.683 & 4.828 & 4.188 & 1.893 & 8.077 & 4.038 & 5.198 & 1.962 & 1.640 & 0.619 & 22.854 & 7.531 & 112,921 & $26 \cdot 029$ \\
\hline $1 / 17 / 26$ & 1271.6 & 1263.1 & 1268.4 & +5.3 & 154.25 & 63.00 & 12.131 & 4.955 & 29.10 & 11.887 & 8.265 & 4.132 & 7.160 & 2.168 & 13.509 & 41092 & 24.811 & 11.757 & 125,223 & 27,64 \\
\hline
\end{tabular}


Lable III a cont. Ster 48.

weight aind Freed Records - 10 Day Perivels ofull Fed juird.

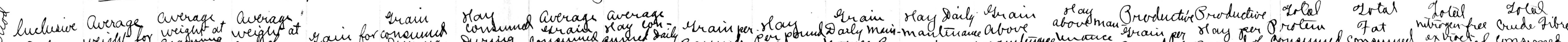

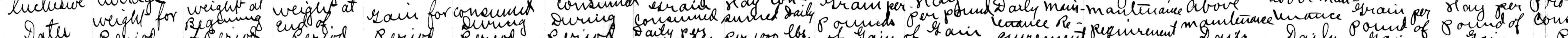

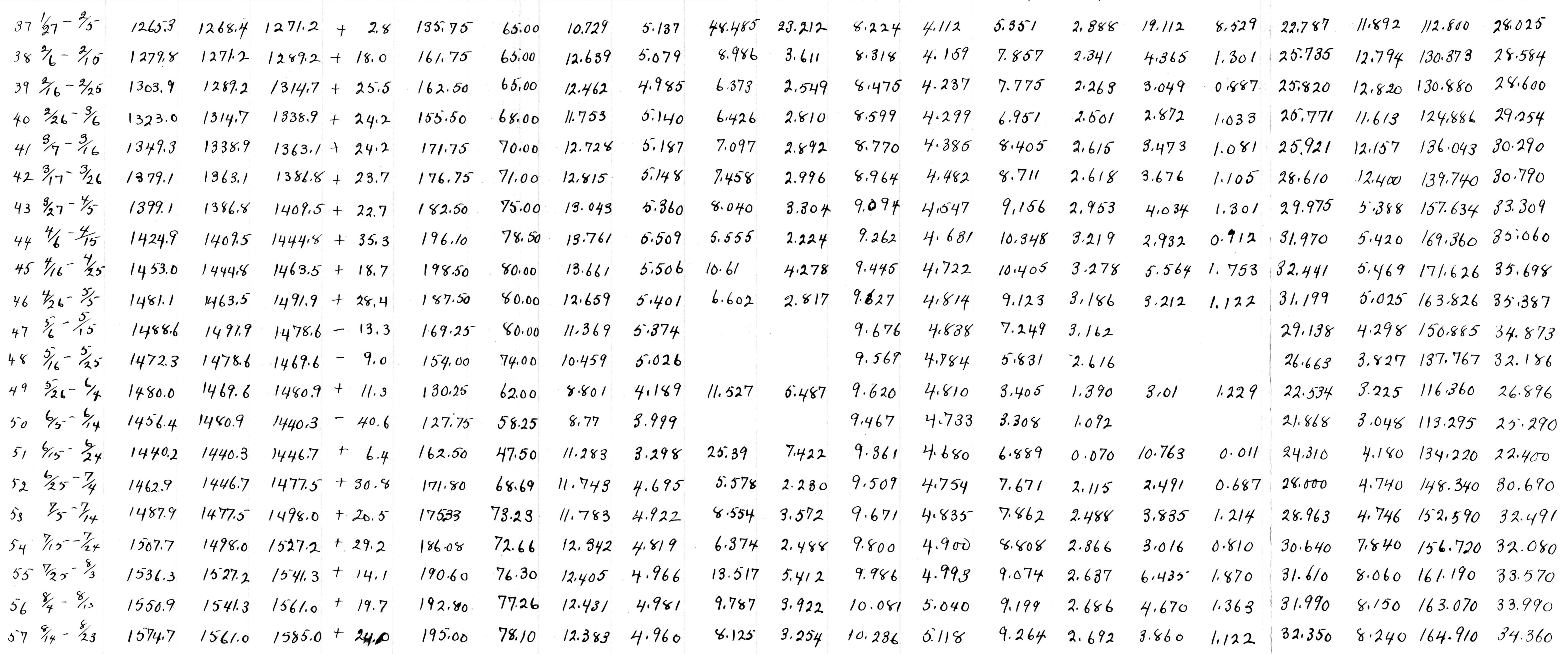




\section{Bable III a Cout. Sterr48}

Weight and 7reed Records - 10 Vhay Periods

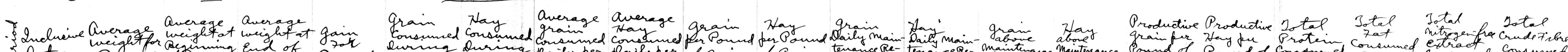

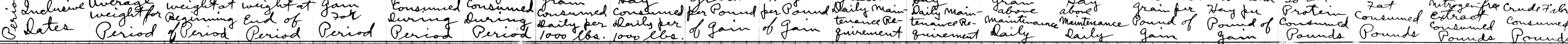

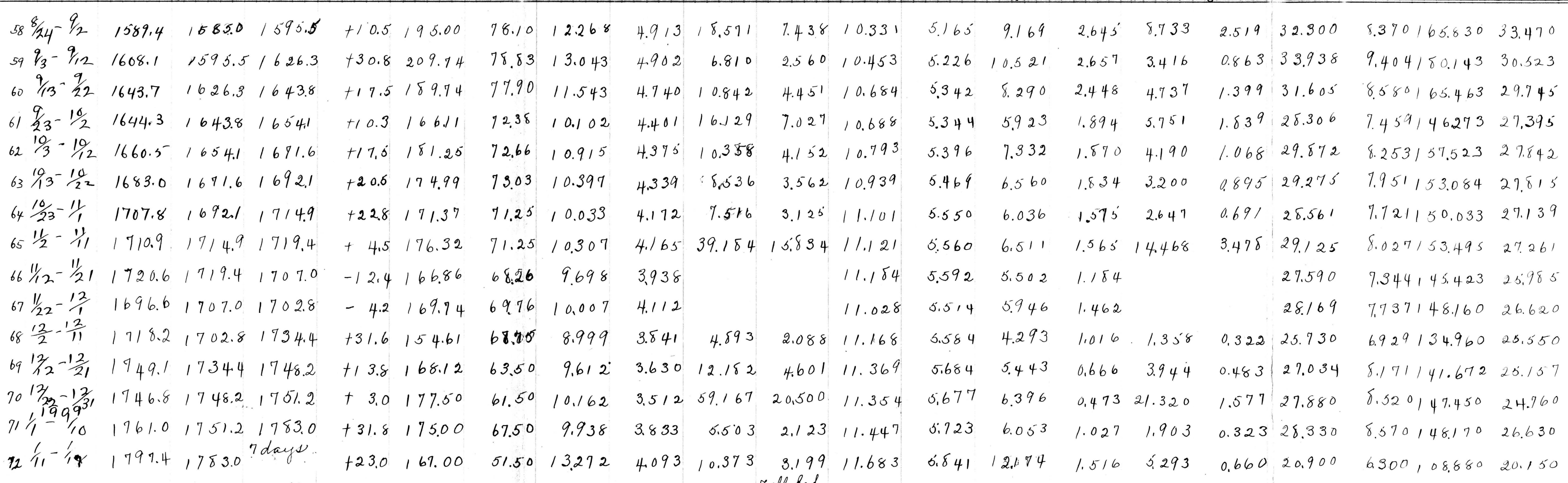

Jatal $\$ 602.063992 .66$ Iotal maintenume, cost pelicod 5120.0312559 .887 Dailyanerage $16.93 \quad 7.01$ 
Jable IV Ster 18 Feed Analysis-10 Day Peivods

Ratio of grain: 8 com to / linseed.

\$2ncluain Grain consumed Consumed Protein 7 at in Mitrogentrue Fibre

Pounds Ponsunds Ponseed Pounds Tunseed Finseed

$\begin{array}{lllll}\text { Percent. } & \longrightarrow & 100 \% & 3.624 \% \quad 72.12 \% & 1.9 .36 \%\end{array}$

$12 / 1-2 / 10 \quad 58.0051 .5+56$

$2 \%-2 / 200.00 \quad 53.333$

$3 \quad 2 / 21-\frac{3}{2}$

$43 / 3-3 / 12$

$53 / 13-\frac{3}{22}$

$63 / 23-4 / 1$

$7 / / 2-4 / 11$

$8 \quad 4 / 12-4 / 21$

$94 / 22-5$

$10 \frac{5}{2}-5 / 1$

$11 \frac{5 / 12}{\frac{5}{22}-\frac{5}{21}}$

$12\left\{\begin{array}{c}5 / 26-5 / 31 \\ 1\end{array}\right\}$

$60.00 \quad 53.333$

69.5061 .778

$75.00 \quad 66.667$

$75.00 \quad 66.667$

$75.00 \quad 66.667$

$72.50 \quad 64.444$

$64.00 \quad 56.889$

$60.00 \quad 5.3 .333$

$60.00 \quad 53.333$

60.00

53.333

$136 / 1-\frac{6}{10}$

$49.00 \quad 43.556$

$146 / 11-\frac{6}{20}$

15 b -6

$167-7$

$177-7$

$187-20$

$\frac{7}{21}-130$

$40.00 \quad 35.556$

$48.50 \quad 43.111$

50.0044 .444

50.0044 .444

54.0048 .000

79

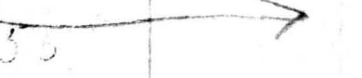

$\begin{array}{lllll}4.176 & 1.870 & 37.180 & 0.998\end{array}$

$\begin{array}{lllll}4.320 & 1.933 & 38.463 & 1.034\end{array}$

4.320

5.004

5.400

5.400

5.400

5.220

4.608

4.320

4.320

$\begin{array}{llll}1.935 & 38.463 & 1.034\end{array}$

$2.241 \quad 44.550 \quad 1.196$

$2.418 \quad 48.080 \quad 1.291$

$2.418 \quad 48.080 \quad / .291$

$2.418 \quad 48.080 \quad 1.291$

$2.338 \quad 46.477 \quad 1.248$

$2.064 \quad 41.028 \quad 1.101$

$1.933 \quad 38.463 \quad 1.034$

$1.933 \quad 38.463 \quad 1.034$

$\begin{array}{lllll}4.320 & 1.933 \quad 38.463 \quad 1.034\end{array}$

6.44434

6.1444

6.667

6.667

7.722

8.333

8.333

8.333

8.056

7.111

6.667

6.667

\section{2,314}

2.893

2893

2.797

3,528$$
1580
$$
$2.880 \quad 1.290 \quad 25.643 \quad 0.688$

$\begin{array}{llll}3.492 & 1.562 & 31.090 & 0.835\end{array}$

$\begin{array}{llll}3.600 \quad 1.612 & 32.053 & 0.860\end{array}$

$3.600 \quad 1.612 \quad 32.053 \quad 0.860$

$\begin{array}{lllll}3.888 & 1.741 \quad 34.615 & 0.928\end{array}$ $8.006 \% \quad 2.322 \% \quad 71.57 \% \quad 1.825 \%$

$19 \frac{7}{31}-8 / 9 \quad 55.00 \quad 48.889 \quad 3.918 \quad 1.135 \quad 34.990 \quad 0.892$

$20 \frac{8}{10}-8 / 9 \quad 55.00 \quad 48.889$

$\begin{array}{lllll}3.918_{(87)^{1.135}} 34990 & 0.892\end{array}$
6.667

$6.1 / 1+2.122$

0.419

2.420

5.444

4.444

5.389

5.556

5.556

6.000

$6.1 / 1$

$0.339 \quad 1.956$

$0.377 \quad 2.178$

$0.384 \quad 2.218$
237.

$2.3 / 4$

2.680

2.893

2,469

$2.3 / 4$$$
\text { . }
$$

$6.290 \%$

$36.30 \%$

$7.607 \%$

0.405

2.339

0.490

0.419

2.420

0.507

0.419

0.486

0.524

0.524

$0.524 \quad 3.025$

0.507

0.447

2.924

0.419

2.420

$0.4 \div 9$

2.42

20

Ftay Protion Fat in Extrogenfree Crude 7 ibre

\begin{tabular}{ll|l|l|l|}
$13.106 \%$ & $1.712 \%$ & $36.949 \%$ & $34.148 \%$
\end{tabular}

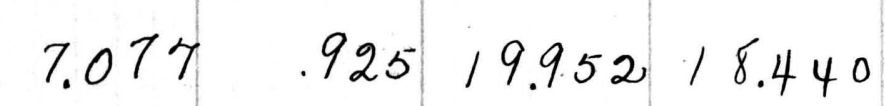
$\begin{array}{lllllll}54.00 & 1.00 & 3.604 & .471 & 10.161 & 9.391\end{array}$

$\begin{array}{llllll}2500 & 3.277 & .428 & 9.237 & 8.537\end{array}$

$\begin{array}{lllll}3.274 & .428 & 9.237 & 8.537\end{array}$

$3.866 \quad .50510 .900 \quad 10.074$

$3.932 \quad .514 / 1.085 / 0.244$

$3.932 \quad .514 / 1.085 / 0.244$

$3.768 \quad .492 / 0.623 \quad 9.818$

$\begin{array}{llll}3.309 \quad .432 & 9.330 \quad 8.622\end{array}$

$\begin{array}{llll}3.247 & .428 & 9.237 & 8.537\end{array}$

$\begin{array}{llll}3.277 & .428 & 9.237 & 5537\end{array}$

$\begin{array}{lllll}0.983 & 0.128 & 2.771 & 2.561\end{array}$

0.507 Percent. $10.663 \%$ 2.097\% $37.30 \% \quad 37.253 \%$ (17.50

$1.890 \quad 0.942 \quad 1.976$

$0.414 \cdot 19.50$

\begin{tabular}{ll|l|l|}
1.866 & 0.367 & 6.528 & 6.519
\end{tabular}

$2.079 \quad 0.409 \quad 7.274 \quad 7.260$

$0.280 \quad 1.613$

0.338

0.410

15.00

1.600

$0.315 \quad 5.595 \quad 5.594$

$0.349 \quad 2.017$

0.423

20.00

2.079

$0.409 \quad 7.274 \quad 7.264$

2.13

0.456

22.00

2.34

0.465

22,50

2.399

$\begin{array}{lll}0.384 & 2.21 \delta\end{array}$

0.455

22.50

2.399
$0.472 \quad 8.392 \quad 8.380$

$\begin{array}{lll}0.472 & 8.392 \quad 8.380\end{array}$ 


\section{Sable IV Steer 18 \\ Feed Analysis - 10 day Periods.}

cont.

Pratim Zat Mitrogenfre Crude 7 ibre

Linseed Protein Fat in Mitrogenfrer Crude

Thay Protin Fat in Nitrogenfree Aude 7 ibre

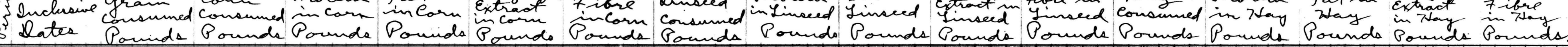

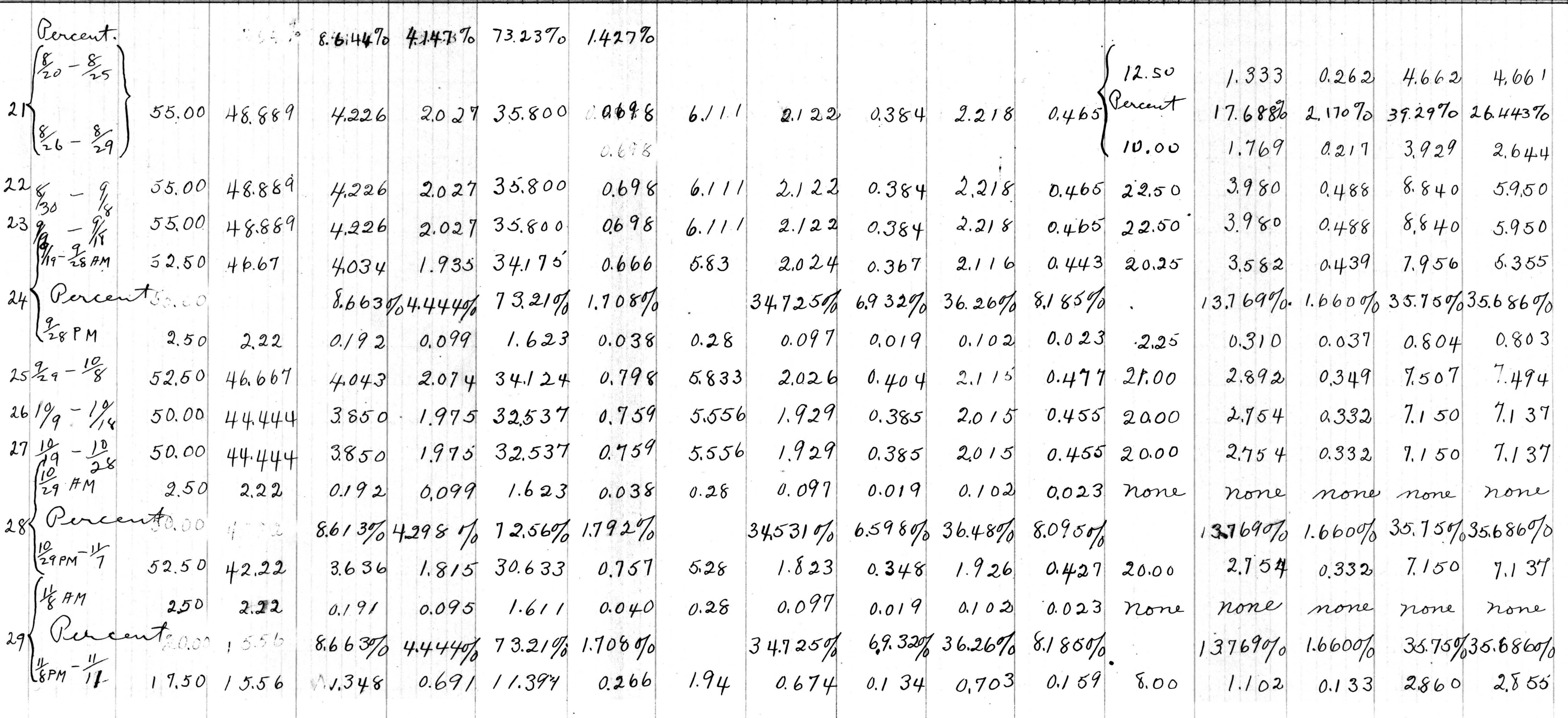


Jable V Sterr 121 Feed Analyaie - 10 dlay Periods (Maintenance Period).

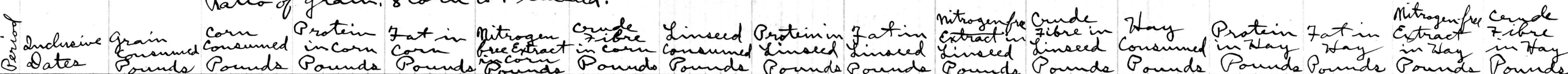

Mitrogenfres Ceryde

$\begin{array}{lllll}\text { Percent. } & 8.100 \% & 3.624 \% & 72.12 \% & 1.936 \%\end{array}$

$12 / 1-2 / 10$

$22 / 1,-2 / 20$

$3 \frac{2}{21}-\frac{3}{2}$

$+3 / 3-3 / 12$

$53 / 13-3 / 22$

$63 / 4=4 / 2$

$7 \frac{23}{4}-4 / 1$

$8 \frac{4}{4}-4 / 11$

$4 / 12-4 / 21$

$94 / 22-5 / 1$

$10 \frac{5}{2}-5 / 11$

$12\left\{\begin{array}{l}11 \frac{5}{22}-\frac{5}{\frac{5}{21}} \\ \frac{5}{26}-\frac{5}{31}\end{array}\right\} 60$

$136 / 1-6 / 10$

$14 \frac{6}{11}-\frac{6}{20}$

$15 \frac{11}{6}-20$

$16 \frac{6}{2 !}-\frac{6}{30}$

$\begin{array}{llllll}58 . & 51.556 \quad 4.176 .1 .870 & 37.180 & 0.998\end{array}$

6o. 53333

60. 53,333

69.561 .778

75. 66.664

75. 66.667

75.66 .667

$72.6 \quad 64.444$

64. 56.889

bo. $\quad 53.333$

60. $\quad 53.333$

60.

49.43 .556

40. 35.556

$48.5^{\prime} \quad 43.111$

50. 44.444 $\begin{array}{lllll}4.320 & 1.935 & 38.463 & 1.034\end{array}$

$\begin{array}{lllll}4.320 & 1.935 & 38.463 & 1.034\end{array}$

$5.004 \quad 2.241 \quad 44.550 \quad 1.196$

$5.400 \quad 2.418 \quad 48.080$

5.400

5.400

5.220

4,608

4.320

4.320

$4 \cdot 320$

$4.320 \quad 1.933$

3.528

2,880

3.492

3.600

$1.933 \quad 38.463 \quad 1.034$

$\sqrt{3}$ \\ 38}

$1.290 \quad 25.643 \quad 0.688$

$1.562 \quad 31.090 \quad 0.835$

1.61232 .053 $\begin{array}{llllll}34.7 / 3 \% & 6.290 \% & 36.30 \% & 7.607 \%\end{array}$

$8.4631 .034 \quad 6.667$ 6.444

6.667

6.667

7.222

8.333

8.333

8.333

8.056

7.111

6.667

6.667

\subsection{7}

2.314

2.314

2.680

2.893

2.893

2.893

$.2 .79 \%$

2.46

2.314

2.314

2.314

890

$4.444 \quad 1.543$

$5.389 \cdot 1.871$

$5.556 \quad 1.929$
0.40 .5

0.419

$0.4 / 9$

0.486

0.524

0.52

0.507

0.44

0.419

0.419

0.419

0.342

0.280

0.339

0.349
$13.106 \% \quad 1.712 \% \quad 36.949 \% \quad 34.148 \%$

$\begin{array}{lllllllll}2.420 & 0.504 & 27.50 & 3.604 & 0.471 & 10.161 & 9.391\end{array}$

$\begin{array}{lllllll}2.420 & 0.507 & 25.00 & 3.274 & 0.428 & 9.237 & 8.537\end{array}$

$\begin{array}{llllllll}2.803 & 0.587 & 25,00 & 3.247 & 0428 & 9.237 & 8.537\end{array}$

$\begin{array}{lllll}29.50 & 3.866 & 0.505 / 0.900 \quad 10.074\end{array}$

$\begin{array}{lllll}30.00 & 3.932 & 0.5 / 4 & 11.085 & 10.244\end{array}$

$35.00 \quad 3.932 \quad 0.51411 .085 / 0.244$

$\begin{array}{lllll}2.5 .75 & 3.768 & 0.492 & 10.623 & 9.818\end{array}$

$2.924 \quad 0.613$

$25.215 \quad 3.309 \quad 0.432 \quad 9.329 \quad 8.622$

$\begin{array}{lllllll}2.420 & 0.507 & 2.5 .00 & 3.277 & 0.428 & 9.237 & 8.537\end{array}$

$\begin{array}{lllllll}2.420 & 0.507 & 25.75 & 3.375 & 0.441 & 9.514 & 8.793\end{array}$

2.420

$0.507\left\{\begin{array}{c|c|c|c|c}7.50 & 0.983 & 0.013 & 2.771 & 2.561 \\ \text { Percent } & 10.663 \% & 2.097 \% & 37.30 \% & 37.253 \% \\ 17.50 & 1.866 & 0.367 & 6.528 & 6.519\end{array}\right.$

$\begin{array}{llllllll}1.976 & 0.414 & 19.50 & 2.079 & 0.409 & 7.274 & 7.272\end{array}$

$\begin{array}{lllllll}1.613 & 0.338 & 15.00 & 1.600 & 0.315 & 5.595 & 5.594\end{array}$

$\begin{array}{lllllll}1.966 & 0.410 & 19.50 & 2.079 & 0.409 & 7.274 & 7.264\end{array}$

$2,017 \quad 0.423$

20.00

2.133

0.4197 .460

7.450 


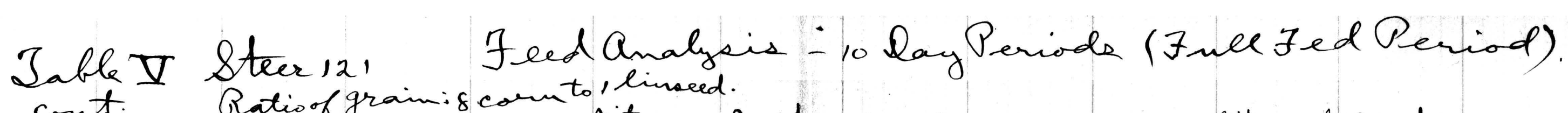

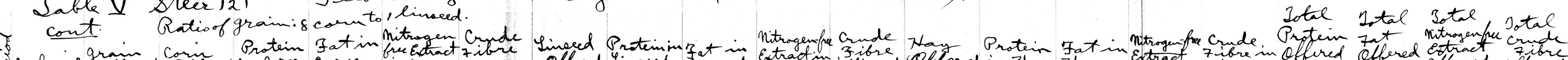

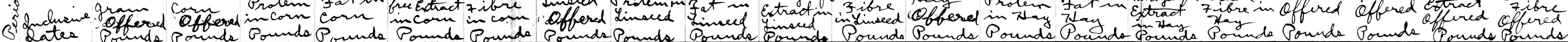

\begin{tabular}{|c|c|c|c|c|c|c|c|c|c|c|c|c|c|c|c|c|c|c|c|c|}
\hline & 86. & 76.444 & 6.192 & 2.770 & $5.13 \%$ & 1.480 & 9.556 & 3.317 & 601 & 4.69 & 0.727 & 35,00 & 3.732 & 0.7 .34 & 3.055 & 13.039 & 13.241 & 4.105 & 5 & 15.2 \\
\hline $18 \frac{7}{21}-\frac{7}{30}$ & 129. & $\begin{array}{l}11 \\
\text { Bercent. }\end{array}$ & $\begin{array}{r}9.288 \\
8.006 \%\end{array}$ & $\begin{array}{r}4.155 \\
2.322 \%\end{array}$ & $\begin{array}{l}82.698 \\
91.87 \%\end{array}$ & $\begin{array}{l}2.220 \\
1.825 \%\end{array}$ & 14.383 & 4,975 & 0.902 & 5.203 & 1.090 & 51.50 & 5.492 & $\begin{array}{l}1.080 \\
1.00\end{array}$ & 19.209 & 19.185 & $19.7^{\prime} 55$ & 6.137 & 107.110 & 22.495 \\
\hline & 153.75 & 5136.667 & 10.941 & 3.173 & $878 \% 2$ & 2.494 & 17.083 & 5,930 & 1.075 & 6.201 & 1.299 & 62.00 & 6.611 & 1.300 & 23126 & 23.096 & 23.482 & $5.548^{\prime} 1$ & 124.139 & 26.889 \\
\hline $20 \% \frac{8}{10}$ & 162.5 & $\begin{array}{l}1.44 .444 \\
\text { Rercent. }\end{array}$ & $\begin{array}{l}11.564 \\
8.644 \%\end{array}$ & $\begin{array}{r}3.3541 \\
4.147 \%\end{array}$ & $\begin{array}{l}103.379 \\
73.23 \%\end{array}$ & $\begin{array}{l}2.636 \\
1.427 \%\end{array}$ & 18.056 & 6.268 & 1.136 & 6.554 & 1.374 & 65.00 & 6.931 & 1.363 & 24.245 & 24.213 & 24.763 & 5.853 & 134.178 & 28,223 \\
\hline 1$)$ & 181. & 160.88 .9 & 13.907 & 6.6721 & 17.819 & 2.296 & 20.111 & 6.981 & 1.265 & 7.300 & 1. & $\begin{array}{r}41.00 \\
\text { Percent } \\
31.50\end{array}$ & $\begin{array}{r}4.372 \\
17.688 \% \\
5.572\end{array}$ & $\begin{array}{r}0.860 \\
2.170 \% \\
0.684\end{array}$ & $\begin{array}{l}15.292 \\
39.29 \% \\
12374\end{array}$ & $\begin{array}{r}15.273 \\
26.443 \% \\
8.330\end{array}$ & 30.832 & 9.4811 & 152.788 & 27.429 \\
\hline & 200. & 177.778 & 15.367 & 7.3721 & 30.187 & 2.537 & 22.222 & 7.714 & 1.397 & 8.067 & 1.690 & 80.00 & 14.150 & 1.736 & 31.430 & 21.153 & 37.231 & 10.5051 & 169.684 & 25,380 \\
\hline & 200. & 177.778 & 1.5 .367 & 7.3721 & 30.187 & 2.537 & 22.222 & 7.714 & 1,397 & 8.067 & 1.690 & 80.00 & 14.150 & 1.736 & 31.430 & 21.15 .3 & 37.231 & 10.5051 & 84 & 25.380 \\
\hline & & 178.889 & 15.463 & 7.419 & 31.000 & 2.553 & 22361 & 7.762 & 1.407 & 8.117 & 1.701 & 76.50 & 13.530 & 1.660 & 29.057 & 20.228 & & & & \\
\hline & 211.75 & & $8.663 \%$ & $4.444 \%$ & $73.21 \%$ & $1.708 \%$ & & $34.725 \%$ & $6.932 \%$ & $36.26 \%$ & $8.185 \%$ & & $13.769 \%$ & $1.660 \%$ & $35.75 \%$ & $36.686 \%$ & 39.139 & 11.1231 & 178.469 & 27.770 \\
\hline & & 9.333 & 0.0889 & $410^{\prime}$ & 6.833 & 0.159 & 1.167 & 0.405 & 0.081 & 0.423 & 0.096 & .8 .50 & 1.170 & 0.141 & 3.039 & 3.033 & & & & $\therefore$ \\
\hline & 221.75 & 197.111 & 17.076 & 8.760, & 44.305 & 3.367 & 24.639 & 8,556 & 1.708 & 8.9 .34 & 2.017 & 89.00 & 12.253 & 1.474 & 31.817 & 31.760 & 37.885 & 11.9451 & 155.056 & 37.144 \\
\hline $6 \frac{9}{109} 9-\frac{10}{16}$ & 225. & 200 & 17.326 & 8.8881 & 46.420 & 3.416 & 25,000 & 8.681 & 1.733 & 9.065 & 2.046 & 90.00 & 12.391 & 1.494 & 32.175 & 32.118 & 38.398 & 12.1151 & 187.660 & 37.580 \\
\hline & 199. & 176.889 & 15.323 & 7.8611 & 29.500 & 3021 & 22.111 & 7.678 & 1 's 33 & 8.017 & 1.810 & 81.00 & 11.152 & 1,345 & 28.956 & 28.904 & 34.153 & 10.739 & 166.473 & 33.735 \\
\hline $28 \frac{10}{\frac{10}{9}}-\frac{28}{7}$ & 225. & 200. & 17.326 & 8.8881 & 46.420 & 3.416 & 25,000 & 8.681 & 1.733 & 9.065 & 2.046 & 90,00 & 12:391 & 1.494 & 32.175 & 32.118 & 38.398 & 12,1151 & 187.660 & 37,580 \\
\hline 2929 & 225. & 200 & 17.326 & 8.8881 & 46.420 & 3.416 & 25,000 & 8.681 & 1.733 & 9.065 & 2046 & 90.00 & 12.391 & 1.494 & 32.175 & 32.118 & 38.398 & 12.115 & 187.660 & 37.580 \\
\hline $30 \frac{8}{118}$ & 209. & 185.788 & 16.094 & 8.2561 & 36.008 & 3.173 & 23222 & 8.064 & 1.610 & 8.420 & 1.901 & 83.00 & 11.428 & 1.378 & 29.670 & 29.619 & 35.586 & 11.2441 & 174.098 & 34.693 \\
\hline & 200. & 177.778 & 15.400 & 7.9001 & 30.151 & 3.036 & 22.222 & 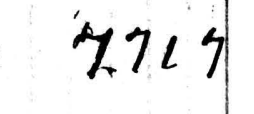 & 1.540 & 8.058 & 1.819 & 80.00 & 11.015 & 1.328 & 28.600 & 28.549 & 34.132 & 10.768 & 166.809 & 33,404 \\
\hline $32 \frac{20}{12 / 8}-$ & 60. & 53.334 & 4.620 & $2.370^{\circ}$ & 39.046 & .911 & 6.667 & 2.316 & 0.046 & 2.417 & 0.546 & 24.00 & 3.305 & 0.398 & 8.580 & $8.565^{\prime}$ & 10.241 & 2.814 & 50.043 & 10022 \\
\hline
\end{tabular}


Refused Feed Analyoir-10 Dlay Periods.

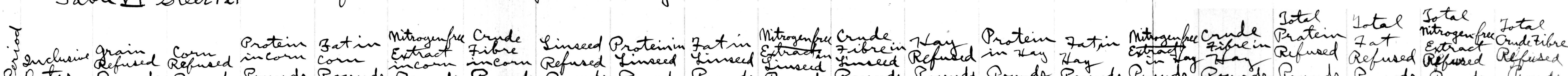

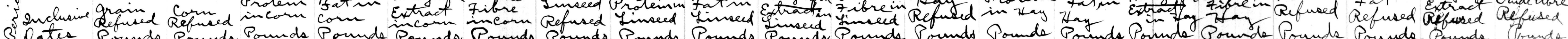

\section{No feed ware refused until period 20.}

18. No refusedgrainwas analyged previous to tan.7,1908, it being fed back eachtime. Sofor the refused grain

recorded here and in Iable VIII beforethat date, the analyses of the corn and hinsed fed war nued in the calculation.

191907 Percent $8.006 \%$ 2.322\% $71.57 \%$ 1.825\% Perlent. 34.713\% 6.290\% 36.30\% $2.607 \%$ Per cent. 10.138\% $1.475 \% \quad 36.23 \% 37.905 \%$

\begin{tabular}{ll|l|l|l|l|l|l|l|l|l|l|l|l|l|l|l|l|l|l|l|l|l|l|}
$20 \% 10$ & $-\frac{8}{19}$ & 2.00 & 1.778 & 0.142 & 0.041 & 1.273 & 0.032 & 0.222 & 0.077 & 0.014 & 0.081 & 0.017 & 9.75 & 0.988 & 0.144 & 3.532 & 3.696 & 1.207 & 0.199 & 4.886 & 3.745 \\
\hline
\end{tabular}

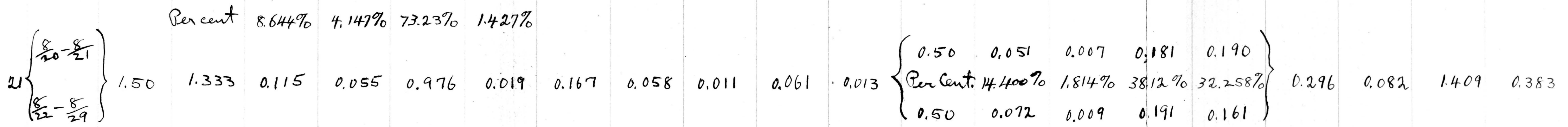

\begin{tabular}{lllllllllllll|l|l|l|l|l|l|l|l}
$22 \frac{8}{3} 0-9 / 8$ & 13.25 & 11.778 & 1.019 & 0.487 & 8.625 & 0.168 & 1.472 & 0.511 & 0.093 & 0.534 & 0.112 & 12.25 & 1.764 & 0.222 & 4.670 & 3.953 & 3.294 & 0.802 & 13.829 & 4.233
\end{tabular}

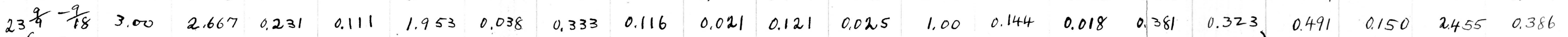

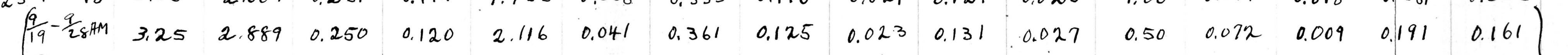

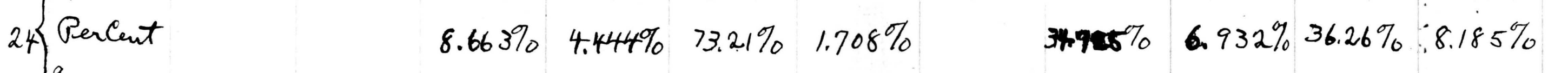

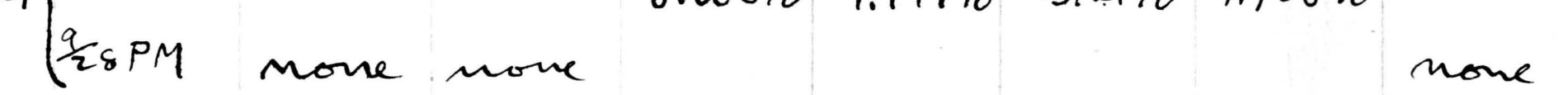

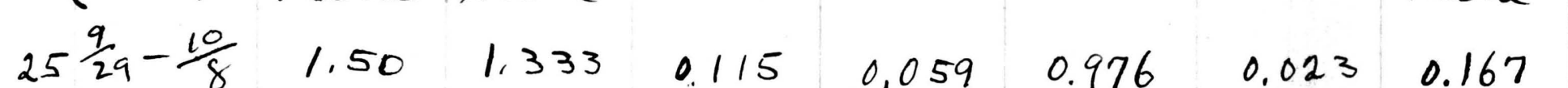

$\begin{array}{lllllllllllll}10 & 10 & 0.061 & 0.014\end{array}$

none $11.93 \% \% \quad 2.132 \% 34.54 \% 37.025 \%\} 0$

$0.447 \quad 0.152 \quad 2.438 \quad 0.229$

\begin{tabular}{ll|l|l|l|l|l|l|l|l|l|l|l|l}
26 & $\frac{10}{9}-\frac{10}{18}$ & 18.75 & 16.667 & 1.444 & 0.741 & 12.202 & 0.285 & 2.083 & 0.723 & 0.144 & 0.755 & 0.171
\end{tabular}

$\begin{array}{llllllllll}6.00 & 0.716 & 0.128 & 2.072 & 2.222 & 0.889 & 0.199 & 3.109 & 2.259\end{array}$

$27 \frac{10}{19}-\frac{10}{28}$ none

\begin{tabular}{llllll|l|l|l|l|l|l|l|}
$28 \frac{10}{29}$ & $-\frac{11}{7}$ & 3.50 & 3.111 & 0.270 & 0.138 & 2.278 & 0.053 & 0.389 & 0.135 & 0.027 & 0.141 & 0.032
\end{tabular}

$\begin{array}{lllllll}12.50 & 1.491 & 0.267 & 4.318 & 4.628\end{array}$

none

$29 \frac{11}{8}-\frac{11}{17} \quad 2.25$

\begin{tabular}{l|l|l|l|l|l|l|l|l|l|}
0.173 & 0.089 & 1.464 & 0.034 & 0.250 & 0.087 & 0.017 & 0.091 & 0.020 \\
\hline
\end{tabular}

2.25

$\begin{array}{lllll}0.268 & 0.048 & 0.777 & 8.333\end{array}$

$\begin{array}{lllll}3.658 & 1.152 & 17.275 & 5.084\end{array}$

\begin{tabular}{ll|l|l|l|l|l|l|l|l|l|l|l|}
30 & $\frac{11}{18}-\frac{11}{27}$ & 21.50 & 19.111 & 1.656 & 0.849 & 13.991 & 0.325 & 2.389 & 0.830 & 0.166 & 0.866 & 0.196 \\
\hline
\end{tabular}

$\begin{array}{rrrrr}1.25 & 1.144 \% & 1.350 \% & 34.80 \% & 35.509 \%\end{array}$

$31 \frac{11}{28}-\frac{12}{7}$

$32 \frac{12}{8}=\frac{12}{10}$

11.50
nove

$\begin{array}{llllll}0.222 & 0.886 & 0.454 & 7.484 & 0.175\end{array}$

\begin{tabular}{ll|l|l|l|l|l|}
1.278 & 0.444 & 0.089 & 0.463 & 0.105
\end{tabular}

$\begin{array}{llllll}4.00 & 0.406 & 0.054 & 1.392 & 1.420\end{array}$

$\begin{array}{llllll}3.25 & 0.330 & 0.044 & 1.131 & 1.154\end{array}$

none

mone none. none none 
Table VII Steer 48 Feed Analysiz - 10 llay Periods (Maintenance Beriod).

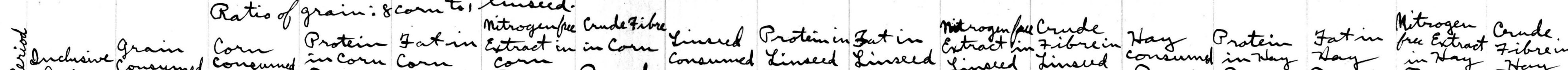

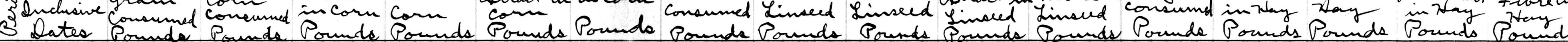

\section{Percent. \\ $\begin{array}{llll}8.100 \% & 3.624 \% & 72.120 \% \quad 1.936 \%\end{array}$}

$\begin{array}{llllllll}12 & 2 / 10 & 58.00 & 51.56 & 4.176 & 1.870 & 37.18 & 0.10\end{array}$

$\begin{array}{lllllllll}2 & 2 & 2 & 60.00 & 53.33 & 4.320 & 1.935 & 38.46 & 1.03\end{array}$

$311-\frac{20}{20}$

$32 / 2-3 / 2$

$4 \frac{321}{3}-\frac{3}{12}$

60.00 69.50

53.33

$53 / 3-3 / 275,00$

$63^{3} / 3^{2}-47.50$

$7 \cdot \frac{4}{2}-\frac{4}{11} 80.00$

$8 \frac{4}{12}-\frac{4}{21}$

9 特- $\frac{21}{5}$

$10 \frac{5}{2}^{2}-\frac{5}{6}$

$12\left\{\begin{array}{l}\frac{5}{12}-\frac{5}{2}-\frac{5}{25} \\ \frac{5}{26}-\frac{5}{31}\end{array}\right\}$

$136,1,6$

$146 / 1-\frac{6}{20}$

$15 \frac{6}{21}-\frac{6}{30}$

.59 .00

50.00

55.00 $\begin{array}{llll}61.78 & 5.004 & 2.24 .1 & 44.55\end{array}$

$\begin{array}{llll}66.67 & 5.400 & 2.4 ! 8 & 48.08\end{array}$

$68.89 \quad 5.58$

$71.11 \quad 5.76$

$71.11 \quad 5.76$

$41.11 \quad 5.76$

$69.98 \quad 5.65$

$62.67 \quad 5.08$

$62.22 \quad 5.04$

$52.44 \quad 4.25$

$44.44 \quad 3.60$

$48.89 \quad 3.96$

$2.75^{\circ} \quad 45.20$

$1.611 \quad 32.05$

$1.772 \quad 35.26$ \begin{tabular}{l|l|l}
2.256 & $44.87 \quad 1.20$
\end{tabular}
$34.713 \% \quad 6.290 \% \quad 36.30 \% \quad 7.607 \%$ $6.44 \quad 2.24$ $6,67 \quad 2,31$ $\begin{array}{ll}6.67 & 2.31\end{array}$ $7.72 \quad 2.68$ $8.33 \quad 2.89$ $8,61 \quad 2.99$ $8.89 \quad 3.09$ $8.89 \quad 3.09$ $8.89 \quad 3.09$ $8.72 \quad 303$ $7.83 \quad 2.72$

7.78

2.70

0.49

2.82

$\begin{array}{lllll}1.901 & 37.82 & 1.02 & 6.56 & 2.28\end{array}$
0.86

0.95
$5.56 \quad 1.93$

6.11

2,12
$0.41 \quad 2.38$

0.35

0.38
$13.106 \% \quad 1.712 \% \quad 36.949 \% \quad 34.148 \%$ $\begin{array}{llllllll}0.49 & 58.00 & 7.602 & 0.993 & 21.430 & 19.806\end{array}$ $\begin{array}{llllllll}0.51 & 27.50 & 3.604 & 0.471 & 10.161 & 9.390\end{array}$ $\begin{array}{lllllll}0.51 & 25.00 & 3.277 & 0.428 & 9.237 & 8.537\end{array}$ $\begin{array}{lllllll}0.59 & 25.00 & 3.277 & 0.428 & 9.237 & 8.537\end{array}$ $\begin{array}{llllllll}0.63 & 29.50 & 3.866 & 0.505 & 0.900 & 10.074\end{array}$ $\begin{array}{llllllll}0.66 & 31.25 & 4.096 & 0.535 & 1 / .547 & 10.671\end{array}$ $\begin{array}{lllll}0.68 & 32.50 & 4.259 & 0.556 / 2.008 / 1.098\end{array}$ $\begin{array}{llllllll}0.68 & 30.00 & 3.932 & 0.51 & 4 & 11.085 & 1 & 0.244\end{array}$ $\begin{array}{llllllll}0.68 & 32.50 & 4.259 & 0.556 & 12.008 & 11.098\end{array}$ $\begin{array}{lllllllll}0.66 & 31.75 & 4.161 & 0.544 & 11.731 & 10.842\end{array}$ $0.60, \begin{array}{lllll}27.75 & 3.637 & 0.475 & 10.253 & 9.476\end{array}$

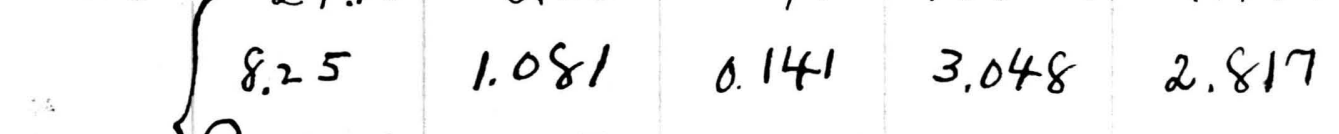

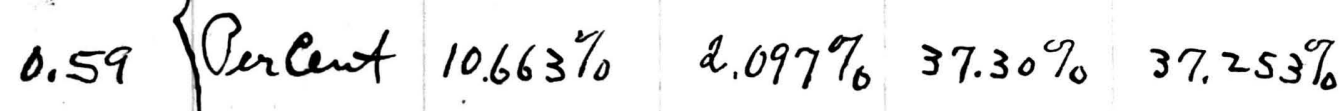
\begin{tabular}{ll|l|l|l}
19.25 & 2.050 & 0.400 & 7.18 & 7.17
\end{tabular}

2.02 $\begin{array}{lllllll}0.50 & 24.50 & 2.610 & 0.510 & 9.140 & 9.130\end{array}$ $\begin{array}{lllllll}0.42 & 20.00 & 2.130 & 0.420 & 7.460 & 7.450\end{array}$ $\begin{array}{lllllll}2.22 & 0.46 & 22.25 & 2.370 & 0.470 & 8.300 & 8.290\end{array}$ 
Bable VII Steer 48 Feed Aualysis-10 lay Periode (7 ull 7ed Period).

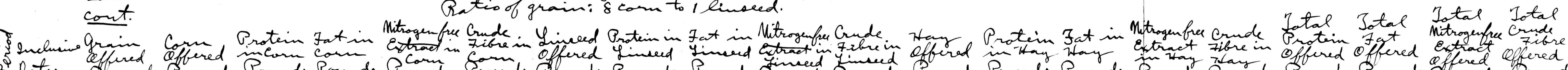

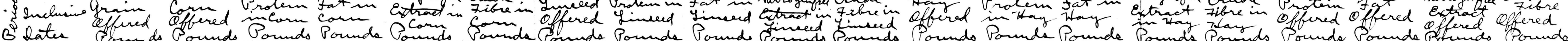

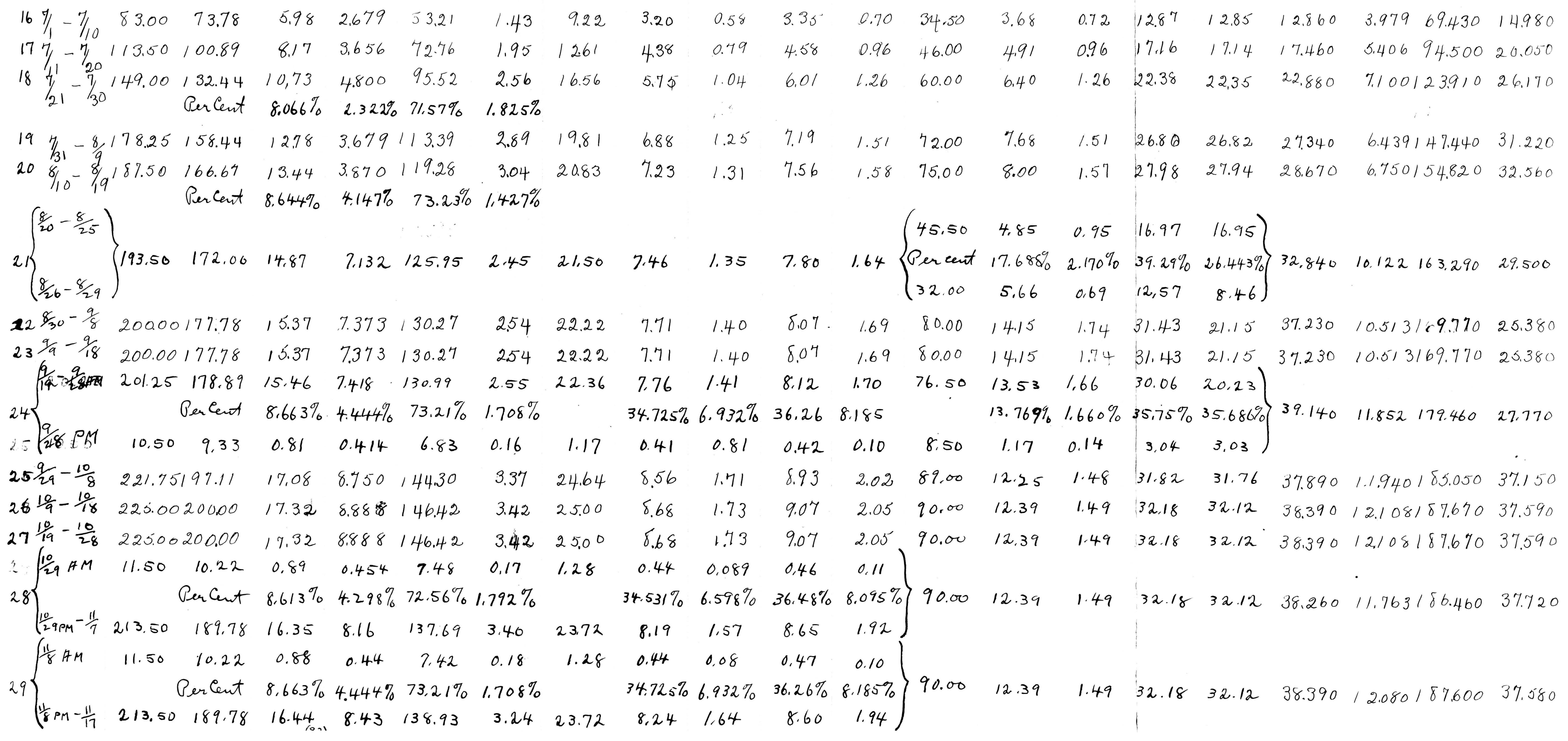




\section{Jable VII Steir 48 Feed Analyais-iollay Periode (7 ull FedPeriod)}

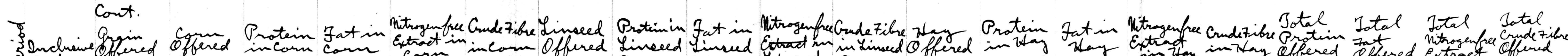

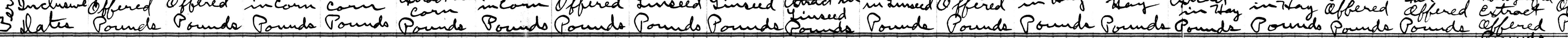

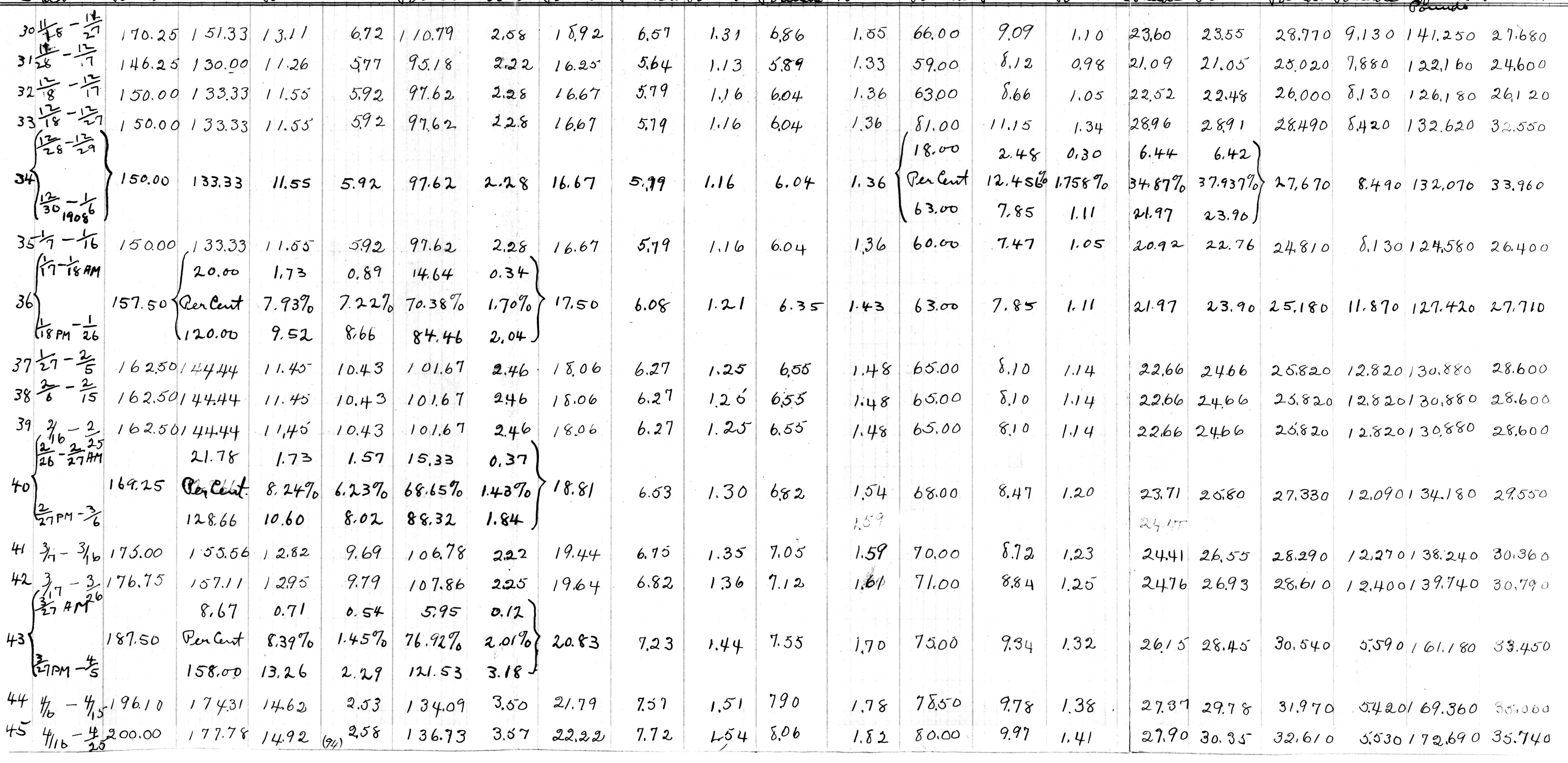




\section{Sable III Steer 48 Feed Analysis-iolay Periods (7ull 7 ed (Period).}

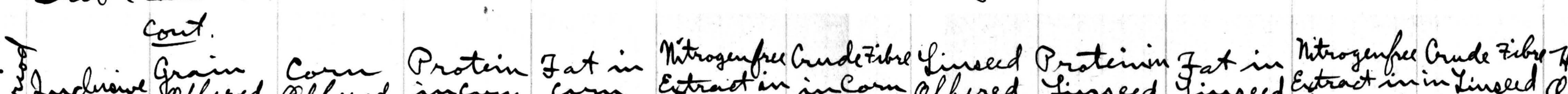

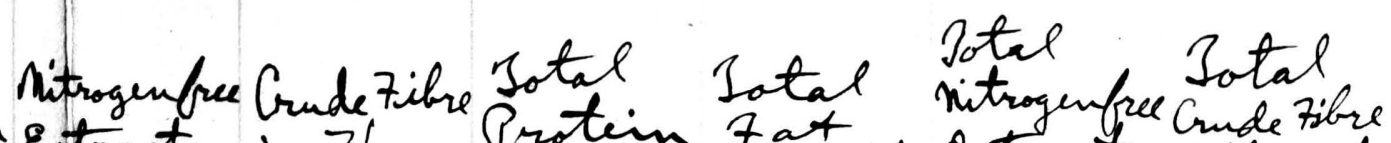

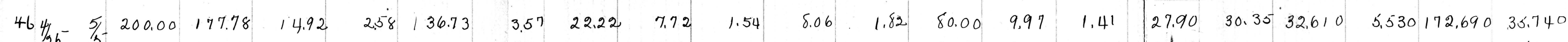

$47 \frac{5}{5}-\frac{5}{5} 200.00177 .7 .8 \cdot 14.92$

$48 \frac{5}{110}-5 / 25186.75 \quad 166.00 \quad 13.93$

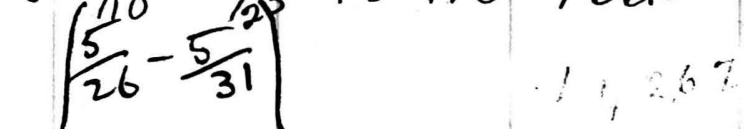

$49\left\{\frac{6}{1}-\frac{6}{4}\right\}$

$160.50 \quad 142.67 \quad 11.97$

$\begin{array}{lllllll}50 & 6 / 5 & 6 & 162.50 \quad 144.44 & 12.12\end{array}$

\begin{tabular}{lll|lll}
51 & 6 & $-6 / 2$ & 162.50 & 144.44 & 12.12
\end{tabular}

$52 \quad 6 / 25-7 / 4 \quad 171.80 \quad 152.71 \quad 12.81$

$53 \quad 7 / 5-7 / 14 \quad 183.10 \quad 162.76 \quad 13.66$

Percent $8.71 \%$

$\begin{array}{llllll}547 / 5-7 & 186.08 & 165.40 & 14.41\end{array}$

$\begin{array}{llllll}557 & -\frac{24}{3} & 190.60 & 169.42 & 14.76\end{array}$

$56 \frac{25}{8 / 4}-\frac{8}{13} \quad 192.80 \quad 171.38 \quad 14.93$

$\begin{array}{llllll}578 \% & 83 & 196.00 & 173.33 & 15.10\end{array}$

$\left\{\begin{array}{l}\frac{8}{24}-\frac{87}{31} \\ 58\end{array}\right.$

$58\left\{\frac{9}{1}-\frac{9}{2}\right\}$

$59 \frac{9}{3}-q / 1211.30 \quad 187.82 \quad 16.36$

$60 q_{13}^{3}-\frac{9}{22} 198.75 / 76.67$

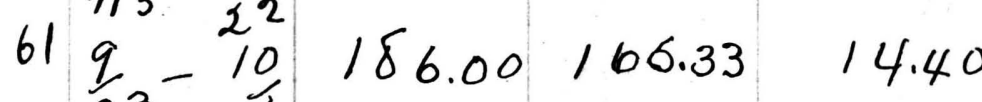

$62 \frac{10}{23}-\frac{10}{12} 182.00161 .78 \quad 14.09$

$63 \frac{10}{13}-\frac{10}{22} 182.75^{\prime} 162.44 \quad 1.4 .15$

$64 \begin{aligned} & 13 \\ & 10\end{aligned}-\frac{11}{1} \mid 77.50 \quad 157.78 \quad 13.74$.
$2,58 \quad 136.73$

2.41127 .68

$3.57 \quad 22.22$

2.

207109.73

2. 0 ?

2.09111 .11

2.09111 .1

$2.21 \quad 117.47$

$2.36 \quad 12519$

$3.10 \% 74.90 \%$

$5.13 \quad 123.88$

$5.25 \quad 126.90$

$5.31 \quad 128.36$

$5.37 \quad 129.82$

$5.37 \quad 129.8$

5.82140 .69

$5.48 \quad 132.32$

5.13123 .82

$502 \quad 121.17$

$5.04 \quad 121.66$

$4.89,1+8.7$

$2.87 \quad 17.83$

-

$290 \quad 18.06$

$2.90 \quad 18.06$

$3.27 \quad 20.34$

$1.71 \%$

$283 \quad 2068$

$290 \quad 21.18$

$2.93 \quad 21.42$

296.21 .67

$296 \quad 21.67$

$3.21 \quad 23.48$

$3.02 \quad 2208$

$283 \quad 20.67$

$2.77 \quad 20.22$

$2.78 \quad 20.31$

$2.70 \quad 19.72$
7.72
7.72

7.21

1.54

806

$1.8280 .00 \quad 9,97$

$1.70 \quad 7400 \quad 9.22 \quad 1.30$

$3.07 \quad 19.09$
$6.27 \quad 1.25$

$6.27 \quad 1.25$

6.63

7.06

7.18

7.35

7.44

7.52

752

1.50

8.15

7.67

1.63

1.53

1.43

1.40

1.4

1.37

6.55

6.55

6.92

7.38

7.50

7.68

7.77

7.86

7.8

8.5

7.33

7.15
$6.19 \quad 1.24 \quad 6.47$

\section{$1.46\left\{\begin{array}{ccc}39.00 & 4.86 & 0.69 \\ \text { Percent } & 12.456 \% & 1.758 \% \\ 26.00 & 3.24 & 0.46\end{array}\right.$}

$\begin{array}{lll}1.48 & 65.00 & 8.10\end{array}$

$\begin{array}{lll}1.48 & 47.50 & 5.92\end{array}$

$156 \quad 68.69 \quad 8.56$

$1.69 \quad 7266 \quad 9.05$

1.7

$1.75^{\prime}$

$76.30 \quad 9.50$

$1.77 \quad 78 / 8$

$77.26 \quad 9.6$

$950: 134$

28

34

36

$\left(\begin{array}{cc|}62.48 & 7.78\end{array}\right.$

15,62

\begin{tabular}{|c|c|}
\hline $12.163 \%$ & $2.58 \%$ \\
1.90 & 0.40
\end{tabular}

$\begin{array}{lllll}1.92 & 78.83 & 9.59 & 2.03\end{array}$

$\begin{array}{lll}1.81 & 77.90 & 9.48\end{array}$

$\begin{array}{llll}7.49 & 1.69 & 72.38 & 8.80\end{array}$

1.65

1.66
$27.90 \quad 30.35 \quad 32.610 \quad 5.530172 .690 \quad 35.740$

$\begin{array}{lllllll}25.80 & 28.07 & 30.360 & 5.150 & 161.000 & 33.110\end{array}$

\begin{tabular}{l|l|l|l|l|l|}
13.60 & 14.79 \\
\hline $4.87 \%$ & $37.937 \%$
\end{tabular}$\quad 4.460: 00.69$

$4.460138 .870 \quad 28.980$

$4.87 \% \quad 37.937 \%\} 26.260$

$\begin{array}{lll}22.66 & 24.66 & 26.490\end{array}$

$4.480140 .320 \quad 29.040$ $4.180134 .220 \quad 22.400$ $4.740148 .340 \quad 30.690$ $5.060 / 58.100 \quad 32.710$

$1.840156 .720 \quad 32.080$ $8.060 .161 .190 \quad 33.570$ $8.150 \quad 163.070 \quad 33.990$ $8.240164 .910 \quad 34.360$

$697 \% \quad 32.26 \%$ $\left.\begin{array}{l}23.70 \\ 0.697 \% \\ 32.26 \%\end{array}\right\}$ \begin{tabular}{l|l|l|}
\hline & 5.04 \\
\hline
\end{tabular}

$\begin{array}{lllll}32.08 & 25.43 & 34.100 & 9.480181 .280 & 30.560\end{array}$ $\begin{array}{lllllll}31.70 & 25.13 & 32.540 & 9.020172 .030 & 29.960\end{array}$ $\begin{array}{lllllll}29.46 & 2335 & 30.370 & 8.430 / 60.770 & 27.870\end{array}$ $\begin{array}{llllll}29.57 & 23.44 & 29.950 & 8.290158 .070 & 28.860\end{array}$ $\begin{array}{llllll}29.72 & 23,56 & 30.080 & 8.330158 .740 & 28.000\end{array}$ $\begin{array}{llllll}29.00 & 22.98 & 2.9 .260 & 8.100154,320 & 27.290\end{array}$ 
Jable VII Steer48 Feed Analysia-10 day Periode (7ullzed Period).

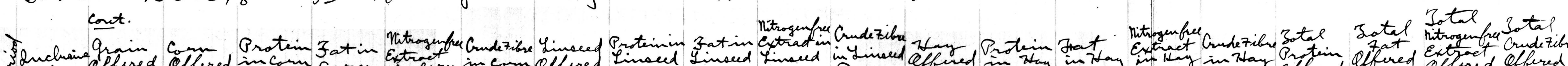

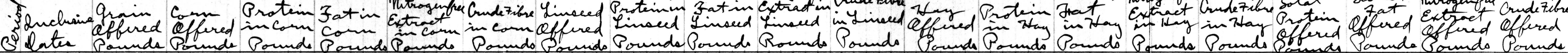
are Saundo Soundo Pounde

\begin{tabular}{|c|c|c|c|c|c|c|c|c|c|c|c|c|c|c|c|c|c|c|c|}
\hline $65^{\frac{1}{2}-\frac{11}{11}}$ & 177.50 & 157,78 & 13.74 & 4,89 & 118.17 & 2.70 & 1.9 .72 & 6.85 & 1.37 & 7.15 & 1.61 & 71.26 & $\delta, 67$ & 1.84 & 29,00 & 22.98 & 29.260 & 8.100154 .320 & 27.290 \\
\hline $1 \frac{11}{12}$ & 177.50 & $15,7.78$ & 3.74 & 4.89 & 118.17 & 2.70 & 19.72 & 6.85 & 1.37 & 7.15 & 1.61 & 68.26 & 8.30 & 1.76 & 27,78 & 22.02 & 28.890 & $8.020 / 53.100$ & 26,330 \\
\hline & 172.80 & $\begin{array}{l}153.33 \\
130.44\end{array}$ & $\begin{array}{l}13.35 \\
11.36\end{array}$ & $\begin{array}{l}4.76^{\prime} \\
4.04\end{array}$ & $\begin{array}{l}114.84 \\
97.70\end{array}$ & $\begin{array}{l}2.62 \\
2.23\end{array}$ & 19.17 & 6.66 & 1.33 & $695^{\prime}$ & 1.57 & 69.76 & 8.49 & 1.80 & 28,39 & 22.50 & 28.500 & $7.880 \quad 150.180$ & 26.690 \\
\hline & 172.50 & & $\begin{array}{c}8.59 \% \\
1.97\end{array}$ & $\begin{array}{c}3.52 \% \\
0.81\end{array}$ & $\begin{array}{l}73.06 \% \\
16.77\end{array}$ & $\begin{array}{r}2.10 \% \\
0.48\end{array}$ & 19.17 & 6.66 & 1.33 & 6.95 & 1.57 & 68.75 & 8,86 & 1.77 & 27.98 & 22.18 & 28.350 & 7.950149 .350 & 26.460 \\
\hline & 171.00 & 152.00 & 13.06 & 5.36 & $1 / 1.05$ & 3.1 .9 & 19.00 & 6.60 & 1.32 & 6.89 & 1.56 & 63,50 & 9.72 & 1.64 & 25.84 & 20.48 & 27.380 & 8.320143 .780 & 25.230 \\
\hline & 177.50 & 157.78 & 13.55 & 5.56 & 115.27 & 3,31 & 19.72 & $6.85^{\circ}$ & 1.37 & 7.15 & 1.61 & 61.50 & 7.48 & 1.59 & 25.03 & 19.84 & 27.880 & $8.520 / 47.450$ & 24.760 \\
\hline$\frac{1}{10}$ & 175.00 & 155,56 & 13.37 & 5.48 & 113.65 & 3.27 & 19,44 & $6.75^{\prime}$ & 1.35 & 9.05 & 1.59 & 67.50 & 8.21 & 1.74 & 27.47. & 21.47 & $28.330^{\circ}$ & 8.570148 .170 & 26.630 \\
\hline 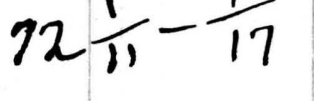 & 127.50 & $1,3.33$ & 9.74 & 3.99 & 82.80 & 2.38 & 14.17 & 4.90 & 0.98 & 5.12 & 1.16 & 51.50 & 6.26 & 1.33 & 20.96 & 16.61 & 20.900 & 6.300108 .880 & 20.150 \\
\hline
\end{tabular}




\section{Iable VIII Steer 48 Refused Feed Anilysis-10dldy' Periods.}

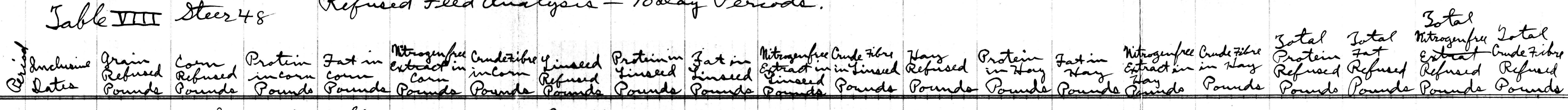

1907 See note Jable VII PerCent 10.138\% 1.475\% 36.23\% 37.705\% Perlent 10.138\% 1.475\% 36.23\% 37.905\%

\begin{tabular}{l|l|l|l|l|l|l|l|l|l|l|l|l|l|l|l|l|l}
$19 \frac{7}{31}-\frac{8}{9}$ & Percent $8.066 \%$ & $2.322 \%$ & $71.57 \%$ & $1.825 \%$ & $34.713 \%$ & $6.290 \%$ & $36.30 \%$ & $7.607 \%$ & 2.00 & 0.203 & 0.030 & 0.725 & 0.758
\end{tabular}

\begin{tabular}{ll|l|l|l|l|l|l|l|l|l|l|l|l|l|l}
$34.713 \%$ & $6.290 \%$ & $36.30 \%$ & $7.607 \%$ & 2.00 & 0.203 & 0.030 & 0.725 & 0.758 & 0.203 & 0.030 & 0.725 & 0.758
\end{tabular}

$208 / 10-8 / 19$

\begin{tabular}{l|l|l|l|l|l|l|l|}
50 & 1.333 & 0.108 & 0.031 & 0.954 & 0.024 & 0.167 \\
\hline
\end{tabular}

\begin{tabular}{llllllll|l|l|l|l|l}
0.058 & 0.011 & 0.061 & 0.013 & 16.50 & 1.673 & 2.434 & 5978 & 6.254
\end{tabular}

$\begin{array}{llll}1.839 & 2.476 & 6.993 & 6.291\end{array}$

$21\left\{\begin{array}{l}\frac{8}{20}-\frac{8}{21} \\ \frac{8}{22}-\frac{8}{29}\end{array}\right\} 1$

Perent $8.644 \% \quad 4.147 \% \quad 73.23 \% \quad 1.427 \%$

$2 \frac{8}{30}-\frac{9}{8}$

$2.3 \frac{9}{9}-\frac{9}{18}$

$\begin{array}{lllllll}0.889 & 0.077 & 0.037 & 0.651 & 0.013 & 0.111\end{array}$

$0.039 \quad 0.007$

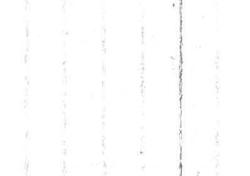

$\left(\begin{array}{llllll}1.50 & 0.152 & 0.221 & 0.543 & 0.569\end{array}\right)$

0.50

\begin{tabular}{l|l|l|l|l|l|}
0.444 & 0.038 & 0.018 & 0.325 & 0.006 & 0.056
\end{tabular}

$0.019 \quad 0.004$

$0.040 \quad 0.0$

$0.008\left\{\begin{array}{c}1.50 \\ 0.50\end{array}\right.$

$\left.\begin{array}{ccccc}14.400 \% & 1.814 \% & 38.12 \% & 32.258 \% \\ 0.072 & 0.009 & 0.191 & 0.161\end{array}\right\}$

$0.340 \quad 0.274 \quad 1.425 \quad 0.751$

$24 \frac{9}{19}-\frac{9}{28}$

nove

0.018

$\begin{array}{lllllllll}0.020 & 0.004 & 0.50 & 0.072 & 0.009 & 0.191 & 0.161\end{array}$

$\begin{array}{llll}0.129 & 0.031 & 0.536 & 0.171\end{array}$

$4.444 \quad 0.384$

\begin{tabular}{ll|l|l|l}
0.184 & 3.254 & 0.063 & 0.556
\end{tabular}

$0.193 \quad 0.035 \quad 0.202 \quad 0.042$ none

Rerlent $8.663 \%$

$4.444 \%$ 73.21\% $1.708 \%$ Percent

25

$25 \frac{9}{29}-\frac{10}{8}$

$\begin{array}{llllll}0.188 & 3.091 & 0.072 & 0.528\end{array}$

$4.725 \% \quad 6.932 \%$

$36.26 \%$$$
\begin{array}{lllll}
0.099 & 1.627 & 0.038 & 0.278
\end{array}
$$

0.183
0.097

$\begin{array}{llllll}0.037 & 0.191 & 0.043 & 14.50\end{array}$

$\begin{array}{lllll}11.931 \% & 2.132 \% & 34.54 \% & 37.025 \%\end{array}$

$\begin{array}{lllll}26 \frac{10}{9}-\frac{10}{18} & 2.50 & 2.222 & 0.192\end{array}$

$27 \frac{10}{19}-\frac{10}{28}$

$\begin{array}{lllll}0.099 & 1.627 & 0.038 & 0.27\end{array}$

$28 \frac{10}{29}-\frac{11}{7}$ mone

$29 \frac{11}{8}-\frac{11}{17}$

\begin{tabular}{l|l|l}
81.00 & 72.00 & 6.238
\end{tabular}

$\begin{array}{lllll}3.200 & 52.711 & 1.230 & 9.000\end{array}$

$30 \frac{11}{18}-\frac{11}{27}$

$\begin{array}{llll}85.25 & 75.777 & 6.565\end{array}$

$31 \frac{11}{28}-\frac{12}{72}$

$52.00 \quad 46.222 \quad 4.004$

$3.366 \quad 55.476 \quad 1.294 \quad 9.473$

\begin{tabular}{ll|l|l|l|}
2.054 & 33.839 & 0.789 & 5.778
\end{tabular}

3.289

0.624

$\begin{array}{lllll}1.730 & 0.309 & 5.008 & 5.369\end{array}$

nome nome mome mone

$\begin{array}{llll}0.577 & 0.219 & 3.456 & 0.105\end{array}$

$32 \frac{12}{8}-\frac{12}{17}$

$29.25 \quad 26.000 \quad 2.252$

$\begin{array}{llllll}1.155 & 19.035 & 0.444 & 3.250\end{array}$

$2.006 \quad 0.401$

3.263

1.00
mone
Percent

\begin{tabular}{ll|l|l|l}
0.119 & 0.021 & 0.345 & 0.370
\end{tabular}

$2.279 \quad 0.534 \quad 8.290 \quad 5.484$

$\begin{array}{llllll}1.718 & 28.308 & 0.660 & 4.83\end{array}$

$1.129 \quad 0.225$

3.435

$\begin{array}{lllllll}18,25 & 1.899 & 0.281 & 6.243 & 7.510\end{array}$

Perlent 10.144\% $1.350 \% \quad 34.80 \% \quad 35.509 \%$

$33 \frac{12}{18}-\frac{12}{27}$

$38.667 \quad 3.350$

$\begin{array}{llllll}0.425 & 6.996 & 0.163 & 1.194\end{array}$

$\begin{array}{lll}1.678 & 0.335\end{array}$

0.473

1.178

\begin{tabular}{l|l|l|l|l|l}
0.737 & 16.75 & 1.699 & 0.226 & 5.829 & 5.948
\end{tabular}

$\begin{array}{lllll}0.408 & 0.139 & 2.071 & 0.431\end{array}$

nome none mone rome

(97) 
Bable VIII Steer 48 Refused Feed Analyirs - 10 Day Reriods.

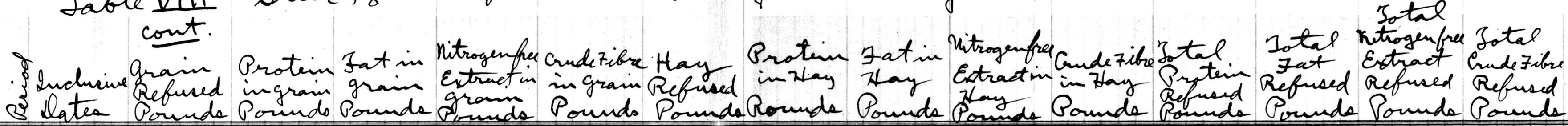

\begin{tabular}{|c|c|c|c|c|c|c|c|c|c|c|c|c|c|c|}
\hline 1908 & Pertent & $11.34 \%$ & $3.47 \%$ & $67.59 \%$ & $2.15 \%$ & & & & & & & & & \\
\hline $35 \frac{1}{7}-$ & 17.25 & 1.956 & 0.599 & 11.659 & 0.371 & mone & & & & & 1.956 & 0.599 & 11.659 & 0.371 \\
\hline $36 \frac{1}{17}-\frac{1}{26}$ & 3.25 & 0.369 & 0.113 & 2.197 & 0.070 & mone & & & & & 0.369 & 0.113 & 2.197 & 0.070 \\
\hline $37 \frac{1}{27}-\frac{2}{5}$ & 26.75 & 3.033 & 0.928 & 18.080 & 0.575 & mone & & & & & 3.033 & 0.928 & 18.080 & 0.575 \\
\hline $38 \frac{2}{6}-\frac{2}{15}$ & 0.75 & 0.085 & 0.026 & 0.507 & 0.016 & none & & & & & 0.085 & 0.026 & 0.507 & 0.016 \\
\hline $39 \frac{2}{16}$ & none & & & & & mone & & & & & none & mone & rone & mone \\
\hline $40 \frac{2}{26}-\frac{3}{6}$ & 13.75 & 1.559 & 0.477 & 9.294 & 0.296 & none & & & & & 1.559 & 0.477 & 9.294 & 0.296 \\
\hline $41 \frac{3}{7}-\frac{3}{16}$ & 3.25 & 0.369 & 0.113 & 2.174 & 0.070 & none & & & & & 0.369 & 0.113 & 2.197 & 0.070 \\
\hline $42 \frac{3}{17}$ & nove & $11.29 \%$ & $4.04 \%$ & $70.91 \%$ & $2.82 \%$ & mone & & & & & mone & none & nowe & rove \\
\hline $43 \frac{3}{27}-\frac{4}{5}$ & 5,00 & 0.565 & 0.202 & 3.546 & 0.141 & none & & . & & & 0.565 & 0.202 & 3.546 & 0.141 \\
\hline $44 \frac{7}{6}-\frac{4}{15}$ & mone & & & & & none & & & & & mone & none & mone & mone \\
\hline $45 \frac{4}{16}=$ & 1.50 & 0.169 & 0.061 & 1.064 & 0.042 & none & & & & & 0.169 & 0.061 & 1.064 & 0.042 \\
\hline $46 \frac{4}{26}$ & 12.50 & 1.411 & 0.505 & 8.864 & 0.353 & mone & & & & & 1.411 & 0.505 & 8.864 & 0.353 \\
\hline $47 \frac{5}{6}$ & 30.75 & 3.472 & 1.242 & 21.805 & 0.867 & none & & & & & 3.472 & 1.242 & 21.805 & 0.867 \\
\hline $48 \frac{5}{16}-\frac{5}{25}$ & 32.75 & 3.697 & 1.323 & 23.223 & 0,924 & Perkent & $-10.350 \%$ & $0.42 \%$ & $35.32 \%$ & $41.04 \%$ & 3.697 & 1,323 & 23,233 & 0.924 \\
\hline $49 \frac{5}{26}-\frac{6}{4}$ & 30.25 & 3.415 & 1.222 & 21.450 & 0.853 & 3.00 & 0.311 & 0.013 & 1.060 & 1.231 & 3.726 & 1.235 & 22.510 & 2.084 \\
\hline $50 \frac{6}{5}$ & 34.75 & 3.923 & 1.404 & 24.641 & 0.980 & 6.75 & 0.699 & 0.028 & 2.384 & 2.770 & 4.622 & 1.432 & 27.025 & 3.750 \\
\hline $1-52 \frac{6}{15}-7$ & mone & & & & & none & & & & & mone & mone & mone & none \\
\hline $53 \frac{7}{5}-\frac{7}{14}$ & 7.77 & 0,877 & 0.314 & 5.510 & 0.219 & nove & & & & & 0.877 & 0.314 & 5.510 & 0.219 \\
\hline $4-58 \frac{7}{15}-\frac{9}{2}$ & nove & $10,375 \%$ & $4.88 \%$ & $72.885 \%$ & $2.39 \%$ & none & & & & & mone & mone & mone & mone \\
\hline $59 \frac{9}{3}-\frac{9}{12}$ & 1.56 & 0.162 & 0.076 & 1.137 & 0.037 & none & & & & & 0.162 & 0.076 & 1.137 & 0.037 \\
\hline $60 \frac{9}{13}-\frac{9}{22}$ & 9.01 & 0,935 & 0.440 & 6.567 & 0.215 & move & & & & & 0.935 & 0.440 & 6.567 & 0.215 \\
\hline $61 \frac{9}{23}-\frac{10}{2}$ & 19.89 & 2.064 & 0.971 & 14.497 & 0.475 & nove & & & & & 2,064 & 0.971 & 14.497 & 0.475 \\
\hline $62 \frac{10}{3}-\frac{10}{12}$ & 0.75 & 0.078 & 0.037 & 8) 0.547 & 0.018 & mone & & & & & 0.078 & 0.037 & 0.547 & 0.018 \\
\hline
\end{tabular}


Iable Steer 48 Refused Feed Qinalysis - 10 day Periods.

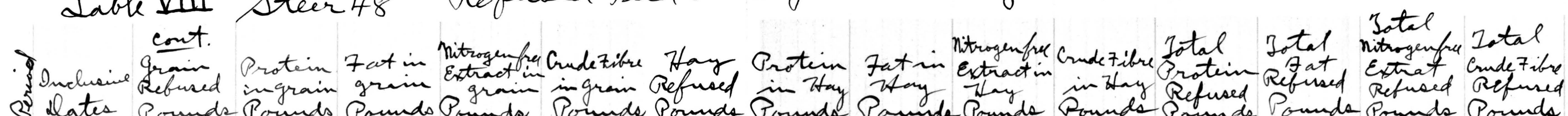

\subsection{5}

\begin{tabular}{lllll|}
0.805 & 0.379 & 5.656 & 0.185 \\
0.699 & 0.379 & 4.287 & 0.151 \\
0.135 & 0.073 & 0.825 & 0.029 \\
1.300 & 0.676 & 7.677 & 0.345 \\
0.331 & 0.143 & 2.020 & 0.070 \\
2.620 & 1.021 & 14.390 & 0.910 \\
0.346 & 0.149 & 2.108 & 0.073 \\
mone. mone mone mane & & \\
\hline mone mone mone mone & & \\
\hline mone mone mone mone
\end{tabular}




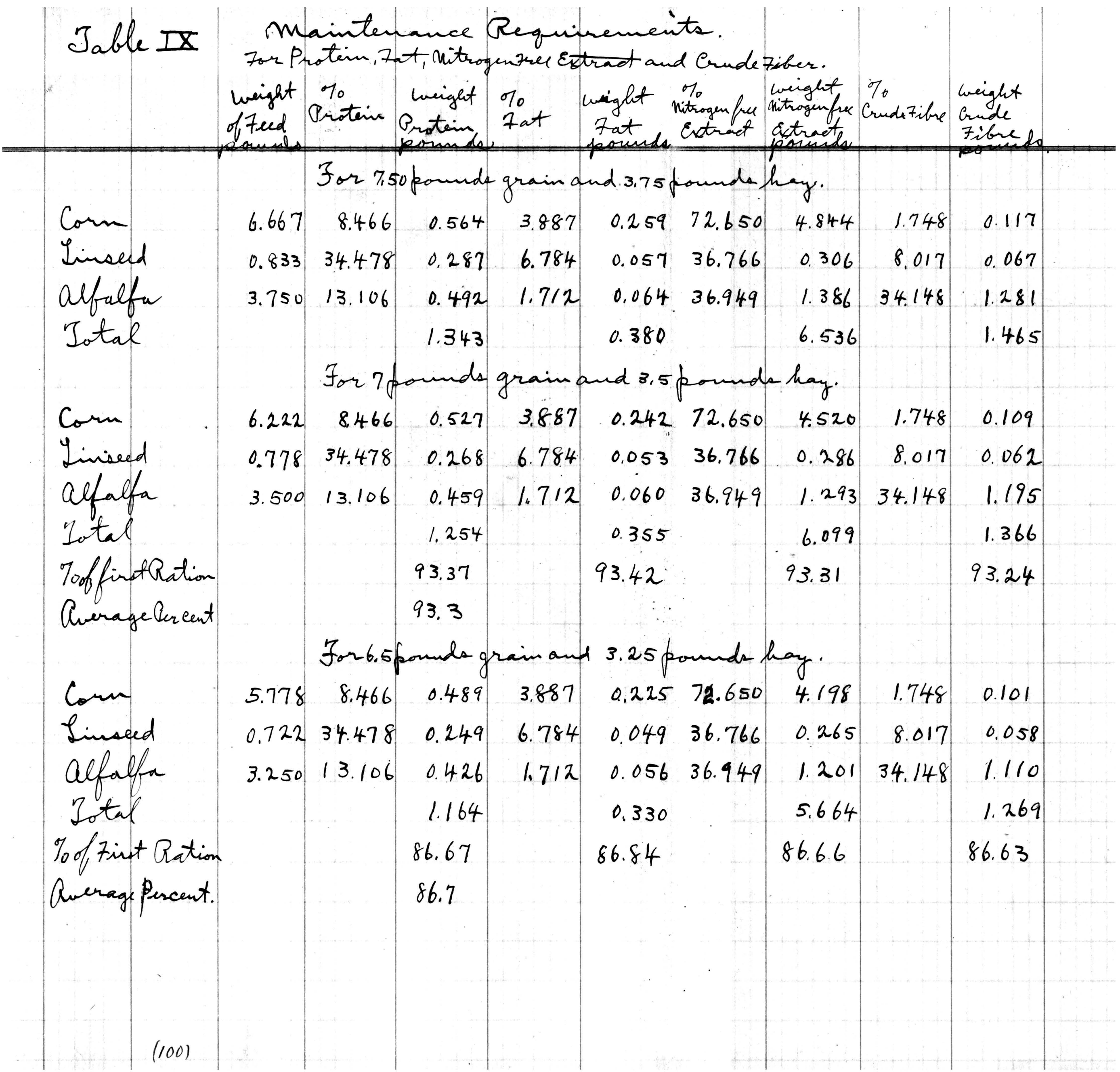


Lable X Steer 121 maintenance Ration
and our
Average Qualyses

Nes. Lim

- Ayimal Proteim Regniremat Protein Requirement Protein

G Period Connde Peniod Requiremat Perio mant per 1000 Slo perday

1.254

1.245

\begin{tabular}{lll|l|l|l|l}
17 & 778.0 & 13.241 & 9.756 & 3.485 & 9.686
\end{tabular}

$\begin{array}{llllllll}18 & 805.9 & 19.755 & 10.106 & 9.649 & 10.033\end{array}$

$19 \quad 858.6 \quad 23.482 \quad 10.767 \quad 12.7 / 5 \quad 10.689$

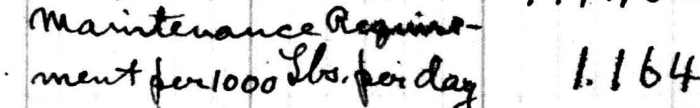

1.157

$21 \quad 933.8 \quad 30.536 / 0.869 / 9.667 \quad 10.804 \quad 19.732 \quad 9.399$

$22974.233 .937 / 1.34022 .597 / 1.271 \quad 22.666 \quad 9.703$

$\begin{array}{llllllllllll}23 & 997.8 & 36.740 & 11.614 & 25.126 & 11.545 & 25.195 & 10.355\end{array}$

$241056.3 \quad 38.692 \quad 12.29526 .397 \quad 12221 \quad 26.471 \cdot 10.971$ $25 / 097.4 \quad 36.996 \quad 12.774 \quad 24.222 \quad 12.697 \quad 24.299 \quad 11.746$ $\begin{array}{lllllllllll}26 & 1 & 33.3 & 34.740 & 13.192 & 21.548 & 13.112 & 21.628 & 10.963\end{array}$ $27 \quad 132.7 \quad 34.153 / 3.185 \quad 20.968 / 3.105 \quad 21.048 \quad 10.739$ $28 / 190.3 \quad 37.725 / 3.85523 .870 \quad 13.772 \quad 23.953 \quad / 1.902$ $291211.938 .011 \quad 14.10723 .904 / 4.02223 .989 \quad 10.992$ $\begin{array}{lllllllllll}30 & 1208.9 & 32.694 & 14.072 & 18.622 & 13.987 & 18.707 & 10.175\end{array}$ $31 / 258.132 .472 / 4.645 / 7.827 \quad 14.556 / 7.916 \quad 10.18$ $32 / 261.3 / 0.241 \quad 4.405 \quad 5.836 \quad 4.379 \quad 5.862 \quad 2.814$ Sotal 560. $476.97 / 188.434288 .537 / 87.248289 .223 / 41.35453 .40587 .979$ Jotal Ks. 216.349 0.330 $131.415 \quad 64.130$ ption of Constituents.

maintenance Ration Requirement leterAverage Qualyses limimanghnintenance

Maintenance Bation Gequimement lleterand our mimed From Prelim Average Amolyses imanymaintenand

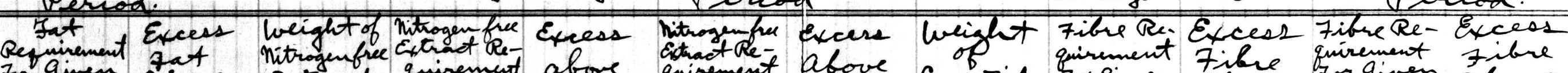
Querage Analyes. Liminary maintenance

Escentenand

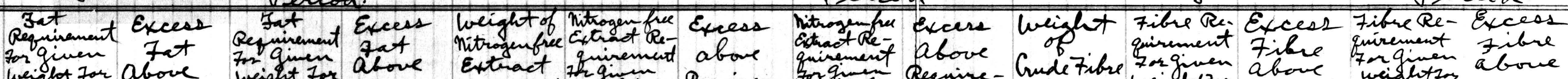

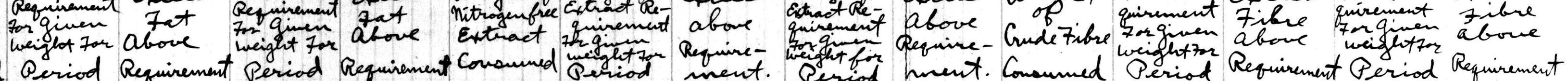

$0.355 \quad 0.353$ 6.099 6.348 1.366 1.339

$2.762 \quad 1.343 \quad 2.746$ $1.35971 .655 \quad 47.450 \quad 24205+9.38$ $\begin{array}{lllllllllllllll}3.292107 .1 & 10 & 49.152 & 57.958 & 51.159 & 55.951 & 22.495 & 1 & 1.008 & 11.487 & 10.792 & 11.703\end{array}$ $\begin{array}{llllllllllll}2.517127 .139 & 52.366 & 74.773 & 54.503 & 72.636 & 26.889 & 11.728 & 15.161 & 11.497 & 15.392\end{array}$ \begin{tabular}{ll|l|l|l|l|l|l|l|l|l|l|l|l|}
2.430129 .292 & 55.696 & 73.596 & 57.971 & 71.321 & 24.478 & 12.474 & 12.004 & 12.228 & 12.250
\end{tabular} $3242 \quad 2412 \quad 3224$ 0.328 $\begin{array}{llll}3.082 & 6.317 & 3.063\end{array}$ $\begin{array}{llll}3.215 & 6.488 & 3.195\end{array}$ $3.293=7062 \quad 3.273$ $\begin{array}{llll}3.486 & 7.485 & 3.465\end{array}$ $\begin{array}{llll}3.621 & 8.125 & 3.599\end{array}$ $\begin{array}{llll}3.740 & 7.223 & 3.71\end{array}$ $\begin{array}{llll}3.738 & 7.001 & 3.715\end{array}$ $\begin{array}{llll}3.928 & 7.974 & 3.904\end{array}$ $3.999 \quad 6.9 .93 \quad 3.975$ $3.989 \quad 6.186 \quad 3.965$ $\begin{array}{lll}4.152 & 6.029 \quad 4.12\end{array}$ 241 3.085 
Table XI Ster 48

Maintenance Ration Requiremant lleter-

Average Analyses. Liminarymainte-

Mailable Productive Consumption of Constituente.

\begin{tabular}{|c|c|c|c|c|c|c|c|c|c|c|c|c|c|c|c|c|c|c|c|c|c|}
\hline & & & $\begin{array}{l}\text { maintena } \\
\text { and or } \\
\text { Average }\end{array}$ & $\begin{array}{l}\text { medration } \\
\text { mer } \\
\text { malyses. }\end{array}$ & $\begin{array}{l}\text { Reginement } \\
\text { Limined for } \\
\text { nance G }\end{array}$ & $\begin{array}{l}\text { Alleter- } \\
\text { rom Pre- } \\
\text { gimainte- } \\
\text { Period. }\end{array}$ & & $\begin{array}{l}\text { Maintenan } \\
\text { and } 0 \\
\text { Average }\end{array}$ & $\begin{array}{l}\text { ncelation } \\
\text { our } \\
\text { Aualyses }\end{array}$ & $\begin{array}{l}\text { Requinement } \\
\text { mined from } \\
\text { inary Mai }\end{array}$ & $\begin{array}{l}\text { Brelinn- } \\
\text { intenance } \\
\text { iod. }\end{array}$ & & $\begin{array}{l}\text { Maintenanc } \\
\text { and o } \\
\text { Average Q }\end{array}$ & $\begin{array}{l}\text { el Ration } \\
\text { ur } \\
\text { inalyser }\end{array}$ & $\begin{array}{l}\text { Requiremai } \\
\text { mined Fro } \\
\text { liminary Mi } \\
\text { Peri }\end{array}$ & $\begin{array}{l}\text { od deler- } \\
\text { anitenance } \\
\text { od }\end{array}$ & & $\begin{array}{l}\text { Maintenan } \\
\text { and o } \\
\text { Average } \text { An }^{2}\end{array}$ & malyses. & inang frov & $\begin{array}{l}\text { A Deter } \\
\text { n Prelinm } \\
\text { intenance } \\
\text { iod }\end{array}$ \\
\hline$\$$ & $\begin{array}{l}\text { lueight of } \\
\text { Animal } \\
\text { 7or } \\
\text { Period }\end{array}$ & $\begin{array}{l}\text { loeight of } \\
\text { Protin } \\
\text { Consunnd } \\
\text { Pounds }\end{array}$ & $\begin{array}{l}\text { Protein } \\
\text { Requirement } \\
\text { For Given } \\
\text { weight } \\
\text { Period }\end{array}$ & $\begin{array}{l}\text { Excess } \\
\text { Orotein } \\
\text { above } \\
\text { Require- } \\
\text { ment. }\end{array}$ & $\begin{array}{l}\text { Protain } \\
\text { Requirement } \\
\text { 7or Given } \\
\text { weight } \\
\text { For } \\
\text { Period }\end{array}$ & $\begin{array}{l}\text { Excess } \\
\text { Protim } \\
\text { above } \\
\text { Require- } \\
\text { ment. }\end{array}$ & $\begin{array}{l}\text { loright } \\
\text { of } 7 \text { at } \\
\text { Consumed }\end{array}$ & $\begin{array}{l}\text { Fat } \\
\text { Requinement } \\
\text { tor given } \\
\text { Wright } \\
\text { Par } \\
\text { Period }\end{array}$ & $\begin{array}{l}\text { Excess } \\
\text { 7at } \\
\text { above } \\
\text { Require } \\
\text { ment. }\end{array}$ & $\begin{array}{l}\text { Fat } \\
\text { Cequinement } \\
\text { 7or given } \\
\text { Lueight } \\
\text { For } \\
\text { Period }\end{array}$ & $\begin{array}{l}\text { Excess } \\
\text { Fat } \\
\text { above } \\
\text { Requine- } \\
\text { ment }\end{array}$ & $\begin{array}{l}\text { lueight } \\
\text { nitrogenfree } \\
\text { Estract } \\
\text { Consunued }\end{array}$ & 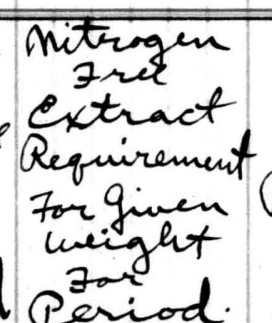 & $\begin{array}{l}\text { Axcess } \\
\text { aboul } \\
\text { Require- } \\
\text { ment. }\end{array}$ & 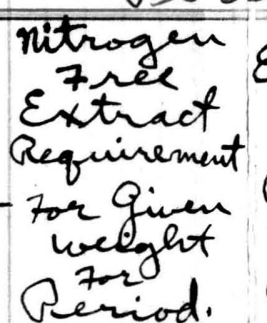 & $\begin{array}{l}\text { Excess } \\
\text { abour } \\
\text { Require- } \\
\text { ment. }\end{array}$ & $\begin{array}{l}\text { Weigh } \\
\text { of } \\
\text { Gude } \\
\text { tibre } \\
\text { Consum }\end{array}$ & $\begin{array}{l}\text { Fibre } \\
\text { Requirement } \\
70 \text { given } \\
\text { meight } \\
70 \text { s } \\
\text { Beriod }\end{array}$ & $\begin{array}{l}\text { Ekcesd } \\
\text { Fibre } \\
\text { above } \\
\text { Require- } \\
\text { ment. }\end{array}$ & $\begin{array}{l}\text { Fibre } \\
\text { Requine- } \\
\text { Fonitum } \\
\text { lonight } \\
\text { Fon } \\
\text { Period }\end{array}$ & $\begin{array}{l}\text { Excess } \\
\text { Fibre } \\
\text { above } \\
\text { Qequire- } \\
\text { ment. }\end{array}$ \\
\hline & $\begin{array}{l}\text { Maintenanc } \\
\text { ment feer } 10000^{\circ}\end{array}$ & $\begin{array}{l}\text { ce Reguire- } \\
\text { otbsperday }\end{array}$ & 1.254 & & 1.260 & & & 0.355 & & 0.357 & & & 6.099 & & 6.407 & & & 1.366 & & 1.338 & \\
\hline 16 & 849.9 & 12.860 & 10.658 & 2,202 & 10.709 & 2.151 & 3.999 & 3.017 & 0.962 & 3.034 & 0.945 & 69.430 & 51,834 & 17.596 & 54.455 & 14.975 & 14.980 & 11.610 & 3.370 & $1 / 1.372$ & 3.608 \\
\hline 17 & 866.5 & 17.460 & 10.866 & 6.594 & 10.918 & 6.542 & 5.406 & 3.076 & 2.330 & 3.093 & $2,3 / 3$ & 94.500 & 52.849 & 41.651 & 55.517 & 38.983 & 20,050 & 11.837 & 8.213 & 11.594 & 8.456 \\
\hline 18 & 917.5 & 22.880 & 11.506 & 11.374 & 11.060 & 11.320 & 7.100 & 3.257 & 3.843 & 3.276 & 3.824 & +123.910 & 55.959 & 67.951 & 58.784 & 65.126 & 26.170 & $12,53 \cdot 3$ & 13.637 & 12.276 & 13,894 \\
\hline 19 & $\begin{array}{r}992.9 \\
\text { maintenance } \\
\text { ment per } 1000\end{array}$ & $\begin{array}{l}27.137 \\
\text { e Requine- } \\
\text { otbeproday }\end{array}$ & $\begin{array}{r}12.451 \\
1.164\end{array}$ & 14.686 & $\begin{array}{r}12.510 \\
1.170\end{array}$ & 14.627 & 6.409 & $3,525^{\prime}$ & 2.8 .84 & $\begin{array}{l}3.545 \\
0.332\end{array}$ & 2.864 & +146.715 & $\begin{array}{c}60.559 \\
5.664\end{array}$ & 86.156 & $\begin{array}{r}63.615 \\
5.954\end{array}$ & 83.100 & 30.462 & $\begin{array}{r}13.563 \\
1.269\end{array}$ & 16.899 & $\begin{array}{l}13.283 \\
1.243\end{array}$ & 17.177 \\
\hline 20 & 1012.3 & 26.831 & 11.784 & 15.047 & 11.845 & 14.986 & 4.274 & 3.341 & 0.933 & 3.361 & $0.9 / 3$ & $3 / 47.827$ & 57.337 & 90.490 & 60.272 & 87.555 & 26.269 & 12.847 & 13.422 & 12.584 & 13.685 \\
\hline 21 & 1012.6 & 32.500 & 11.788 & 20.71 .2 & 11.848 & 20.652 & 9.848 & 3.342 & 6.506 & 3.362 & 6.486 & .161 .865 & 57,3541 & 104.511 & 60.2901 & 101.575 & 28.749 & 12.850 & 15.899 & 12,588 & 16.161 \\
\hline 22 & 1054.1 & 37.101 & 12.270 & 24.831 & 12.333 & 24.768 & 10.482 & 3.478 & 7.004 & 3,500 & 6.982 & 169.234 & 59.706 & 109.528 & 62.760 & 06.474 & 25.209 & 13.377 & 11.832 & 13.102 & 12.107 \\
\hline 23 & 1076.6 & 37.230 & 12.532 & 24.698 & 12.597 & 24.633 & $10.5,3$ & 3.553 & 0,960 & 3.574 & 6.939 & 169.770 & 60.980 & 108.790 & 64.099 & 105,671 & 25.380 & 13,662 & 11.718 & 13.382 & 11.998 \\
\hline 24 & 1118.7 & 38,563 & 13.023 & 25.540 & 13.090 & 25,473 & 11.633 & 3.692 & 7.941 & 3.714 & 7.919 & 9176.004 & 63.365 & 112,639 & 66.607 & 09.397 & 27.665 & 14.196 & 13.469 & 13.906 & 13.759 \\
\hline 25 & 1150.8 & 35.611 & 13.395 & $22: 216$ & $=13.465$ & 22.146 & 11.406 & 3.798 & 7.608 & 3.821 & 4.583 & 176.760 & 65.1831 & 111.577 & 68.5201 & 108.240 & 31.666 & 14,603 & 17.063 & 14.305 & 17.361 \\
\hline 26 & 11.88 .9 & 37.982 & 13.839 & 24.143 & 13.911 & 24.071 & 11.969 & 3.924 & 8.045 & 3,947 & 8,022 & 0183.599 & 67.3411 & 118.258 & 70.787 & 14.812 & 37.159 & 15.087 & 22,072 & 14.779 & 22.380 \\
\hline 27 & 1233.2 & 38.390 & 14.356 & 24.034 & 14.429 & 23.961 & 12.108 & 4.0 .70 & 8.038 & 4.094 & 8,014 & +187.670 & 69.8481 & 117.822 & 73.422 & 14.248 & 37.590 & 15.650 & 21.940 & 1.5 .329 & 22.261 \\
\hline 28 & 1241.3 & 36,361 & 14.450 & 21.911 & 14.524 & 21.837 & 11.482 & 4,097 & 7.380 & 4.121 & $4: 361$ & 180.217 & 70.3181 & 109.899 & 73,907 & 106.310 & 30.210 & 15.752 & 14.458 & 15.430 & 14.780 \\
\hline 29 & 1242.7 & 27.928 & 14.465 & 12.863 & 14,540 & 12.788 & 8.030 & 4.101 & 3.929 & 4.126 & 3.904 & +125.797 & 70.382 & 555,415 & 73.990 & 51.807 & 29.665 & 15.770 & 13.895 & 15.448 & 14.217 \\
\hline 30 & 1210.1 & 17,623 & 14.086 & 3.537 & 14.159 & 3.464 & 4,935 & 3.993 & 0.942 & 4,017 & 0.918 & 877.902 & 68,540 & 9.362 & 72.050 & 5,852 & 21.084 & 15,355 & 5.729 & 10.041 & 6.043 \\
\hline 31 & 1181.4 & 19.010 & 13.752 & 5.258 & 13.823 & $5 . / 87$ & 5.425 & 3.899 & 1.526 & 3.922 & 1.503 & 386.226 & 66.920 & 19.306 & 70,341 & 15.885 & 23.338 & 14.992 & 8.346 & 14.685 & 8.653 \\
\hline 32 & 1193.2 & $22.6 / 9$ & 13.889 & 8.730 & 13.961 & 8.658 & 6,750 & 3,938 & 2.812 & 3.962 & 2.788 & $=105.967$ & 67.591 & 38.376 & 71.043 & 34,924 & 25.410 & 15.143 & 10.267 & 14,831 & 10.579 \\
\hline 33 & 1198.6 & 23.395 & 13.952 & 9.443 & 14.024 & 9.371 & 6.355 & 3955 & 2,400 & $3.9 \times 9$ & 2,376 & 102.384 & 67.890 & 34,494 & 71.364 & 31,020 & 31.321 & 15.210 & 16.111 & 14.899 & 16.422 \\
\hline 34 & 1220.9 & 26.024 & 14.212 & 11.812 & $.12 .285^{\circ}$ & 11.739 & 7.908 & 4029 & 3.879 & 4.054 & 8.854 & +123.586 & 69.152 & 54,434 & 72.694 & 50.892 & 32.659 & 15.493 & 17.166 & 15.1176 & 17,483 \\
\hline
\end{tabular}




\begin{tabular}{|c|c|c|c|c|c|c|c|c|c|c|c|c|c|c|c|c|c|c|c|c|c|}
\hline & $\begin{array}{l}\text { For } \\
\text { Peniod }\end{array}$ & Consuned & $\begin{array}{l}\text { Requine- } \\
\text { ment. }\end{array}$ & Protim & $\begin{array}{l}\text { Requine } \\
\text { ment. }\end{array}$ & Protein & $\begin{array}{l}\text { 7att } \\
\text { Consiumed }\end{array}$ & $\begin{array}{l}\text { Requin- } \\
\text { ment }\end{array}$ & 7 at & $\begin{array}{l}\text { Requint- } \\
\text { ment }\end{array}$ & 7at & $\begin{array}{l}\text { Ectuad } \\
\text { Consumed }\end{array}$ & $\begin{array}{l}\text { Require- } \\
\text { munt }\end{array}$ & Excess & $\begin{array}{l}\text { Require- } \\
\text { ment }\end{array}$ & Excess & $\begin{array}{l}\text { Thbere } \\
\text { Consuned }\end{array}$ & $\begin{array}{l}\text { Require- } \\
\text { meat }\end{array}$ & Excest 9 & $\begin{array}{l}\text { Requine- } \\
\text { munt }\end{array}$ & Excen \\
\hline & 1242.6 & 22.854 & 14.463 & 8.391 & 14,539 & 8.315 & 7.603 & 4.101 & 3.430 & $4.125^{\circ}$ & 3,406 & 112.921 & 70.381 & 42.540 & 73.984 & 38.937 & 26,029 & 15.769 & 10.260 & 15.444 & 10.585 \\
\hline 36 & 1271.6 & 24.811 & 14.802 & 10.009 & 14.879 & 9.932 & 11.757 & 4.197 & 7.560 & 4.222 & 7.535 & 125.223 & 72.030 & 53.193 & 75.711 & 49.512 & $-27,640$ & 16.139 & 11.503 & 15.806 & 11.834 \\
\hline 37 & 1265.3 & 22.787 & 14.729 & 8,058 & 14.805 & 7.982 & 11.892 & 4.176 & 7.716 & 4.201 & 7.691 & 112.800 & 71.643 & 41.127 & 75.336 & 37.464 & 28.025 & 16.057 & 11.968 & 15.727 & 12.298 \\
\hline 38 & 1279.8 & 25.730 & 14.898 & 10.837 & 14.975 & 10.760 & 12.794 & 4.224 & 8,570 & 4.249 & 8545 & 130.373 & 72.488 & 57.885 & 76.199 & 54.174 & 28.584 & 16.241 & 12.343 & 15.908 & 12.676 \\
\hline 39 & 1303.9 & 25.820 & 15.177 & 10.643 & 15.257 & 10.563 & 12.820 & 4,303 & 8.517 & 4.329 & 8.491 & 130.880 & 73.857 & 57.023 & 77.634 & 53.246 & 28.600 & 16549 & 12.053 & 10.208 & 12.392 \\
\hline 40 & 1323.0 & 25.771 & 15.400 & 10.371 & 15.479 & 10.292 & 11,613 & 4.366 & 7.247 & 4.392 & 7.221 & 124.886 & 74.935 & 49.951 & 78.771 & 46.115 & 29.254 & 16.78 .9 & 12,465 & 16.444 & 12.810 \\
\hline 4 & 1349.3 & 27.921 & 15.707 & 12.214 & 15787 & 1.2 .134 & $-12,157$ & 4.453 & 7.704 & 4.480 & 7.677 & 136.043 & 76.432 & 59.611 & 80.337 & 55.706 & 30.290 & $17 .+22$ & 13.168 & 16.772 & $1.3,518$ \\
\hline 42 & 1379.1 & $28.6,0$ & 16.052 & 12,558 & 16.135 & 12.475 & 12.400 & 4.551 & 7.849 & 4.579 & 7.821 & 139.740 & 78,113 & 61.627 & 82.112 & 07.628 & $=30.790$ & 17.501 & 13.289 & 17.141 & 13.649 \\
\hline 43 & 1399.1 & 29,975 & 16.286 & 13.689 & 16.370 & 13.605 & 5.388 & 4.617 & 0.771 & 4.645 & 0.743 & 157.634 & 79.246 & 78.388 & 83,302 & 74.332 & 33.309 & 17.754 & 15.555 & 17.490 & 1.5 .819 \\
\hline 44 & 1424.9 & 31.970 & 16.585 & $15,385^{\circ}$ & 16.672 & 15.298 & 5,420 & 4.702 & 0.718 & 4.731 & 0,689 & 169,360 & 80.406 & 88.654 & 8.839 & 84.521 & 35.060 & 18.082 & 16.978 & 17.710 & 17.350 \\
\hline 45 & 1453.0 & 32.441 & 16.913 & 15.528 & 17.000 & $15: 441$ & 5.469 & 4.793 & 0.674 & 4.824 & 0.645 & 171.626 & 82.300 & 89.326 & 86.512 & 85.114 & 35.698 & 18.439 & 17.259 & 18.060 & 17.638 \\
\hline 46 & 1481.1 & 31.199 & 17.240 & 13.959 & 17.330 & 13.869 & 5.025 & 4.887 & 0.138 & 4.917 & 0.108 & 163.826 & 83.886 & 79.940 & $88.185^{\circ}$ & 75.641 & 35387 & 18.794 & 16.593 & 18.409 & 10.978 \\
\hline 47 & 1488.6 & 29.138 & 17.327 & 11.811 & 17.417 & 11.721 & 4.298 & 4.912 & -0.614 & 4.942 & -0.644 & 150.885 & 84.315 & 66.570 & 88.631 & 62.254 & 34.873 & 18.890 & 15983 & 18.502 & $|6.37|$ \\
\hline 48 & 1472.3 & 26.663 & 17.138 & 19.525 & 17.226 & 9.437 & 3.827 & 4.859 & -1.032 & 4888 & -1.061 & 137.767 & 83.391 & 54,376 & 87.661 & 50.106 & 32.186 & .8 .683 & 13.503 & 18.300 & 13.886 \\
\hline 49 & 1480.0 & 22.534 & 17.227 & 5.307 & 17.316 & 5.218 & 3.225 & 4.884 & -1.659 & 4.913 & -1.684 & 116.360 & 83.827 & 32.533 & 88.119 & 28.241 & 26.896 & 18.780 & 8.116 & 18.395 & 8.501 \\
\hline 50 & 1456.4 & 21.868 & 16.953 & $4.913^{\circ}$ & 17.041 & 4.827 & 3.048 & 4.807 & -1.759 & 4.836 & -1.788 & 113.295 & 82.490 & 30.805 & -86.714 & 26.581 & 25.290 & 18.482 & 6.808 & 18.103 & 7.187 \\
\hline 51 & 1440.2 & $24,3,0$ & 16.764 & 7.546 & 16.851 & 7.459 & 4.180 & 4.753 & -0.573 & 4.782 & -0.602 & 134.220 & 81.572 & 52.648 & 85.750 & 48.470 & 22.400 & 18.276 & 4.124 & $-17,901$ & 4.499 \\
\hline 52 & 1462.9 & 28.000 & 17.029 & 10.971 & 17.117 & 10.883 & .4 .740 & 4,828 & $-0.088 t$ & 4.857 & -0.117 & 148.340 & 82.860 & 65.480 & 87.101 & 61.239 & 30.690 & 18.564 & 12.126 & 18.183 & 12.507 \\
\hline 53 & 1.487 .9 & 28.963 & 17.319 & 11.644 & 17.409 & 11.554 & 4,746 & 4.910 & -0.164 & 4,940 & $-0,194$ & 152.590 & 84.274 & 68.316 & 88.589 & 64.001 & 32.491 & 18.881 & 13.610 & 18.482 & 14.009 \\
\hline 54 & 1507.7 & 30.640 & 17.550 & 13.090 & 17,640 & 13.000 & 7.840 & $4.975^{\circ}$ & 2.865 & 5.005 & 2.835 & 156.420 & 85.996 & 71.324 & 89.768 & 68.952 & 32.080 & 19.132 & 12.948 & 18.740 & 13.349 \\
\hline 55 & 1536.3 & 31.610 & 17.883 & 13.727 & 17.975 & 13,635 & 8.060 & 5.070 & 2.990 & 5.101 & 2.959 & 161.190 & .87 .018 & 74.172 & -91.471 & 69.719 & 33.570 & 19.495 & 14.075 & 19.095 & $14.470^{\circ}$ \\
\hline 56 & 1550.9 & 31.990 & 18.052 & 13.938 & 18.146 & 13.844 & 8.150 & 5.118 & 3.032 & 5.149 & 3.001 & 1.69 .070 & 87.843 & 75.227 & 92.341 & 70,729 & 33.990 & 19.680 & 14,310 & 19.277 & 14.713 \\
\hline 57 & 1574.7 & 32.350 & 18.331 & 14.019 & 3) 18.424 & 13.926 & $\delta .240$ & 5.197 & 3.043 & 5.228 & $3.0 \quad 12$ & 464.910 & 89.191 & 75.719 & 93.758 & 41.152 & 34.360 & 19.983 & 14.377 & 19.579 & 14.787 \\
\hline
\end{tabular}


out.

Feriad Protion Requint Protein Requine- Rsotein

T58 1589.443230018 .502113 .79818 .599

$58 / 589.4 \quad 32.300 \quad 18.502 \quad 13.798 \quad 18.599 \mid 13.701$

\begin{tabular}{l|l|l|l|l|l|l|l|l|l|l|l|l}
59 & 1608.1 & 33.938 & 18.720 & 10.218 & 18.815 & 5.123
\end{tabular}

$601643.7 \quad 31.605,9.133,2.472,9.232,2.373$

$61 \quad 1644.3 \quad 28.306 \quad 19.141 \quad 49.165 \quad 19.2 .40 \quad 9.066$

$\begin{array}{llllllllll}62 & 1660.5 & 29.872 & 19.829 & 10.543 & 19.429 & 10.443\end{array}$

$\begin{array}{llllllllll}63 & 1683.0 & 29.275 & 19.590 & 9.685 & 19.691 & 9.584\end{array}$

$\begin{array}{lllllllll}64 & 1707.8 & 28.561 & 19.878 & 8.683 & 19.981 & 8.580\end{array}$

$\begin{array}{lllllllll}65 & 1710.9 & 29.125 & 19.915 & 9.210 & 20.019 & 9.106\end{array}$

\begin{tabular}{l|llllllll}
66 & 1.720 .6 & 27.590 & 20.027 & 7.563 & 20.132 & 7.458
\end{tabular}

\begin{tabular}{llllll|l|l|l|l|l}
67 & 1696.6 & 28.169 & 19.746 & 8.423 & 1.9 .851 & 8.318
\end{tabular}

$\begin{array}{lllllllll}68 & 1718.2 & 25.730 & 20.001 & 5.729 & 20.103 & 5.627\end{array}$

$69 \quad 1749,1 \quad 27.034 \quad 20.360 \quad 6.67420 .465 \quad 6.569$

$\begin{array}{llllllllll}70 & 1746.8 & 27.880 & 20.334 & 7.546 & 20.439 & 7.441\end{array}$

$71 \quad 1761.028 .33020 .499: 7.83120 .604 \quad 7.726$

\begin{tabular}{lllllll|l}
72 & 1797.4 & 20.900 & 14.645 & 6.255 & 14.723 & 6.177
\end{tabular}

Iotal Ybs. 1603.480916 .919686 .561921 .644

Jotal Ks. 727.322
$9.404 \quad 5.307$

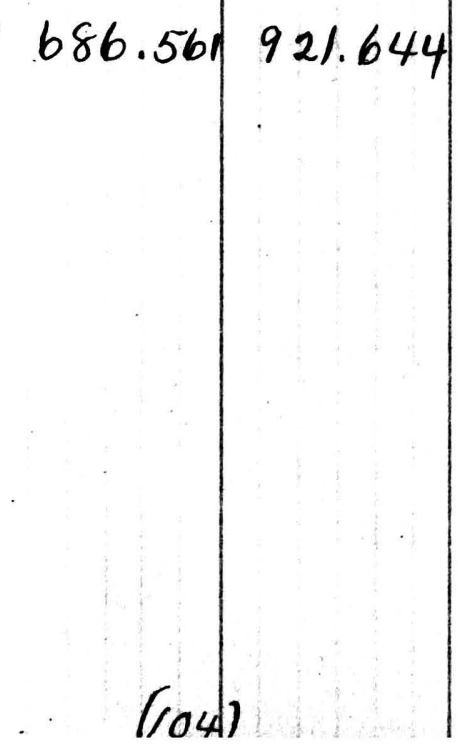

\section{7 at Qequic}

consund nent

$8,370 \quad 5.246$

$8.580 \quad 5.425$

$7.459 \quad 5.426$

8.253

7.951

7.721

8.027

$7.344 \div 5.678$

$7.737 \quad 5599$

$6.929 \quad 5.670$

8.171

8.520

8.570

5.770

5.763

$5,8 / 2$

$\begin{array}{llll}6.177 & 6.300 & 4152\end{array}$

\section{7 at Requin.}

ment.

$3.124 \lcm{5.277}$

4.0975339

3.15555 .457

2.0335 .459

$2.7735 .5 / 3$

$\begin{array}{llll}5554 & 2.397 & 5.5 .88\end{array}$

$2.085^{\circ} 5.670$

2.3815 .680

1.6665 .711

$2.38(5.6311$

1.2595 .704

$2.401 \quad 5.807$

$2.755 \cdot 5.800$

2.7585 .846

$2,148 \quad 4.171$

$309.274 \quad 204.101$

\section{$7 a t$}

309316583090.02475 .80694 .633

$\begin{array}{lllllllllll}50.143991 .083 & 89.060 & 90.746 & 84.397 & 30.523 & 20.407 & 0.116 & 19.989 & 0.534\end{array}$

\begin{tabular}{ll|l|l|l|l|l|l|l|l|l|l|l|}
$3.123 / 65.463$ & 93.100 & 72.363 & 97.866 & 67.597 & 29.745 & 20.858 & 8.887 & 20.431 & 9.314
\end{tabular}

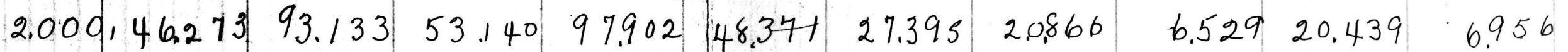

$\begin{array}{llllllllllll}2.740157 .523 & 94.051 & 63.473 & 98.866 & 58.657 & 27.842 & 21.072 & 6.770 & 20.640 & 7.202\end{array}$

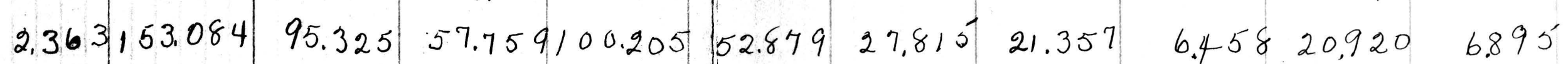

\begin{tabular}{ll|l|l|l|l|l|l|l|l|l|l|l|l|l}
2.051 & 150.033 & 96.730 & 53.303 & 101.682 & 48.351 & 27.139 & 21.642 & 5.467 & 21.227 & 5.912
\end{tabular}

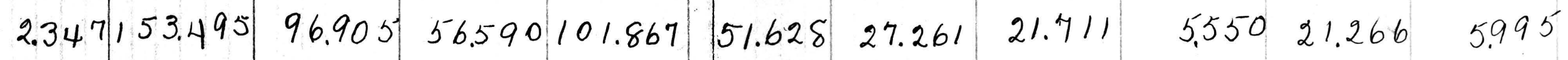

$\begin{array}{llllllllllll}1.633 & 145.423 & 97.455 & 47.968 & 102.445 & 42.978 & 25.985 & 21.834 & 4.151 & 21.387 & 4.598\end{array}$

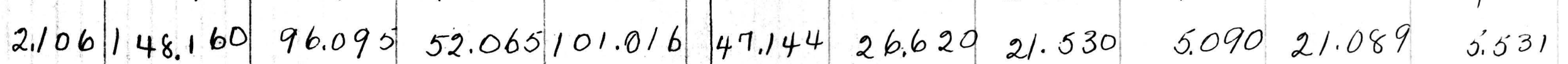

\begin{tabular}{ll|l|l|l|l|l|l|l|l|l}
1.225 & 34.960 & 97.319 & 37.641 & 102302 & 32.658 & 26.550 & 21.803 & 3.747 & 21.357 & 4.193
\end{tabular}

\begin{tabular}{ll|l|l|l|l|l|l|l|l|l|l|l|l|l}
$2.364 / 41.672$ & 99.069 & 42.603 & 04.141 & 37.531 & 25.157 & 22.197 & 2.960 & 21.741 & 3.416
\end{tabular}

$2.720147 .450 \quad 98.939 \quad 48.511 \quad 104.004 \quad 43.446 .24 .760 \quad 22.167 \quad 2.593 \quad 21.713 \quad 3.047$

$2.724 / 48.170 \quad 99.743 \quad 48.427 \quad 104.850 \quad 43.320 \quad 26.630 \quad 22.348 \quad 428221.889 \quad 4.741$

\begin{tabular}{ll|l|l|l|l|l|l|l|l|l|l|l|l|l|}
2.123 & 108.880 & 71.263 & 37.617 & 74.912 & 33,968 & 20.150 & 15.966 & 4.184 & 15.639 & 4.511
\end{tabular}

261.496

$188.4728132 .5814461 .5663671 .015^{\circ} 4689.779$

80.4893688 .857

1561.621743 .239

299.100 


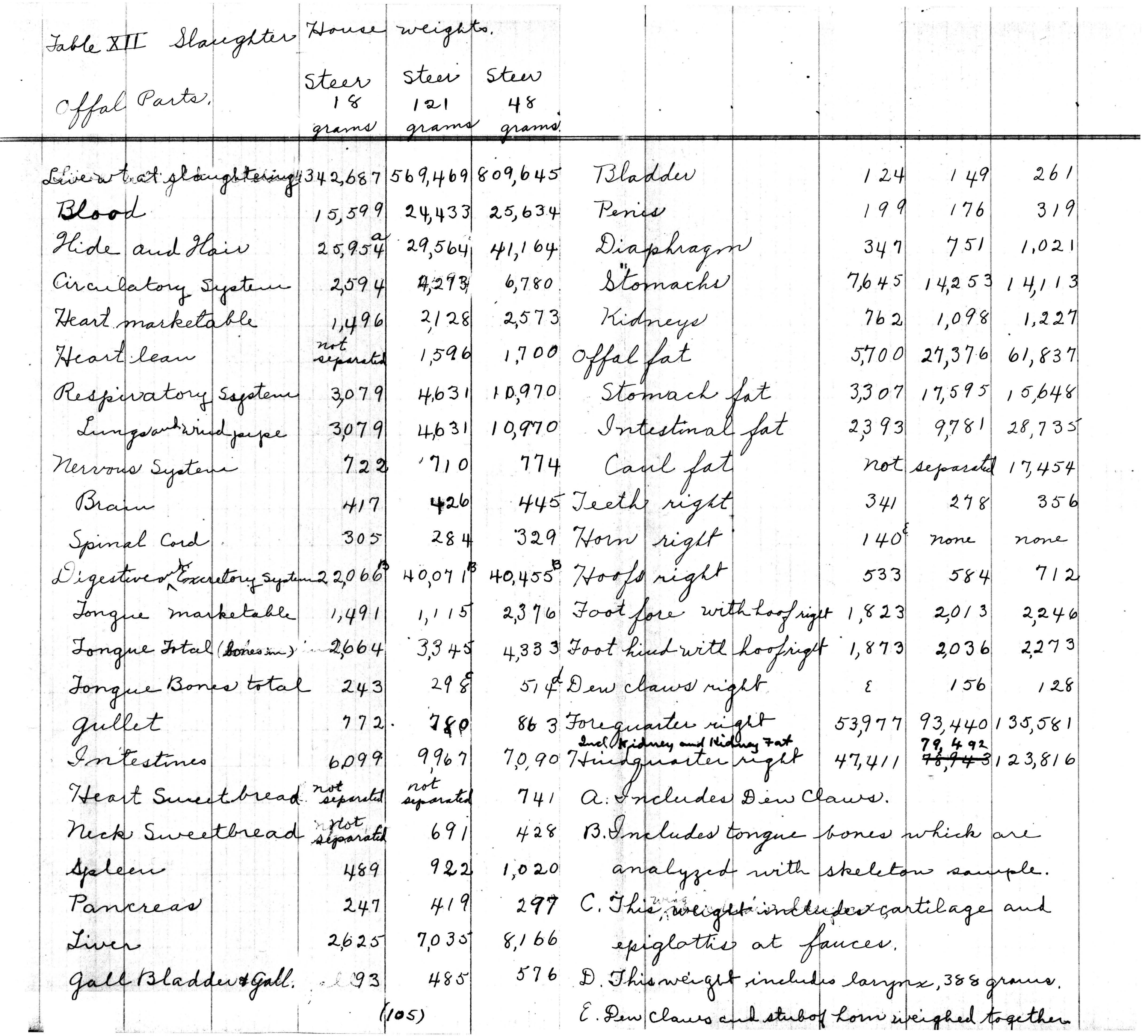




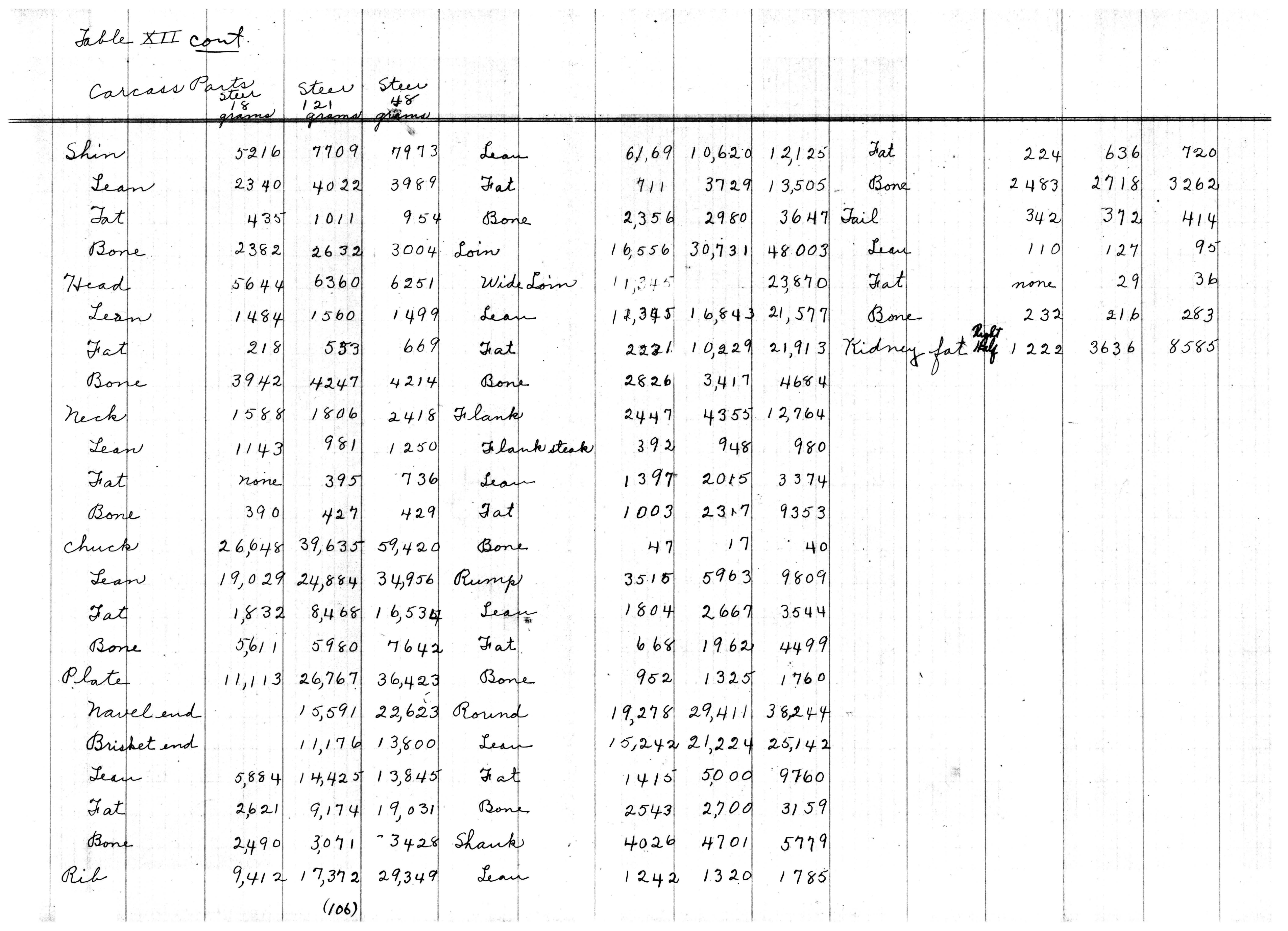




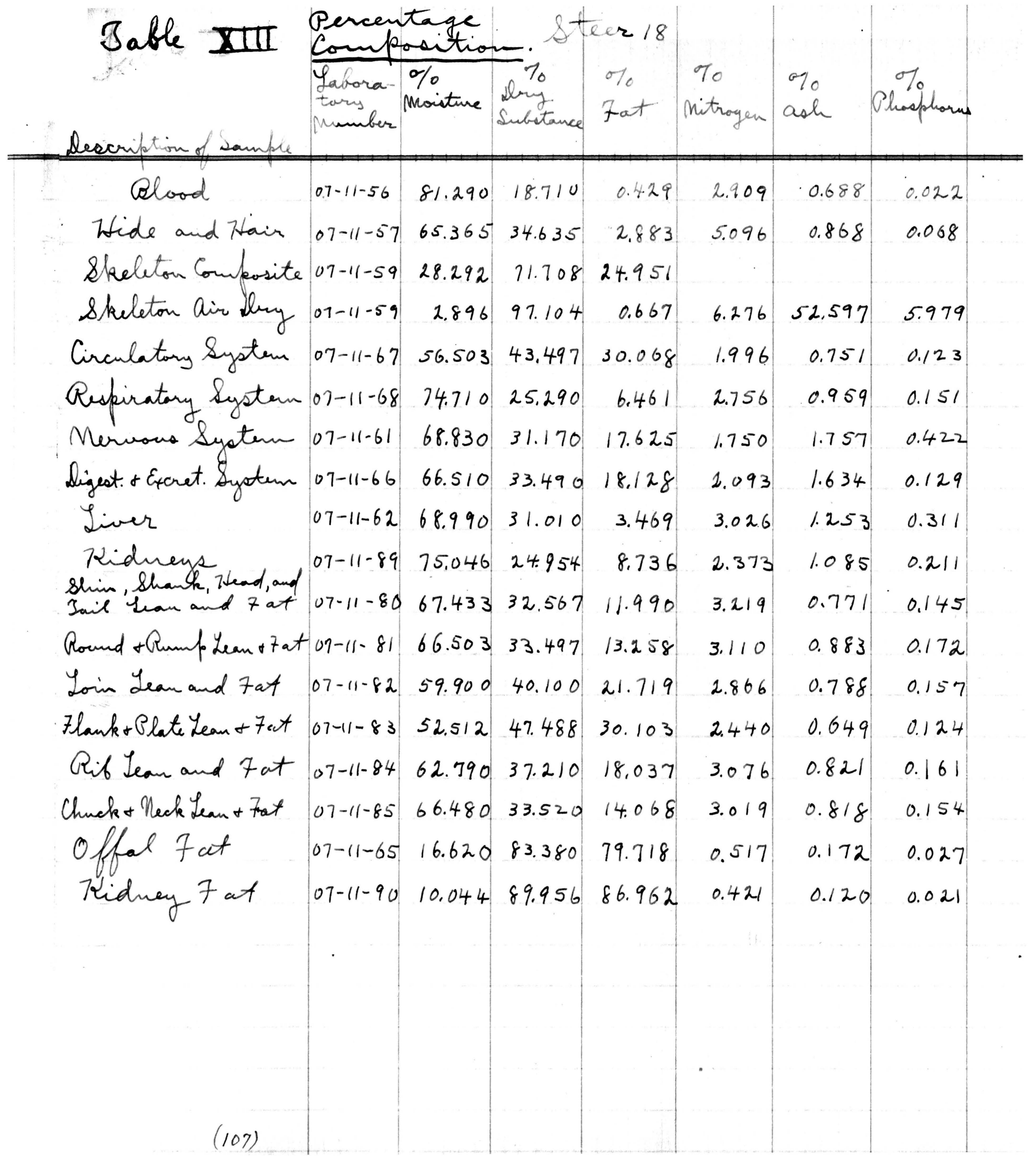




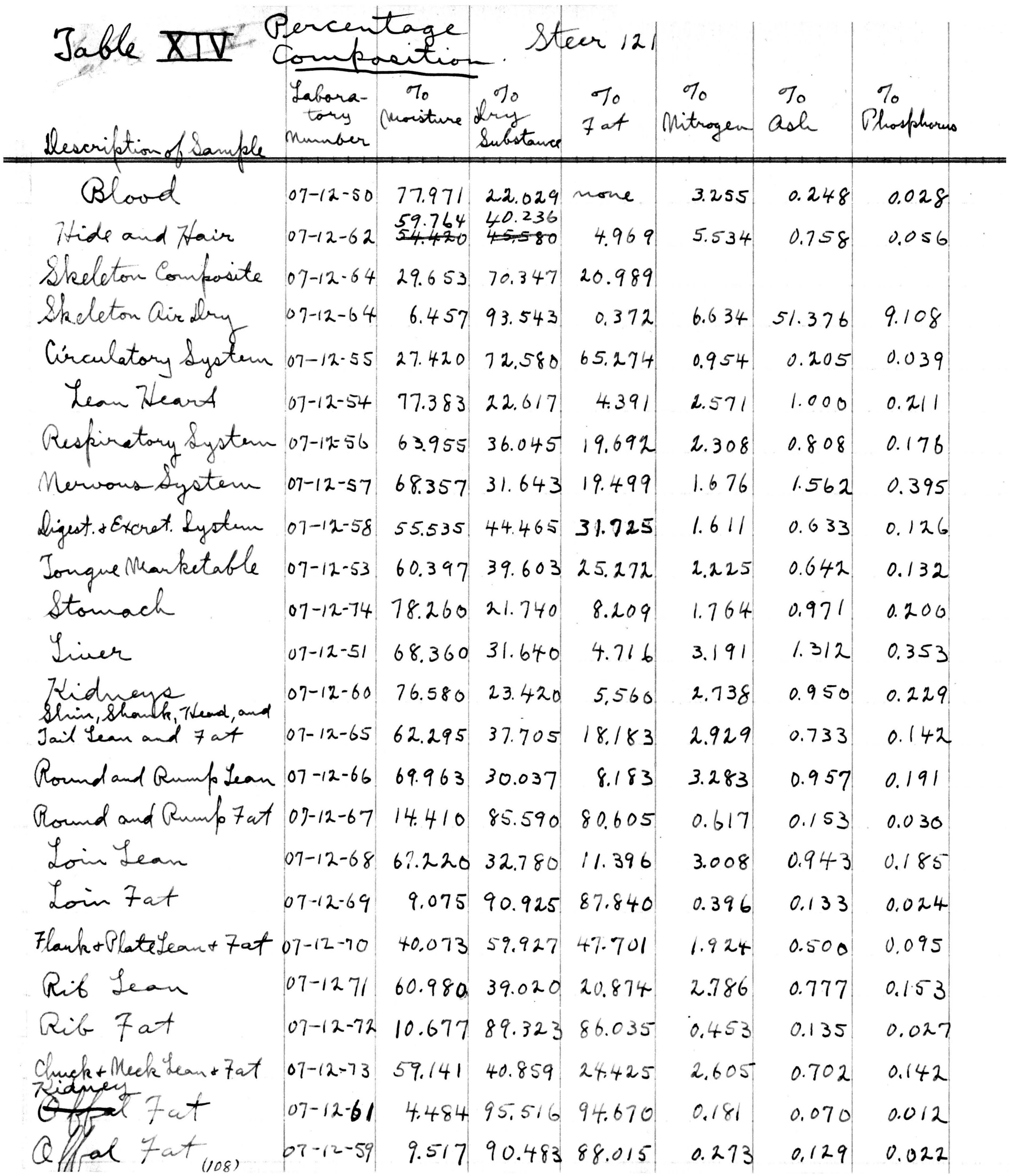




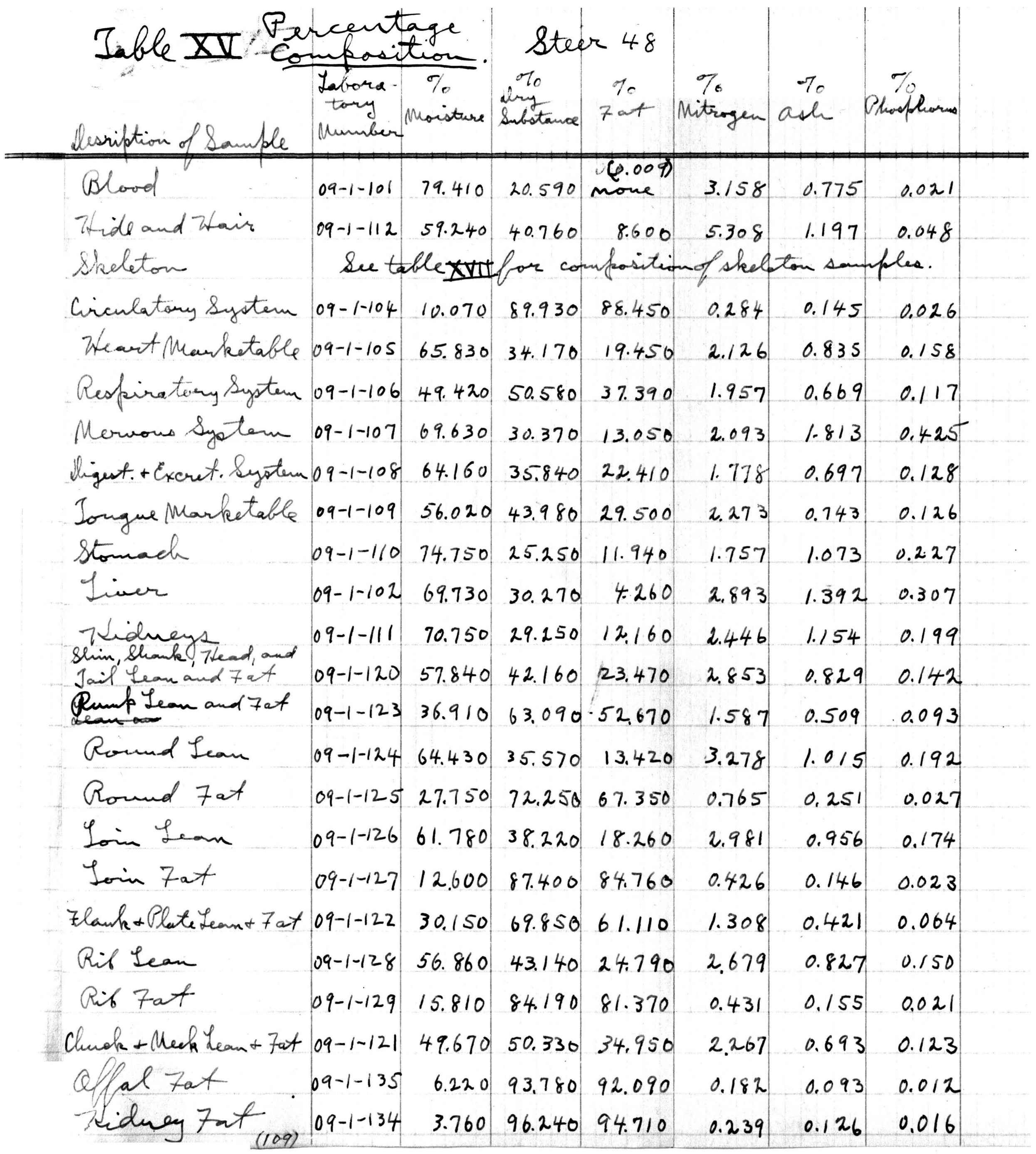




\section{Jable XVI Compasited Systems.}

Ster 18

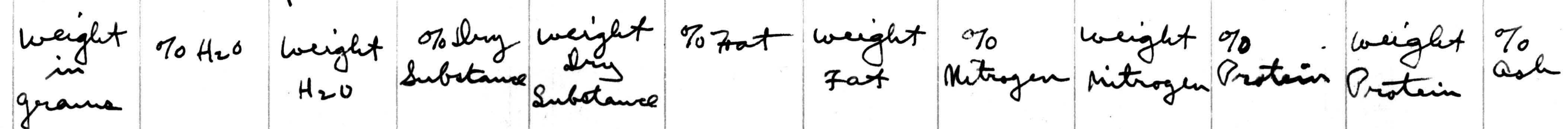

digest. Exachet. System Part. $18436 \quad 66.51012261 .80 \quad 33.4906174 .20 \quad 18.128 \quad 3342.08$ Y.iver $2625 \quad 68.990 \quad 1811.00 \quad 31.010 \quad 814.00$ 72 inlneys

$\begin{array}{llllll}762 & 75.046 & 571.85 & 24.954 & 190.15\end{array}$ $3.469 \quad 91.06$ $2.093 \quad 385.90$ 3.026 79.43 13.0812411 .60 Ital dligest. + Excret. Saptem $\begin{array}{lllllll}21823 & 67.10614644 .65 & 32.8947178 .35 & 16.037 & 3499.71\end{array}$ Steer 121

Circulatory dystem Past.

$2677 \quad 22.420 \quad 734.03 \quad 72.5801942 .97 \quad 65.2741747 .38$ teart Lean $\begin{array}{llllllll}1596 & 77.3831235 .03 & 22.617 & 360.97 \quad \% 391 \quad 70.08\end{array}$ Iotal linculatary \&ystem $\begin{array}{llll}473 & 46.081 & 1969.06 \quad 53.9192303 .94 \quad 42.5341817 .46\end{array}$ Diget. Exeret. Sy, tem Part

$$
\text { \&tomach }
$$
$5525 \quad 55.5358621 .81 \quad 44.4656903 .19 \quad 31.7254925 .31$

Iongue Marketable $14253 \quad 78.26011154 .40 \quad 21.7403098 .60 \quad 8.2091170 .03$ timer.

Tidnaigr $\begin{array}{llllllll}1862 & 60.397 & 1124.59 & 39.603 & 737.41 & 25.272 & 470.56\end{array}$ $\begin{array}{llllllll}7035 & 68.360 & 4809.13 & 31.64 .02225 .87 & 4.716 & 331.77\end{array}$ $\begin{array}{lllllllll}1098 & 76.580 & 840.85 & 23.420 & 257.15 & 5.560 & 61.05\end{array}$

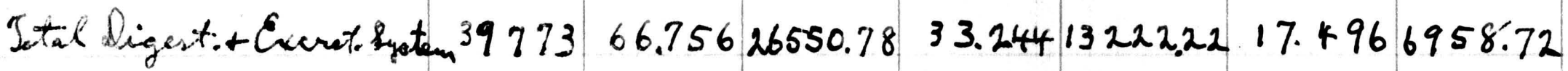
Steer 48

CiculatingsytemPat. 4207 10.070 $423.6489 .9303783 .36 \quad 88.4503721 .09$ Heant marketable $\begin{array}{llllllll}2573 & 65.8301693 .80 & 34.170 & 879.20 & 19.450 & 500.45\end{array}$ Iotal circulatiany \&yotem. $6780 \quad 31.2312117 .44 \quad 68.7694662 .56 \quad 62.265 .42 .21 .54$ Digest. Exant. Eystem Pant 1405964.1609020 .2535 .8405038 .7522 .4103150 .60 Inicer $8166 \quad 69.7305694 .15 \quad 30.2702471 .85 \quad 4.260 \quad 347.90$ stomach $14113 \quad 74.75010849 .4725 .2503563 .53 \quad 11.9401685 .10$

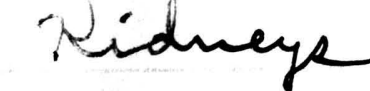
$\begin{array}{lllllllll}1227 & 70.750 & 868.10 & 29.250 & 358.90 & 12.160 & 149.20\end{array}$ Lougue Manketable $\begin{array}{llllllll}2376 & 56.0201331 .03 & 43.980 & 1044.97 & 29.500 & 700.90\end{array}$ Iotul Rigest. Exeret. System $39941 \quad 68.75927463 .00 \quad 31.24112478 .00 \quad 15.1076033 .70$ $\begin{array}{lllll}2.373 & 18.08 & 14.831 & 113.00\end{array}$

$2.215 \quad 483.41 \quad 13.8443021 .10$

0.954

2.571

25.54

$5.960 / 59.63$ $41.03 \quad 16.070 \quad 256.44$

1.558 66.57

$9.738 \quad 416.07$ $1.61 / 250.11 \quad 10.0701563 .19$ $1.764 \quad 251.42 \quad 11.0301571 .38$ $\begin{array}{lllll}2.225 & 41.43 \quad 13.910 & 258.94\end{array}$ $3.191 \quad 224.49 \quad 19.9401403 .06$

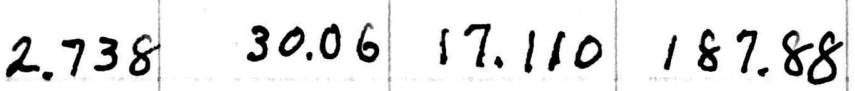
$2.005 \quad 797.51 \quad 12.5314984 .44$

\section{$\begin{array}{llll}0.284 & 11.95 & 1.775 & 74.69\end{array}$} 2.126 54.70 $3.288 \quad 341.88$ 0.983 66.65

$6.144 \quad 4 / 6.57$ $\begin{array}{lllll}1.778 & 249.97 \quad 11.113 & 1562.31\end{array}$ $\begin{array}{llllll}2.893 & 236.24 & 18.081 & 1476.50\end{array}$ $\begin{array}{llllll}1.757 & 247.97 & 1.0 .981 & 1549.81\end{array}$ $\begin{array}{lllll}2.446 & 30.01 & 15.288 & 187.56\end{array}$ $2.273 \quad 54.01 \quad 14.206 \quad 337.56$ $2.049 \quad 818.20 \quad 12.8065113 .75$
1.634301 .24

$1.253 \quad 32.89$

0.129

0.311

1.085

8.27

0.211

23.78

8.16

1.569342 .40 0.154

3.55

$\begin{array}{lll}0.205 & 5.49 & 0.039\end{array}$

1.04

1.000

15.96

0.211

3.37

0.502

21.45

0.103

4.41

0.633

98.27

0.126

19.56

$0.971 \quad 138.40$

0.200

28. 51

$0.642 \quad 11.95$

0. 132

2.46

1.31292 .30

$0.353 \quad 24.83$

$0.950 \quad 10.43$

0.229

2.51

$0.883 \quad 351.35$

$0.196 \quad 77.8 .7$

$\begin{array}{llll}0.145 & 6.10 \quad 0.026 \quad & 1.09\end{array}$

0.835

21.48

0.158 .

4.07

0.40727 .58

0.096

5.16

$0.697 \quad 97.99$

$0.128 \quad 18.00$

$1.392 \quad 113.67$

$0.307 \quad 25.07$

1.073 is 1.43

$0.227 \quad 32.04$

$1.154 \quad 14.16$

0.199

2.44

$0.743 \quad 17.65$

0.126

2.99

0.989394 .90

0.20280 .54 


\section{Sable XVII}

Comporition of Boves on ainding, bly, and 7resh Bases.

Stex Lample Mumber

18 Composite o7-11-59 $28.292 \quad 24.951 \quad 53.243 \quad 46.757$

$\begin{array}{lllllll}2.896 & 97.104 & 0.667 & 0.687 & 0.321\end{array}$

6.276

6.463

$3.022 \quad 5.979$

6.157

$2.879 \quad 52597$
Rone

121 Comporite 07-12-64 29.653 $20.989 \quad 50.64249 .358$

$\begin{array}{llllllll}48 & \text { Fect, thead t Iail o9-1113 } & 37.050 & 11.519 & 48.569 & 51.431\end{array}$

48 Shim thank o9-1142 $20.710 \quad 24.344 \quad 45.054 \quad 54.946$

$\begin{array}{lllllll}6.457 & 93.543 & 0.371 & 0.397 & 0.196\end{array}$

48 Round o9-1114 23.160 32.479 55.639 44.361

48 Rump 09-1-115 26.290 $35.688 \quad 61.978 \quad 38.022$

48 Join

\begin{tabular}{ll|l|l|l|l|l|l|l|l|l|l|l|}
$09-1-116$ & 21.550 & 29.603 & 51.153 & 48.847
\end{tabular}

48 chuckt Mechoi-1-117 $27.780 \quad 18.655 \quad 46.435 \quad 53.565$

48 Tlanks Plateog-1-118 $37.730 \quad 19.561 \quad 57.297 \quad 42.703$

7.84592 .155 mone - $\quad 5.370 \quad 5.827 \quad 3.202$

$11.234 \quad 6.173$

7.28092 .720 mone - $-4.440 \quad 4.789 \quad 2.124 \quad 4.316 \quad 5.020$

8.01591 .985 mone $-5.550 \quad 6.034 \quad 2.294$

$10.233 \quad 3.891$

7.34892 .652 mone $-5.350 \quad 5.774 \quad 2.820$

$9.836 \quad 4.805$

7.95592 .045 mone - $-6.060 \quad 6.584 \quad 3.527$

$9.470 \quad 5.073$

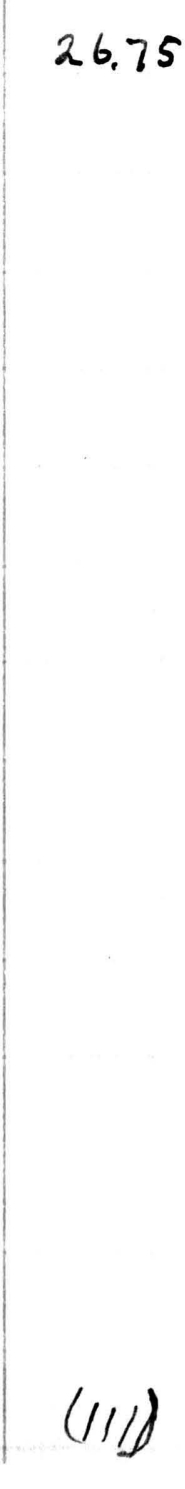

$6.420 \quad 7.022 \quad 2.999$

$8.834 \quad 3.772$

$9.867 \quad 5.416$

$54.922 \quad 27.108 \quad 21.185$

$4.7 .660 \quad 24.510$ b

$60.130,33,040$

$61.020 \quad 27.070$

$54.300 \quad 20.650$

$53.420 \quad 26.090$

$51.400 \quad 27.530$

$47.360 \quad 20.220$

$53.580 \quad 29.410$

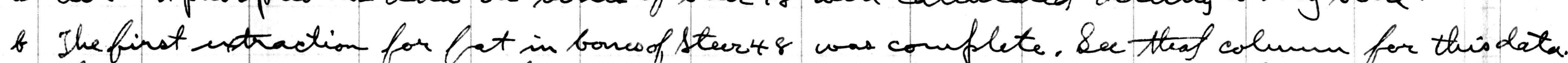

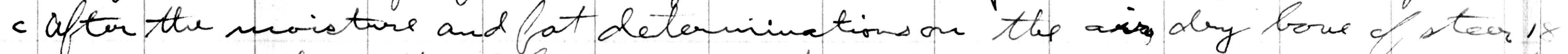
the mice destroyed all but one sample, His one sample was analyget fas.

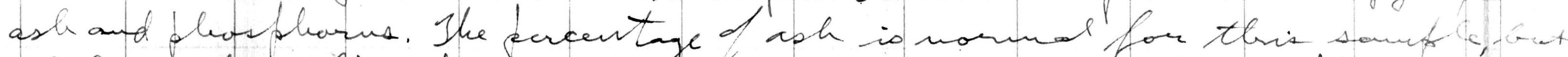

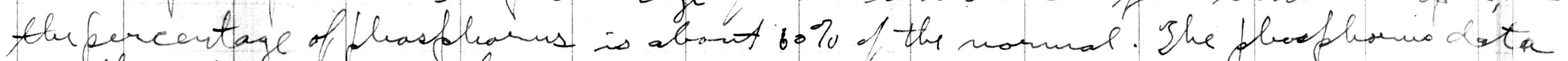
is therefore questionable and panth witiates all shosflemus hata which includer the bours. 
Table XVIII. Ster 18Lean.

weight \% weight a \% weight \% weight. $\%$ weight \%o weight \% weight \%o weight

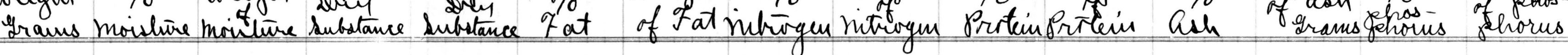

\begin{tabular}{|c|c|c|c|c|c|c|c|c|c|c|c|c|c|c|}
\hline Lean & of shu & 4680 & 67.4333155 .86 & 32.567 & & & 3.219 & 150.65 & & & & & & \\
\hline " & - Sla & 11768 & $52.5 / 2 \quad 6179.61$ & 47.488 & 80.103 & & 2.440 & 287.14 & & & .649 & & .124 & 14,5 \\
\hline " " & C & 5058 & 6.48025300 & $33.520 / 2757$ & 1.068 & & & & & & .818 & & & 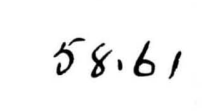 \\
\hline$"$ & $\cdot h$ & 2286 & $66.480 \quad 1519.73$ & $520 \quad 766.27$ & 1.068 & & & 69.0 & 18.869 & & 818 & & & \\
\hline ." & & 12338 & 62.790 & $37.210 \quad 4590.97$ & 18.037 & & & & 19.225 & & .821 & & (190 & \\
\hline & If Poreq & 69130 & 63.50849903 .19 & 36.49225126 .8 & 17.3671 & & 944 & & 18.400 & 127 & 0.787 & 48.75 & 0.150 & \\
\hline " & e & 2484 & $67.433 \quad 1675.04$ & $32.567 \quad 808.96$ & 11.990 & & 219 & 79.96 & $20.1 / 9$ & & 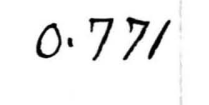 & & 0.145 & 3.60 \\
\hline . " & Rou & 30484 & 66.50320272 .77 & 33.49710211 .2 & & & 䅦 & 948.05 & 19.438 & & 0.883 & & & 2,45 \\
\hline " " & ren & 3608 & $66.503 \quad 2399.43$ & $33.497 \quad 1208.57$ & 13.258 & & 8.110 & 112.9 & 19,438 & & 3 & & & 6.2 \\
\hline " & & 22690 & 59.90013591 .31 & 40.100 & 1.719 & 4928 & 2.866 & 650.5 & 17.919 & 4064 & 0.788 & & & $n$ \\
\hline ". & & 2794 & $52.512 / 46$ & $8 \quad 1326.81$ & & 841.08 & 2.440 & & 15.250 & & & & & \\
\hline ." & Xuridas & 62060 & 69.496394 & 36.5042265426 & 17.0591 & & 2.995 & & 18.719 & & & & & 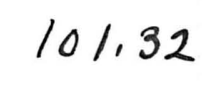 \\
\hline$" \quad "$ & cases & 131190 & 63.583833 & 36.49747881 .07 & 17.22 & & 2.968 & & 18.550 & & & & & 年 \\
\hline " " & & (1) & 67.433 & $32.567 \quad 966.59$ & 11.990 & & 3.219 & $95: 54$ & & 597.13 & & & & $r+5$ \\
\hline " & & & $67.433 \quad 148.35$ & $67 \quad 71.65$ & 11.990 & & & & 20.119 & & 0.771 & & 0.143 & 0.13 \\
\hline & & 134378 & 63.59685408 .69 & 36.40448919 .31 & & 973.96 & .974 & 399.6 .60 & & 24978.75 & 0.88 & & 0.156 & 209.3 \\
\hline
\end{tabular}




\section{Table XIX}

Steer 20. 18. Fat

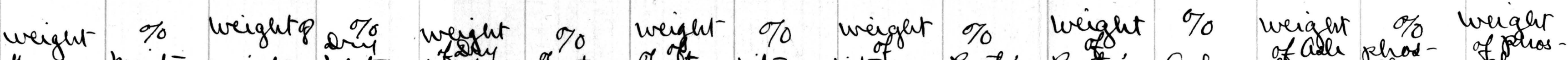

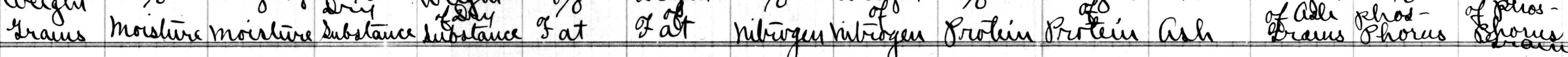

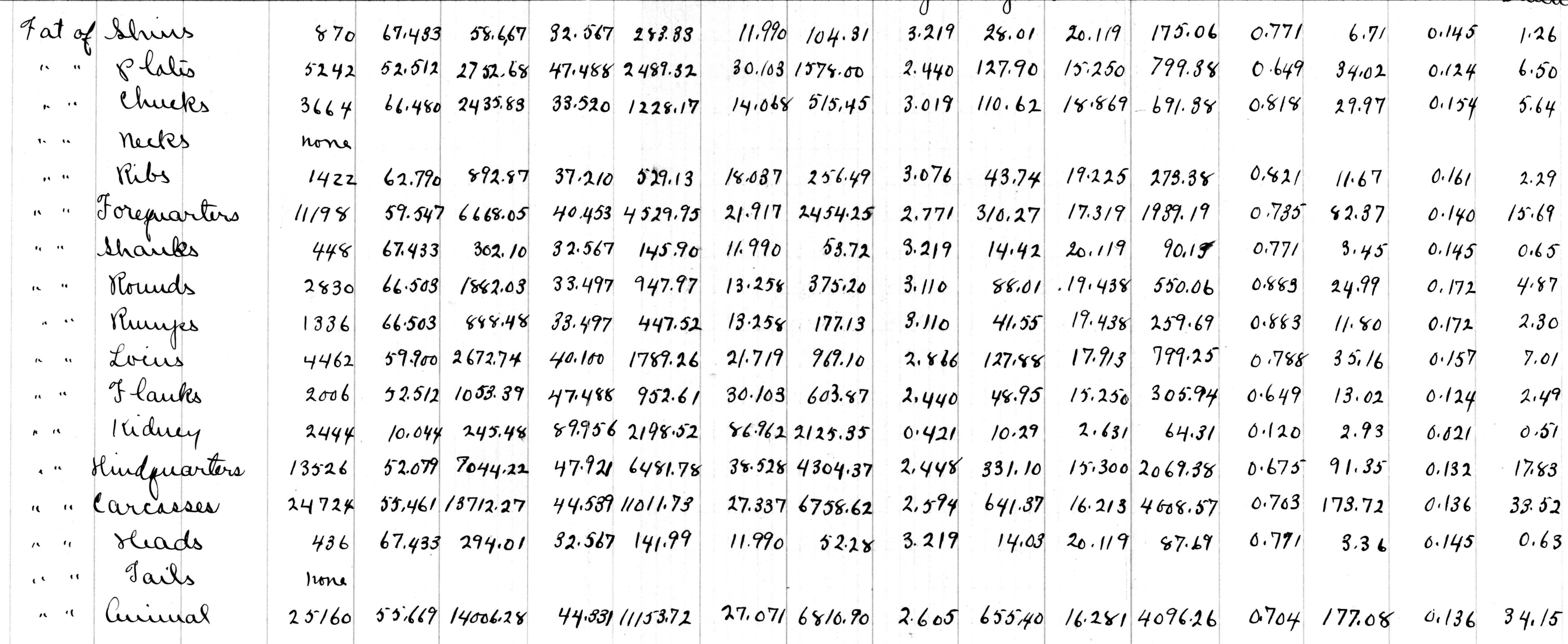


Iable XX.

Steer no.18 Skeleton

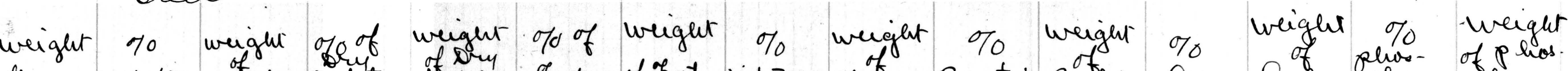

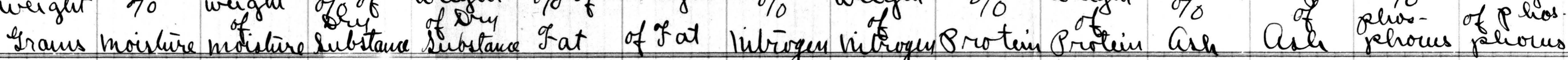

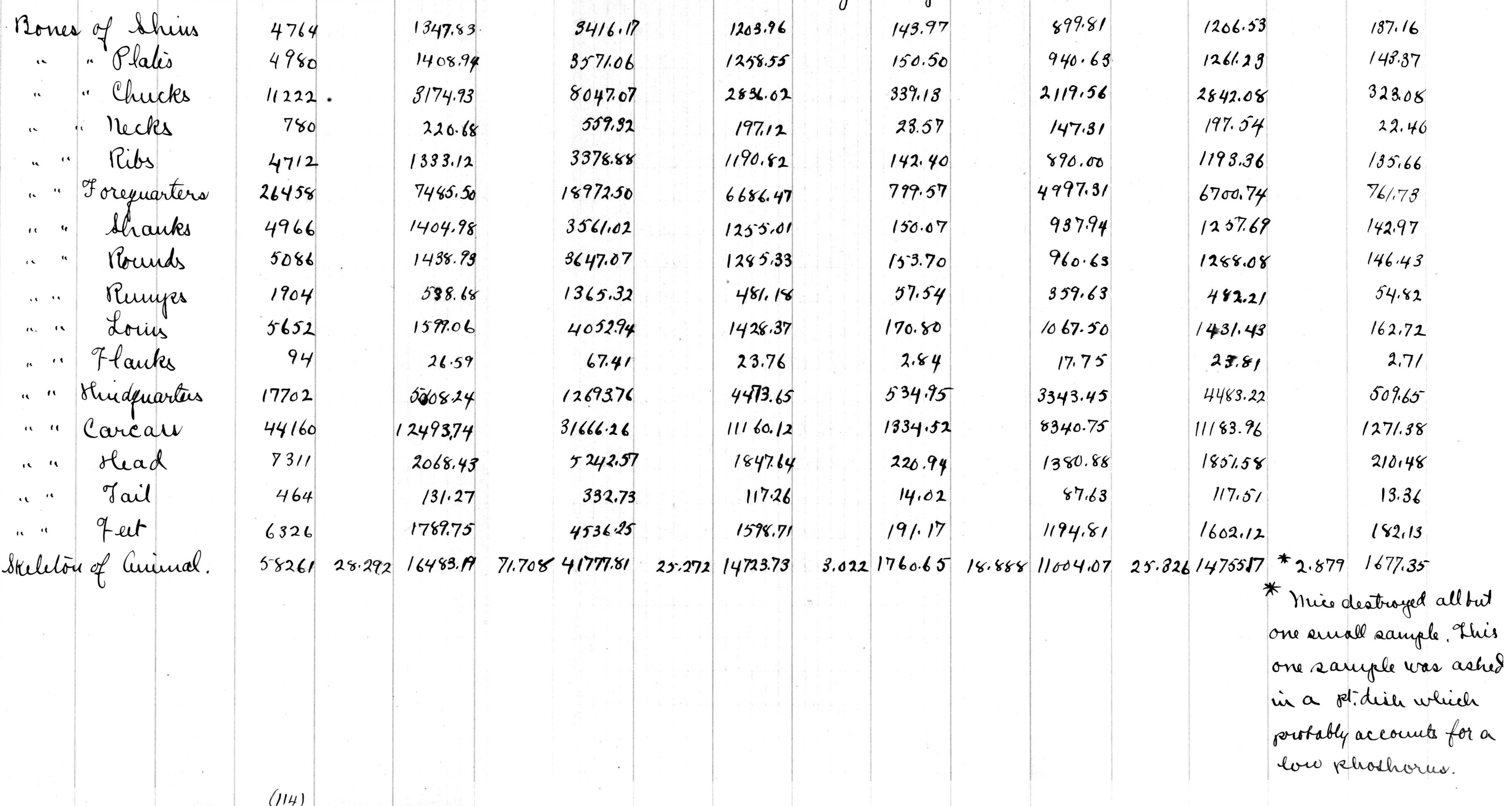




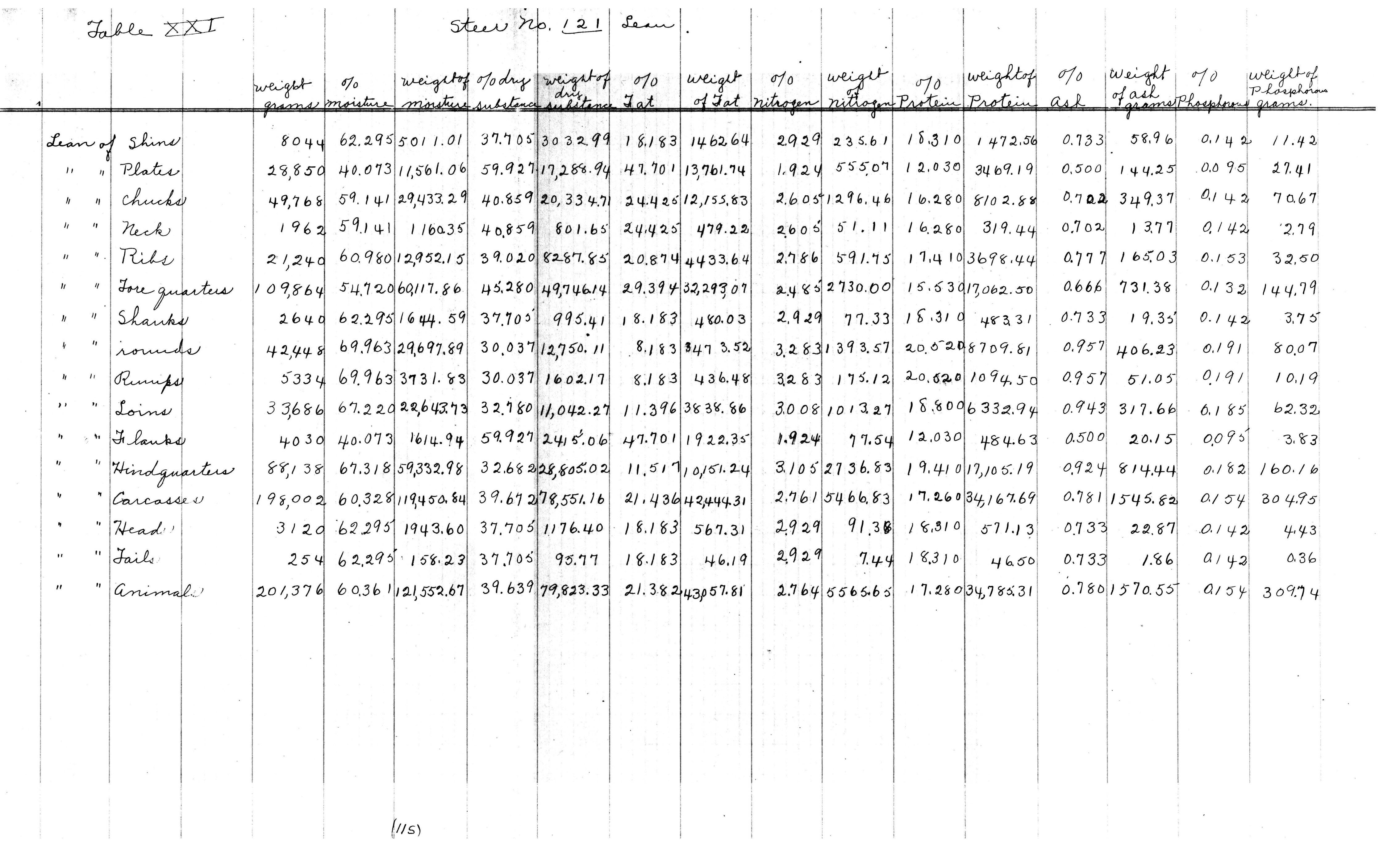


Yable XXII

Steer 120.121 Fat.

weight 010 weight of 70 dry weight of 010

gean

That of shins

" plates

"chucks

" necks

"ribs

"Forequarters

"shauks.

1 rounds

" rumps

" loins

" flauts

" kidneys

" hindquartes

" carcasse.

head

tail.

Animal
$2022 \quad 62.295 / 259.60 \quad 37.705 \quad 762.40 \quad 18.183 \quad 367.66$

\begin{tabular}{lllll|l|l|l|l|l|l|}
18,348 & 40.0737352 .59 & 59.92710995 .41 & 47.701 & 8752.18
\end{tabular}

$\begin{array}{llllllll}16,936 & 59.141 / 0,016.12 & 40.859 & 6919.88 & 24.425 & 4136.62\end{array}$

$\begin{array}{llllllllll}790 & 59.141 & 467.21 & 40.859 & 322.79 & 24.425 & 192.96\end{array}$

\begin{tabular}{lllll|l|l|l|l|}
7.458 & 1 & 0.677 & 796.29 & 89.323 & 6661.71 & 86.035 & 6416.49
\end{tabular}

\begin{tabular}{lllll|l|l|l|l|l|l|l|}
45,554 & 43.66 .6 & $19,891.81$ & 56.334 & $25,662.19$ & 43.610 & $19,865.91$
\end{tabular}

$\begin{array}{lllllllll}1272 & 62.295 & 792.39 & 37.705 & 479.61 & 18.183 & 231.29\end{array}$

$\begin{array}{llllllll}10,000 & 14.4101441 .00 & 85.590 & 8559.00 & 80.605 & 8060.50\end{array}$

$\begin{array}{llllllllll}3924 & 14.410 & 565.45 & 85.590 & 3358.55 & 80.605 & 3162.94\end{array}$

$20,458 \quad 9.0751856 .56 \quad 90.925 \mid 18,601.44 \quad 87.84017,970.31$

$4634 \quad 40.0731856 .98 \quad 59.9272777 .02 \quad 47.7012210 .46$

$\begin{array}{lllllll}7272 & 4.484 & 326.08 & 95.516 & 6945.92 & 94.6706884 .40\end{array}$

\begin{tabular}{ll|l|l|l|l|l|l|l}
$47,560 \quad 14.378$ & 6838.46 & $85.62240,721.54$ & $80.99238,519.90$
\end{tabular}

$93,114 \quad 28.70726,730,28 \quad 71.29366,383: 73 \quad 62.701 \quad 58,385.81$

$\begin{array}{llllllll}1,106 & 62.295 & 688.98 & 37.705 & 417.02 & 18.183 & 201.10\end{array}$

$\begin{array}{lllllllll}58 & 62.295 & 36.13 & 37.705 & 21.87 & 18.183 & 10.55\end{array}$

$\begin{array}{lllllll}94,278 & 29.12227,455.39 & 70.878 & 66,822.62 & 62.15458,597.46\end{array}$
0

weight 010

weight ofo

weiget of

weight

ash Plosphouptosphor

\begin{tabular}{r|r|r|r|r|r|r|r}
\hline 2.929 & 59.22 & 18.31 & 370.13 & 0.733 & 14.82 & 0.142 & 2.87 \\
1.924 & 353.02 & 12.03 & 2206.38 & 0.500 & 91.74 & 0.095 & 17.43 \\
\hline 2.605 & 441.18 & 16.28 & 2757.38 & 0.702 & 118.89 & 0.142 & 24.05 \\
\hline 2.605 & 20.58 & 16.28 & 128.63 & 0.702 & 5.55 & 0.142 & 1.12 \\
0.453 & 33.78 & 2.83 & 211.13 & 0.135 & 10.07 & 0.027 & 2.01 \\
1.993 & 907.78 & 12.4565673 .65 & 0.529 & 241.07 & 0.104 & 47.48 \\
\hline 2.929 & 37.26 & 18.31 & 232.87 & 0.733 & 9.32 & 0.142 & 1.81 \\
0.617 & 61.70 & 3.86 & 385.63 & 0.153 & 15.30 & 0.030 & 3.00 \\
0.617 & 24.21 & 3.86 & 151.31 & 0.153 & 6.00 & 0.030 & 1.18 \\
0.396 & 81.01 & 2.48 & 506.31 & 0.133 & 27.21 & 0.024 & 4.91 \\
1.924 & 89.16 & 12.03 & 557.25 & 0.500 & 23.17 & 0.095 & 4.40 \\
0.181 & 13.16 & 1.13 & 82.25 & 0.070 & 5.09 & 0.012 & .87 \\
.644 & 306.50 & 4.0251915 .62 & 0.181 & 86.09 & 0.034 & 16.17 \\
1.304 & 1214.28 & 8.150 & 7589.27 & 0.351 & 327.16 & 0.068 & 63.65 \\
2.929 & 32.39 & 18.31 & 202.44 & 0.733 & 8.11 & 0.142 & 1.57 \\
2.929 & 1.70 & 18.31 & 10.63 & 0.733 & .43 & 0.142 & 08 \\
1.3241248 .37 & 8.2757802 .34 & 0.356 & 335.70 & 0.069 & 65.30
\end{tabular}




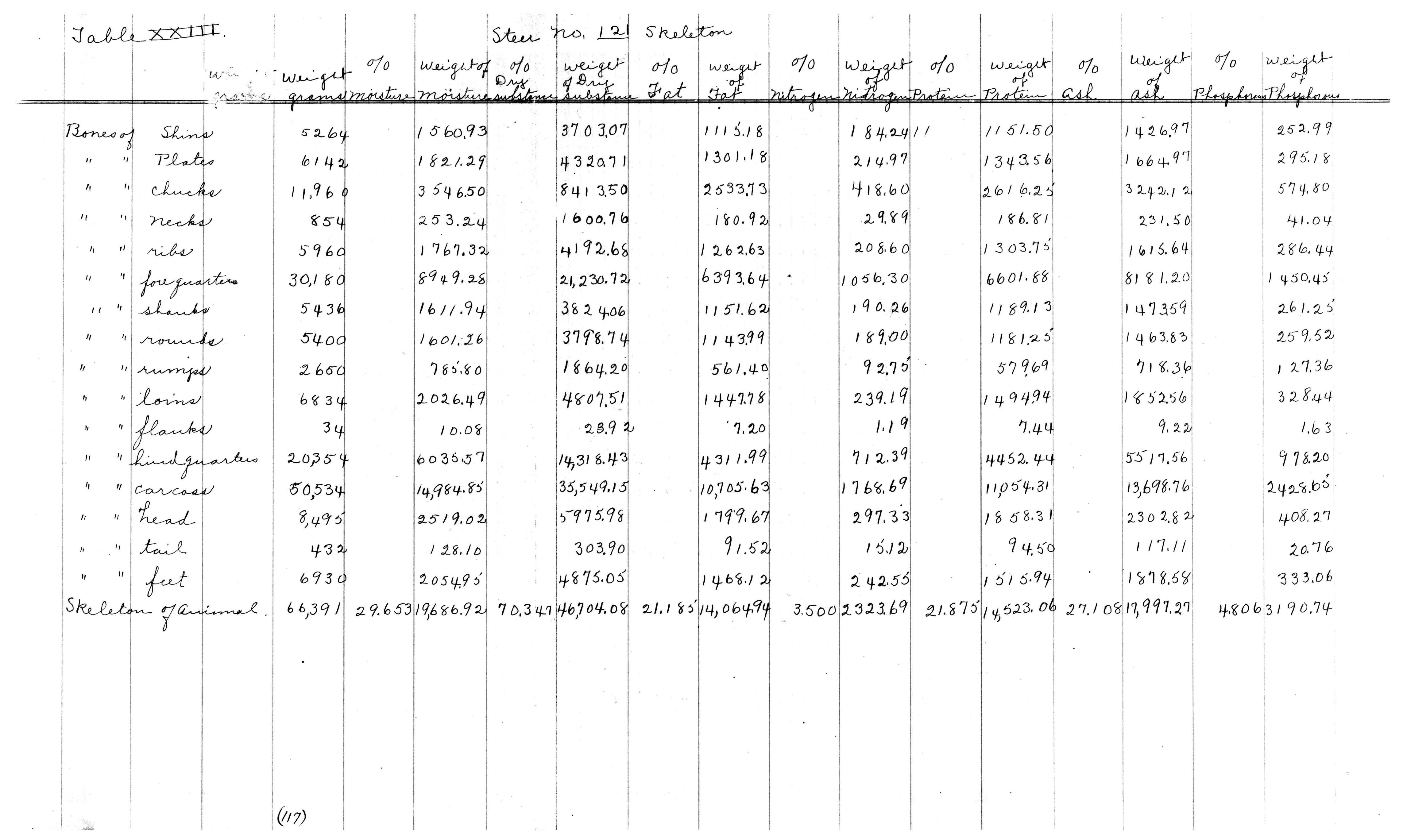


Lean of shims

" "chucks

" "neck.

" " ribs

"forequartes 132,330

"shauks

$"$ roucuda

"rumps

"loins

"flanks

"hiedquarters

"carcass

head

tail

arimal
57.844614 .48

$27,690 \quad 30.158348 .54$

$69,912 \quad 49.6734,725.29$

$2,500 \quad 49.671241 .75^{\circ}$

$24,250 \quad 56.8613,788.55$

$47,39662,7 / 8.61$

57.842064 .89

$50,284 \quad 64.4332,397.98$

$7088 \quad 36.912616 .18$

$43154 \quad 61.7826,660,54$

$6748 \quad 30.152034 .52$

$59.34065,774.11$

$52.840128,492.72$

$57.84 / 734.04$

$57.84 / 09.90$

190

246,362
42.163363 .52 $69.8519,341.46$

$50.3335,186.71$

$50.33 / 258.25$

$43.1410,461.45$

$52.60469,611.39$

$42.16 \mid 1505.11$

$35.57 / 7,886.02$

63.094471 .82

$38.2216,493.46$

69.854713 .48

$40.660445,069.89$

$47.160114,681.28$

$42 / 61263.96$

$42.16 \quad 80.10$

$47.095116,025.34$
23.471872 .44

$6 / .11 / 6,921.36$

34.9524434 .24

$34.95873 .75^{\circ}$

24.796011 .58

$37.87050,113.37$

$23.47 \quad 837.88$

| 3.426748 .1 |

$3-2.673733 .25$

18.267879 .92

$61.1 ! 4123.70$

$21.04123,322.86$

$30.19973,436.23$

23.47703 .63

$23,47 \quad 44.59$

$30.11374,184.40^{\circ}$
$2.863227 .6 / 17.831 / 422.56$

$1.308 \quad 362.19 \quad 8.1752263 .69$

$2.2671584 .91 \quad 14.1699905 .69$

$\begin{array}{lllll}2.267 & 56.68 & 14.169 & 354.25\end{array}$

$2.679649 .66 / 6.7444070 .38$

2.1772881 .05 13.606/8,006.56

$2.853 \quad 101.85 / 7.831 \quad 636.56$

$3.2781648 .31 \quad 20.48810,301.94$

$1.587 \quad 12.49 \quad 9.919703 .06$

$2.981 / 286.42 \quad 18.6318040 .02$

$\begin{array}{llll}1.308 & 88.26 & 8.175 & 551.63\end{array}$

$2.9263237 .33 \quad 18.28820,233.31$

$2,5+661+8.38 / 5.72538,239.88$

\begin{tabular}{ll|l|l}
2.853 & 85.53 & 17.831 & 534.58
\end{tabular}

$2.853 \quad 5.4217 .831 \quad 33.88$

$2.5206209 .33 \quad 15.75038,808.31$
$0.829 \quad 66.14$

0.421116 .57

$0.693 \quad 484.49$

$0.693 \quad 173.25$

0.827200 .55

$0.787 / 041.00$

$0.829 \cdot 29.59$

$1.015 \quad 510.38$

0.50936 .08

0.956412 .55

$0.421 \quad 28.41$

0.9181017 .01

0.84620 .5801

0.8292485

$0.829 \quad 1.58$

0.8462084 .44
$0.142 \quad 11.33$

$0.064,7.72$

$0.123 \quad 85.99$

$0.123 \quad 3.08$

$0.150 \quad 36.38$

$0.117 \quad 1.54 .50$

$0.142 \quad 5.07$

$0.192 \quad 96.55^{3}$ $.0 .093 \quad 6.59$

$0.174 \quad 75.09$

$0.064 \quad 4.32$ $0,169,87.62$ $0.141 \cdot 342.12$

$0.14^{2} \quad 4.26$

$0.14^{2} \quad .27$

0.141134663 
Steer no. 48. Inat.

weight

010

weight

of o weiget ofo we

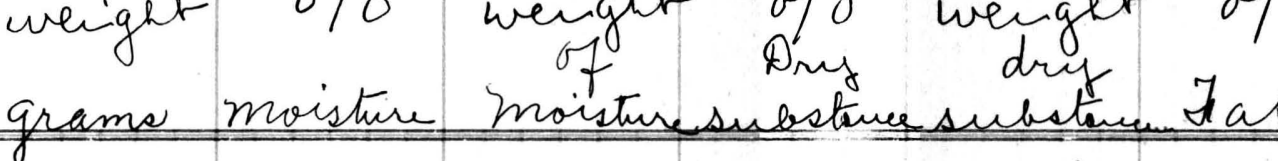

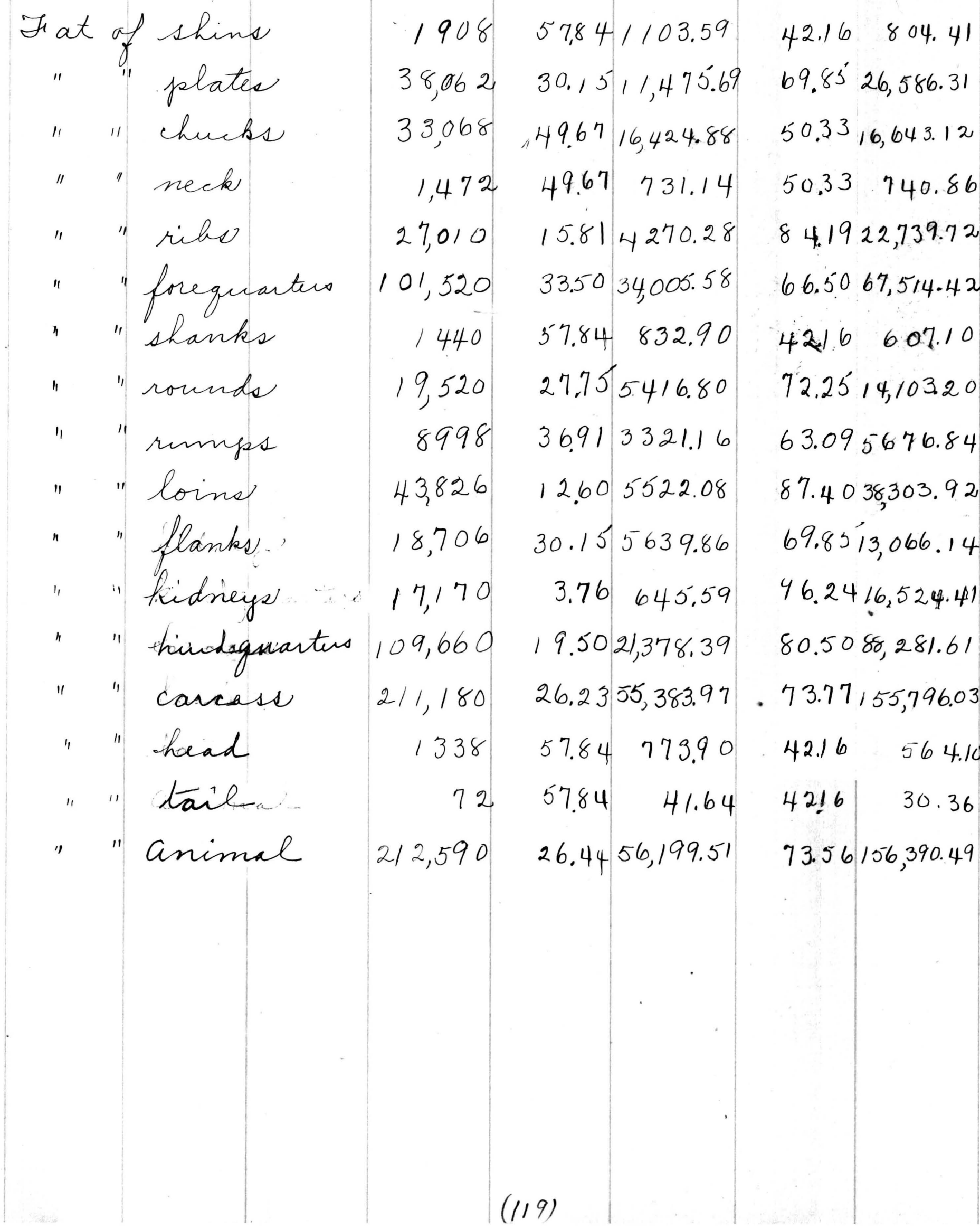

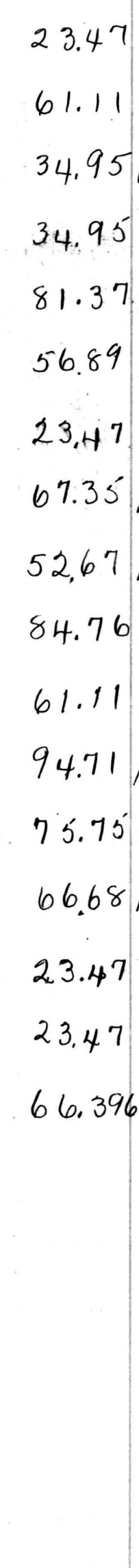

$23.47 \quad 447.81$

$61.1123,259.69$

2.853

97.85

$7.831 \quad 340.25$

$8.175 \cdot 3111.56$

$2.267 \quad 749.65 \cdot 14.169 .4685 .31$

2.26733 .37

14.169208 .56

$\begin{array}{lllll}0.431 & 116.41 & 2.694 & 727.56\end{array}$

$1.4301451 .72 \quad 8.9389073 .25$

$7.831 \quad 256.75$

$67.3513,146.72$

4.7

81933.31

4739.23

$1.587,42.80$

$9.919 \quad 892.50$

2.6631166 .88

$$
8.1 \%
$$

8.1751529 .19

$1.494 \quad 256.50$

4.5945035 .13

$1.0692257 .34 \quad 6.68114,108.36$

7.831228 .56

17.831

12.81

$6.75614 .359 .75^{\prime}$

\begin{tabular}{r|r|r|r}
0.829 & 15.82 & 0.142 & 2.71 \\
0.421 & 160.24 & 0.064 & 24.36 \\
\hline 0.693 & 229.16 & 0.123 & 40.67 \\
0.693 & 10.20 & 0.123 & 1.81 \\
0.156 & 41.87 & 0.021 & 5.67 \\
0.450 & 457.29 & 0.074 & 75.22 \\
0.829 & 11.94 & 0.142 & 2.04 \\
0.251 & 49.00 & 0.027 & 5.27 \\
0.509 & 45.80 & 0.093 & 8.37 \\
\hline 0.146 & 63.99 & 0.023 & 10.08 \\
0.421 & 78.75 & 0.064 & 11.97 \\
0.126 & 21.63 & 0.016 & 2.75 \\
\hline 0.247 & 271.11 & 0.037 & 40.48 \\
0.345 & 728.40 & 0.055 & 115.70 \\
0.829 & 11.09 & 0.142 & 1.90 \\
0.829 & 0.60 & 0.142 & .10 \\
0.348 & 740.09 & 0.055 & 117.70
\end{tabular}




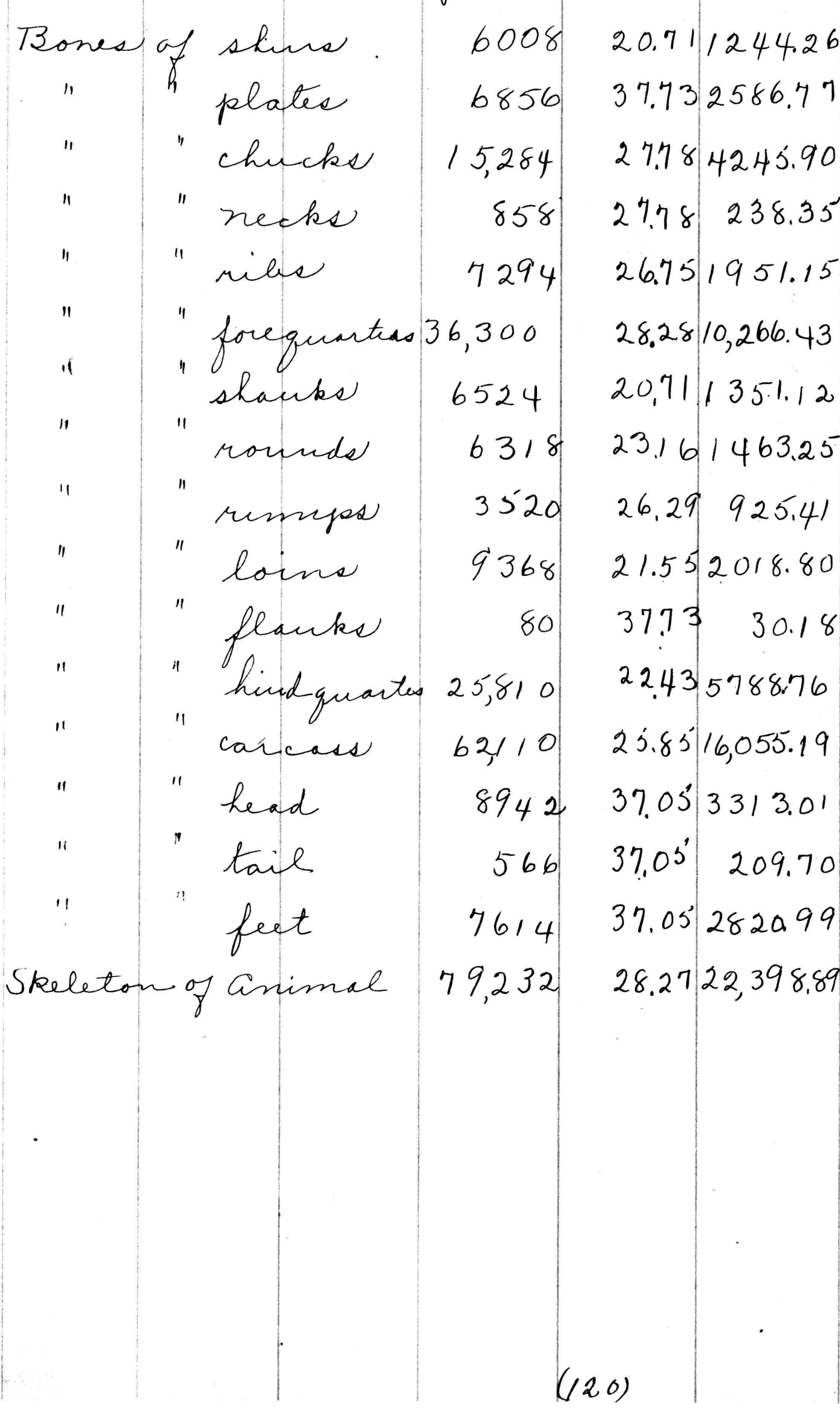

$79.294763 .7424 .344 / 462.59$ $62.274269 .23 \quad 19.5671341 .51$

$72.2211,038.10 \quad 18.655 \quad 2851.23$ $\begin{array}{lllll}72.22 & 619.65 & 18.655 & 150.06\end{array}$

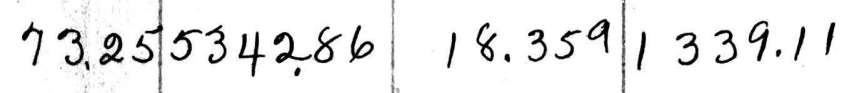
$71.7226,033.57 \quad 19.680 .7144 .50$ $79.295172 .88 \cdot 24.3441588 .20$ $76.844854 .73^{\prime 2} 32.4792052 .02$ $73.71 .2594 .59 \quad 35.688 / 256.22$ $78.457349 .20 \quad 29.6032773 .21$ $62.27 \quad 49.82 \quad 19.567 \quad 15.65$ $77.5720,021.2429 .7767685 .30$ $74.1546,054.8123 .86114,829.80$ $62.955628 .99 \quad 11.519,1030.0 .3$ $62.93 \quad 356.3011 .519 \quad 65.20$ $62.954793 .01 \quad 11.519877 .06$ $71.7356,833.1121 .20616,802.09$
$3.202192 .38 \quad 20.0131202 .38$ $2.999205 .61 \quad 18.74412845 .06$ $3527 \quad 539.07 \quad 22.0443369 .19$ $\begin{array}{llll}3527 & 30.26 \quad 22.044 & 189.13\end{array}$ $3303240.92 \quad 20.6 .441505 .75$ $3.3281208 .24 \quad 20.8007551 .50$ 3.2020208 .9020 .0131305 .63 $2.124 \quad 134.19 \quad 13.275 \quad 838.69$ $\begin{array}{llll}2.294 \quad 80.75 \quad 14.338 & 504.69\end{array}$ $2.820264 .18 \quad 17.6251651 .13$ $2.999 \quad 2.40 \quad 18.744 \quad 15.00$ $2.695 \quad 690.42 \quad 16.719 \$ 315.13$ $3.0571898 .66 \quad 19.10610,866.63$ 3.429306 .6221 .4311 .916 .38 $\begin{array}{lllll}3.429 & 19.41 \quad 21.431 \quad 121.31\end{array}$ $3.429 \quad 261.08 \quad 21.431 \quad 1631.75$ $3.1372485 .77 \quad 19.606 \quad 15,536.06$
33.041985 .04 20.221386 .28 27.534207 .69 $27,53 \quad 236.21$ 29.412145 .17 27.4399960 .39 33.04215543 27.071710 .28 $20,65 \quad 726.88$ 26.092444 .11 $20.22 \quad 16.18$ 27.3267052 .88 $27.39217,013.27$ 24.51219 24.51138 .73 24.511866 .19 26.76921209 .87
6.17337087 $3.772 \quad 258.61$ $5073 \quad 775.36$ $5.073-43.5^{3}$ 5.416395 .04 5.0781843 .41 $6.173 \quad 402.73$ 5.020317 .16 $3.891 \quad 36.96$ $4.805^{\prime} \quad 450.13$ $3.772 \quad 3.02$ $5.076 / 310.00$ 5.0773153 .41 4.635414 .46 $4635 \quad 26.23$ $4.633^{\prime} 352.91$ 4.9823947 .01 
Forequarters

Shins Lean

shins Fat
shins Bone

rotal cut of Shins

Plates Lean

P1ates Fat

Plates Bono

lotal cut of Plates

Shuoks Lean

Chucks inat

Shucks Bons

Iotal cut of chuoks

Irecks Lean

locks Fat

Total cut or nook

Ribs Lean

ritbs Fat

kibs Bone

lotal cut of Ribs

Porsquart or:s Loan

orequarters Fat

'orequart ters Bone

iota1 Forequarters

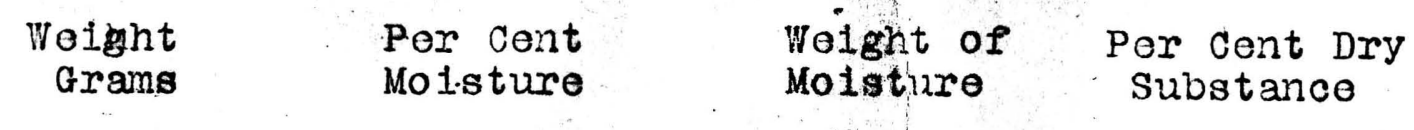

$4680 \quad 67.433$

$870 \quad 67.433$

$10314 . \quad 49.354$.

$11768 . \quad 52.512$

$5242 . \quad 52.512$

$4980 \quad 28.292$

$21990 \quad 47.027$

$38058 . \quad 66.48$ ?

$3664 . \quad 66.480$

$11222 . \quad 28.292$

52.944, 58.386 .

$780 \quad 28.292$

$3066 . \quad 56.765$

$\begin{array}{cc}3066 . & 56.765 \\ 12338 . & 62.79\end{array}$

$1422 . \quad 62.79$

$4712 . \quad 28.292$

$18472 . \quad 53.990$

$69130 \div \quad 63.508$.

$26458 . \quad 28.292$

$106786 . \quad 54.363$.

$3155.86 \quad 32.56 \%$

$586.67 \quad 32.567$.

$\begin{array}{ll}1347.83 & 71.708 . \\ 500.36 & 50.646\end{array}$

$61 \% 9.61 \quad 47.488$

$27.52 .68 \quad 47.488$

$1408.94 \quad 71.708$

$10341.23 \quad 52.973$

$2530096 \quad 33.52$

$243583=33.52$

$3174.93 \quad 71.708$

$309.1 .72 \quad 41.614$

$1519.73 \quad 33.52$

2.10.68 71.708

$\begin{array}{rr}2 p 0.68 & 71.708 \\ 174.41 & 43.235\end{array}$

$77+7.03 \quad 37.210$

$8.2 .87 \quad 37.210$

$133.12 \quad 71.708$

$9.9^{\prime \prime} 3.02 \quad 46.010$

$439 \cdot 3.19 \quad 36.492$

$6613.05 \quad 40.45$

$74 \div .50 \quad 71.708$

58 0! $6.74,45.632$
$4764 . \quad 28.292$

$2286 . \quad 66.48$

$11198 . \quad 59.547$
Iable XXVII steur ho. 18.

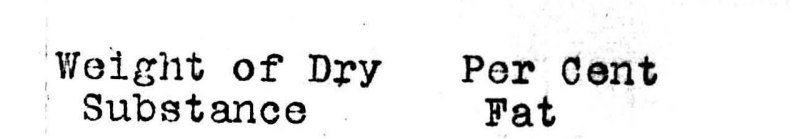

$283.33 \quad 11.990$.

$\begin{array}{ll}3416.17 & 25: 272 . \\ 5223.64 & 18.125\end{array}$

$5588.39 \quad 30.103$.

$2489.32 \quad 30.103$.

$3571.06 \quad 25.272$.

$\begin{array}{ll}11648.77 & 29.009 . \\ 12757.04 & 14.068\end{array}$

$1228.17 \quad 14.068$.

$8047.07 \quad 25,272$.

22032.28 16.443.

766. $27 \quad 14.068$.

$559.32 \quad 25.272$.

$1325.59 \quad 16.918$.

$4590.97 \quad 18.037$.

$529.13 \quad 18.037$.

$3378.88 \quad 25.272$

$8498.98 \quad 19.883$.

$25226.81 \quad 17.367$.

$\begin{array}{rr}4529.95 & 21.917 . \\ 18972.50 & 25.272 .\end{array}$

$48729.26 \quad 19.802$.
$1258.55 \quad 3.022$.

$\begin{array}{ccrc}\begin{array}{c}\text { We1ght of } \\ \text { Fat }\end{array} & \begin{array}{c}\text { Por dont } \\ \text { N1trogon }\end{array} & \begin{array}{c}\text { We1ght of } \\ \text { N1trogen }\end{array} & \begin{array}{l}\text { Per cont } \\ \text { Protein }\end{array} \\ 561.13 & 3.219 . & 150.65 & 20.119 . \\ 104.31 & 3.219 . & 28.01 & 20.119 . \\ 1203.96 & 3.022 . & 143.97 & 18.888 . \\ 1869.40 & 3.128 . & 322.63 & 19.550\end{array}$

$\begin{array}{llll}1869.40 & 3.128 & 322.63 & 19.550\end{array}$

$\begin{array}{llll}3542.52 & 2.440 & 287.14 & 15.250\end{array}$

$\begin{array}{llll}1578.00 & 2.440 & 127.90 & 15.250\end{array}$

$6379.07 \quad 2.572$.

$5354.00 \quad 3.019$.

$515.45 \quad 3.019$.

$2836.02 \quad 3.022$

$8705.47^{\circ} \quad 3.020$

$321.59 \quad 3.019$.

$197.12 \quad 3.022$

$518.71 \quad 3.020$

$2225.41 \quad 3.076$.

256. $49 \quad 3.076$.

$1190.82 \quad 3.022$.

$3672.72 \quad 3.062$.

$12004.65 \quad 2.944$.

$\begin{array}{ll}2454.25 & 2.771 . \\ 6686.47 & 3.022\end{array}$

$21145.37 \quad 2.945$.

$150.50 \quad 18.888$.

$565.54 \quad 16.075$.

$1148.97 \quad 18.869$.

$110.62 \quad 18.869$.

339. $13 \quad 18.888$.

$1598.72 \quad 18.875$.

69. $01 \quad 18.869$.

23.5718 .888$.

92. $58 \quad 18.875$.

379. $52 \quad 19.225$.

43. $74 \quad 19.225$.

$142.40 \quad 18.888$.

$565.66 \quad 19.138$.

$2035.29 \quad 18.400$

$310.27 \quad 17.319$.

799. $57 \quad 18.888$.

$3145.13 \quad 18.406$.
Weight of
Protoln

$941.66 \quad .771$.

175. 16

899. $\$ 1125.326$.

2016.43

1794.63
799.38

147. $31 \quad 25.326$

$\begin{array}{rr}578.62 & 7.053 . \\ 2372.00 & .821 .\end{array}$

890.00

$\begin{array}{rr}890.00 & 25.326 \\ 3535.38 & 7.072 .\end{array}$

3535. $38 \quad 7.072$

12720.56

.787.
.735.

$4997.31 \quad 25.326$

$19656 \% 9 . \quad 6.861$.

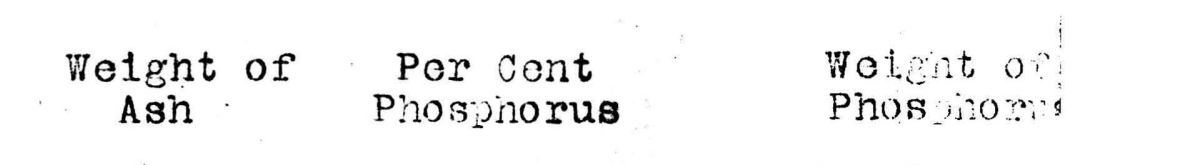

$\begin{array}{lll}36.08 & .145 . & 6.79\end{array}$

1206.530 .145$.

$\begin{array}{rr}1206.53 & 2.879 . \\ 1249.32 & 1.408 .\end{array}$

$34.02 \quad .124$.

1261.23

1371.62

311.31
29.97

2842.08
3183.36

18.70

$197.54 \quad 2.879$.

216. 24

101. 29

1167
1306.32

543.75

82. 37

6700.74

7326.86
$13 \% .16$

145. 21

14. 59

6. 50

143. 37

164.46

5.64
323.08

323.08

3.52

2.2. 46

25. 98

19. 86

2. 29

135.66

157. 81

103. 37

15.69

761.73

880.79 
Shanks Lean

Shanks pat

rotal cut of shanks

Rounds Lean

Rounds pat

Tot:il cut of Round

Rumps Liean

Rumps Fat

Rumps Bone
Total cut of

Lo1n Lean

Lo1n Fat

Loọn Bone

rotal cut of Loin

Franks Lean

Flanks Fat

PI lanks Bone

Total cut of Flanks

7.at of K1dnoys

Hindquarters Fat

Itindquarters Bone

rotal Hindquarters

Hindyearters.

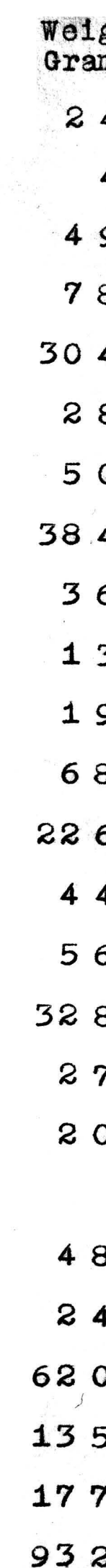

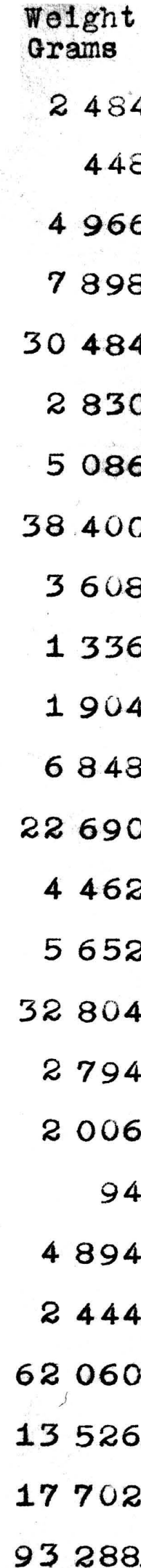

I able XXVII, contd. Ster no, 18

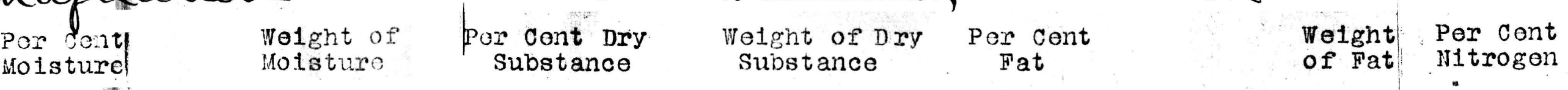

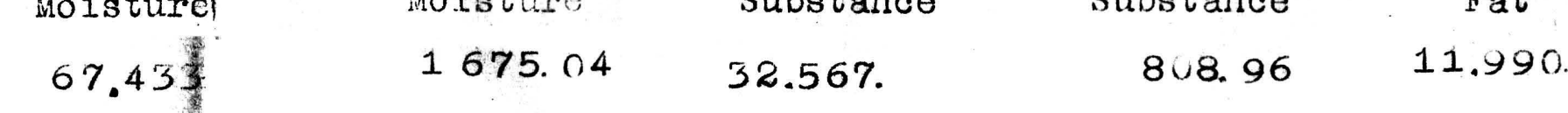

$\begin{array}{lll}67.433 & 302.10 \quad 32.567\end{array}$

$145.90 \quad 11.990$

$28.298 \quad 1404.98 \quad 71.708$

$42.822 \quad 3382.12 \quad 57.178$

$\begin{array}{rrr}66.503 & 1882.03 & 33.497\end{array}$

$3561.02 \quad 25.272$

$4515.88 \quad 20.341$.

$10211.23 \quad 13.258$

$\begin{array}{ll}947.97 & 13.258 . \\ 3647.07 & 25.272\end{array}$

$1438.93 \quad 71.708$

$23593.73 \quad 38.558$

$66.503 \quad 2399.43 \quad 33.497$.

$\begin{array}{lll}66.509 & 888.48 & 33.497\end{array}$

$\begin{array}{lll}28.293 & 538.68 & 71.708\end{array}$

$55.87 \%$

59.900

$\begin{array}{rr}538.68 & 71.708 \\ 3826.59 & 44.121\end{array}$

$\begin{array}{rr}13591.31 & 40.100\end{array}$

$2672.74 \quad 40.100$

$1599.06 \quad 71.708$

$17863.11 \quad 45.546$

$1467.19 \quad 47.488$

$1053.39 \quad 47.488$

26. $59 \quad 71.708$

$2547.17 \quad 47.953$

$245.48 \quad 89.956$

$39405.74 \quad 36.504$

$\begin{array}{ll}7044.22 & 47.921\end{array}$

$5008.24 \quad 71.708$

$\begin{array}{rr}14806.27 & 14.849\end{array}$

$1208.57 \quad 13.258$

$447.52 \quad 13.258$

$1365.32 \quad 25.272$

$3021.41 \quad 16.598$

$9098.69 \quad 21.719$

$1789.26 \quad 21.719$.

\begin{tabular}{l}
$4052.94 \quad 25.272$ \\
\hline 494089
\end{tabular}

$1326.81 \quad 30.103$

$952.61 \quad 30.103$.

$\begin{array}{ll}67.41 & 25.272\end{array}$

$2346.83 \quad 30.010$

$2198.52 \quad 86.962$

$22654.26 \quad 17.059$

$6481.78 \quad 38.528$.

$\begin{array}{ll}62693.76 & 25.272 \\ 41829.80 & 20.758\end{array}$

\begin{tabular}{r|r}
297.83 & 3.219. \\
53.72 & 3.219. \\
1255.01 & 3.022. \\
1606.56 & 3.095. \\
4041.57 & 3.110 \\
375.20 & 3.110 \\
1285.33 & 3.022. \\
5702.10 & 3.098. \\
478.35 & 3.110. \\
177.13 & 3.110 \\
481.18 & 3.022. \\
1136.66 & 3.086. \\
4928.04 & 2.866. \\
969.10 & 2.866. \\
1428.37 & 3.022. \\
7325.51 & 2.893. \\
841.08 & 2.440. \\
603.87 & 2.440. \\
23.76 & 3.022. \\
1468.71 & 2.451. \\
2125.35 & .421. \\
10586.87 & 2.995. \\
4304.37 & 2.448. \\
4473.65 & 3.022. \\
19364.89 & 2.921.
\end{tabular}

\begin{tabular}{c|c} 
Wetght of \\
Nittrogon
\end{tabular}

79.9620 .119$.

$150.07 \quad 18.888$

$244.45 \quad 19.344$.

$948.05 \quad 19.438$.

$88.01 \quad 19.438$.

$153.70 \quad 18.888$.

$189.76 \quad 19.363$

$112.21 \quad 19.438$

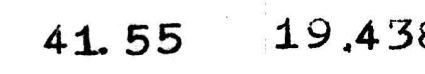

$57.54 \quad 18.888$.

$211.30 \quad 19.283$.

$650.30 \quad 17.913$.

$127.88 \quad 17.913$.

$170.80 \quad 18.888$.

$948.98 \quad 18.081$

$68.17 \quad 15.25$

48. $95 \quad 15.25$

2. $84 \quad 18.888$.

$119.96 \quad 15.319$

10. $29 \quad 2.631$

$858.69 \quad 18.719$

$331.10 \quad 15,300$

$534.95 \quad 18.880$

$2724.74 \quad 18.256$

\begin{tabular}{|c|c|}
\hline $\begin{array}{l}\text { Wretght of } \\
\text { Protgin in }\end{array}$ & 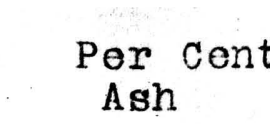 \\
\hline 499,75 & .771 \\
\hline 9013 & .771. \\
\hline 93794 & 25.326. \\
\hline 152782 & 16.210 \\
\hline \begin{tabular}{ll|l}
59251 & 31
\end{tabular} & .883 \\
\hline 5506 & .883. \\
\hline 96063 & 25.326. \\
\hline $7436 \mid 00$ & 4.120 \\
\hline 70131 & .883 \\
\hline $25 y \mid 69$ & .883. \\
\hline $359 \mid 63$ & 25.326. \\
\hline 13: 63 & 7.679. \\
\hline 406438 & .788. \\
\hline 79925 & .788. \\
\hline 106750 & 25.326. \\
\hline $5931: 13$ & 5.016. \\
\hline 42606 & .649. \\
\hline 30594 & .649 \\
\hline 1775 & 25.326. \\
\hline 74975 & 1.123. \\
\hline $64 / 31$ & .120 \\
\hline 1161 | 81 & .833. \\
\hline $206: 38$ & .675 \\
\hline 334345 & $25,326$. \\
\hline 170284 & 5.458. \\
\hline
\end{tabular}

$\begin{array}{ll}\text { Weight of } & \begin{array}{l}\text { Per cent } \\ \text { phh }\end{array} \\ \text { phosonorus }\end{array}$

Welght of
Phosphorus
3.60

$55.161 \quad 51458.20 \quad 44.839$

19364.89

$\begin{array}{rr}19.15 & .145 \\ 3.45 & .145 . \\ 1257.69 & 2.879 \\ 1280.29 & 1.864 \\ 269.17 & .172 . \\ 24.99 & .172 . \\ 1288.08 & 2.879 \\ 1582.24 & .531 \\ 31.86 & .172 . \\ 11.80 & .172 . \\ 482.21 & 2.879 \\ 525.87 & .925 . \\ 178.80 & .157 \\ 35.16 & .157 \\ 1431.43 & 2.879 \\ 1645.39 & .626 . \\ 18.13 & .124 . \\ 13.02 & .124 \\ 23.81 & 2.879 \\ 54.96 & .177 . \\ 2.93 & .021 . \\ 517.11 & .163 . \\ 91.35 & .132 . \\ 4483.22 & 2.879 . \\ 5091.68 & .674 .\end{array}$


Careass.

Porequarters Lean

liindquarters Lean

carcass Lean

Poreguarters Fat

Hindquarters $\mathrm{Fa}$
CRrcass Fat

Porequarters Bone

Hindquart ors Bono

Carcass Bone.

rotal Carcass

Hoad Lean

inead Fat

Fot al Headi (excl. Teeth and Horn)

Tai.1 Lean

Tail Bone

Total Tas1

Peat Less Hoofs

Iable XXVIII. Steer ho.18.

\begin{tabular}{|c|c|c|c|c|c|c|c|c|c|c|c|c|c|c|}
\hline $\begin{array}{l}\text { Weight } \\
\text { Gramis }\end{array}$ & $\begin{array}{l}\text { Per Cerit } \\
\text { Moisturo }\end{array}$ & $\begin{array}{l}\text { Weight of } \\
\text { Moisturese }\end{array}$ & $\begin{array}{l}\text { Percent Dry } \\
\text { Substanco }\end{array}$ & $\begin{array}{l}\text { Woight of Dry } \\
\text { Surstance }\end{array}$ & 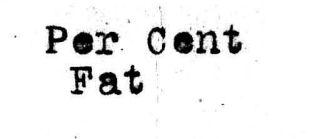 & Wolght of & $\begin{array}{l}\text { Por cont } \\
\text { Nitrogon }\end{array}$ & $\begin{array}{l}\text { Woight of } \\
\text { Nitrogen }\end{array}$ & $\begin{array}{l}\text { Por cont } \\
\text { Protoin }\end{array}$ & $\begin{array}{l}\text { votght of } \\
\text { Prot on }\end{array}$ & $\begin{array}{l}\text { Porr Cont } \\
\text { Ash }\end{array}$ & $\begin{array}{l}\text { Troight of } \\
\text { Ash }\end{array}$ & $\begin{array}{l}\text { Pere cont } \\
\text { Phospinorus }\end{array}$ & $\begin{array}{l}\text { Walght of } \\
\text { Phosphorus } \\
10 \%\end{array}$ \\
\hline 69130. & 6350 & 43903.19 & 36492 & 25226.81 & 17367.00 & 12004.65 & 2.944 & & & & & & & \\
\hline 62060 & 6349. & 39405.74 & 36504. & 22654.26 & 17059.00 & 1586.87 & 2,995 & 1858.69 & 18,719 & 11615.81 & 833. & 517.11 & .163. & 101.32 \\
\hline 131190 & 6350 & 83308.93 & 36497. & 47881.07 & 17220 & 22591.52 & 2.968 & 3893.98 & 18.550 & 24331.37 & 809 & 1060.86 & .156. & 204.69 \\
\hline 11198. & 5954 & 6668.05 & 40453 & 4529.95 & 21917. & 2454.25 & 2.771 & 310.27 & 17.319 & 193.12 & 735. & 82.37 & .140. & 15.69 \\
\hline 13526. & $520 \%$ & 7044.22 & 47921. & 6481.78 & 38528. & 4304.37 & 2.448 & 331.10 & $15.30 \%$ & 206938 & 675. & 91.35 & .132. & 17.83 \\
\hline 24724. & 5546 & 13712.27 & 44539 & 11011.73 & 27337. & 6758.62 & 2,594 & 641.37 & 16.213 & 4003.57 & 703. & 173.72 & 136. & 33.52 \\
\hline 26458. & 2829 & 7485.50 & 71708. & 18972.50 & 25272. & 6686.46 & 3.022. & 799.57 & 18.888 & 4999.31 & 25326. & 6700.74 & 2,879 & 761.73 \\
\hline 17702. & 2829 & 5008.24. & 71708 & 12693.76 & 25272. & 4473.65 & 3.022. & 534.95 & 18.888. & 3343.45 & 25326. & 4483.22 & 2,879 & 509.65 \\
\hline 44160 & 2829 & 12493.74 & 71708 & 31666.26 & 25272. & 11160.12 & 3.022. & 1334.52 & $18,888$. & 834,75 & 25326. & 11183.96 & 2.879 & 1271.38 \\
\hline 200074 & $5473 \%$ & 109514.94 & 45.263. & 90559.06 & 20248. & 40510.26 & 2.934 & 5869.87 & $18,333$. & 36685.69 & 6207 & 12418.54 & .755 & 1509.59 \\
\hline 2968. & 6743 & 2001.41 & 32567. & 966.59 & 11990. & 355.86 & 3.219. & 95.54 & 20,119 & 597.13 & 771 & 22. 88 & .145 & 4. 30 \\
\hline 436. & 6743 & 294.01 & 32567 & 141.99 & 11990. & 52.28 & 3.219 & 14.03 & 20.119 & $8 p .69$ & 771. & 3. 36 & .145 & 63 \\
\hline 7311. & $2829:$ & 2068.43 & 71708 & 5242.57 & 25272 & 1847.64 & 3.022. & 220.94 & $18.88,8$. & \begin{tabular}{l|l}
138 & 88
\end{tabular} & 25326. & 1851.58 & 2,879 & 210.48 \\
\hline 10715. & 4072 & 4363.85 & 59273. & 6351.15 & 21053 & 2255.78 & 3.085 & 330.51 & 19.281 & $206 \$ 5.69$ & 17524. & 1877.82 & $2 \cdot 010$ & 215. 41 \\
\hline 220 & 6743 & 148.35 & 32567 & 71.65 & 11990 & 26.38 & 3.219. & 7.08 & 20.119 & 44.25 & 771. & 1. 70 & .145 & 32 \\
\hline 464. & 2829 & 131.27 & 71708 & 33273 & 25272 & 117.26 & $3,022$. & 14. 02 & 18.888 & 87.63 & 25326. & 117.51 & 2.879 & 13.36 \\
\hline 684. & 4088 & 279.62 & 59120 & 40438 & 21000. & 143.64 & 3.085 & 21.10 & 19.281 & 131.88 & 17428 & 119.21 & 2,000 & 13.68 \\
\hline & 2829 & 1789.75 & 71708. & 4536.25 & 25272 & 1598.71 & 3.022. & 191.17 & 18.883. & 1 19f. 81 & 25326. & 1602.12 & $2,879$. & 182.13 \\
\hline
\end{tabular}


Total Antral Loan

Total A:ilmal pat (insss offal pat)

Potal Animal Bone

Hatre and Hide

1002

Circulatory System

Resplratory syst om

vorvous system

festive and Excrotory Syst

rotal nintmal

15599.

2594.

3079.

725.

21823.

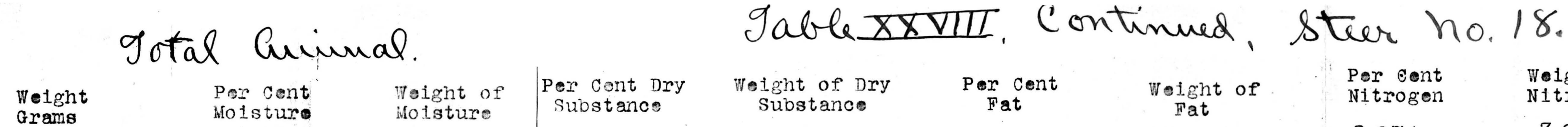

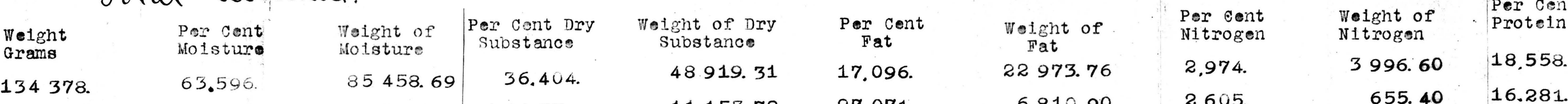

\begin{tabular}{llll|l}
58261 & 29298 & 16483.19 & 71.708
\end{tabular}

\begin{tabular}{llll|l}
25674. & 65.365 & .16781 .81 & 34.635.
\end{tabular}

\begin{tabular}{llll|l}
5700 & 16.62 & 947.30 & 83.380
\end{tabular}

$81,296 \quad 1268040 \quad 18.71 \%$

$918.60 \quad .429$.

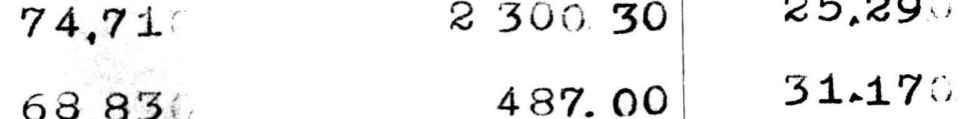

$\begin{array}{lll}67.106 & 14644.65 & 32,894 .\end{array}$

$12774078 \quad 18,589$. $\begin{array}{ll}48.919 .31 & 17.096 . \\ 11153.72 & 27.071 .\end{array}$

$41777.81 \quad 25.272$

\begin{tabular}{r|rrr|r}
22973.76 & 2.974. & 3996.60 & 18.558. \\
6810.90 & 2.605. & 655.40 & 16.281.
\end{tabular}

$14723.73 \quad 3.022$

$\begin{array}{ll}655.40 & 16.281 . \\ 760.65 & 18.888 .\end{array}$

$1308.30 \quad 31.85$

752. $70 \quad 79.718$.

$1128.40 \quad 30,068$

$66.92 \quad 2.909$.

779. $96 \quad 1.996$.

198. 90

127.30

2.756.
1.750

225. $00 \quad 17.625$.

$7178.35 \quad 16.037$

29. 47.18 .181$.

$51.78 \quad 12.475$.

84. $86 \quad 17,225$.

$12.64,10.938$.

$483.41 \quad 13.844$.

\begin{tabular}{|l|l|l}
14644.65 & 38.894 \\
\hline
\end{tabular}

$\begin{array}{llll}54465.261 & 3.016 . & 8836.88 \mathrm{a} & 18.85\end{array}$

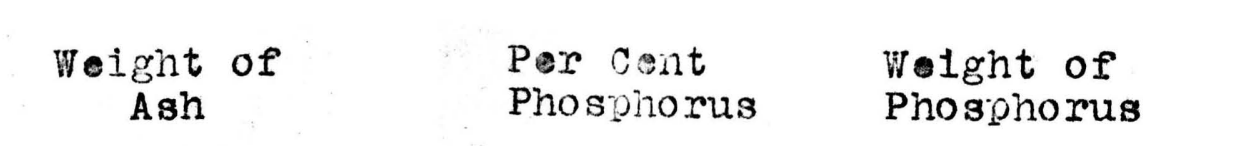

24978.75

409626

1100407

8177

283610
1085.44

177.08

4755.17

222.85
9.80

9.80
107.32

19.48

29.53

12.69

342.40

16781.76 $\begin{array}{ll}156 . & \text { Phosphorus } \\ 136.31\end{array}$

.136.

2.879.
.068.

1677.35

17. 46

$\begin{array}{lll}323 & 60 & .751 \\ 5.33 & 40 & .058\end{array}$

$\begin{array}{rr}78 & 97 \\ 0.757\end{array}$

$55230.50 \quad 5.721$. 


\begin{tabular}{|c|c|c|c|c|c|c|c|c|c|c|c|c|}
\hline 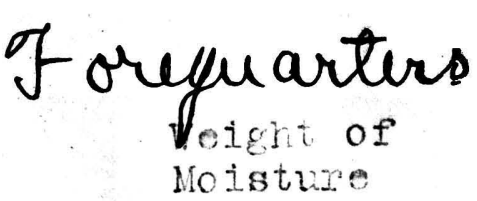 & $\begin{array}{l}\text { Perr ofnt Dry } \\
\text { subsent anceo }\end{array}$ & $\begin{array}{l}\text { Weight of of Dry } \\
\text { subst ance }\end{array}$ & 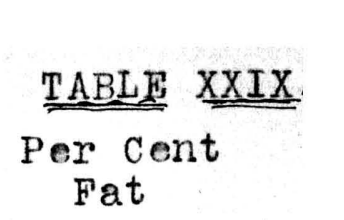 & $\begin{array}{l}\text { Steer } n \\
\text { vetight of } \\
\text { Fat }\end{array}$ & 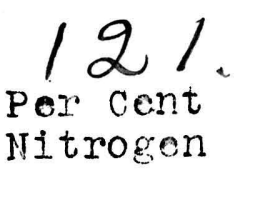 & $\begin{array}{c}\text { weidght of } \\
\text { witrogegen }\end{array}$ & $\begin{array}{l}\text { Per e ent } \\
\text { Protenn }\end{array}$ & $\begin{array}{l}\text { Wesigty of } \\
\text { Proto in }\end{array}$ & 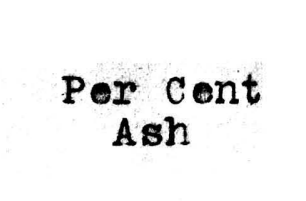 & 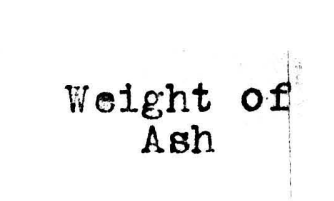 & $\begin{array}{l}\text { Proer Cent } \\
\text { Phosphorus }\end{array}$ & $\begin{array}{l}\text { Neight of } \\
\text { Phosphorns }\end{array}$ \\
\hline 5011.01 & 37.705. & 3032.99 & 18,183. & 1462.64 & 2,929 & $\begin{array}{r}235.61 \\
5.22\end{array}$ & $\begin{array}{l}18,310 \\
18,310\end{array}$ & 147956 & $\begin{array}{r}.733 . \\
733 .\end{array}$ & $\begin{array}{l}58.96 \\
14.82\end{array}$ & $\begin{array}{l}.148 \\
.142 .\end{array}$ & $\begin{array}{l}11.42 \\
2.87 \\
\text { a. }\end{array}$ \\
\hline 1259.60 & 37.705 & 762.40 & 18.183 & 367.66 & 8.929 & $\begin{array}{r}59.22 \\
184.24\end{array}$ & $\begin{array}{l}18,310 \\
21875\end{array}$ & $\begin{array}{r}374.13 \\
115.60\end{array}$ & $\begin{array}{r}.733 . \\
27.108 .\end{array}$ & $\begin{array}{l}1428.98 \\
1426.97\end{array}$ & $\begin{array}{r}142 . \\
4,806\end{array}$ & $\begin{array}{r}2.87 \\
252.99\end{array}$ \\
\hline 1560.93 & 70.347 & 3703.07 & 21,185. & 1115.18 & 3.500 & $\begin{array}{l}184.24 \\
479.07\end{array}$ & $\begin{array}{l}21875 . \\
19,531 .\end{array}$ & $\begin{array}{l}199.140 \\
2994.19\end{array}$ & 9.790 & 1500.75 & $1,744$. & $\begin{array}{l}267.28 \\
267.28\end{array}$ \\
\hline 7831.54 & 48.914 & $\begin{array}{r}7498.46 \\
\end{array}$ & $\begin{array}{l}19.214 . \\
47701\end{array}$ & $\begin{array}{r}2945.48 \\
13761.74\end{array}$ & $\begin{array}{l}3,125 . \\
1,924 .\end{array}$ & $\begin{array}{l}479.07 \\
555.07\end{array}$ & 12.030 & 3469.19 & .500 & 144.25 & 095 & 27.41 \\
\hline 11561.06 & 59.927. & 17288.94 & $\begin{array}{l}\begin{array}{l}47.701 \\
47.701 .\end{array} \\
\end{array}$ & 8752.18 & 1.924 & 353.02 & $12,030$. & 2 2up. 38 & .500 & 91.74 & .095 & 17.43 \\
\hline 7352.59 & $59.92 \%$ & 10995.41 & 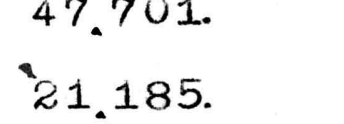 & 1301.18 & 3.500 & 214.97 & 21.875 & 1343.56 & 27,108 & 1664.97 & $4,806$. & 295.18 \\
\hline 1821.29 & 70.347 & 4320.71 & & 0 & 2105 & 1123.06 & 13,156 & $701 \phi 13$ & 3,564 & 1900.96 & 637. & $\begin{array}{l}340.18 \\
340.02\end{array}$ \\
\hline 20734.94 & 61.127. & 32605.06 & $\begin{array}{l}44.648 . \\
24.425 .\end{array}$ & $\begin{array}{l}\begin{array}{l}23815.10 \\
12155.83\end{array} \\
\end{array}$ & $\begin{array}{l}\begin{array}{l}2,105 \\
2,605\end{array} \\
2.0\end{array}$ & 129646 & 16.280 & 8,06 & 702 & 349.37 & 148. & $\begin{array}{r}\begin{array}{r}340.02 \\
70.67\end{array}\end{array}$ \\
\hline 29433.29 & 40.859 & 20334.71 & $\begin{array}{l}24.425 . \\
24.425 .\end{array}$ & $\begin{array}{r}12155.83 \\
4136.62\end{array}$ & $2,605$. & $\begin{array}{r}1296.46 \\
441.18\end{array}$ & $\begin{array}{l}16.280 \\
16\end{array}$ & 275.38 & .702 & 118.89 & 142 & $\begin{array}{r}70.67 \\
24.05\end{array}$ \\
\hline 10016.12 & 40.859 & 6919.88 & $\begin{array}{l}24.425 . \\
21.185\end{array}$ & $\begin{array}{l}4136.62 \\
2533.73\end{array}$ & $\begin{array}{l}2,605 \\
3,500\end{array}$ & 418.60 & 21.875 & 2615.25 & 27,148 & 3242.12 & 4.806. & 574.80 \\
\hline 3546.50 & 70.347. & 8413.50 & $\begin{array}{l}21.185 . \\
23938\end{array}$ & $\begin{array}{r}2533.73 \\
18826.18\end{array}$ & $\begin{array}{l}3,500 . \\
2,741\end{array}$ & 2156.24 & 17.131. & $134775: 50$ & 4.717 & 3710.38 & .851 & 669.52 \\
\hline 42995,91 & 45.342. & 35668.09 & 23.932. & 18 826. 18 & & 51.11 & 16,280 & $31 \% .44$ & 702 & 13.77 & .142. & \\
\hline 1160.35 & 40.859 & 801.65 & 24.425 & 479.22 & 2,605 & 20.58 & 16.280 & 123.63 & $70 z$ & 5.55 & .142. & $\begin{array}{l}2.79 \\
1.12\end{array}$ \\
\hline 467.21 & 40.859 & 322.79 & 24.425. & 192. 96 & 2.605 & $\begin{array}{l}20.58 \\
29.89\end{array}$ & $\begin{array}{l}81.875 \\
2.80\end{array}$ & $\begin{array}{l}186.81 \\
.181\end{array}$ & 27.108 & 231.50 & 4,806 & $\begin{array}{r}1.12 \\
41.04\end{array}$ \\
\hline 253.24 & 70.347 & 600.76 & 21.185 & 180.92 & 3.500 & 101.58 & 17.606. & 634.88 & 6.956. & 250.82 & 1,247 & 44. 95 \\
\hline 1880.80 & 47.848 & 1725.20 & 23.658. & 853.10 & 2.817 & 591.75 & 17.410. & 3695.44 & .777. & 165.03 & 1,153. & \\
\hline 12952.15 & 39.020 & 8287.85 & 20.874 & 4433.64 & 2.786 & 33.78 & 2.830 & 21.13 & 135. & 10.07 & $.02 \%$ & $\begin{array}{r}32.50 \\
2.01\end{array}$ \\
\hline 796.29 & 89.323. & 6661.71 & 86.035 & 6416.44 & .453. & & & & & 1615.64 & 4806 & $\begin{array}{r}2.01 \\
286.44\end{array}$ \\
\hline 1767.32 & 70.347 & 4192.68 & 21,185 & 1262.63 & 3.500 & 208.60 & 21.875. & 1300.75 & $87,108$. & 10150.04 & & $\begin{array}{l}286.44 \\
320.05\end{array}$ \\
\hline 15515.76 & 55.232. & 19142.24 & 34.941 & 12112.71 & 2.407 & 834.13 & 15.044. & $521 \mid 3.31$ & $5,167$. & 1790.74 & 926 & 320.95 \\
\hline 60117.86 & 45.280. & 49746.14 & 29.394. & 32293.07 & 2.485. & 2730.00 & 15.530. & $706 \mid 50$ & . & 731.38 & «3. & 144. 79 \\
\hline 19891.81 & 56.334. & 25662.19 & 43.610. & 19865.91 & $1,993$. & 907.78 & 12.456 & $56 \% \mid 3.65$ & .529 & 241.07 & 404. & 47.48 \\
\hline 8949.28 & 70.347. & 21230,72 & 21,185. & 6393.64 & 3.500 & 1056.30 & 21.875 & 6.691 .88 & 27,108 & 8181.20 & 48866 & 450.45 \\
\hline 8958.05 & $58,069$. & 96639.05 & 31.548. & 58552.62 & 2.529. & 4694.08 & 15.807 & $\begin{array}{lll}29 & 33\end{array}$ & 4932. & 9153.65 & 1885. & 1642.72 \\
\hline
\end{tabular}


F able XXIX continued, steir no. 121.

Shanks Lean

Shanks Fat

Shanks Bone

tal Cut of Shanks

Rounds Lean

ounds Fạt

tal cut of Round

Munps Lean

total cut of Rumpe

ton Lean

in

fotal cut of Loin

1.anks Lean

"lanks Bone

"otal Cut of Flanks

at of Kidneys

inciquarters Lean

Hndquarters Fat

Anindquarterss Bono

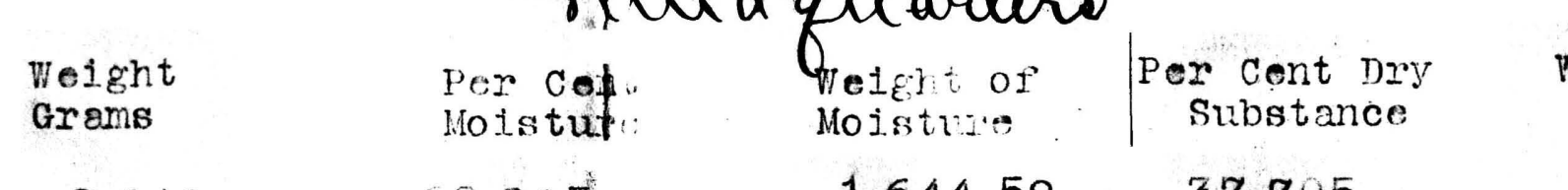

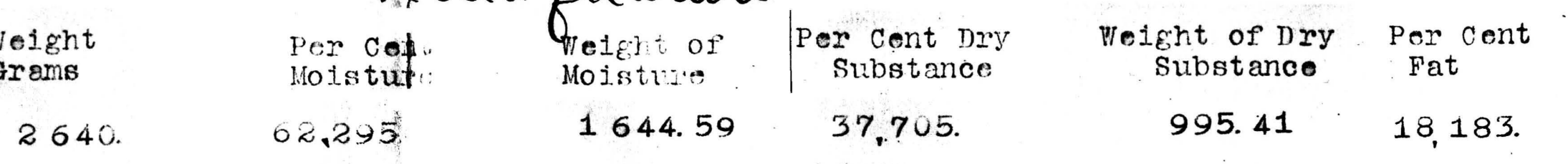

$\begin{array}{llll}1272: & 62,295 & 792.39 & 37,705 .\end{array}$

$\begin{array}{llll}5436 . & 29,653 & 1611.94 & 70,347 .\end{array}$

$\begin{array}{rrrr}9348 . & 43,313 & 4048.92 & 56,687 \\ 42448 . & 69,963 & 29697.89 & 30,037\end{array}$

$\begin{array}{llll}10.000 & 14.410 & 1441.00 & 85,590 .\end{array}$

$\begin{array}{llll}5.400 & 29.653 & 1601.26 & 70.347 .\end{array}$

$\begin{array}{llll}57848 . & 56.597 & 32740.15 & 43.403 .\end{array}$

$\begin{array}{llll}5334 . & 69,963 & 3731,83 & 30,037 .\end{array}$

$\begin{array}{llll}3924 . & 14.410 & 565.45 & 85,590 .\end{array}$

2650.

11908

33686.

20458.

42,686

67,228

9.075

9.075
29.653

43.508
40.073

40.073
40.073

40.073
29.653

$\begin{array}{rrr}29.65 \% & 10.08 & 70.347 \\ 40.03 \% & 3482.00 & 59.968 . \\ 4.484 & 326.08 & 95.516\end{array}$

$\begin{array}{rrr}4.484 & 326.08 & 95.516 .\end{array}$

$59332.98 \quad 32.682$.

$\begin{array}{lll}14.378 & 6838.46 & 85.622 . \\ 2 ., 653 & 6035.57 & 70.347\end{array}$

$46.271 \quad 72207.01 \quad 53.729$.

$\begin{array}{ll}995.41 & 18.183 \\ 479.61 & 18.183\end{array}$

$\begin{array}{rr}479.61 & 18,183 .\end{array}$

$\begin{array}{ll}3824.06 & 21,185 . \\ 5299.08 & 19,929 .\end{array}$

$12750.11 \quad 8,183$.

$8559.00 \quad 80,605$.

$3798.74 \quad 21,185$.

$25107.85 \quad 21,916$.

$1602.17 \quad 8,183$

$3358.55 \quad 80,605$.

$1864.20 \quad 21,185$

$\begin{array}{ll}6824.92 & 34,941 \\ 042.27 & 11.396\end{array}$

$18601.44 \quad 87.840$.

$4807.51 \quad 21,185$.

$34451.22 \quad 38.140$.

$2415.06 \quad 47,701$.

$2777.02 \quad 47,701$

23. $92 \quad 21,185$.

$6945.92 \quad 94.670$

$28805.82 \quad 11,517$.

$40721,54 \cdot 80,992$

$14318.43 \quad 21,185$

$83844.99 \quad 33.952$.
$6884.40 \quad .181$.

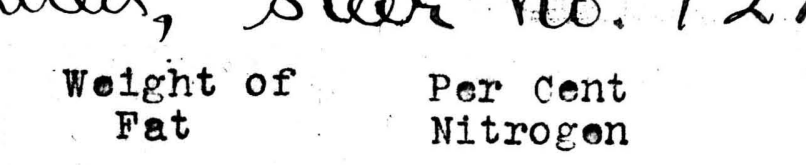

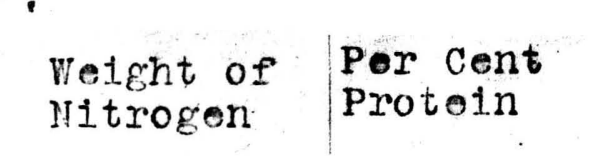

$\begin{array}{lllll}480.03 & 2.929 . & 77.33 & 18.310 .\end{array}$

231. $29 \quad 2,929$.

$\begin{array}{ll}1151.62 & 3.500 . \\ 1862.94 & 3.261\end{array}$

$\begin{array}{ll}1862.94 & 3.261 . \\ 3473.52 & 3.283\end{array}$

8060.50

$1143.99 \quad 3,500$.

$12678.01 \quad 2,842$

$436.48 \quad 3.283$

$3162.94 \quad .617$

$\begin{array}{ll}561.40 & 3.500 . \\ 160.82 & 2.453\end{array}$

$3838.86 \quad 3.008$

$17970.31 \quad .396$

$1447.78 \quad 3.500$

$23256.95 \quad 2.187$

$1922.35 \quad 1.924$

$2210.46 \quad 1.924$.

$\begin{array}{rr}7.20 & 3.500 \\ 4140.01 & 1.930\end{array}$

$10151.24 \quad 3.105$.

$38519.90 \quad .644$

$4311.99 \quad 3.500$

$\begin{array}{ll}52983.13 & 2.407 .\end{array}$

$\begin{array}{ll}77.33 & 18.310 \\ 37.26 & 18.310\end{array}$ 190. $26 \quad 21.875$

$\begin{array}{rr}304.85 & 20.381 . \\ 1393.57 & 20.520\end{array}$

$\begin{array}{rr}1393.57 & 20.520 . \\ 6170 & 3.860\end{array}$

$\begin{array}{rr}61.70 & 3.860 \\ 189.00 & 21.875\end{array}$

$1644.27 \quad 17,763$.

$175.12 \quad 20.520$

\begin{tabular}{l}
$24.21 \quad 3.860$ \\
\hline
\end{tabular}

92. $75 \quad 21.875$.

$\begin{array}{ll}292.08 & 15.331 . \\ 013.27 & 18.800\end{array}$

$81.01 \quad 2.480$

239. $19 \quad 21.875$.

$1333.47 \quad 13.669$.

$77.54 \quad 12.030$

$89.16 \quad 12.030$

\begin{tabular}{l|l|l}
1.19 & 21.875
\end{tabular}

$167.89 \quad 12.063$.

$13.16 \quad 1.131$.

$736.83 \quad 19.410$.

306. $50 \quad 4.025$.

712.39 21,875.

$3755.72 \quad 15,044$.
Weigrit of
Protein

$\begin{array}{ll}\text { Veight of } & \text { Per cent } \\ \text { Agh } & \text { Phosphonis }\end{array}$
$483.31 \quad 733$.

232 87

$1189.13 \quad 27,108$.

$1905.31 \quad 16,070$.

$385.63 \quad . \quad .153$.

$118125 \cdot 27.108$.

109450

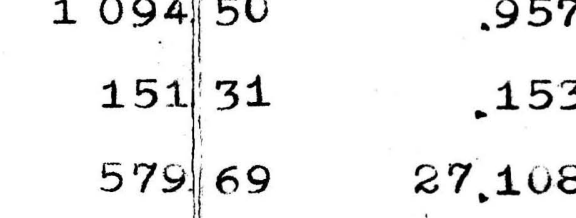

182550

6332
506
31

$1494 \mid 94 \quad .133$

833419

\begin{tabular}{l|l}
484 & 63 \\
55 & 25
\end{tabular}

104
104
82

$17105 / 19$

191562

445244
2347325 $\begin{array}{rrr}19.35 & .142 . & 3.75 \\ 9.32 & .142 . & 1.81 \\ 1473.59 & 4.806 . & 261.25 \\ 1502.26 & 2.854 . & 266.81 \\ 406.23 & .191 & 80.07 \\ 15.30 & .030 & 3.00 \\ 1463.83 & 4.806 . & 259.52 \\ 1885.36 & .591 . & 342.59 \\ 51.05 & .191 . & 10.19 \\ 6.00 & .030 . & 1.18 \\ 718.36 & 4.806 . & 127.36 \\ 775.41 & 1.165 . & 138.73 \\ 317.66 & .185 . & 62.32 \\ 27.21 & .024 . & 4.91 \\ 1852.56 & 4.806 . & 328.44 \\ 2197.43 & .649 . & 395.67 \\ 20.15 & .095 . & 3.83 \\ 23.17 & .095 . & 4.40 \\ 9.22 & 4.806 . & 1.63 \\ 52.54 & .113 . & 9.86 \\ 5.09 & .012 . & 87 \\ 814.44 & .182 . & 160.16 \\ 86.09 & .034 . & 16.17 \\ 5517.56 & 4.806 . & 978.20 \\ 6418.09 & .740 . & 1154.53\end{array}$ 
Carcass

gable XXX.

steer no. 121

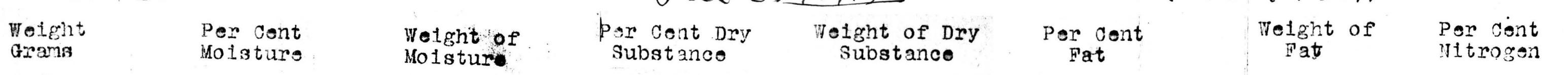

$109864 . \quad 54.720$

Hndquartors Loan

carcass Lean

$60117.86 \quad 45.280$

$\begin{array}{rr}59 \\ 119452.98 & 39.672 .8\end{array}$

$198002 . \quad 60.38 \%$

$45554 . \quad 43.665 . \quad 119450.84-56.334$

$19891.81 \cdot 85,622$

$\begin{array}{rr}6838.46 & 71.293 \\ 26730.28 & \end{array}$

(a)

cindquartons Bone

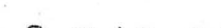

70.347

3roass Bono

6035.57

20354.29 .653

tal oreass

161165.97

70.347

$1943.60 \quad 37.705$

$\begin{array}{ll}688.98 & 37.705\end{array}$

tal Head (excl. tseth and horns)

Ta11

$\begin{array}{ll}519.02 & 70.347 \\ 59.503 .\end{array}$

$151.60 \quad 37.705$

$158.23 \quad 37.705$

a.11 3one

rotal Tail

$128.10 \quad 70.347$

sot (isss HоOеs) вопо

$32.46 \quad 70.347$

29.65

43.341
29.653.

$4976.14 \quad 29.394$.

$\begin{array}{ll}28805.02 & 11.517 \\ 78551.16 & 21.436\end{array}$

$25562.19 \quad 43,610$.

$32293.07 \quad 2,485$.

$4.0721 .54 \quad 80,992$

$42444.31 \quad 2.761$.

$66383.73 \quad 62.701$.

19.865 .91

58385.81

14.1818.43

$35549.15 \quad 21.185$

$180484.03 \quad 32,646$.

3.500
4393.64

3.500

$\begin{array}{rrr}32,646 . & 111535.75 & 2,473 . \\ 18,183 . & 567.31 & 2,929 .\end{array}$

$\begin{array}{ll}176.40 & 18.183 . \\ 417.02 & 18,183\end{array}$

$\begin{array}{ll}5975.98 & 21,185 \\ 7569.40 & 19.402\end{array}$

$\begin{array}{rr}201.10 & 2.929 \\ 1799.67 & 3.500\end{array}$

$\begin{array}{llll}95.77 & 18.183 & 2468.08 & 3.310\end{array}$

$21.87 \quad 18.183$.

$30390-21.185$

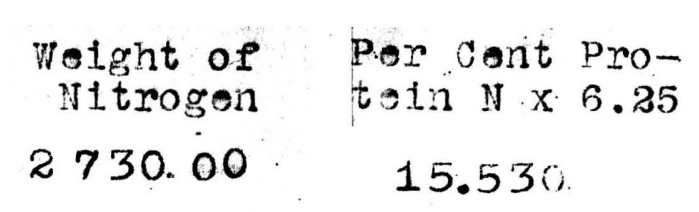

$\begin{array}{ll}2730.00 & 15.530 \\ 2736.83 & 19.410 \\ 5466.83 & 17.200\end{array}$

$\begin{array}{ll}5466.83 & 17.260\end{array}$

$907.78 \quad 12.456$

$306.50 \quad 4.025$.

$1214.28 \quad 8.150$

$712.39 \quad 21.875$

712.39
1768.69
8

15.456

32. $39 \quad 18,310$

297. 33.21 .875

$421.10 \quad 20.682$

$170 \quad 18,310$

$15.12 \quad 21875$.

24. $26 \quad 20.381$

$242.55 \quad 21.875$

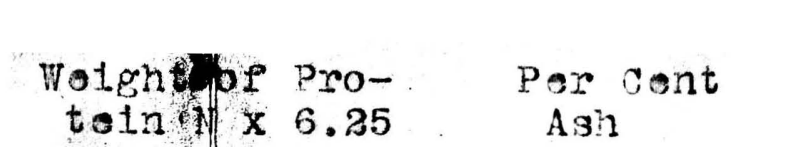

$\begin{array}{ll}1706) & .606 \\ 17100 & .924 .\end{array}$

$567) .65$
191.62

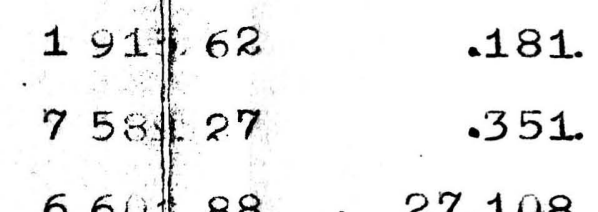

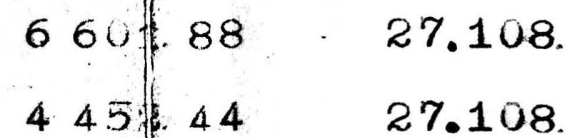

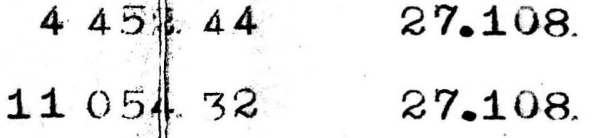

281.28

$5 \% .13 \quad .733$.

$185.31 \quad 27.108$

$263.88 \quad 18.341$.

$\begin{array}{rr}4.5 & .733 \\ 1.53 & .733 \\ 50 & 27.108\end{array}$

27.108. $\begin{array}{ll}3416.69 & .924 . \\ 5671 .\end{array}$

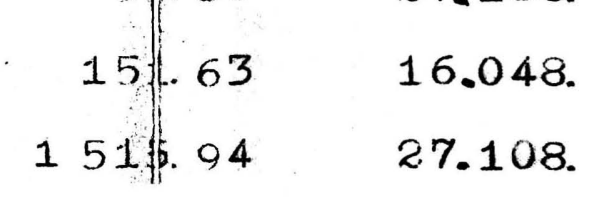

7otght of Por dont

$731.38 \quad .138$

$\begin{array}{rl}814.44 & .18 \% \\ 1545.82 & .154 .\end{array}$

$241.07 \quad .104$.

$\begin{array}{rr}327.16 & .068 \\ 8181.20 & 4.806 .\end{array}$

$5517.56 \quad 4.806$.

$13698.76 \quad 4.806$.

15571.74 .819$.

\begin{tabular}{rr}
$2302.22 \quad 4.806$. \\
\hline 333.20
\end{tabular}

$\begin{array}{ll}1.86 & .142 .\end{array}$

$\begin{array}{rr}.43 & .142 \\ 117.11 & 4.866\end{array}$

$119.40-4.806$.

119.40
.878 .58
$86.09-.034$

$\begin{array}{rr}22.87 & .142 . \\ 8.11 & .142 .\end{array}$

$2333.20 \quad 3.25 \%$

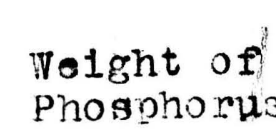

144.79

160.16
304.96

304.96
47.48

16.17
63.65

1450.45

978.20
2428.65

2428.65

4.43

408.27

$\begin{array}{rrrr}421.54 & 19.927 . & 148.26 & 3.261 . \\ 4875.05 & 21.185 & 1468.12 & 3.500\end{array}$

.08
20.76
21.20

333.06

\begin{abstract}
4.806
\end{abstract}


Iotal Annimal Iable XXX continued \&ter No.12i

Total Animal Bono.

lotal Antmal pat (Lpess offar).

War and Hidio

oppal pat

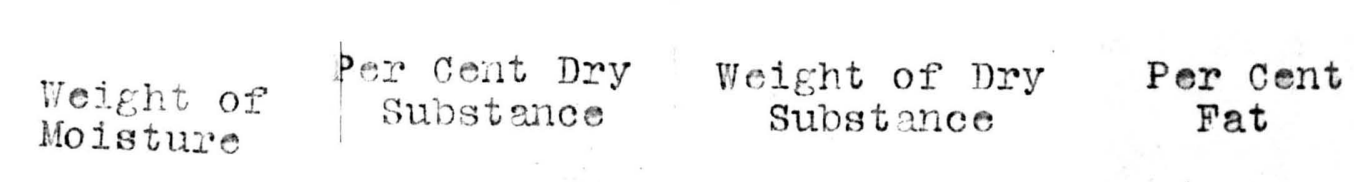

$\underset{\substack{\text { Worgent } \\ \text { Fat }}}{\substack{\text { Per cont } \\ \text { MIt coogen }}}$

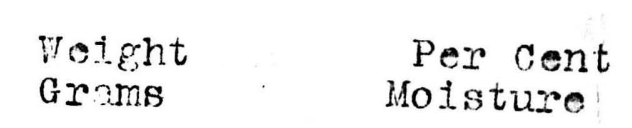

3.500 .

66391.

201376.

$\begin{array}{lllll}19686.92 & 70.347 . & 46704.08 & 21.185 .\end{array}$

14064.94

$66822.62 \quad 62,154$

58597.46

1.324.

$27455.39 \quad 70.870$

$79823.33 \quad 21.382$

$43057.81 \quad 2.764$.

$1934.80 \quad 4.969$

$17727.20 \quad 40.236$

27376

24433.

$2605.37 \quad 90.483$.

4770.63

$1.473 .90 \quad 5.534$.

$24094.99 \quad .273$.

$1969.06 \quad 53.919$.

(1)

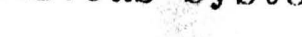

63.95

5382.35 none

nome

.273.
3.255.

$2961.76 \quad 36.045$

$1669.24 \quad 19.692$.

$710 . \quad 68.35$

$485.33 \quad 31.643$

19.499 .

492903

66.756

$26550.78 \quad 33,244$

$13222.22 \quad 17.496$

2.005

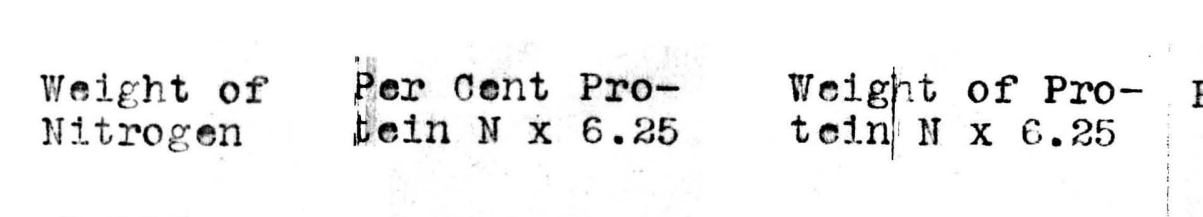

$\underset{\text { Ash }}{\text { Per cent }}$

Weight of
Ash $\quad \begin{gathered}\text { Por cont } \\ \text { Phosphorus }\end{gathered}$

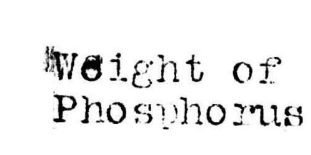

$\begin{array}{llll}2323.69 & 21,875 & 14523.06 & 27.108 .\end{array}$

$\begin{array}{rrr}1248.37 & 8.275 . & 7902.34\end{array}$

27.108.
.356.

17997.27

4.806.

B 19074

$\begin{array}{lll}565.65 & 17.280 & 34785.31\end{array}$

$74.74 \quad 34.590$.

$\begin{array}{ll}74.74 & 1.710 .\end{array}$

$795.29 \quad 20.340$

$66.57 \quad 9.738$.

$106.88 \quad 14.430$.

10259.38

797.51

$\begin{array}{rr}2632.10 & 12.531 \\ 16,019\end{array}$

$4 \$ 170.56$

4.16 .06

.758

1570.55

.069

190.74
65.30

74.38

4984.44
78950.63

.248.
-502.

35.32

.056

16.61

60.59 .028.

37. 103.

11. 09

351.35

20645.58

.748.

6. 84

4. 41

7. 87 
Fonquarters gable $X X X I_{\text {ster no. }} 48$.

Shins Lean
Shins Fat

shins Bone

rotal out of Shins

Plates Loan

Plates Fat

rotal Gut of Plates

Ghuoks Lexn

Shuoks Pat

Thuoks Bons

ivocks Lean

iecks Fat

rotal cut of rook

Risbs cut

Ribs Fat

Ribs bone

Potal cut of R1bs

Porequarter Lean

proquart or Fat

Total porecuarters

\begin{tabular}{|c|c|c|c|c|c|c|c|}
\hline 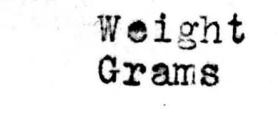 & $\begin{array}{l}\text { Ber cent } \\
\text { Moisture }\end{array}$ & $\begin{array}{l}\text { Wolight of } \\
\text { Molsture }\end{array}$ & $\begin{array}{l}\text { Psir cont rory } \\
\text { subst ance }\end{array}$ & $\begin{array}{l}\text { Tetgight of pry } \\
\text { substance }\end{array}$ & $\begin{array}{l}\text { Porr oont } \\
\text { Fat }\end{array}$ & $\begin{array}{l}\text { Wetgight of } \\
\text { pat }\end{array}$ & $\begin{array}{l}\text { Por cont } \\
\text { witrogon }\end{array}$ \\
\hline 7973. & 57.840 & 4614.48 & 42.160 & 3363.52 & 23.470 & 1872.44 & \\
\hline 1908. & 57.840. & 1103.59 & 42.160 & 804.41 & 23.470. & 447.81 & 2.853 \\
\hline 6008. & 20.710 & 1244.26 & 79.290 & 4763.74 & 24.344. & 1462.59 & $3.2 \cup 2$ \\
\hline 15894. & 43.805. & 6962.33 & 56.195. & 8931.67 & 23.800 & 3782.84 & 2,985 \\
\hline 27690. & 30.150 & 8348.54 & 69.850 & 19341.46 & $61,110$. & 16921.36 & 1.308 \\
\hline 38062. & 30.150 & 11475.69 & 69.850 & 26586.31 & 61.110. & 23259.69 & 1.308 \\
\hline 6856. & 37.730 & 2586.77 & 62.270 & 4269.23 & 19.567. & 1341.51 & $z_{\triangleleft}, 999$ \\
\hline 72608 & 30.866 & 22411.00 & 69.134. & 50197.00 & 57.187 & 41522.56 & 1.468. \\
\hline 69912. & 49.670 & 34725.29 & 50.330 & 35186.71 & 34.950. & 24434.24 & 2.267 \\
\hline 33068. & 49.670 & 16424.88 & 50.330 & 16643.12 & 34.950. & 11557.27 & 2.267 \\
\hline 15284. & 27,780 & 4245.90 & 72.220 & 11038.10 & 18.655. & 2851.23 & $3,527$. \\
\hline 118264. & 46.841. & 55396.07 & 53.159. & 62867.93 & 32.844 & 38842.74 & 2.430 \\
\hline 2500 & 49.670 & 1241.75 & 50.330 & 1258.25 & $34.950=$ & 873.75 & 2.267 \\
\hline 1478. & 49.670. & 731.14 & 50.330 & 740.86 & 34.950. & 514.46 & 2.267 \\
\hline 858. & 27,780 & 238.35 & 72.220 & 619.65 & $18,655$. & 150.06 & 3.527. \\
\hline 4830. & 45.781 & 2211.24 & 54.219. & 2618.76 & $31,848$. & 1538.27 & 2.491 \\
\hline 24250 & 56.860 & 13788.55 & 43.140 . & 10461.45 & 24.790 & 6011.58 & 2,679 \\
\hline 27010 & 15,810 & 4270.28 & 84.190 & 22739.72 & 81.370. & 21978.04 & 0.431 \\
\hline 7294. & 26.750 & 1951.15 & 73.250 & 5342.86 & 18.359. & 1339.11 & 3.303. \\
\hline 58554. & 34.174 & 20009.98 & 65,826 & 38544.03 & 50,088 & 29328.73 & 1.720 \\
\hline 132330 & 47.396 & 62718.61 & 52.604 & 69611.39 & 37.870 & 50113.37 & 2.177 \\
\hline 101520 & 33.50 & 34005.58 & 66,500 & 67505.42 & 56.890. & 57757.27 & 1.430 \\
\hline 36300 & 28.28 & 10266.43 & $71,720$. & 26033.57 & 19.682. & 7144.50 & 3.328. \\
\hline 70150 & 39.604. & 106990.62 & $60,396$. & 163159.39 & 42,575. & 115015.14 & 2.073 \\
\hline
\end{tabular}

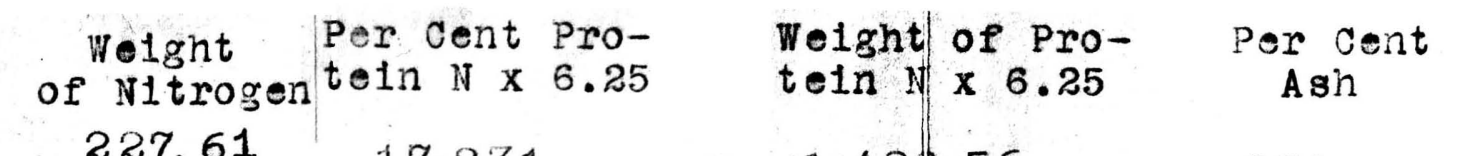

$\begin{array}{rr}227.61 & 17.831 \\ 54.44 & 17.831 \\ 192.38 & 20.013\end{array}$

$\begin{array}{ll}192.38 & 20.013 \\ 474.43 & 10.656\end{array}$

$474.43 \quad 18.656$.

$362.19 \quad 8.175$.

$497.85 \quad 8.175$.

$\begin{array}{rr}205.61 & 18.744 \\ 1065.65 & 9.175\end{array}$

$1065.65 \quad 9.175$

$1584.91 \quad 14.169$

59.67 14.169

$\begin{array}{rr}539.07 & 22.044 \\ 2873.63 & 15.180\end{array}$

$63 \quad 15.188$

$56.68 \quad 14.169$

$33.37 \quad 14.169$

30. $26 \quad 22.044$

$120.31 \quad 15.569$

$649.66 \quad 16.744$

$116.41 \quad 2.694$

$240.92 \quad 20.644$

$1006.99 \quad 10.750$

$2881.05 \quad 13.606$

1451.728 .938

$1268.24 \quad 20.800$

$5601.01 \quad 12.950$

$120038 \quad 33.040$

$296 \% 19 \quad 13.005$

311. $56-421$

$128.06 \quad 20.220$

$666031 \quad 2.291$

$990 \% .69 \quad .693$

$17966.19 \quad 4.161$

$.354 .25 \quad .693$

18\$. $13 \quad 27.53$

$\begin{array}{rr}75.94 & 8.689\end{array}$

$407 \% 38 \quad .827$

$1509.75 \quad 29.410$

$629 \$ .69 \quad 4.078$

$18000.56 \quad .787$

9077.25
$755.50 \quad 27.430$

$35006.31 \quad 4.242$
Metght of
Asin $\quad \begin{gathered}\text { Per cent } \\ \text { Phosphorus }\end{gathered} \quad \begin{aligned} & \text { Wetght of } \\ & \text { Phosphorus }\end{aligned}$

$\begin{array}{rr}66.14 & .148 \\ 15.82 & .142 \\ 1985.04 & 6.173 \\ 2067.00 & 2.422 \\ 116.57 & .064 . \\ 160.24 & .064 . \\ 1386.28 & 3.772 \\ 1663.09 & .414 . \\ 484.49 & .123 \\ 229.16 & .123 . \\ 4207.69 & 5.073 . \\ 4921.34 & .763 \\ 173.25 & .123 . \\ 10.20 & .123 . \\ 236.21 & 5.073 . \\ 419.66 & 1.002 \\ 200.55 & .150 \\ 41.87 & .021 . \\ 2145.17 & 5.416 . \\ 2387.59 & .748 . \\ 1041.00 & .117 . \\ 457.29 & .074 . \\ 9960.39 & 5.078 . \\ 11458.68 & .767\end{array}$

11.33
2.71
370.87

384.91

17.72

24. 36

258. 61

300.69
85.99

40.67

775.36

902.02

3. 08

1. 81

48. 42

36.38

395.04

75.22

1843.41

2073.13 
Hindquarters gable XXXI continued, stur.ho.48.

Shanks Lean

shanke none

lotal cut of Shanks

Rounds Lean

Rounds Fat

Total cut of Rounds

Rurigs Loan

Rumps Fat
Rumps Bono

lotal cut of Rumps

oin Lean

win Fat

rotal out of Loin

Lanks Lean

lanks. Fat

anks Bone

tal out of $\mathrm{Pl}_{1 \text { anks }}$

at of kidnes

i.ndquarters Fat $^{2}$

ndguartors 300

estal Hindquartors

\begin{tabular}{|c|c|c|c|c|c|}
\hline 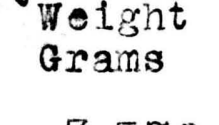 & Moisture & Molsture & subst anoe & 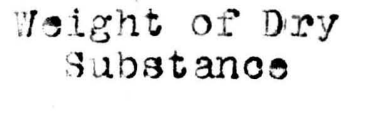 & Fat \\
\hline 3570 & & & 42.160 & 1505.11 & 23.470 \\
\hline 1440. & 57.840 & 832.90 & 42.160 & 607.10 & 23.470 \\
\hline 6524. & $20.71 \mathrm{c}$ & 1351.12 & 79.290. & 5172.88 & 24.344. \\
\hline 11534. & $36.8 .3 \%$ & 4248.91 & 63.162. & 7285.09 & 23.964. \\
\hline 50284. & $64.43 c$ & 32397.98 & $35,570$. & 17886.02 & 13.420 \\
\hline 19520 & $2.7 .75 \mathrm{c}$ & 5416.80 & 72.250 & 14103.20 & 67.350. \\
\hline 6318. & 2.3 .164 & 1463.25 & 76.840. & 4854.75 & 32,479 \\
\hline 76122. & 51.59 & 39278.03 & 48.401. & 36843.97 & $28,831$. \\
\hline 7088. & 36,916 & 2616.18 & 63.090. & 4471.82 & 52,670 \\
\hline 8998. & 36.91 .6 & 3321.16 & $63,090$. & 5676.84 & 52.670 \\
\hline 3520. & 26.299 & 925.41 & 73.710 & 2594.59 & 35.688. \\
\hline 19606. & 35.000 & 6862.75 & 64.997. & 12743.25 & $49,621$. \\
\hline 43154. & 61.78 & 26660.54 & 38,220 & 16493.46 & $18.26 \bullet$ \\
\hline 43826. & $12.60 \mathrm{r}$ & 5522.08 & 87.400 & 38303.92 & 84.760. \\
\hline $9 \cdot 363$. & 21.55 & 2018.80 & 78.450 & 7349.20 & 29.603. \\
\hline 96348. & $35.4=$ & 34201.42 & 64.502. & 62146.58 & 49.612 \\
\hline 6748 & $30.15 !$ & 2034.52 & 69.850. & 4713.48 & 61.110 \\
\hline 18706. & $30.15 i$ & 5639.87 & 69.850. & 13066.14 & 61.110. \\
\hline 80 & 37.73 & 30.18 & 62.270 & 49. 82 & 19.567. \\
\hline 25534. & $30.17 x$ & 7704.57 & 69.826. & 17829.44 & 60.980 \\
\hline 17170 & 3.760 & 645.59 & 96.240 & 16524.41 & 94.710. \\
\hline 110844. & $5 y .348$ & 65744.11 & 40,660 & 45069.89 & 21.041 \\
\hline 109660. & 19.500 & 21378.35 & 80.500 & 88281.61 & 75.750. \\
\hline 25810 & 22.438 & 5788.76 & 77.570 & 20021.24 & 29.776 \\
\hline 246314. & 37.721 & 92941.26 & 62.279 & 153372.74 & 46.312. \\
\hline
\end{tabular}

\begin{tabular}{|c|c|c|c|c|c|}
\hline $\begin{array}{l}\text { Weight of } \\
\text { Fat }\end{array}$ & $\begin{array}{l}\text { som cont } \\
\text { fitrogen }\end{array}$ & $\begin{array}{l}\text { Woight of } \\
\text { Witrogon }\end{array}$ & $\begin{array}{l}\text { Por cont Pro- } \\
\text { Poin } \mathrm{N} \times 6.26\end{array}$ & 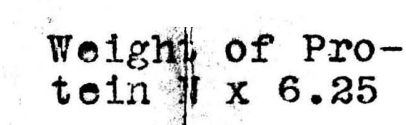 & $\begin{array}{l}\text { Por Cont } \\
\text { Ash }\end{array}$ \\
\hline 837.88 & 2.853 & 101.85 & $1,9.831$ & 636.56 & .829 \\
\hline 337.97 & 2.853 & 41.08 & 17.831. & 25675 & 829. \\
\hline 1588.20 & 3.202 & 208.90 & 20.013 & 130563 & 33.040. \\
\hline 2764.05 & 3.050 & 351.83 & 19.063. & 2198.94 & 19.047 \\
\hline 6748.11 & 3.278 & 1648.31 & 20.488 & 10307.94 & 1,015 \\
\hline 13146.72 & .765 & 149.33 & 4.781. & 931.31 & .251. \\
\hline 2052.02 & 2.124 & 134.19 & 13.275 & 83f. 69 & 27.070 \\
\hline 21946.85 & 2,539 . & 1931.83 & 15.869. & $1207+94$ & 2.982. \\
\hline 3733.25 & 1.587. & 112.49 & 9.919. & $70 \$ 06$ & .509. \\
\hline 4739.25 & 1.587. & 142.80 & 9.919. & $89 \$ 50$ & .509 \\
\hline 1256.22 & 2.294 & 80.75 & 14.338. & 504.69 & $20,650$. \\
\hline 9728.72 & 1.714. & 336.04 & 10.713 & 210.25 & $4,125$. \\
\hline 7879.92 & 2.981 & 1286.42 & 18.631. & $804: 02$ & .956. \\
\hline 37146.92 & .426. & 186.70 & 2.663. & 1160.88 & .146. \\
\hline 2773.21 & 2,820 & 264. 18 & 17.625 & 165.13 & 26.090 \\
\hline 47800.05 & 1.803. & 1737.30 & 11.269. & $1085 \% .03$ & 3.031. \\
\hline 4123.70 & 1.308. & 88. 26 & 8.175. & 55.63 & .421. \\
\hline 11.431 .24 & 1.308. & 244. 67 & 8.175. & 152: 19 & .421 \\
\hline 15. 65 & 2.999 & 2. 40 & 18.744. & $1 \$ .00$ & 20.220 \\
\hline 15570.59 & 1.313. & 335.33 & 9.206. & 209.82 & .483. \\
\hline 16261.71 & .239 & 41.04 & 1.494. & $25 \% .50$ & .126. \\
\hline 23322.86 & 2.926 . & 3237.33 & 18.288. & 20 23*. 31 & .918. \\
\hline 83063.81 & .735. & 805.62 & 4.594. & $503 \% .13$ & .247 \\
\hline 7685.30 & $2,675$. & 690.42 & 16.719 & 4314.13 & 27.326. \\
\hline 14071.97 & 1,922 & 4733.37 & 12.013. & $295 \% 56$ & $3,386$. \\
\hline
\end{tabular}

\begin{tabular}{|c|c|c|}
\hline $\begin{array}{l}\text { Welgint of } \\
\text { Ash }\end{array}$ & $\begin{array}{l}\text { Por cont } \\
\text { Phosphorus }\end{array}$ & $\begin{array}{l}\text { Woitht o } \\
\text { Phosphor } \\
5\end{array}$ \\
\hline 29.59 & .142 & \\
\hline 11.94 & .142 & \\
\hline 2155.43 & 6.173. & 402.73 \\
\hline 2196.96 & 3.553. & 409.84 \\
\hline 510.38 & .192. & 96.55 \\
\hline 49.00 & .027 & 5. 27 \\
\hline 1710.28 & 5.020. & 317.16 \\
\hline 2269.66 & .550 & 418.98 \\
\hline 36. 08 & .093 & 6. 59 \\
\hline 45. 80 & .093. & 8. 37 \\
\hline 726.88 & 3.891. & 136.96 \\
\hline 808.76 & .775 & 151.92 \\
\hline 412.55 & .174. & 75.09 \\
\hline 63.99 & .023 & 10.08 \\
\hline 2444.11 & 4.805. & 450.13 \\
\hline 2920.65 & .556 & 535.30 \\
\hline 28. 41 & .064 & 4. 32 \\
\hline 78.75 & .064. & 11. 97 \\
\hline 16. 18 & 3.772 & 3.02 \\
\hline 123.34 & .076 & 19. 31 \\
\hline 21.63 & .016 & 2. 75 \\
\hline 1017.01 & .169 & 187.62 \\
\hline 271.11 & .037 & 40.48 \\
\hline 7052.88 & 5.076. & 1310.00 \\
\hline 8341.00 & .624. & 1538.10 \\
\hline
\end{tabular}


C'arcass.

Stuer no. 48

Poroquarters Loan

Hindquarters

Porequarters Fat

Hindquarters Fat

Forequarters во:

ifindquart ors Bono

Jarc ass Bone

rotal carcass

Hexa Lean

Head Bone

rotal Head (oxc1. tooth and horns)

Palli. wat

Pa:il Bono

20tal rati

7rat, Less hoors.

\begin{tabular}{|c|c|c|c|c|c|c|c|c|c|}
\hline & & & & & & & & & \\
\hline $\begin{array}{l}\text { Weight } \\
\text { arams }\end{array}$ & 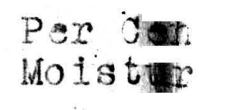 & $\begin{array}{l}\text { Wrotght of } \\
\text { Molisture }\end{array}$ & 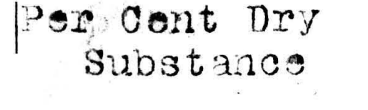 & $\begin{array}{l}\text { Wosight of } \\
\text { Dry Substance }\end{array}$ & $\begin{array}{l}\text { Pore gont } \\
\text { Fat }\end{array}$ & $\begin{array}{l}\text { Booght of } \\
\text { pat }\end{array}$ & 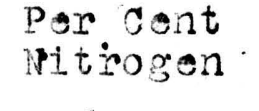 & $\begin{array}{l}\text { "rosight of } \\
\text { ritrogonon }\end{array}$ & 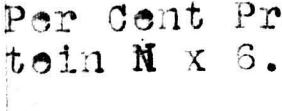 \\
\hline 132330. & 4734 & 62718.61 & $52,604:$ & 69611.39 & 37.370 & 50113.37 & 2.177 & 2881.05 & $13,6 \cup 6$ \\
\hline 110844. & 5934 & 05744.11 & 40,660 . & 45069.89 & 21.041. & 23322.86 & 2.926 & 3237.33 & 18.280. \\
\hline 243174 & 5284 & 12849272 & 47,160 & 114681.28 & $30,199$. & 73.436 .23 & 2,516 & 6118.38 & $15,7,25$ \\
\hline 101520. & $335 \pi$ & 34005.58 & 66,500 & 67514.42 & 56.890. & 57757.27 & 1,430 & 1451.72 & 8.93. \\
\hline 109660 & $195 \mathbf{C}$ & 21378.39 & 80,500 & 88281.61 & 75.750 & 83063.81 & .735 & 805.62 & 4.594. \\
\hline 211180 & 2623 & 55383.97 & 73,770 & 155796.03 & 66.680. & 140821.08 & 1069 & 2257.34 & $6,681$. \\
\hline 36300 & 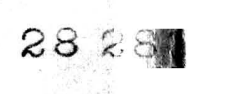 & 102.66 .43 & 71,720 & 26033.57 & 19.682. & 7144.50 & $3,328$. & 1268.24 & 20.800 \\
\hline 25810 & 224 電 & 5788,76 & 77.570 & 20021.24 & 29.776 & 7685.30 & 2,675 & 690.42 & 16.719 \\
\hline 62110 & 258 形 & 16055.19 & 74.150 & 46054.81 & 23.861. & 14829.80 & 3,057 & 1898.66 & 19,106 \\
\hline 516464. & 3874 & 199931.88 & 61.288 & 316532.12 & $44,35 \%$ & 229087.11 & 1,989 & 10274.38 & 12.431 \\
\hline 2 998 & 5784 & 1734.04 & 42,160 & 1263.96 & 23.470 & 703.63 & 21853 & 85.53 & 17.831. \\
\hline 1338. & 5784 & 773.90 & 42,160 & 564.10 & 23.470 & 314.03 & 2,853 & 38.17 & 17.831. \\
\hline 8942. & 3705 & 3313.01 & 62.950. & 5628.99 & 11.519. & 1030.03 & 3.429. & 306.62 & 21.431. \\
\hline 13278. & 4383 & 5820.95 & $56,161$. & 7457.05 & $15,422$. & 2047.69 & $3,241$. & 430.32 & 20.256 \\
\hline 190. & 5784 & 109.90 & 42,160 & 80. 10 . & 23.470 & 44.59 & 2.853 & 5.42 & 17.831. \\
\hline 72. & 5784 & 41.64 & 42,160 & 30.36 & 23.470 & 16. 90 & $2,853$. & 2.05 & 17.831. \\
\hline 566. & 370 教: & 209.70 & $62,950$. & 356.30 & 11,519 & 65. 20 & 3.429 & 1.9. 41 & 21.431. \\
\hline 828. & 436 触 & 361.24 & 56.378 & 466.76 & 15.301. & 126.69 & 3.246 & 26.88 & 20.288. \\
\hline & & & $62,950$. & 4793.01 & $11,519$. & 877.06 & 3.429. & 261.08 & 21431. \\
\hline
\end{tabular}

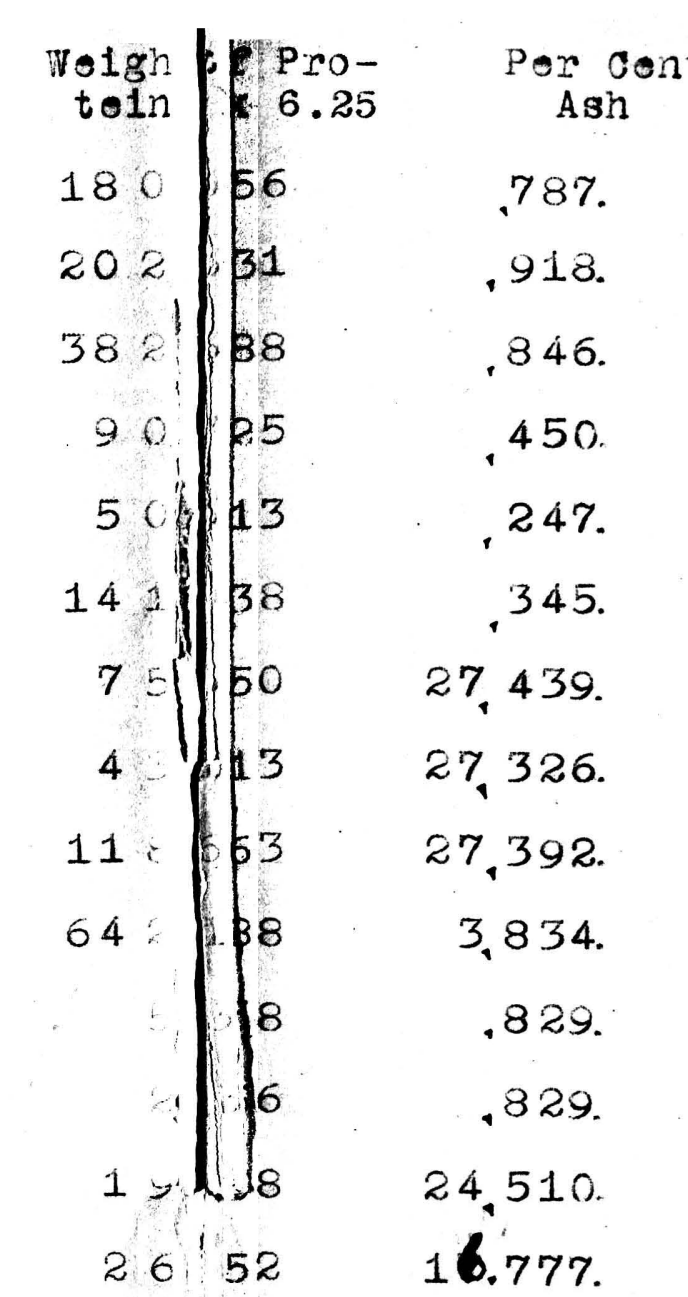

Hoight
of Ash

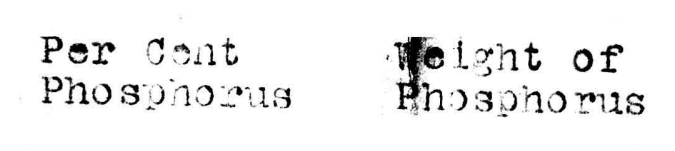

1041.00
1017.01

1017.01
2058.01

457. 29

271.11

728.40

9960.39

7052.88
17013.27

19799.68

24. 85 $11.09 \quad .142$
142.68 191.68
2

$60 \quad, 142$.
138.73
140.91

138. $73 \quad 4,635$

\begin{tabular}{l}
$140,91-3,213$. \\
\hline 866.19
\end{tabular}

1866.19
187.62

342.12
75.22

40.48

115. 70

1843.4

3153.41

3611.23 
Of otal Aunpual

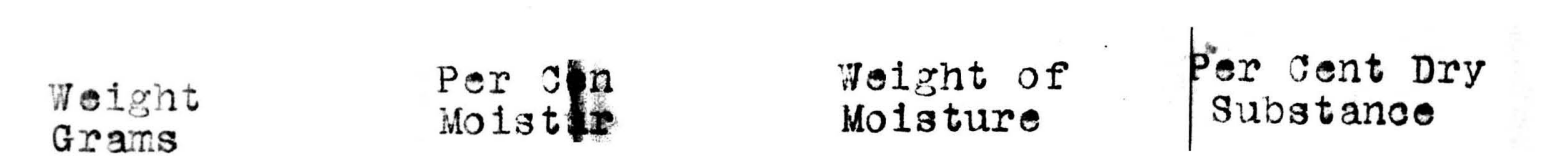

Total AnImal Bone

rotal AnIma1 pat (Less offal

rotal Animal

Ha1r and H1de

ffal Fat

diroulatory System

Resplratory Syston

vorvous Systen

Igostive and Bxoratory Syst an

Fotal An1ma
Table XXXII continued, Ster to. 48 .

\begin{tabular}{|c|c|c|c|c|c|c|c|c|c|c|c|}
\hline arams & & & & & & & & & & & \\
\hline 79238 & $23.2 \%$ & 22398.89 & 71.730 & 56833.11 & 21.206. & 16802.09 & 3.137. & 2 485.77 & 19.606. & 15535.06 & 26.769. \\
\hline 12.590 & 20.446 & 56199.51 & 73.560 & 156390.49 & 66.396. & 141152.01 & 1.081. & 2297.56 & 6.756 & $143^{3} \mathrm{~h}_{\mathrm{p}}, 75$ & .348 \\
\hline 46362. & $5 \approx .4 t E$ & 130336.66 & 47.095 & 116025.34 & 30.112 & 74184.45 & 2.520 & 6209.33. & 15.750 & $3881 \% 31$ & .846 \\
\hline 41164. & $5 \% 34$ & 24385.55 & 40.760 & 16778.45 & 8.600 & 3540.10 & 5.308. & 2184.9 .9 & 33.175 & $1365 \$ 19$ & 1.197. \\
\hline $6183 \%$ & 6.228 & 3846.26 & 93.780 & 57990.74 & 92.090. & 56945.69 & .182 & 112.54 & 1.138 & $7 \$ 38$ & .093 \\
\hline 25634. & $7.41\}$ & 20355.96 & 20.590 & 5278.04 & mone & nome. & 3.158. & 809.52 & 19.738 & 50 卌 50 & .775 \\
\hline 6780 & 31.251 & z 117.44 & 68.769. & 4662.56 & 62.265 & 4221.54 & .983. & 66.65 & $6: 144$. & 448 & $.40 \%$ \\
\hline 10970 & $4 \therefore 4 k$ & 5421.37 & 50.580 & 5548.63 & 37.390. & 4101.68 & 1.957. & 214.68 & 12.231 & $13 / 75$ & .669 \\
\hline 774 & $6 \% .639$ & 533. 94 & 30.370 & 235.06 & 13.050. & 101.01 & 2.093. & 16. 20 & 13.081. & $1+25$ & 1.813. \\
\hline 9941. & 68.75 & 27463.00 & 31.241. & 12478.00 & $15,10 \%$ & 6033.70 & 2.049 & 818. 20 & 12.806. & $51 \% .75$ & .989 \\
\hline 284. & 40.47 & 293063.58 & 59.593. & 432220.42 & $42,340$. & 307082.27 & 2.098 & 15.215 .44 & $13,113$. & 950 ○中. 50 & 3.487 \\
\hline
\end{tabular}

$\underset{\substack{\text { Meight of } \\ \text { Asi }}}{\substack{\text { Por cont of } \\ \text { Phosphorus }}} \begin{aligned} & \text { Welght of } \\ & \text { Phosphiorus }\end{aligned}$ $\begin{array}{lll}21209.87 & 4.982 & 3947.01\end{array}$ $\begin{array}{lll}740.09 & .055 & 117.70^{\prime}\end{array}$ $\begin{array}{lll}2084.44 & .141 . & 346.65\end{array}$ $\begin{array}{lll}492.73 & .048 . & 19.7\end{array}$ $\begin{array}{rll}57.51 & .012 & 7.42 \\ 198.66 & .021 & 5.38\end{array}$ $\begin{array}{lll}27.58 & .076 & 5.16\end{array}$ $73.39 \quad .117 . \quad 12.83$ $\begin{array}{lll}14.03 & .425 . & 3.29\end{array}$ $394.90 \quad .202 .80 .54$ $\begin{array}{ll}5293.20 & .627 . \\ \end{array}$ 
TABLF 33.

STEER 18

PERCENTAGE COMPOSITION OF

SAMPLAS (AS FOR STTER I8).

Blood.-

Hide and Hair.

Total Skeleton.--

Circulatory system.

Respiratory System.

Nervous System.

Total Digest. and Exoret. System--

Liver. -

Kidneys--

offal Fat.

Kidney Fat.-
Shin, Shank, Head and Tail

Lean and Fat. -

Round and Rump Lean and Fat.

Mo1sture

81.290.

\begin{tabular}{l} 
Substanco \\
18.71 \\
\hline
\end{tabular}

\begin{tabular}{|l|l|l}
\hline 28.292 & 71.708 & 25.272. \\
\hline 56.503.
\end{tabular}

$-1$

56.503

$\frac{74.710}{68.830}$

67.106.

\begin{tabular}{l|l}
43.497. & 30.068
\end{tabular}

18.888

\begin{tabular}{l|l}
25.290 & 6.461 \\
\hline 31.170
\end{tabular}

12.475

68.990

17.625.

17.225.

75.046 .

\begin{tabular}{l|l}
32.894. & 16.037
\end{tabular}

10.938.

\begin{tabular}{l|l|l}
16.620 & 83.380 & 79.718
\end{tabular}

13.844.

14.831 .

$10: 044$

$67.433+89.956$

Chuck and Neok Lean and Fat.

66.503.

\begin{tabular}{l|l}
89.956 & 86.962 \\
\hline 32.567.
\end{tabular}

3.231

32.567

11.99

2.631

$66.480 \quad 33.52$

Rib Lean and Fat.--

$62.790 \quad 37.21$

14.068

20.119 .

19.438

\begin{tabular}{ll|l}
\hline 59.900 & 40,100 & 21,719
\end{tabular}

Flank and Plate Lean and Fat.

$52.512 \quad 47.488$

30.103

18.869

56.402

43.598

18.589.

821.

17.913.

.788

$18.850 \quad 5.721$ $\begin{array}{cccc}\% & \% & \% & \% \\ 688 . & .022 & 77.971 & \text { Pry } \\ \text { Dry } & 22.029\end{array}$

STEER 121

Total Animal Analyzed.- 
TABLE 34.

DISTRIBUTION OF CONSTITUENTS

IN FNTIRE ANIMAL.

wt. of constituent in animal analyxed, kilos

pt. of " "blood, kilos -

\%o of

Wt. of

\%o of

\%t. of

oft. of of

Tht. of " "

wt. of "

" " compared to animal.

in hide and hair, kilos.

in hide and hair compared to enimal.

in ciroulatory system,

compared to animal.

in respiratory system, kilos. compared to animal.

in nervous system, kilos.-

in total digest.and exoret. " total digest.and exoret.syste compared to animal. in liver, kilos.-

" " compared to animal.

in kidneys, kilos.

" " compared to animal.

in offal fat, kilos.- -

" " " compared to animal.

in kidney fat, kilos.-

in skeleton, kilos.

" " compared to animal.

head and tail, kilos.

in lean and fat of shin, shank, head, and

tall compared to anima.

and rump, kilos. compared to animal.
lean and fat of chuck and

in lean and filos. of chuok and compared to animal.

in lean and fat of rib, compared to animal.

In lean and fat of $10 \mathrm{in}$, kilos. compared to animal.
lean and fat of flank and

plate, kilos. - llank and compared to animal.
MOISTURE.

Stẹcr I2I. Steer $48 . \quad$ Steer I8. Steer I2I. Steer f8. Stero I2I. Steer 48. Steer I8. Steer I2I. \begin{tabular}{l|l|l|l|l|l}
1652 & .22 & 240045.13 & 293063.58 & 127740.78 & $25285 \% .87$
\end{tabular} \begin{tabular}{|l|lll|l|l|l}
\hline 126 & .40 & 19050.65 & 20355.96 & 2918.60 & 5382.35 & 5278.04
\end{tabular}

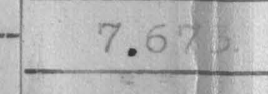

2.129

\begin{tabular}{c|ccccc}
\hline 167 & .81 & 17727.20 & 24385.55 & 8892.19 & 11934.80 \\
\hline
\end{tabular}

\begin{tabular}{l|l}
\hline 10.1 & 7.385
\end{tabular}

146.60

1969.06

$-235$

$\begin{array}{r}2 \\ 1 \\ \hline\end{array}$

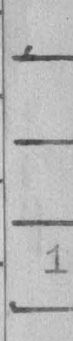

.820

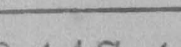

6.961.

2117.44

94

$961.76 \quad 5421.37$

.883.

.911.

$\begin{array}{lllll}1.234 . & 1.850 & .610 & .660 & 1.284 .\end{array}$

\begin{tabular}{|cccccc|}
\hline 48.00 & 485.33 & 538.94 & 225.00 & 224.67 & 235.06 \\
\hline .28 & .202 & .184. & .176 & .089 & .054. \\
\hline
\end{tabular}

$178.35 \quad 13222.22$

$-1$

\begin{tabular}{|cccccc|}
\hline .80 & 11.061 & 9.371 & & & \\
181.00 & 4809.13 & 5694.15 & 814.00 & 2225.87 & 2471.85 \\
\hline
\end{tabular}

FAT.

Steer I2I.

Steer 48.

Steer $48 . \quad$ Stoon

307082.87

1.221

16778.45

.123

000

000.

1473.90

$\therefore 000$

$3540-10$

$\begin{array}{lll}1.359 . & .974 . & 1.153 .\end{array}$

$\begin{array}{lll}.779 .96 & 1817.46 & 4221.54\end{array}$

$\begin{array}{lll}.432 . & 1.203 . & 1.375 .\end{array}$

$\begin{array}{lll}198.90 & 911.94 & 4101.68 \\ .365 . & .603 . & 1.336 .\end{array}$

$\begin{array}{lll}127.30 & .003 . & 1.336 .\end{array}$

$\begin{array}{lll}.234 . & .092 & 101 \\ 3.033\end{array}$

$\begin{array}{lll}3499.71 & 6958.72 & 6033.70\end{array}$

$\begin{array}{lll}6.426 . & 4.605 . & 1.965 .\end{array}$

$-1$

\begin{tabular}{cccccccccc}
1.05 & 2.003 & 1.943 & .637 & .880 & .572 & .167 & .220 & .113. \\
\hline 57.85 & 840.85 & 868.10 & 190.15 & 257.15 & 358.90 & 66.57 & 61.05 & 149.20 \\
\hline .34 & .350 & .296. & .149 & .102 & .083 & .122. & .044. & .049. \\
\hline
\end{tabular}

\section{-}
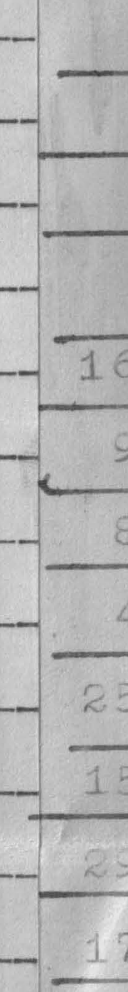

\begin{tabular}{|c|c|c|c|c|c|c|}
\hline (5) & & & & & & \\
\hline 24 & .48 & 326.08 & 645.59 & 2198.52 & 6945.92 & 16524.41 \\
\hline .14 & & .136 & .220 & 1.721. & 2.747 & 3.823. \\
\hline $164 \varepsilon$ & $\cdot 19$ & 19686.92 & $2239 p \cdot 89$ & $4177 \% .81$ & 46704.08 & 56833.11 \\
\hline 9.97 & & 8.201. & 7.643. & 32.705. & 18.470 & 13.149. \\
\hline
\end{tabular}
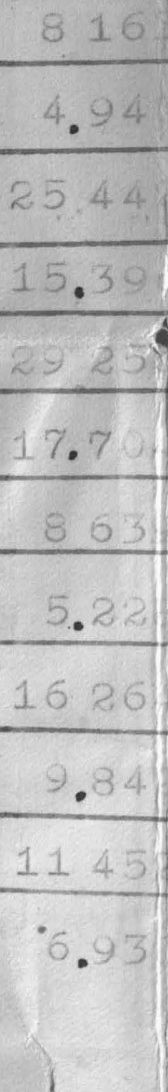

11534.53

11275.34

32.705.

3.847 .

3942.56

\begin{tabular}{|c|c|c|c|c|}
\hline 704.08 & 56833.11 & & & \\
\hline 470 & 13.149 & 27.033 & 9.307 & 5.472 \\
\hline 981.47 & 8218.66 & 1451.51 & 3366.77 & 4575.25 \\
\hline 761. & 1.901. & 2.665 & 2.228 & 1.490 \\
\hline 269.83 & $4213 \% .88$ & 5072.25 & 15133.44 & 28367.33 \\
\hline .389 & 9.749 & 9.313. & 10.014 & 9.238 \\
\hline $379 \cdot$ & 53828.94 & 6191.04 & 16964.63 & 37370.72 \\
\hline .223 & 12.454 & $11.36 \%$ & 11.226 & 12.173 \\
\hline 949.56 & 33201.17 & 2481.90 & 10850.08 & 27989.62 \\
\hline .912 & 7.682 & 4.557. & 7.180 & 9.115 \\
\hline 643.71 & 54797.38 & 5897.14 & 21809.17 & 45026.84 \\
\hline .723. & 12.678 & 10.827 & 14.432. & 14.663. \\
\hline 476.43 & $6370 \% .39$ & 6565.47 & 26646.73 & 55735.99 \\
\hline 239 & 14.740 & 12.054. & 17.633. & 18.150 \\
\hline
\end{tabular}

$4752.12 \quad 12815.29$

2.761


Steer 48
95096.50

ASH.

$5382.35 \quad 5278.04$

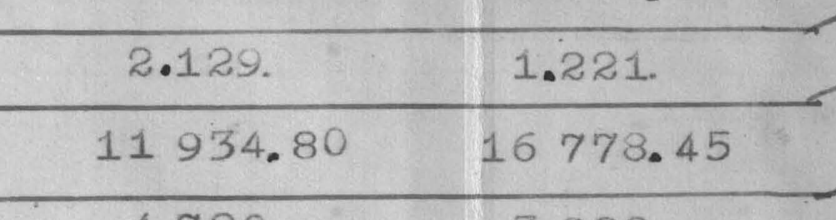

\subsection{0 \\ $\begin{array}{ll}2303.94 & 4662.56\end{array}$}

.911.

1.078

1669.24

$\begin{array}{ll}.660 & 5548.63 \\ 1.284\end{array}$

224.67

$\frac{.089}{13222.22}$

235.06
.054

12478.00

\begin{tabular}{l|l}
2225.87 & 2471.85
\end{tabular}

\begin{tabular}{ll|l}
\multicolumn{1}{c}{.880} & .572 \\
\hline 5 & 257.15 & 358.90 \\
\hline
\end{tabular}

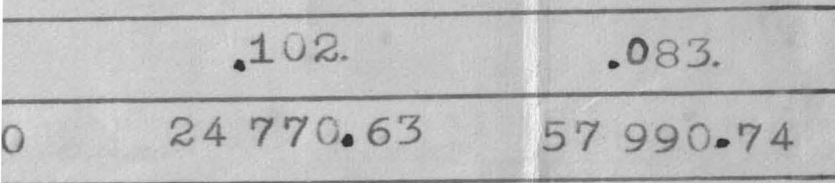

9.796

\begin{tabular}{|l|l|}
\hline 2945.92 & 16524.41 \\
\hline
\end{tabular}

2.747 .

3.823.

\begin{tabular}{l|l}
46704.08 & 56833.1
\end{tabular}

$18.470 . \quad 13.149$

6

\begin{tabular}{l|l|l|l|l|l|}
\hline 3.761 & 1.901 .665 \\
\hline
\end{tabular}

\begin{tabular}{l|l|l}
26269.83 & 42137.88
\end{tabular}

\begin{tabular}{l|l|l}
10.389 & 9.749
\end{tabular}

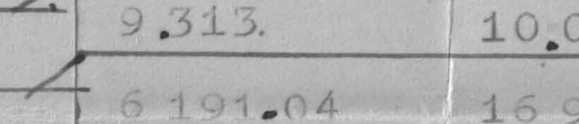

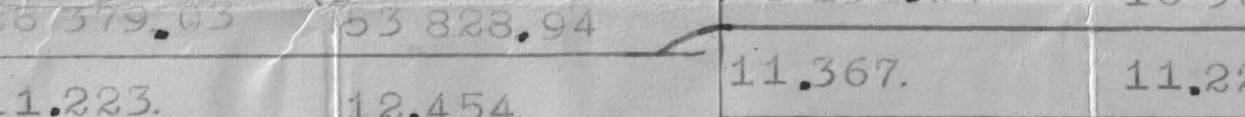

\begin{tabular}{l|l|l}
\hline 5.912 & 7.682 & $4.55 \%$
\end{tabular}

5897.

\begin{tabular}{r|r}
10850 \\
7.180
\end{tabular}

\begin{tabular}{c|c|c}
\hline 50.08 & 27989.62 & 2645. \\
\hline
\end{tabular}

\begin{tabular}{l|l}
29643.71 & 54797.38
\end{tabular}

\begin{tabular}{l|l|l|}
11.723. & 12.678. & 10.827. \\
\hline 33476.43 & 63707.39 & 656.47
\end{tabular}

21809.17

9.115

4.790

14.432 .14 .663

8.806.

3326.00

17.633 .18 .150

13.239.

$\begin{array}{ll}63707.39 & -6565.47 \\ 4.740 & 12.054\end{array}$

\begin{tabular}{l|l}
\hline 8.150. & 6.022.
\end{tabular}

$\begin{array}{ll}326.00 & 6717.44 \\ .022 & 8.508\end{array}$ 4970.5

$438-116$

$1341.75 \quad 29.53$

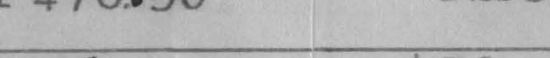

1.553.

197.27

703.38

$56.50 \quad 2.93$
.93 82.2

.270

.017

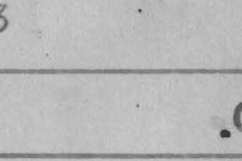

$\begin{array}{lr}16.337 & 88.029 \\ 3475.94 & 93.33\end{array}$

37.143

18.395.

$4.293 . \quad 3.655 \quad 337.82$ 13442.2 .015

7.8 年

Steer I2

PHOSPHORUS.

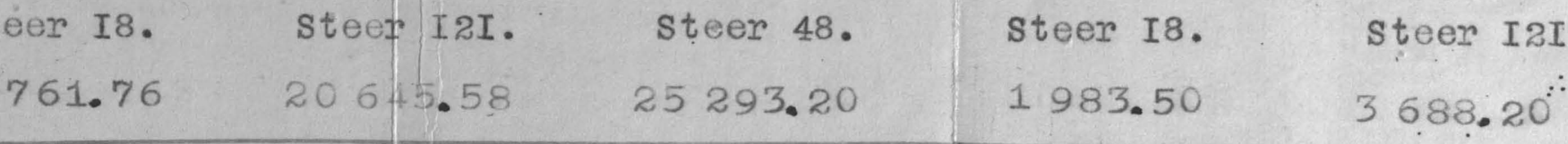

$\begin{array}{llll}5059.50-107.32 & 0.59 & 198.66\end{array}$

$3.43 \quad 6.84$

$.173 . \quad .186$

$\begin{array}{llll}13656.19 & 222.85 & 234.84 & 492.73\end{array}$

$17.46=16.61$

$.880 \quad .450$

$\begin{array}{rrrr}416.47 & 1.330 & 1.0 .89 & \\ .48 & .45 & 27.58\end{array}$

.144

.109

$3.19, \ldots .41$

$.161 . \quad 120-16$

$\begin{array}{rrr}.47 & 7.87 & 12.83\end{array}$

$\begin{array}{lll}.024 & .213 \\ 3.05 & .282\end{array}$

$\begin{array}{lll}3.05 & 2.80 & 3.29\end{array}$

$.154 . \quad .076$

$33.55 \quad 77.87$

.072.

$\begin{array}{lll}.691 . & 2.111 & 1.792\end{array}$

12

$\begin{array}{llll}5.377 & 2.043 . & 1.7 & .35 \\ 1.476 .50 & 1.561 .\end{array}$

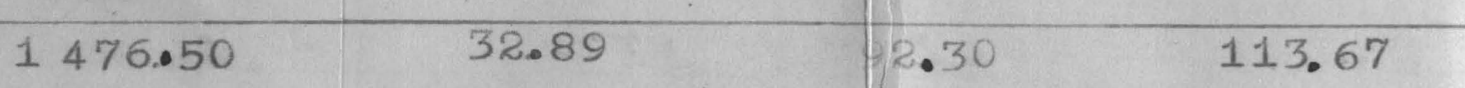
.449 .

.010 .4

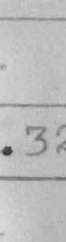

$.1\}^{2}$
.0
.0

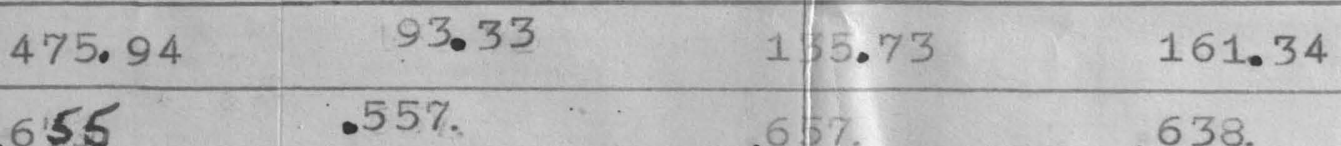

.657.

$4 \% 8.58 \quad .638$

$\begin{array}{ll}4.3 .58 & 641.76 \\ 2.3 .8 .538 .\end{array}$ $\begin{array}{lll}.411 . & .673 . & .552\end{array}$

$\begin{array}{ccc}1.61 & 2.51 & 2.44 \\ .081 & .068 & .054\end{array}$

$\begin{array}{lll}1.54 & 6.02 & 7.42\end{array}$

$.078 . \quad .166$

$.51 \quad .87$

163

$\begin{array}{lll}.026 . & .024 & .8 .75 \\ .679 .35 & 3190.74 & .060\end{array}$

$\begin{array}{lll}167 \% .35 & 3190.74 & 394 \% .01\end{array}$

$84.565 . \quad 86.512$

8.829

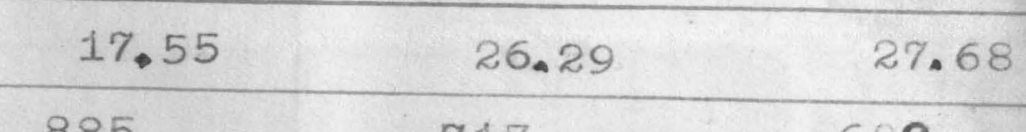

$\begin{array}{lll}.885 . & .713 & .609\end{array}$

$\begin{array}{lll}65.81 & 94.44 & 116.78\end{array}$

3.318. 2.561. 2.569

$\begin{array}{rrr}67.77 & 98.63 & 131.55 \\ 3.417 .9\end{array}$

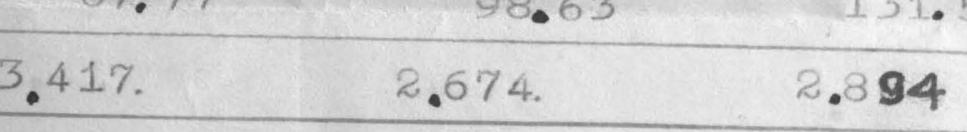

$\begin{array}{llll}5.935 & 2.148, & 2.32 & 3.547 .\end{array}$

\begin{tabular}{llll|lll}
\hline .797 .24 & 112.96 & $1 \% 5.10$ & 242.42 & 22.15 & .34 .51 & 42.05 \\
\hline 5.045 .5 & .674. & .9 & .958. & 1.117. & .936. & .925.
\end{tabular}

42.05

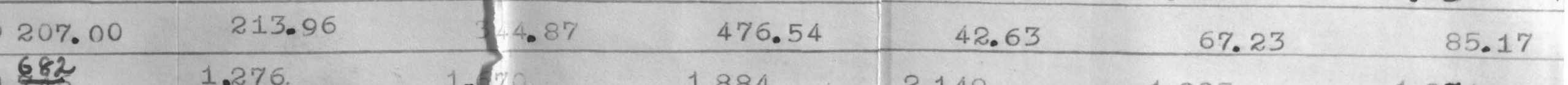

\begin{tabular}{ccc|c|ccc}
9.682 & 1.276. & 1.0 & 1.884. & 2.149. & 1.823. & 1.874. \\
\hline
\end{tabular}

$31 \quad 383.97$

27.04

$53.0^{\prime 2}$

58.37

1.518.

1.363.

1.439 .

1.284 


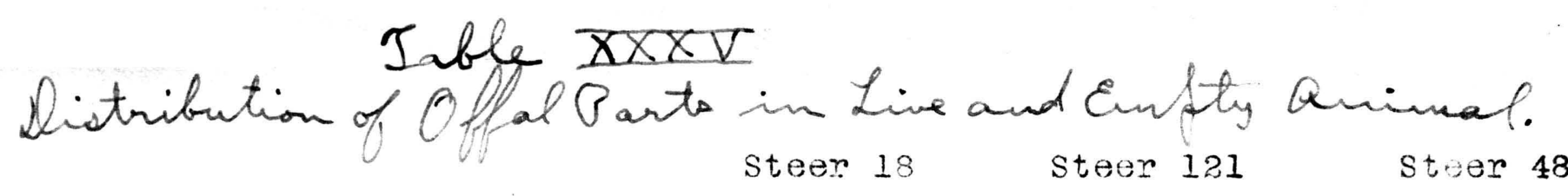

Live weight at slaughtering, pounds. 755.500

Live weight at slaughtering, kilos. 342.687.

Enoty warm weight at slaughtering,1 bs $\mathbf{6 6 6 . 1 9 3 .}$

Empty warn weight at slaughtering,k. 302.183.

of empty weight to live weight.

88.180

in weight carcass cooled 48 hours, 1bs. 447.040 .

Weight carcass cooled 48 hours, kilos.202.773.

$\%$ carcass to live weight.

59.171.

$\%$ carcass to empty weight.

67.103.

Weight hide and hair, pounds.

56.605 .

Weight hide and hair, kilos.

\% hide and hair to live weight.

io hide and hair to empty weight.

Weight offal fat, pounds.

Weight offal fat, kilos.

\&offal fat to live weight.

fo offal rat to empty weight.

Weight of blood, kilos.

$\%$ blood to live weight.

of blood to emoty weight.

weight of heart lean, kilos.

of heart lean to live weight.

\% heart lean to empty weight.

Weight respiratory system, kilos

$\%$ respiratory systern to live weight.

\% respiratory system to empty weight.

Weight of stomach, kilos.

\% stomach to live weight.

of stomach to empty weight.

Weight of intestines, kilos.

$\%$ intestines to live weight.

of intestines to empty weight.

25.674.

7.492

8.496.

12.566 .

5.700

1.886.

15.599.

4.552.

5.162 .

1.496.

3.079

1.019.

7.645 .

2.231.

2.530

6.099

1.780 .

2.018 .

Length of intestines, feet.

Length intestines per 100\# live weight.

Length intestines per 100\# empty weight.

Weight of liver, kilos.

2.625

of liver to live weight.

\% liver to empty weight.

Weight gall bladder \& gall, kilos.

of gall to live weight.

$\%$ gall to empty weight.

Weight of spleen, kilos.

\% spleen to live weight.

$\%$ spleen to empty weight.

Weight of pancreas, kilos.

\%o pancreas to live weight.

of pancreas to empty weight.
$1.66 \mathrm{~s}$

.436.

.495 .

.898 .

$\begin{array}{rr}1255.490 & 1784.970 \\ 569.469 & 809.645 \\ 1121.469 . & 1641.783 . \\ 508.513 . & 744.708 . \\ 89.296 . & 91.980 \\ 762.500 & 143.720 \\ 345.862 . & 518.780 \\ 60.734 & 64.075 \\ 68.014 . & 69.661 . \\ 65.870 & 90.750 \\ 29.876 . & 41.164 . \\ 5.246 . & 5.084 . \\ 5.875 . & 5.528 .\end{array}$

$60.352 . \quad 136.326$

$2 \% .376 . \quad 61.837$

4.807 .7 .638

$5.386 . \quad 8.304$

$24.433 . \quad 25.634$

$4.290 \quad 3.166$

$4805 . \quad 3.442$

1.596 .1 .700

$.280 \quad .210$

$.314 . \quad .228$

$4.631 . \quad 10.970$

.813 .1 .355

$.911 . \quad 1.473$

14.253. 14.113

2.503 .1 .743

2.803. $\quad 1.895$

$9.967 . \quad 7.090$

$1.750 \quad .876$

1.960 .952

$188.000 . \quad 184.300$

$14.974 . \quad 10.325$

$16.766 . \quad 11.222$

$7.035 . \quad 8.166$.

$1.235 . \quad 1.009$.

1.383 .1 .097$.

$.485 . \quad .576$.

$.085 . \quad .071$.

.095 .077

.031

.489 .

.922

1.020

.126 .

.137.

.162

.247.

.181 .

.419.

$.29 \%$

.037.

.040 


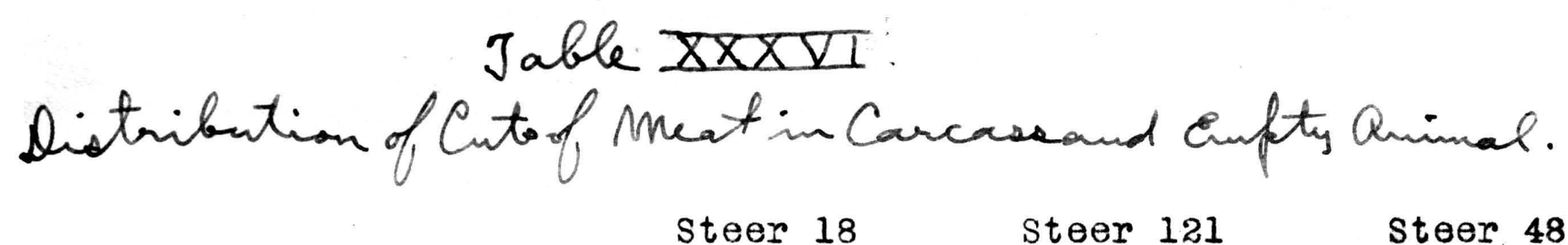

Live weight at slaughtering, kilos. 342.687.

Bnpty warm weight at slaughtering,k.302.183.

Carcass cooled, kilos.

202.773.

Weight of forequarters, kilos.

Welght of forequarters, pounds.

a\% forequarters to live weight.

\% forequarters to empty weight.

\% forequarters to carcass.

Weight hindquarters, kilos.

Weight hindquarters, pounds.

of hindquarters to live weight.

$\%$ hindquarters to empty weight.

of hindquarters to oarcass.

Weight of shins.

fo of shins to empty weight.

$\%$ of shins to carcass.

welght of plates, kilos.

\% plates to empty weight.

of plates to carcass.

Weight of chucks, kilos.

\% chucks to empty weight.

\% chucks to carcass.

* Necks see below

weight of ribs, kilos.

\&o ribs to empty weight.

\% ribs to carcass.

Teight of shanks kilos.

of shanks to empty weight.

\% shanks to carcass.

Welght of rounds, kilos.

$\%$ rounds to empty weight.

कo rounds to carcass.

weight of rumps, kilos.

\% rumps to empty weight.

\% rumps to carcass.

Weight of loins, kilos.

\% loins to empty weight.

of loins to carcass.

Feight of flanks, kilos.

of flanks to empty weight.

\% flanks to carcass.

107.954.

238.000 .

31.502

35.725 .

53.239.

94.822 .

209.040.

27.670

31.379.

46.763.

10,432

3.452 .

5.145 .

22.226.

7.355.

10.961.

53.296.

17.637.

26.284.

$18,824$.

6.229.

9.283.

8.052.

2.665 .

3.971.

38.556 .

12.759.

19.014.

7.030

$2,326$.

3.467 .

33.112.

10.958 .

16.330

4.894.

1.620 .

2.414.

Weight kidney fat \& kidneys, k110s. 3.178 .

\% kidney fat \& kid. to empty weight. 1.052.

\% kidney fat \& kidney to carcass. 1.567.

Weight of necks, kilos.

3.176 .

1.051 .

1.566 .

\% neoks to carcass.
569.469.

809.645

$508,513$.

744.708.

345,862 .

518.780 .

271.162.

597.800 .

33.491.

36.412 .

52.288.

247.632 .

545.920 .

30.585.

33.252

47.734.

15,946

2.141 .

3.074.

72.846

9.782

14.040 .

118.840 .

15,958

22,908

58,698 .

7,882

11,315

11,558

1.551.

2.228

76.488

10,271 .

14744

19.618 .

2634

3.782

96.006

12.892

18,506 .

25.528.

3.428 .

4.921.

18.398.

2.470 .

3.546 .

4.836.

.649 .

.932

.710

1.044 .

1.646 .

2.420 .

3.612. 


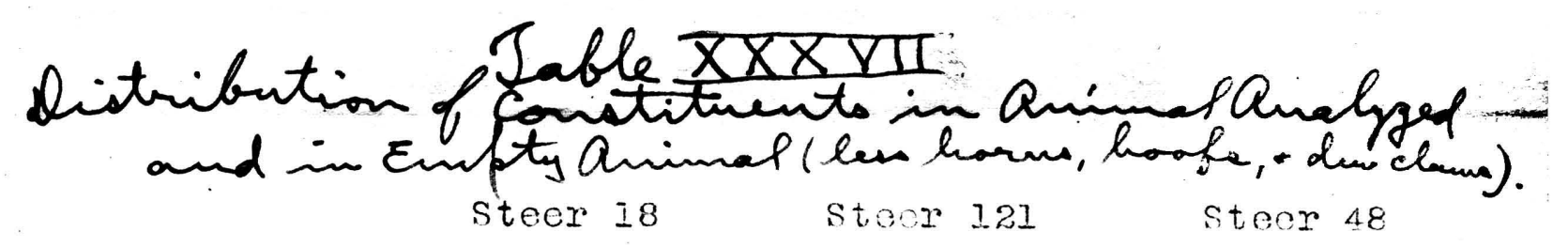

Warm empty weight of animal, kilos.

\begin{abstract}
302.183
\end{abstract}
292.996.

2.028.

295.024

7.159

2.369 $\mathbf{s}$ Empty animal analyzedless

horn, hoofs teeth \& d.c.k. 300.155 . Woight of moisture determined.

Weight of moisture

165.255

7.159

Total weight moisture in

warm empty an. analyzed. $\mathrm{k}^{\mathrm{n}} 172.414$. o total moisturo i

empty animal (less horns,etc) $5 \% .450$. \% moisture in animal

analyzed.

$\%$ dry subst.(Iess horms, et)

mpty animal.

jo dry substance to an-

imal analyzed. Welght of protein in animal analyzed.

$\%$ protein to empty an-

imal less horns ote. $\%$ protein to aninal analyzed.

Weight of fat in antmal analyzed.

$\%$ fat to empty a.rimal

less horns etc.

\% fat to animal analyzed.

Weight of ash in animal analyzed.

$\%$ ash to empty animal

less horns etc.

of ash to animal analyzod.

Weight of phosphorus $i_{n}$ animal analyzed.

$\%$ phosphorus in empty anImal Iess horns etc.

\% phosphorus in animal

42.550

43.598 .

55.231.

1.8 .101

18.850

54.465 .

18.146

18.589

16.7 .62

5.584

$5.7 R 1$

1.984 .

.661 .

.677 . analyzed.

Weighs of carcass (built

up) kilog.

$-4.087$

\subsection{3}

744.708

492.903.

2.036

494.939 .

13.574.

2.669 .

506.477

840045 .

13.574.

25.3 .619$.

50.075.

48.700

49.925.

51.300

78.951.

15.588

16.019.

151.116.

29.837.

30.658 .

20.646.

4.076.

4.189.

3.688 .

.728.

.748 .

341.650

569.469

66.391.

11.658.

13.056.

50.534 .

14.791.

201.376.

198.002

35.362

39.601.

57,955 .

94.278 .

93.114

16.555 .

18.540

27.254
721.284.

$$
2.387
$$

723.671.

21.037.

2.825.

742.321.

293.064.

21.037.

314.101.

42.312

40.407 .

57.688 .

59.593.

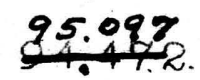

12.

13.113

307.082

41.366.

42.340.

25.293.

3.407.

3.487 .

4.546

.612

.627.

516.464.

809.645.

79.232.

9.786 .

10.638 .

62,110

$12,026$.

246.362 .

243.174 .

30.428

33.082

47.084.

212,590

211.180 .

26.257

28.547.

40.890 . fat) to empty wgt. (hand sep). 8.326 .

$\%$ fat (hand sep.) of car- $12.35 \%$

cass to wgt. of carcass. 12.357. 


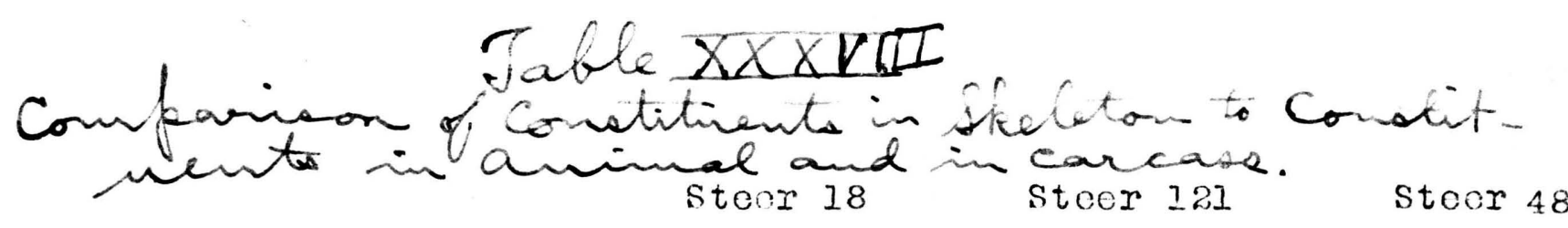

Woight of moisture in animal Grand total.

$$
172.414
$$

Weight of moisture in skoleton.

of of moisture in skeleton.

co moisture of skeleton to moisture in animal.

Weight of dry substance in

animal, grznd total.

Weight of ary substance in skeleton.

\% of dry substanco in skeleton. $c$ dry substance of skeleton to ary substance in animal.

$\approx$ Woight of fat in Animal.

$\underset{\infty}{\infty}$ Weight of fat in skeioton.

of fat in skeleton.

c of fat of skeleton to fat

in animal.

Weight of protein in animal.

Weight of protein in skoleton.

of of protein in skeleton.

$\%$ of protein of skeleton to protein of animal.

Weight of ash of animal.

Weight of ash of skeleton

of of ash skeloton. animai.

127.741.

Weight of phosphorus of animal.

Weight of phosphorus of skeleton.

o, of phosphorus in skeletion.

to phosphorus in animal

Weight of moisture in carcass. Weight of moisture in skeleton of cacosas. carcass.

moisture in carcass

Weight of dry substance in

carcass.

Weight of dry substance in skeleton of carcass.

$\%$ of dry substance in skeleton

of carcass.

$\%$ of dry substance of carcass skel.

to dry substance in carcass.

Weight of fat in carcass.

skel.

Weight of fat in carcass skeleton. 11.160.

of of fat in carcass skeleton.

$\%$ of fat of carcass skeleton

to fat in carcass.

Woight of protein in carcass.

Weight of protein in carcass skeleton.

of protein in carcass skeleton.

\% protoin of carcass skeleton

to protein in carcass.

Weight of ash in carcass.

Weight of ash in skeleton.

of of ash in skeleton.

$\%$ of ash of carcass skeleton to ash of carcass.

Weight of phosphorus in carcass.

Weight of prosphorus in carcass skeleton.

\% of phosphorus in carcass

skeleton.

\% phosphorus of carcass skeleton to phosphorus of carcass.
16.483.

28.292 .

9.560

41.778.

71.708.

32.705.

54.465.

14.724.

25.272 .

27.034.

55.231.

11.004.

18.888 .

19.924.

16.762.

14.755

25.326.

88.026 .

1.984.

1.677.

2.879

84.526 .

25.272

27.549

36.687 .

8.341 .

18.888 .

22.736.

12.419 .

11.184.

25.326.

90.055 .

1.510

1.271.

2.879

253.619

19.687.

29.653.

7.762.

252.858 .

46.704 .

70.347.

18.470

151.116.

14.065.

21.185.

9.308 .

78.951 .

14.523.

21.875 .

18.395.

20.646 .

17.907

27.108.

87.169.

3.688 .

3.191.

4.806.

86.524 .

514.101.

2.2.3. $=5$

20.270

1.131.

432.220

50.835.

71.730

$13.14 \%$

$367.08 \%$

$16.80 \%$

21.206.

5.472

95.027

15.536 .

19.606

$1 \div 331$

25.293.

21.210

26.769 .

83.857 .

4.589 .

3.947 .

4.982 .

86.010

161.166

199.932

14.985 .

29.653.

16.055 .

25.850

$9.298 . \quad 8.030$

180.484 . $\quad 316.532$.

$35.549 . \quad 46.055$.

$70.347 . \quad 74.150$

$19.696 . \quad 14.550$

$111.536 . \quad 229.087$.

$10.706 . \quad 14.830$

$21.185 . \quad 2 \div .861$.

9.599 . $\quad 6.474$.

52.811 .

11.054 . $11.86 \%$

21.875 . $\quad 19.106$.

20.931 18.48

$15.572 . \quad 19.800$

$13.699 . \quad 17.013$.

27.108. 27.392

$87.972 . \quad 85.924$.

2.797. $\quad 3.611$.

2.429. $\quad 3.153$.

$4.806 . \quad 5.077$

84.172

86.843

87.317 


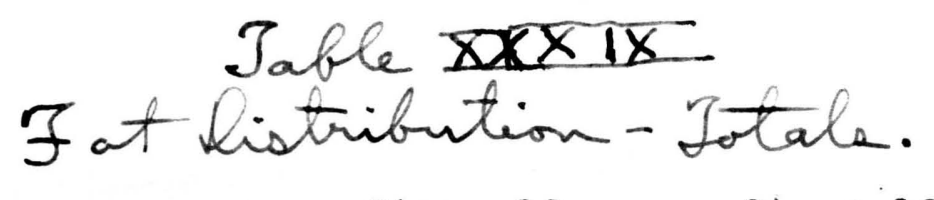

Steer 18

Steer 121

Steer 48

Total weight of analytic-

$\widehat{\mathrm{w}}_{\mathrm{v}}$ fat.

al fat in Animal. ,

weight of fat in

skeleton. 2

fat. 3

Weight of fat in offal

fat. 4

Weight of fat in kidney

Sum of fat in skeleton,

offal \& kidney fat. $5(2+3+4)$

Fat in flesh \& internal

organs of animal.6 (1-5)

weight of fat in offal

fat. 7

Weight of fat in kidney

8 Sum of fat in offal \&

kidney fat. $(2+\&)$ ?

Weight of fat in lean

of animal.10

Weight of fat in fat of

carcass + head \& tail.ll

54.465.

$14.72,4$

4.544 .

$2.12,5$

21.393.

33.072

4.544 .

2.125

6.669.

2.2 .974

6.811 .

Fat in lean \& fat of an-

imal (lesscuntemal organd+ K. F. 29.785.

fat. 1

Weight of fat in kidney

2.125.

Weight of fat in lean \&

fat flesh(less kidney fat).14(12-1) 27.660 $\%$ fat in entire animal

analyzed. 15

18.589.

\% fat in skeleton.16

\% fat in flesh \& internal

organs to fat in animal.17 $\frac{6}{1}$

25.272 .

60.722

10 fat in offal z kidney

fat to fat of animal./8 $9 /$

\% fat in offal \& kidney

fat to bal. fat in animal.14 $\frac{\pi}{21}$

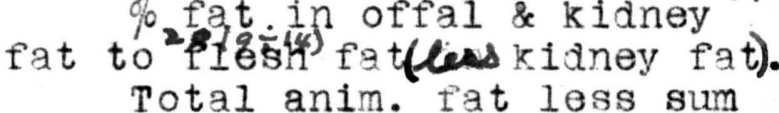
of offal \& kidney fat.2/ (1-9) of flesh fatlless kidney fat) to total fat.22 $\frac{14}{1}$

total fat. $23 \frac{2}{3}$ fot of adipose tissue (exclioffal fationd kiduey fat)

Total animal lean.

Total animal fat loss

offal fat.

Total fleshy part of animal

Kidney fat.

2.444

Lean \& adipose tissue

of an. (excl. kidney \&offal fat. 157.094.
151.116.

14.065

24.095

6.884.

56.946

$16.26 \%$

45.044.

90.10

106.072

$217.0 \%$

24.095.

56.946

6.884

16.262

30.979.

73.206.

43.058

74.184

58.597.

141.152

101.655

215.336

6.884

16.262

94.771.

199.074.

30.658

42.340.

21.185

21.206

70.198

70.689

23.840

25.786 .

31.302

32.688 .

36.774.

$20.13 \%$

233.874.

62.714.

64.828.

$9.30 \%$

5.472

38.776

45.966

201.376.

94.278

246.362 .

212.590

295.654.

7.272

458.952 .

17.170

288.382.

441.782 . 
Steer No.

Productive Grain consumed During Full Fed Porlod, Pounds.

Productive Corn Consumed (8/9ths of Grain)

Digestible Protein in

ProductIv corn, Pounds.

Energy in Productive Corn, Inerms.

\section{Produotive IInseed don-} sumed (I/9th of Grain)

\section{Digestible Protein in Productive Linseed.} จ

$\omega \stackrel{1}{\omega}$

$\omega \stackrel{w}{w}$ Energy in Productive

$\dot{0} \infty$ Linseed, Therms.

N

A $G$

त)

i.

$\rightarrow$

Productive Alfalfa

Consumed, Potunds.
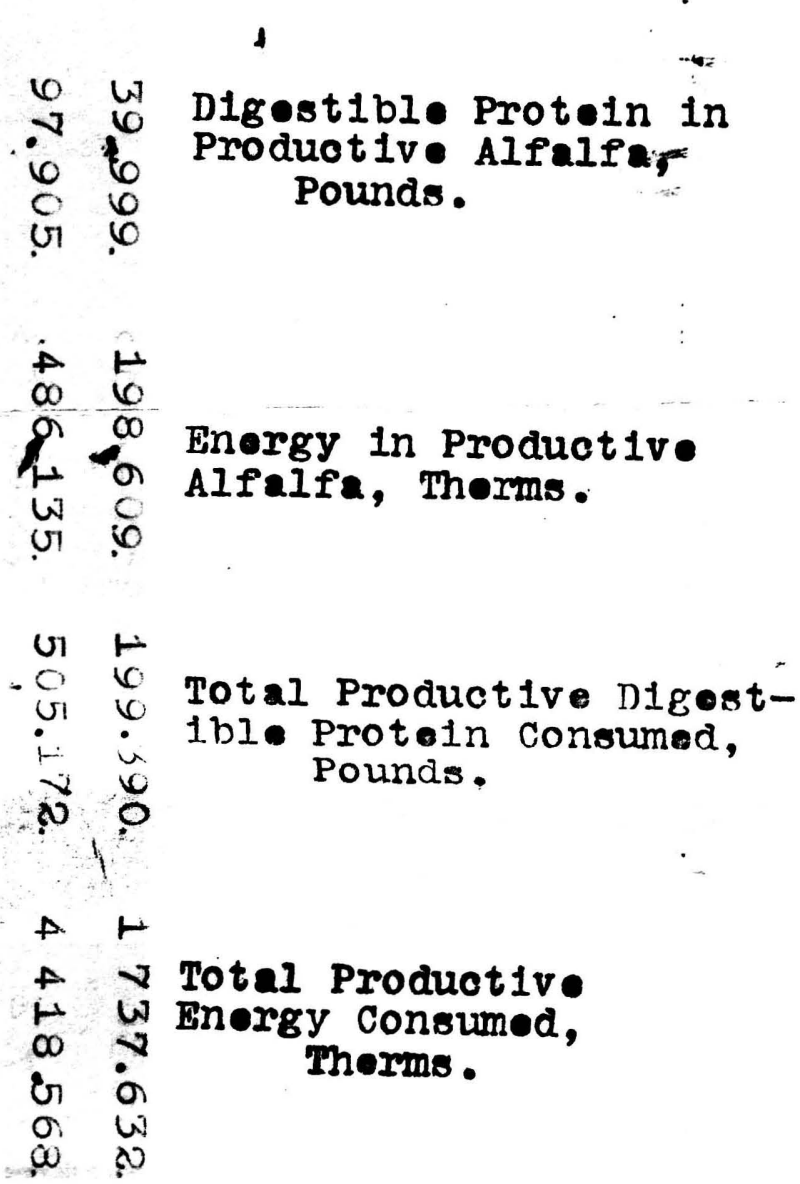

N) $($ Total Productive Digest-

- 0 lble Protaln Conmumar,

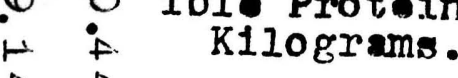

steor No.

H. Average Walght at End

$\checkmark$ N of Full Fed Poriod.

$\checkmark F$ Pounds.

o $\omega$

$G H$

$g$ w Longth of Perlod Days.

( Total Grain Consumed.

C C During Period.

i Pounds.

vi

1

c Maintenance Require-

mont in Grain for

Period.

Pounds.

\section{Total Productive}

Grain for Porlod.

Pounds.

(2) i

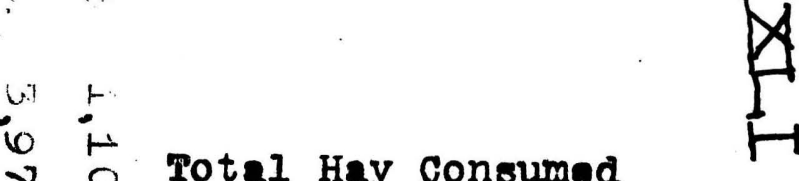

จ. O Total Hay Consumad

$o$ w During Perlod, Pounds.

a 19$$
\text { G }
$$

iv Hay Required for

Maintonance, Pounds

a

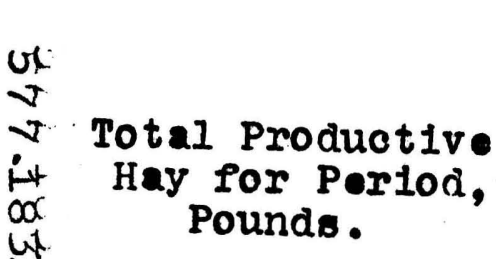

Total Productive Pounds.

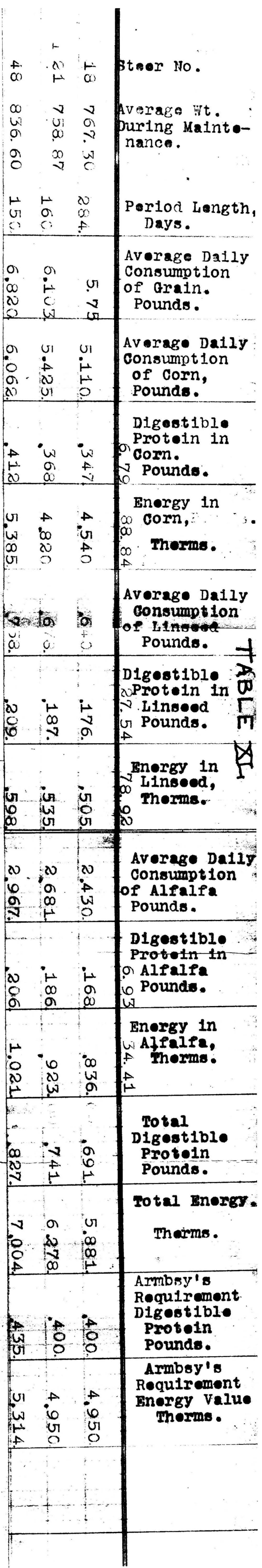


Welght in Steer I8 Weight in steer I2I Excess in Steer I2I

Total W/t. in Feed

Wt. In Feed above Maintenance

Productive(Digestible)

In Steor I8

(1ght in 3I.434 Ibs. additional of stonr I 1036.6 ibs

Velght in Steor 48

Excoss in steer 48

Wit. In Feed above

Total Wt. In Foe

Productive(Digestible)
4.

165.25

240.045 .

74.790

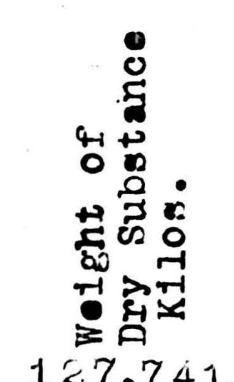

252.353

125.117

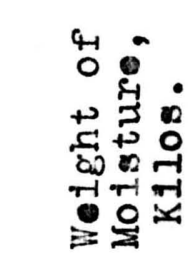

165255

17.730

182.985

293.064.

110.079.

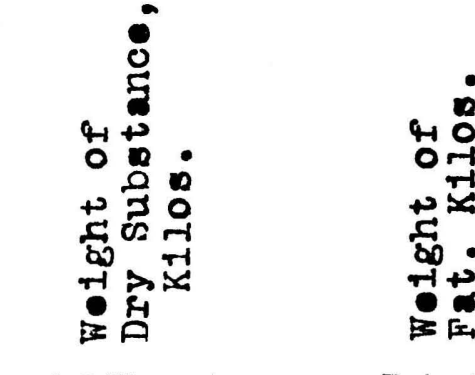

127.741 .

$13.7 \cup 4$.

141.445 .

432.220.

290.775

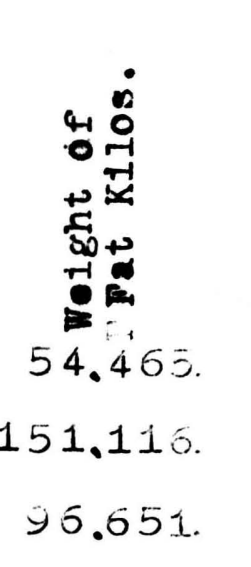

मे

(131

7.951

2.720

6.130

$21.334 . \quad+\begin{gathered}\text { n1trogen } \\ \text { fren } \\ \text { extract } \\ 61.515 .\end{gathered}$

40.05\% 13415 .

$=.0411$

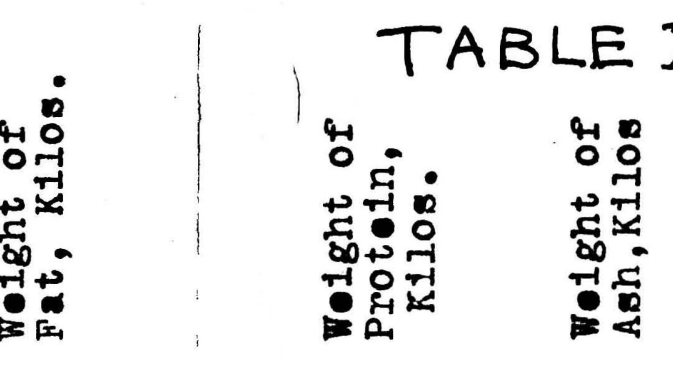

5.843.

$60.30 \%$

$307.08 \%$

246.774 .

85.48y.

$204.1 \cup 1$.

4⿻

$3.927 . \quad 1.785$.

1.150. 18.420 .

$5.097 \quad 25.293$.

.939
$*$ trogen $\begin{array}{ll}\text { N.trogen } & \text { Crude } \\ \text { freo } & \text { fibro. }\end{array}$

3.tract $9.274 .+561.621$.

$7: 7.322 .5683 .857$.
TABLE XIIII

这苟

16.762.

20.646 .

3.884.

1.704. frude.

199.326.

107.994.

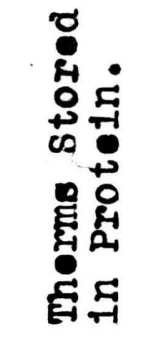

$+054.781$

569.469

344.216

225.253

1737.632.

$z 0.141$.

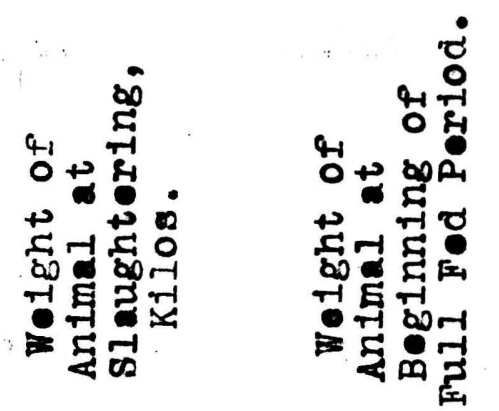

$\dot{艹}$

क E

.213.

2.197.

4.546

2.349 .192 .264

299.100.

743.239. 